\title{
السياسة الجنائية المعاصره فى هواجهة التنظيمات الإرهابية
}

\author{
shel \\ أ.د / شيماء عبد الغنى محمد عطا الله \\ أستاذ مساعد القانون الجنائى \\ كليت الحقوق - جامعت الزقازيق
}


أ.د/ شيماء عبد الغنى محمد عطا الله

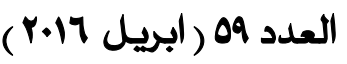

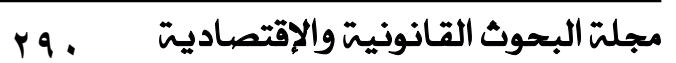




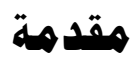

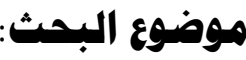

يتناول هذا البحث موضوعا من الموضوعات الحديثة والذي يشكل مظهرا من

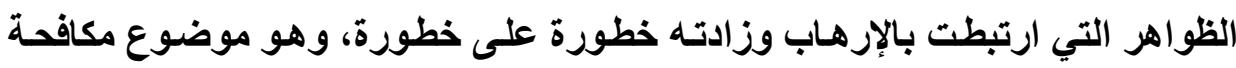

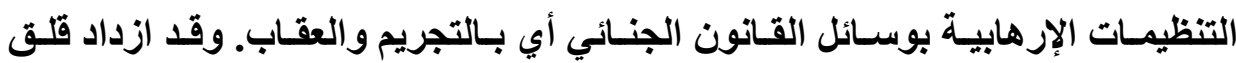

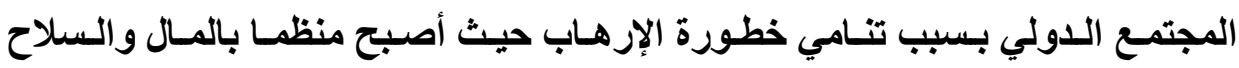

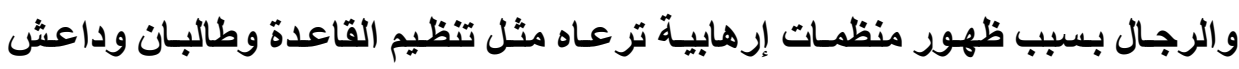
وغيرها من عشرات التنظيمات الإرهابية. كما ازدادت خطورتها بسبب ارتباطها بالداين واستغلالها جهل كثير من الشباب فانضموا إليها عارضين أنفسهم للمسوت بأحزمسة ناسفة وعزاؤهم في ذلك أنهم داخلون الجنة لا محالة.

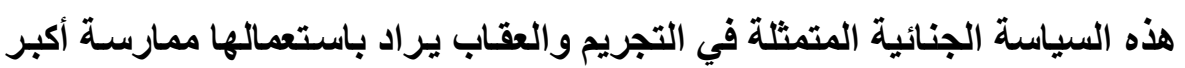

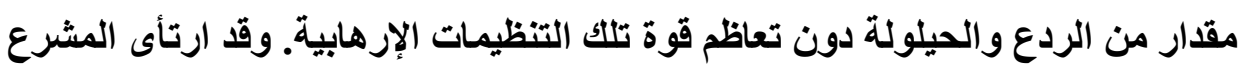

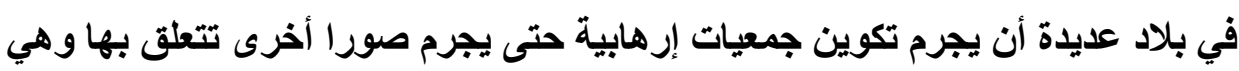

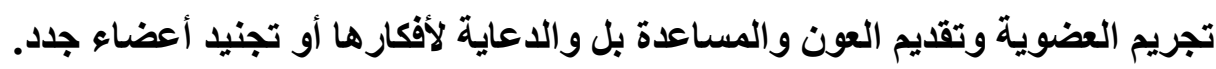
وقد ارتبط بالسياسة الجنائية المعاصرة في مواجهة ظاهرة التنظيمات الإرهابية

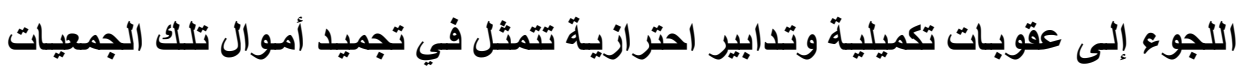

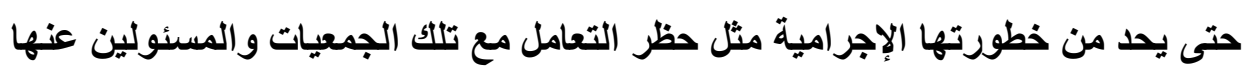

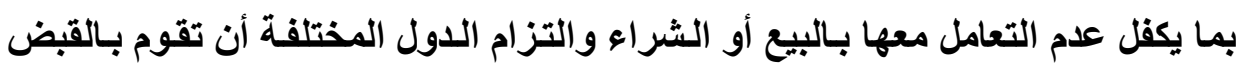
على أعضائها و المسئولين عنها. 


\section{أهميهة البحث:}

ترجع أهمية البحث إلى الأحداث الأخيرة التي هزت العالم منذ أعمال الإرهاب التي

كاتت وراء هجمـات الحسادي عشر من سبتمبر سنة ا ل. . ب في أمريكا على يل تنظيم القاعدة وقيـام الولايـات المتحدة الأمريكية مـع حلفائهـا بغزو أفغانستـان معقل تنظيم القاعدة الإرهابي. ولم يقف الأمر عند ذلك فقد ظهرت عشرات التظظيمات الإرهابية وخاصـة تنظيم داعش وهجومهـا على عدة دول منهـا سـوريا ومسر وفرنسا وليبيـا وغيرها باستخدام الأحزمة الناسفة والانتحاريين لإيقاع أكبر مقدار من الضحايا من بين المدنيين.

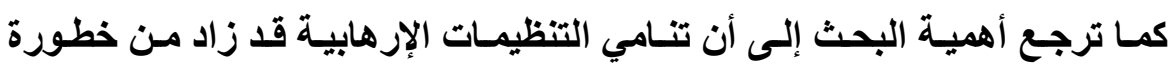
الإرهاب. فلم يعد الإرهابي يعمل بمفرده، بل يحتاج إلى سلاح وإلى تمويل، وإلى تدريب وتنظيم ينتمي إليه ويعوله ماليا وعائليا ويوفر لله الحياة والراتب بل والزواج. وقبل ذلك يحتاج الإرهابي إلى فتاوى وأيدولوجيات تسوغ وتبرر القيام بأثشنع العمليات الإرهابية باسم الدين. فيقدم الإرهابي بفضل تلكك الفتاوى على تفجير نفسه بحزام ناسف فيقتل نفسه ويقتل غيره بأعداد كبيرة وهو بهذا يتقرب إلى الله وهو على ثقة من أنه سوف يإخل الجنة وينعم بنعيمها. وترجع أهمية الموضوع من الناحية القانونية إلى أن مواجهة التنظيمات الإرهابية باستخدام سلاح القانون الجنائي قد أثنار مشكلات قانونية تتعلق بمدى احترام حقوق الإنسـان. ذلك أن الدول المختلفة تستخدم طريقتين في مكافحـة التظظيمـات الإرهابيـة. أولى تلك الطرق أن تستعمل الدولـة أدوات القـانون الجنـائي في مكافحة التنظيمـات الإرهابية، وثانية تلك الطرق أن تستعمل الدولة حالة الطوارئ التي تخرج عن الأدوات التقليدية في القانون الجنائي في مكافحة تلكك الظاهرة. 
في الحالة الأولى كما في الحالة الثانية تثار مشكلات قانونية دقيقة بخصوص القو اعد التقليديـة فـي قـانون العقوبـات والخاصـة بمبـدأ شـرعية الجرائم والعقوبـات وضرورة ارتكاب الفعل الإجرامي لأن القانون الجنائي لا يعاقب على مجرد النوايا، كما تتعلق بعدم العقاب على الأعمال التحضيرية وكذلك بوجوب احترام الحقى في التعبير والحق في الحياة الخاصة وغيرهـا من المبادئ القانونيـة التي تشكل أعمدة القانون

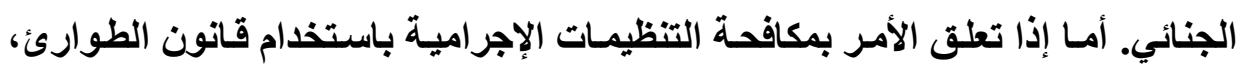

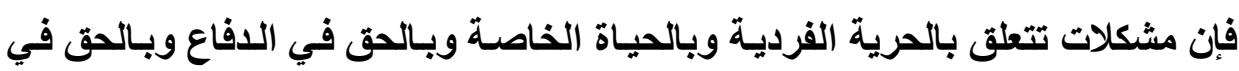

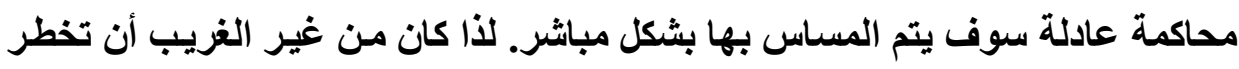

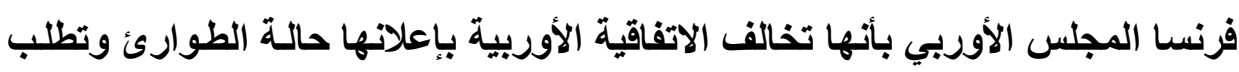
السماح لها بذلك بثكل مؤقت بسبب مكافحة الإرهاب على أراضيها على إثر الهجمـات التي خطط لها ونفذها تنظيم داعش الإرهابي.

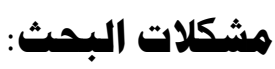
يثير هذا البحث عدة مشكلات قانونية سوف يهدف إلى بيـان أبعادها في القانون

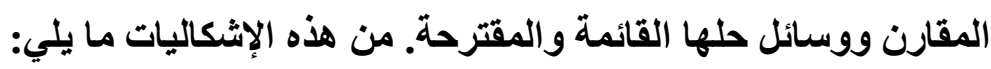

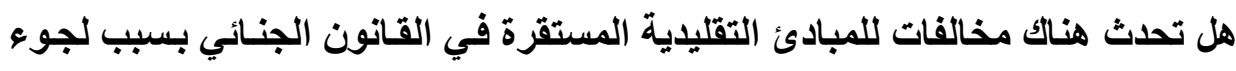

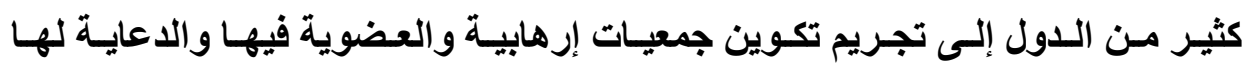

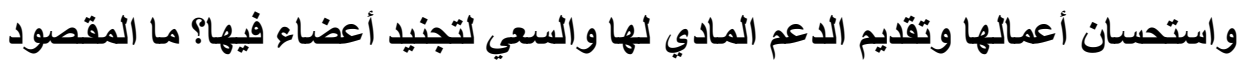

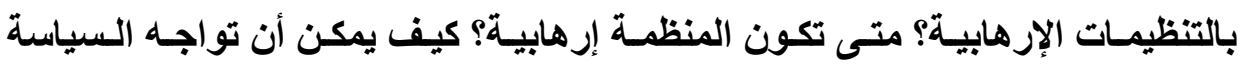

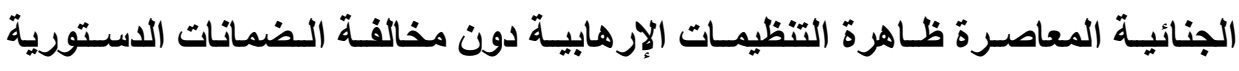

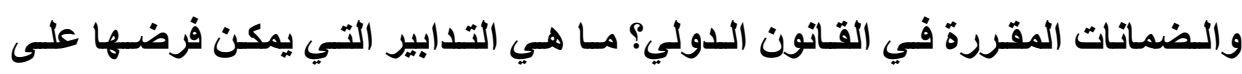

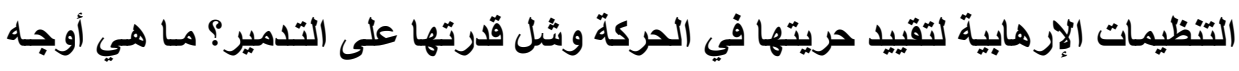
التعاون الاولي في مجال مكافحة التنظيمات الإرهابية؟ 
يعتمد هذا البحث في مضمونه على منهج تحليلي تأصيلي مقارن. فهو تحليلي يفسر ويناقش ويعرض القضايا ويخلص إلى النتائج، وهو تأصيلي حيث يرد الفروع

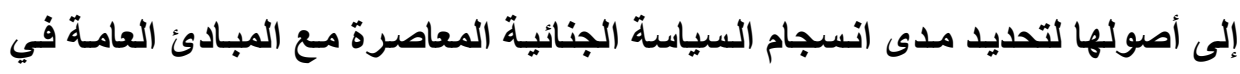
القانون الجنائي كمبأ قرينة البراءة حيث لا يلتزم المتهم بتقديم دليل براعتهه، ومبادئ أخرى مستقرة في القانون الجنائي كاحترام الحرية الفردية والحياة الخاصة والحق في

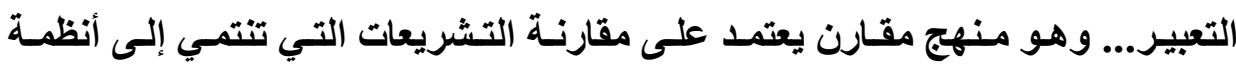
قانونية ذات الأصل اللاتيني وتلك التي تنتمي إلى القوانين ذات الأصل الأنجلوأمريكي.

$$
\text { يعتمد البحث على خطة تتكون من فصلين: }
$$

الفصل الأول: نعـالج فيـه التعريـف بـالتظيم الإرهـابي وآليـات تعديـات المنظمـات

$$
\text { الإرهابية }
$$

أما الفصل الثاني: فقد خصصناه لاراسة النتائج القانونية لاعتبار التنظيم إرهابياً 


\section{الفصل الأول \\ التهريف بالمنظمة الإرهابية في ظل السياسة الجنائية \\ المعاصرة وآلية تحديدها}

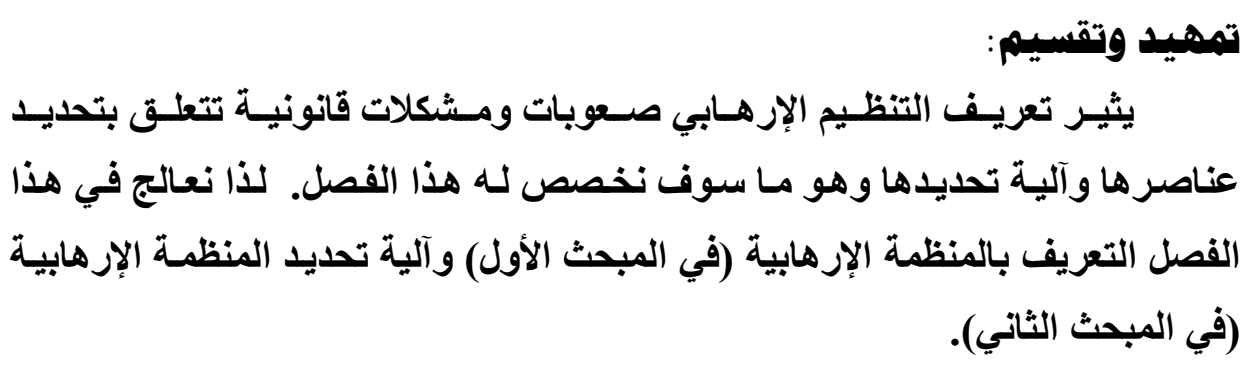

المبحث الأول

التعريف بالمنظيمة الإرهابية

في ظل السياسة الجنائية المعاصرة

للتعريف بالمنظمة الإرهابية يتعين تحديد مفهومها والخصائص المميزة لتلك التظظيمات (في المطلب الأول) وبيان كيف أن هذا المفهوم أصبح واسعا بسبب التوسـع في مفهوم الجريمة الإرهابية (وهو ما نتناوله في المطلب الثاني).

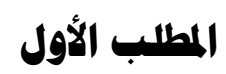

هفهوم التنظيم الإرهابي والخصائص المميزة له

\section{الاقصود بالتنظيم الإرهابي:}

لـم تستقر التشريعات المقارنـة على تعريف موحد للتنظيمـات الإرهابيـة. بـل إن

المشرع المـصري قد غـاير في تعريفـه لتلك التنظيمـات بين القرار بقانون الكيانـات

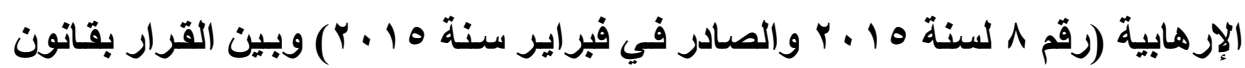

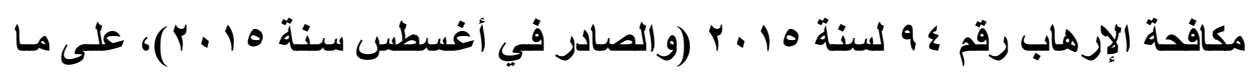
سيلي بيانه؛ 


\section{أولاً - هفهوم التنظيم الإرهابي وفقا لقانون الكيانات الإرهابية في هصر:}

تضمن القرار بقانون رقم 1 لسنة 1 ـ ـ ب، في شـأن تنظيم الكيانـات الإرهابية والإرهابيين في مصر الذي ينص في مادته الأولى على تعريف الكيان الإرهابي بقولهن:

"الكيان الإرهابي، يقصد به الجمعيات أو المنظمات أو الجماعات أو العصابات

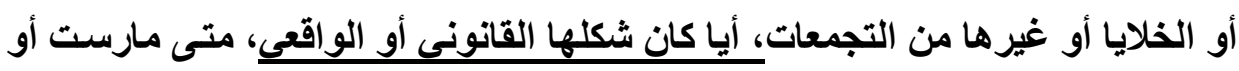

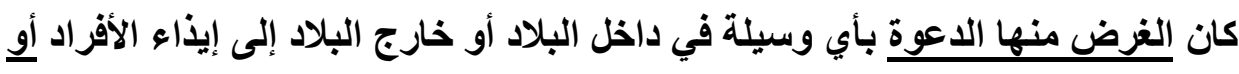

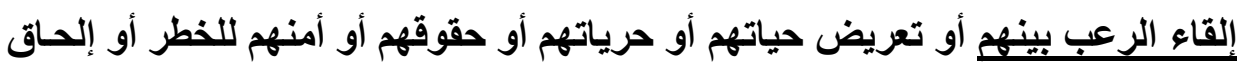

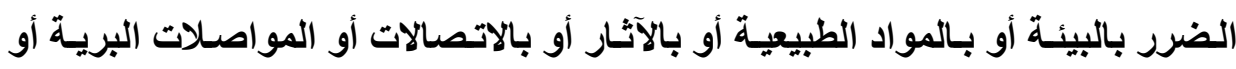

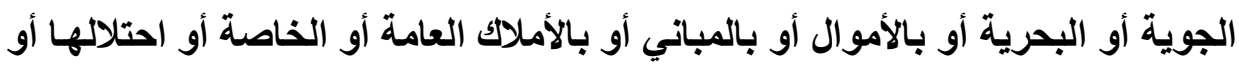

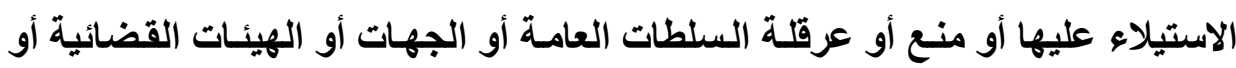

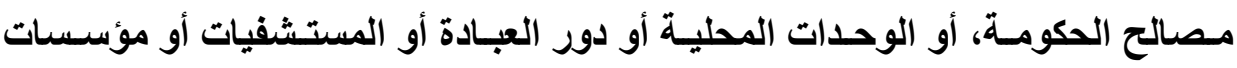

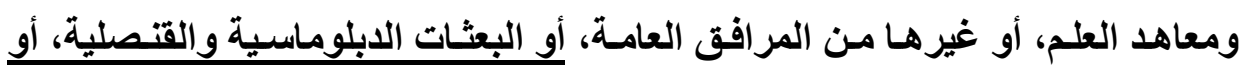

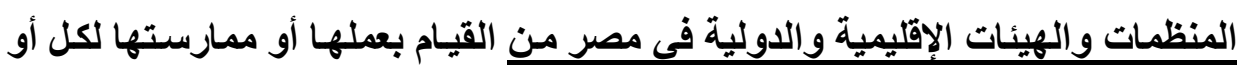

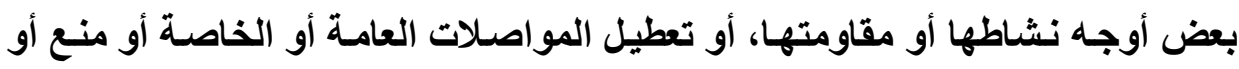

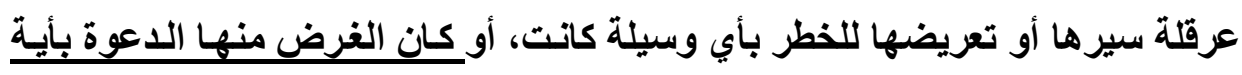

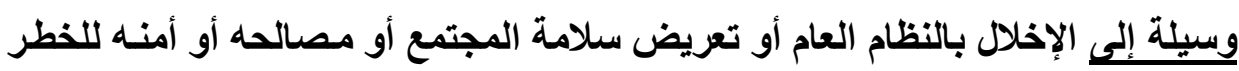
أو تعطيل أحكام الاستور أو القوانين أو منع إحدى مؤسسات الدولة أو إحدى السلطات

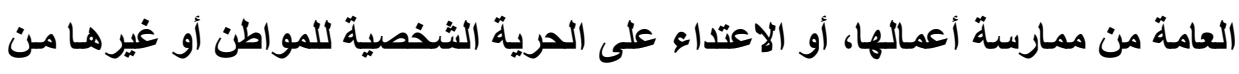

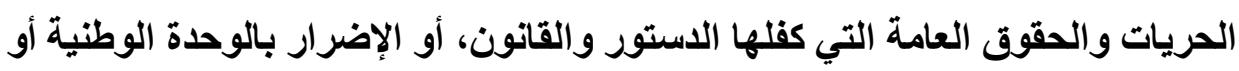

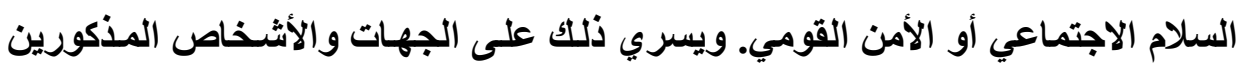

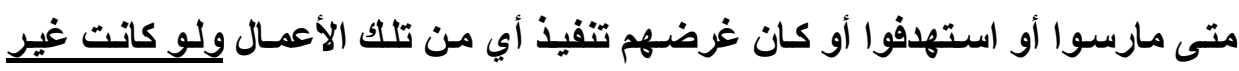
موجهة إلى جمهورية مصر العربية". 
مما سبق يتضح أن التظظيم الإرهابي وفقا للقانون المصري يتضمن العناصر

أــ التظظيم الإرهابي لا يثترط فيه شكل معين؛ فقد يتخذ شكل جمعية أو شركة وقد

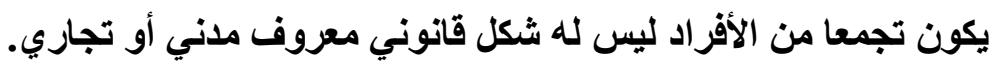

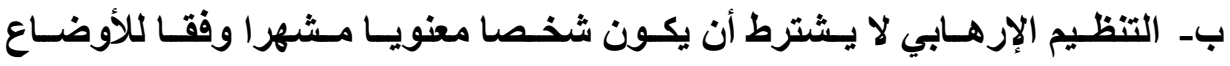
القانونية، فالتجمع من الناحية الفعلية يصلح أن يكتسب صفة التفئل التظيم الإرهابي.

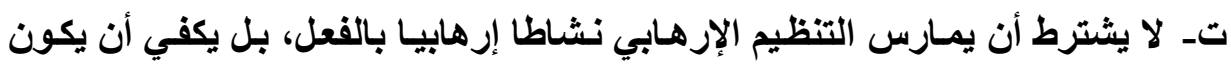

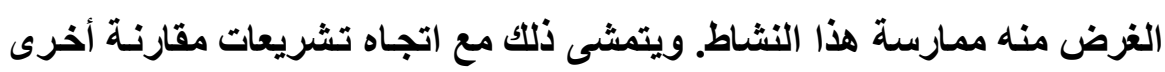

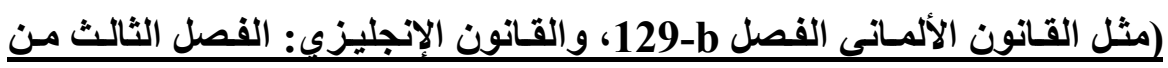

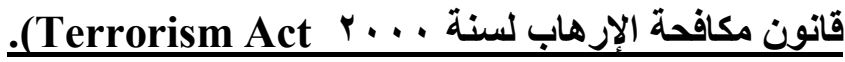

ثـ- يكفي في التنظيم لكي يكون إرهابيا أن يكون هدفه الدعوة إلى ارتكاب أفعال

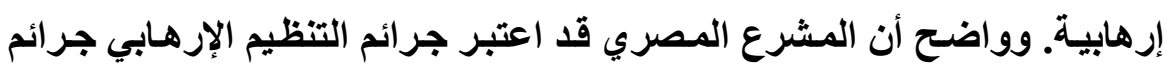

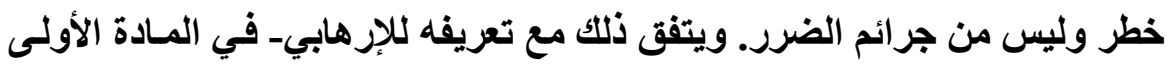

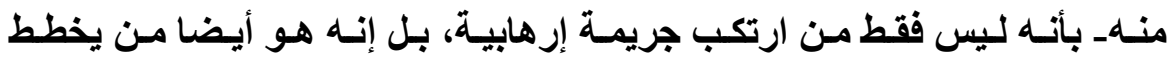

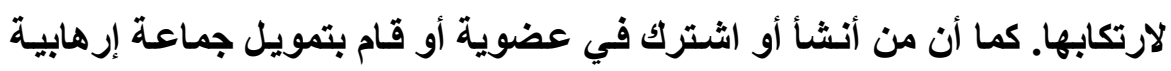

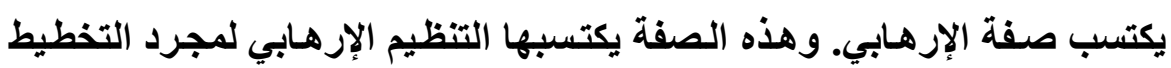
لارتكاب جريمة إرهابية. ج- لا يثترط أن يكون التنظيم محليا، فقد يكون تنظيما متواجدا في بلدا أجنبي، مـادام

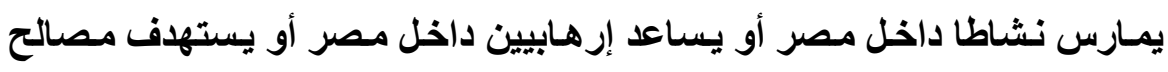

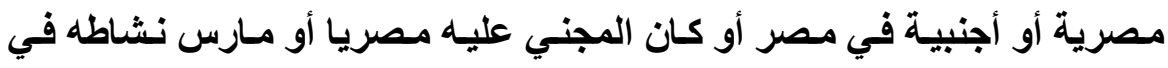

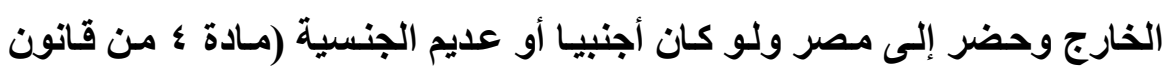

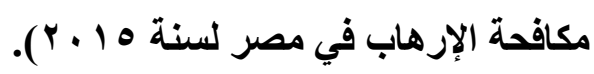


وواضح من صياغة قانون مكافحة الإرهـاب لسنة ه 1 ـ ب أنـه وسـع في مجـال

تطبيق القوانين المصرية على التظظيمات الإرهابية عما كان يتجـهـ إليه قانون الكيانـات الإرهابية. هذا الأخير كان يميل إلى تطبيق مبدأ الإقليمية بنصه في المـادة الأولى على العى أنه "ويسرى ذلك على الجهات والأشخاص المذكورين متى مارسوا أو استهذفوا أو كان غرضهم تنفيذ أي من تلك الأعمـال ولـو كانت غير موجهة إلى جمهوريـة مصر العربيـة". فالمقصود بأنهـا غيـر موجهـة إلـى جمهوريـة مـصر العربيـة أن الأعمـال الإرهابيـة يسري عليهـا قـانون الكيانـات الإرهابيـة المـصري وبقيـة قـانون العقوبـات وتختص المحاكم المصرية بمحاكمة مرتكبي تلك الأعمال إذا وقعت في جمهوريـة مصر العربيـة حتى ولـو لم تكن مصر مستهدفة بتلك الأفعـال كـأن تقع اعتـاءً على بعثـات دبلوماسية أجنبية على الأراضي المصرية. ولا يحول دون ذلكك أن المـادة الأولى من قـانون الكيانـات الإرهابيـة قد عرفت الإرهابي بأنه "كل شخص طبيعي يرتكب أو يشرع في ارتكـاب أو يحرض أو يهدد أو

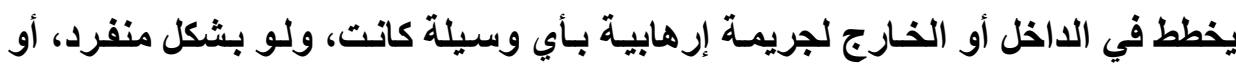
يساهم في هذه الجريمة في إطار مشروع إجرامي مشترك، أو تولى قيـادة أو زعامـة أو إدارة أو إنشاء أو تأسيس أو اشتراك في عضوية أي من الكيانات الإرهابية المنصوص عليها في المـادة رقم (1) من هذا القانون أو قام بتمويلها، أو سـاهم في نشاطها مـع علمه بذلك". ذلك أن تعبير "يهدد أو يخطط في الداخل أو الخـارج لجريمـة إرهابية"

$$
\text { يقصد به أن جريمة إرهابية تقع في مصر. }
$$

غير أن قانون مكافحة الإرهـاب وسـع في مجـال تطبيقهـ لكي يمد مجـال تطبيقهـ أبعد من مبدأ الإقليميـة ومبدأ الشخصية الإيجابية ومبدأ العلم ومبدأ جنسية الطبائرة ومبدأ العينية وهي من القواعد التقليدية إلى قواعد جديدة. من هذه القواعد الجديدة مبلأ 
الثخصية السلبية ومبدأ العالمية('). بمقتضى مبدأ الثخصية السلبية يسري قانون مكافحة الإرهاب على من يرتكب الفعل الذي يقع على مجني عليها مصري. وبمقتضى

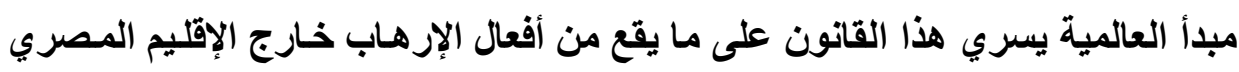
من شخص أجنبي أو عديم الأهلية إذا تواجد في مصر (المادة ؛ ).

وهذا هو الاتجاه السائد في القانون المقارن مثل القانون الأمريكي section act 219 of the Immigration and Nationality Act

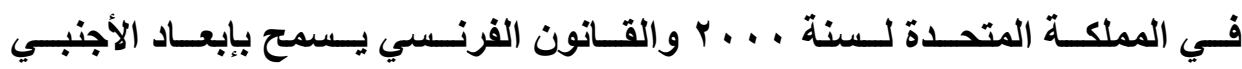
أب éloignement de l'étranger Code de وكررته المادة L.551-1 من قانون دخول وإقامـة الأجاتب وحق اللجوء .(l'entrée et du séjour des étrangers et du droit d'asile ح - يلزم أن تستهدف المنظمة الإرهابية تحقيق غرض معين. غير أن المشرع

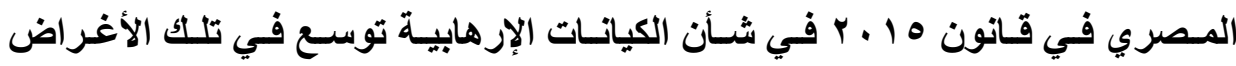
الإرهابية لتشمل استهداف التظظيم لعدة صور جديدة من النشاط الإجرامي. من تلك الصور: إيذاء الأفراد في حياتهم أو سلامتهم الجسمية أو حرياتهم ـ الإضرار بالبيئة ـ منـع إحدى مؤسسـات الدولـة أو إحدى السلطات العامـة مـن ممارسـة أعمالهـاــ تعطيل مرافق الدولـة المختلفة ـ تعطيل المواصـلات العامـة أو الخاصـةـ تعطيل عمل البعثات

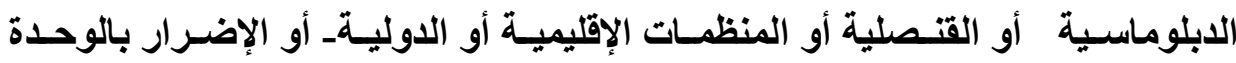
الوطنية.

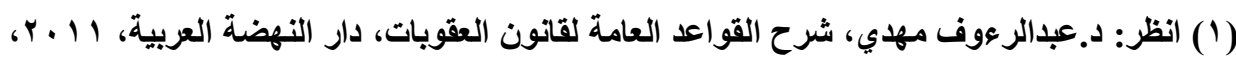

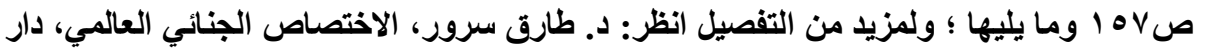

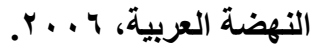


ويلاحظظ أن قـانون الكيانـات الإرهابيـة فـي تعريفـه للكيـان الإرهـابي (التنظيم

الإرهابي) قـ وقع في عيب خطير وهو أنها لم يربط الغرض من العمل الذي يدعو لـه

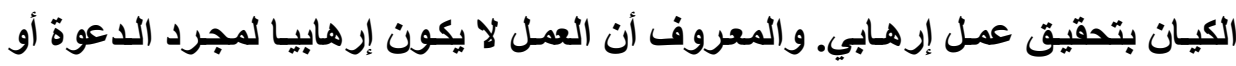

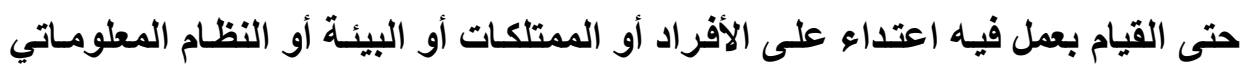
ولكنـه يلزم فيها أن يكون واقعا بقصد الترويع لتحقيق غرض أيديولوجي أو دينـي أو سياسي أو لمعاقبة السلطات على رفضها الخضوع للدعوات الإرهابية. ولهـذا نتنقد صياغة المادة السابقة التي جعلت من قصد الترويع حالة من الحالات التي يسعى الكيان

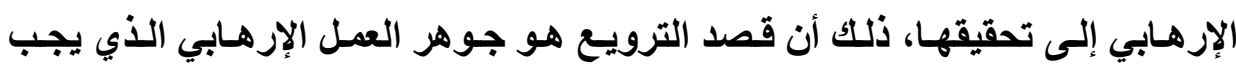
توافره في كل صورة من صور هذا العمل. كما نتتقد تعريف الجماعات الإرهابية الذي ورد في قانون العقوبـات في المـادة

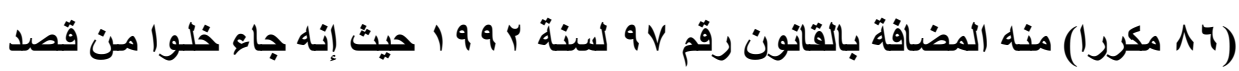

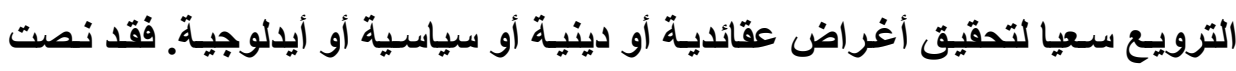

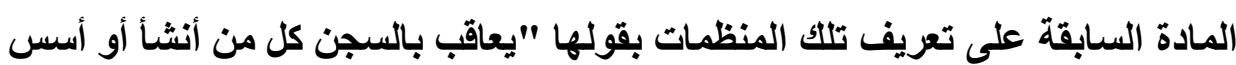

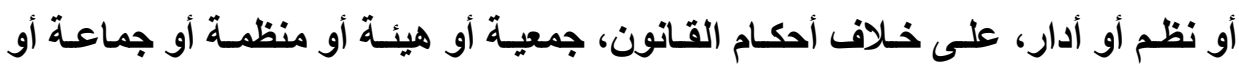
عصابة، يكون الغرض منها الدعوة بأية وسيلة إلى تعطيل أحكام الاستور أو القوانين،

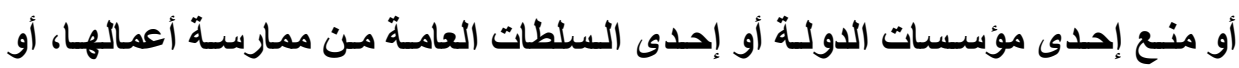
الاعتداء على الحرية الشخصية للمواطن أو غيرها من الحريـات والحقوق العامـة التي كفلها الاستور والقـانون، أو الإضرار بالوحدة الوطنية أو السلام الاجتمـاعي، ويعاقب فئه بالسجن المشدد كل من تولى زعامة أو قيادة فيها، أو أمدها بمعونات مادية أو مالية مع علمه بالغرض الأي تدعو إليه. 
ويعاقب بالسجن مدة لا تزيد على خمس سنوات كل من انضم إلى إحدى الجمعيات أو الهيئات أو المنظمات أو الجماعات أو العصابات المنصوص عليها في الفقرة السابقة، أو شارك فيها بأي صورة مع علمه بأغراضها". ومـن الخطير أن نعرف التظظيم الإرهـابي دون اشـتراط قصد الترويـع لتحقيق أغراض معينة وهو ما نطلق عليه بضرورة توافر القصد الخاص، حيث يؤدي ذلك إلى الى

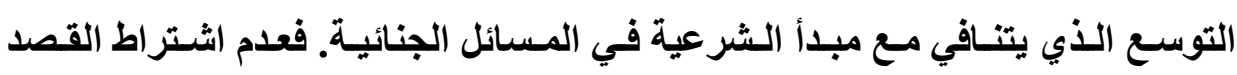
الخاص يؤدي إلى تطبيق نص التظيمـات الإرهابية على منظمي المظاهر ات، ذلك أن كثيرا من المظاهرات التي يمكن أن يسند إلى منظميها والمشاركين فيها أنهم يدعون إلى تعطيل القوانين تحقيقاً لأغراض معينة يسعون إلى تحقيقها من وراء المظاهرات. وبالمثل فإن الاعتصامات والاحتجاجات التي تقوم بها النقابـات يمكن أن يسري عليها هذا الوصف من السعي إلى عدم تطبيق الدستور أو القوانين واللوائح أو منع إحدى مؤسسات الدولة من ممارسة عملها. يُّضاف إلى ذلك مـا احتواه القـانون من خلط بين فكرة الإرهـاب وبين الإخلال بالوحدة الوطنية. فبإذا قـام شجار أو تقاتل بين منتمين إلى مسلمين وأقباط فبان الأمر ليس دائما يندرج ضمن الإرهاب. وما يميز المشاحنات الطائفية عن الإرهاب هو القصد

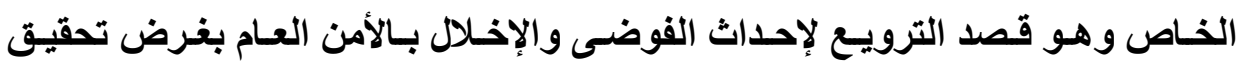
أغراض أيدولوجية معينة. فقد نصت المادة الأولى من قانون الكيانـات الإرهابية لسنة

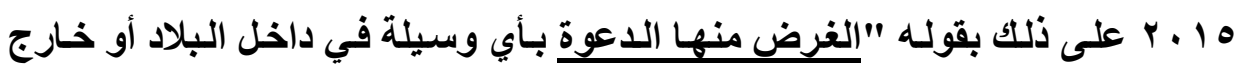
البلاد إلى إيذاء الأفراد أو إلقاء الرعب بينهـ أو...". بل إن المادة (؟^^) عقوبات عندما عرفت الإرهـاب فإنها اقتصرث على ذكر أن الأقعـال الواقعـة على الأثـخاص أو الأمسوال أو البيئـة أو ... كانـت واقعـة "مـن خـلال 
مشروع جماعي أو فردي". ولا نرى أن هذا التعبير يكفي للالالة على قصد الترويع. فبين المشروع وبين قصد الترويع فارق واضح وكبير. وفي ذات الخط، فإن المشرع لـ يكن موفقا أيضا عندما عرف الإرهابي بأنه يرتكب جريمة إرهابية دون أن يقوم بتحديد معالمها بشكل واضح. فقد نصت المادة الأولى من قانون الكيانات الإرهابية على تعريف الإرهابي بأنه "كل شخص طبيعي يرتكب أو يشرع في ارتكاب أو يحرض أو يهدد أو

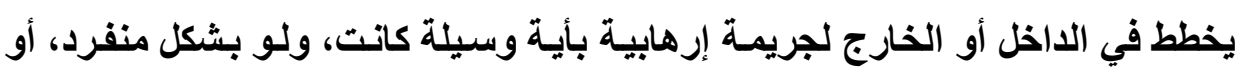

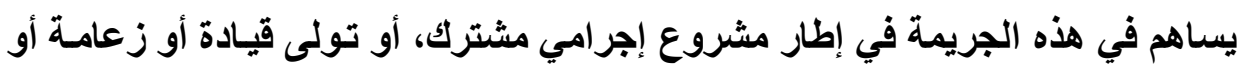

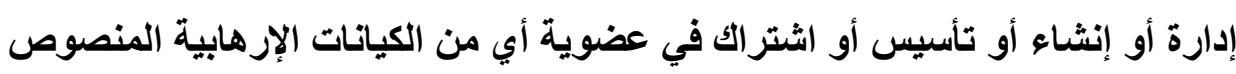

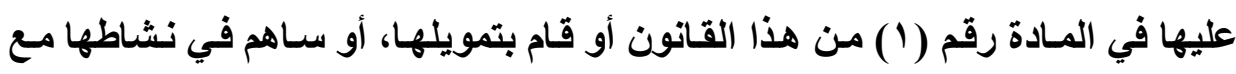
علمه بذلك.

والدليل على ذلك أن المشرع في المسادة († م) مكررا - أ عقوبـات نص على ظرف مشدد عندما يكون الإرهاب من الوسائل المستخدمة في تحقيق أو تنفيذ الأغراض

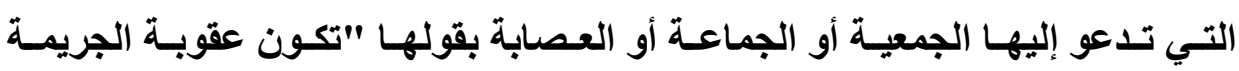
المنصوص عليها في الفقرة الأولى من المسادة السابقة الإعدام أو السجن المشدد، إذا كان الإرهاب من الوسائل التي تستخدم في تحقيق أو تنفيذ الأغراض التي تدعو إليها

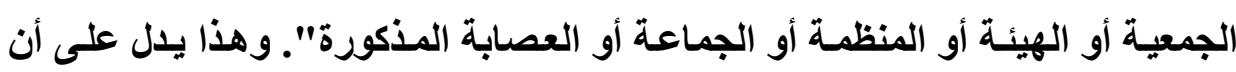
التظيم الوارد في المادة (؟^) مكررا عقوبات ليس بالضرورة تنظيما إرهابياً. ونؤكد على أن القصد الخاص هو الأي يميز بين الأعمال العنيفة التي تدخل في

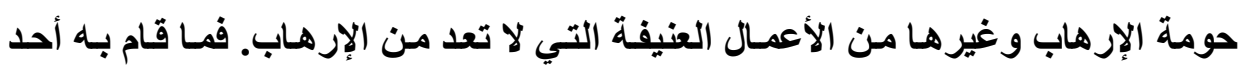
الأثخاص المسلحين من الدخول إلى إحدى المدارس وقتله عددا من التلاميذ وكـان القصد من فعله هو الانتقام لا يعد من الأعمال الإرهابية، بينما ذات الفعل لو كان بغرض الفي 
إثارة الفوضى لإظهار عجز الدولة عن تحقيق الأمن للنـاس دعوةً منـه إلى إقامـة نظـام للحكم يختلف عما هو قائم يرقى بهذا الفعل إلى مصاف الأعمال الإرهابية. وممـا يؤكد أن توافر قصد الترويـع من أركـان الجريمـة الإرهابية أن الاتفاقـات

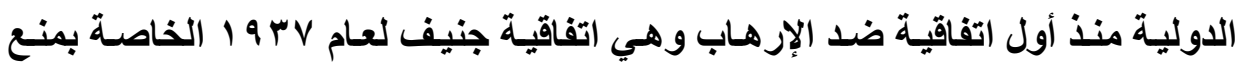

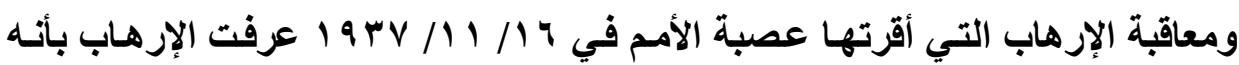
هو "الأعمال الإجرامية الموجهة ضد دولة مـا وتستهـف أو يقصد بها خلق حالة من الرعب في أذهان أشخاص معينين أو مجموعة من الأشخاص أو عامـة الجمهور" . كمـا أن الاتفاقيـة الدوليـة لقــع تمويـل الإرهـاب لسنة 999 و 9 بقرار الجمعيـة العامـة للأمـم

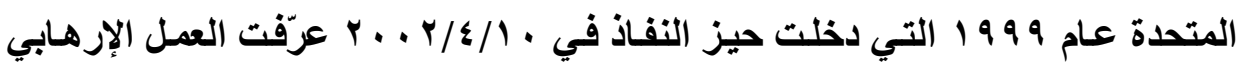
بالغرض منه وهو عندما يكون هذا الغرض بحكم طبيعته أو في سياقه موجهاً لترويع السكان، أو لإرغام حكومة أو منظمة دولية على القيام بعمل أو الامتتاع عن القيام به".

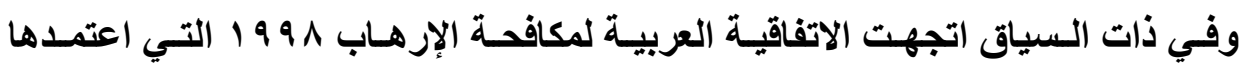

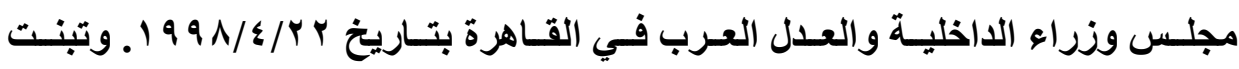

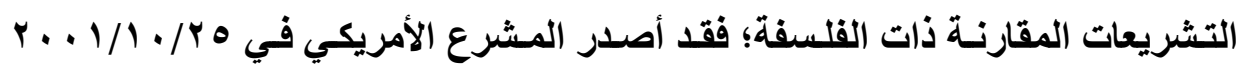
عقب أحداث 11 سبتمبر من نفس العـام قانونـاً لمقاومـة الإرهـاب وهو قـانون معدل

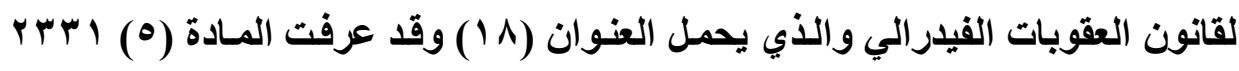
العـل الإرهـابي بأنـه يتم "بقصد تخويـف أو إجبار المـنيين، أو التـأثير على سياسـة

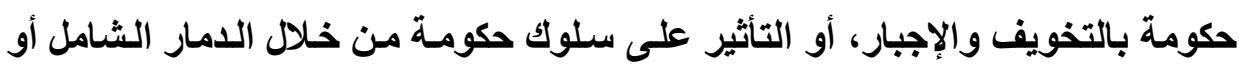
الاغتيال أو الخطف". ولم يخرج المشرع البريطاني عن هذا الإطـار؛ فقد عرفت المـادة

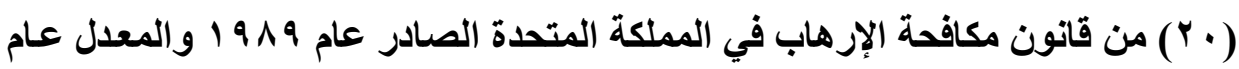

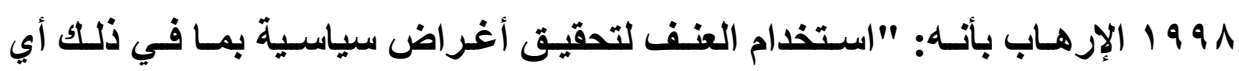
استخدام للعنف بغرض إثـاعة الخوف من أفراد الثعب أو بين قطاع منهم". ثم أصدر 
المشرع البريطاني قانوناً عام . . . . عرف فيه الإرهاب بأنه: القيام أو التهايد بالقيام لأغراض خدمة قضية سياسية أو دينية أو أيديولوجية بأعمال تنظوي على عنف شديد ضد شخص أو إلحاق الضرر بالممتلكات أو تعريض حياة شخص للخطر أو أعمال تمثل

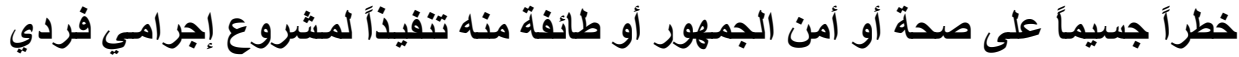
أو جماعي، ويهدف إلى إلقاء الرعب بين الناس أو ترويعهم بإيذائهم أو تعريض حياتهم أو حريـاتهم أو أمـنهم للخطر، أو إلحـاق الـضرر بالبيئة، أو بأحـد المرافق أو الأمـلاك العامـة أو الخاصـة، أو احتلالهـا أو الاستيلاء عليها، أو تعريض أحد المـوارد الوطنيـة للخطر ". وكـان قـانون العقوبـات قد سبق أن تعرض لتعريف التنظيم الإرهابي بـالتجريم

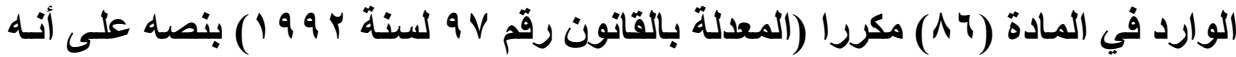
"يعاقب بالسجن كل من أنثأ أو أسس أو نظم أو أدار، على خلاف أحكام القانون جمعية

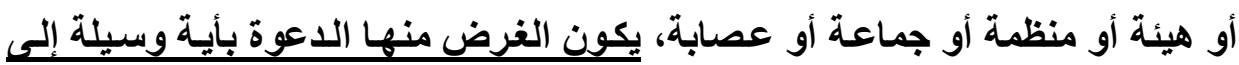
تعطيل أحكام اللستور أو القوانين، أو منع إحدى مؤسسات الدولة أو إحدى السلطات العامة من ممارسة أعمالها، أو الاعتذاء على الحرية الشخصية للمواطن أو غيرها من الحريات والحقوق العامة التي كفلها الاستور والقانون، أو الإضرار بالوحدة الوطنية أو الو الوعنه السلام الاجتماعي. ويعاقب بالسجن المشدد كل من تولى زعامـة، أو قيـادة مـا فيها، أو أمدها بمعونات مادية أو مالية مع علمه بالغرض الأي تدعو إليه. ويعاقب بالسجن مـدة لا تزيـد على خمس سـنوات كل مسن انـضم إلى إحـى الجمعيـات أو الهيئـات أو المنظمـات أو الجماعـات، أو العصابات المنصوص عليهـا في الفقرة السابقة، أو شارك فيها بأية صورة، مع علمه بأغر اضها. ويعاقب بالعقوبـة المنصوص عليها في الفقرة السابقة كل من روج بـالقول أو الكتابة أو بأية طريقة أخرى للأغراض المذكورة في الفقرة الأولى، 
وكـذلك مـن حـاز بالــات أو بالواســة أو أحـرز محـررات أو مطبوعـات أو

تسجيلات، أيا كان نوعها، تتضمن ترويجا لشيء ممـا تقدم إذا كاتت معدة للتوزيع أو لاطلاع الغير عليها، وكل من حاز أو أحرز أية وسيلة من وسـائل الطبع أو التسجيل أو لودئ

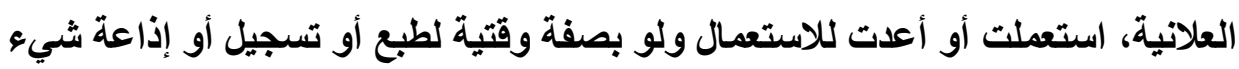

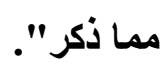

وواضح من مطالعة المـادة (૪^^) مكررا عقوبـات في تعريفة للتنظيم الإرهابي

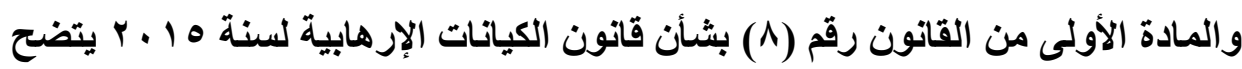
أن المادة الأخيرة لم تلغ المادة (؟ ^) مكررا على الرغم من أن كلا منهما يتناول تعريفا

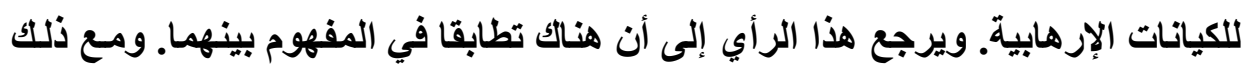
فإن المادة الأولى من قانون الكيانـات الإرهابيـة تكون واجبة التطبيق باعتبـ التبار هـا لاحقهـ على المادة (؟^) مكررا عقوبات فيما تضمنته من أحكام جديدة تتمثل في التالي: 1 - توسعت المادة الأولى من قانون الكيانـات الإرهابية في مفهوم التنظيم الإرهابي فأضافت إلى المادة († ^) مكررا عناصر إضافية يمكن أن تقع محلا لفعل الإرهـاب. من ذلك الآثار وكذلك الاتصالات أو المواصـلات البريـة أو البحريـة أو الجويـة.ولا يشترك أن تكون تلك المرافق من المرافق العامـة. وهذا يبرز جوانب للتوسع في مفهوم التظظيم الإرهابي. وبالمثل توسعت المادة الأولى عندما أشـارت إلى الأمـلاك

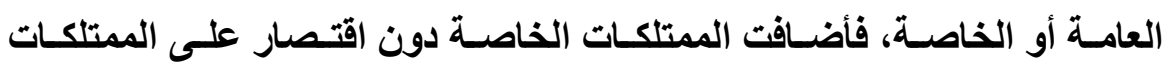
العامة. كما أضافت ذات المادة فعل "الاحتلال" بأن أضافته إلى فعل "الاستيلاء" على تلكك الممتلكات أو المرافت.

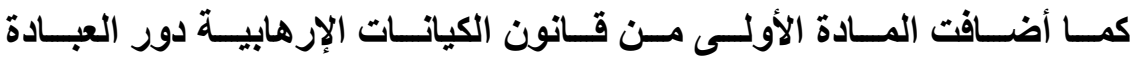
والمستثفيات ومؤسسات العلم دون اقتصار أي منها على المؤسسات والمرافق العامة. 
وبناء عليه فإن المستشفيات ومؤسسات العلم ولو كانت تنتمس إلى الجهات الخاصة

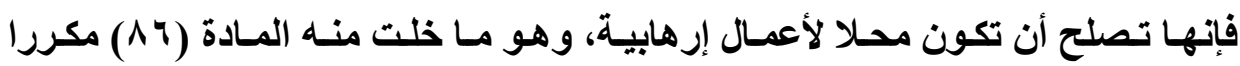
عقوبات. وفي ذات الاتجاه الموسع الذي تبنته المادة الأولى من قانون الكيانات الإرهابية، أضافت تلك المادة البعثات الابلوماسية والقنصلية والهيئات الإقليمية والدولة العامة في مصر. r- وضع قانون الكيانات الإرهابية نظاماً خاصا بقوائم التنظيمات الإرهابية لتحديد تلك التنظيمات كما وضع طرقا للطعن في الدكم الصادر بالكيـان أنه إرهابي، ولم يكن

$$
\text { ذلك موجودا في قانون العقوبات. }
$$

r- حدد قـانون الكيانـات الإرهابية النتائج القانونيـة المترتبـة على اعتبار منظمـة مـا إرهابية؛ فنص على تدابير يتم الحكم بها لمجرد توافر تلك الصفة بقوله "- حظر الكيان الإرهابي ووقف أنشطته. بـ غلق الأمكنة المخصصة له وحظر اجتماعاته.

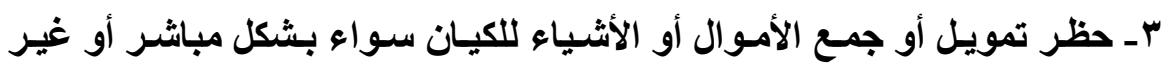
مباشر. ع ـ تجميا الأموال المملوكة للكيان، أو لأعضائه متى كانت مستخدمة في ممارسة النشاط الإرهابي. هـ حظر الانضمام للكيان أو الاعوة إلى ذلك أو الترويج لـه أو رفـع شـعار اته. وبالنسبة للإِرهـابيين، الإدراج على قوائم المنـع مـن السفر وترقب الوصول، أو منع الأجنبي من دخول البلاد- سحب جواز السفر أو إلغاؤه،

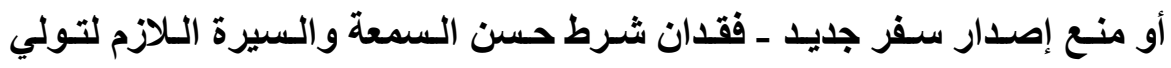
الوظائف والمناصب العامة أو النيابية ـ تجميد أموال الإرهابي متى استخدمت في ممارسة نشاطه الإرهابي". وذلك كله لم ينص عليه قانون العقوبات. 


\section{ثانياً- هفهوم التنظيم الإرهابي وفقا لقانون هكافحة الإرهاب في هصر:}

استخدم المشرع المصري في قانون مكافحة الإرهاب تعبيراً مغايراً للالالة على التى

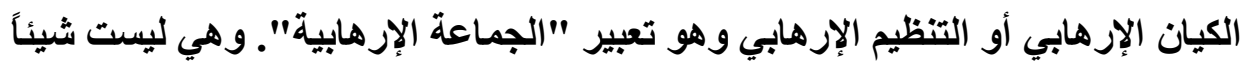
آخر الكيان الإرهابي أو التنظيم الإرهابي أو المنظمة الإرهابية.

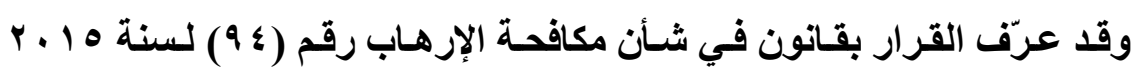

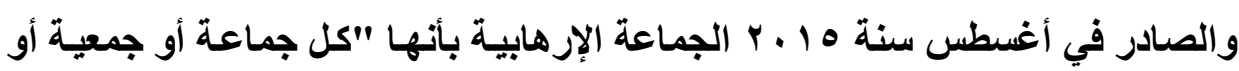

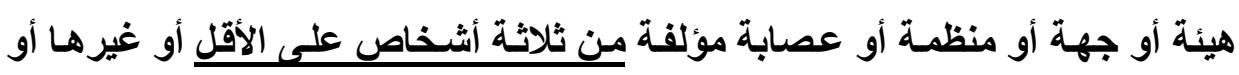

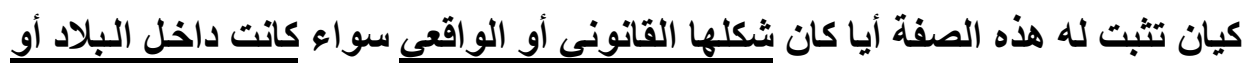

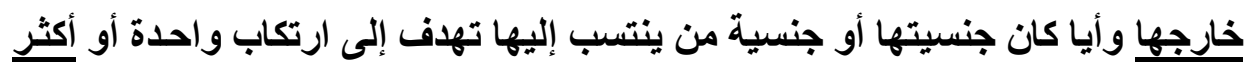

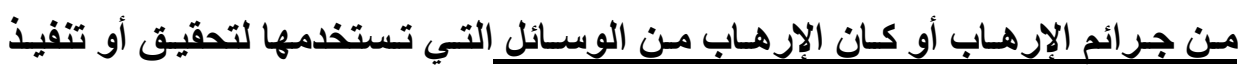

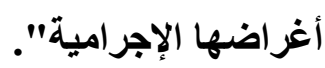

وقد غُني القانون السابق بتوضيح المقصود بالإرهاب، الأمر الذي من شـأنه أن

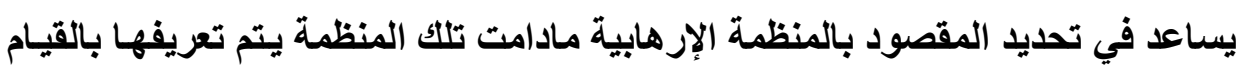

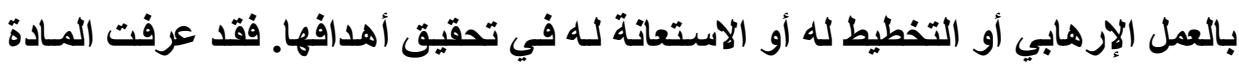

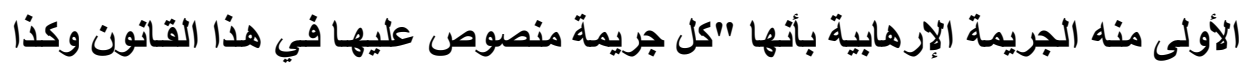

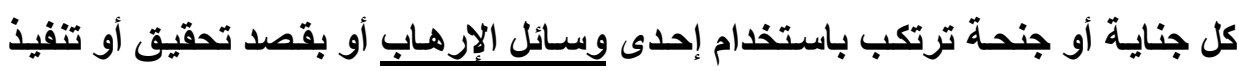

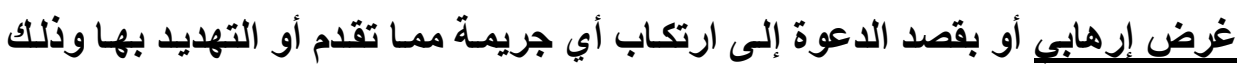

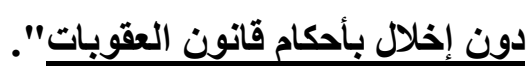

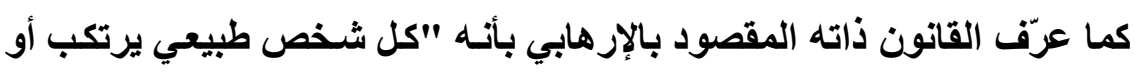

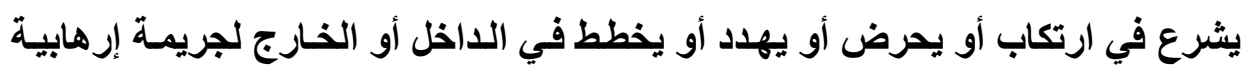

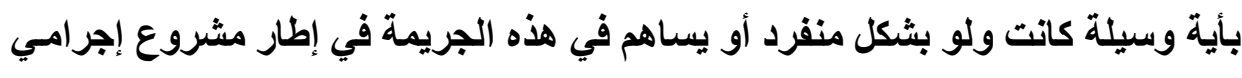


مشترك أو تولى قيادة أو زعامة أو إدارة أو إنشاء أو تأسيس أو اشترك في عضوية أي من الكيانات الإرهابية المنصوص عليها في المادة رقم ( (1) من قرار رئيس جمهوريـة مصر العربية بالقانون رقم 1 لسنه ه 1 ـ ب في شـأن تنظيم قوائم الكيانـات الإرهابية والإرهابيين أو يقوم بتمويلها أو يساهم في نشاطها مع علمه بذلك"

هذا التعدد في القوانين وتفريق التعريفـات والتغيير من عناصرها من شـأنه أن يثير بعض اللبس أحيانا، ومع ذلك فإنتـا نرى أن قانون مكافحة الإرهـاب يفضل قانقانون الكيانات الإرهابية في تعريفه للكيان أو الجماعة الإرهابية من حيث التالي: - أنه استخلم تعبير الإرهاب دون أن يقع في عيب تحديد مفهومه، تاركاً إياه للقواعد العامة وخاصة منها ما هو مشار إليه في المادة (؟^م) مكرراً عقوبات التي أشارت إلى قصد الترويع. هذا القصد هو في الحقيقة لب العمل الإرهابي والأي يميزه عن غيره من الأعمال العنيفة كمن يقوم بقتل أكثر من شخص دون توافر قصد الترويع كما في حالة الانتقام أو المشاجرات بين العائلات أو للاحتجـاج على مواقف معينة من السلطات. - يتفـق قـانون مكافحـة الإرهـاب وقـانون الكيانـات الإرهابيـة فـي تعريفـه للتنظيم الإرهابي عندما لم يساو بين التظيم القانوني والتظيم الفعلي. فلا يهم إذن أن يكون التظيم مشهرا وفقا للأوضاع القانونية أو يكون مجرد تجمع من الأفراد. - أحسن قانون مكافحـة الإرهـاب عمـلا عندما حدد عدد أفراد التنظيم بـأنهم ثلاثنة أشخاص فأكثر، وهو الأمر الأي لم يحرص قانون الكيانـات الإجرامية على ذكره. ونحن نتفق مع ذلك الرأي حيث إن الجماعة لا تكون والتنظيم لا يقوم من شخصين 
- يحمد لقـانون مكافحـة الإرهـاب عندما عرف الجماعـة الإرهابيـة بحرصـه على

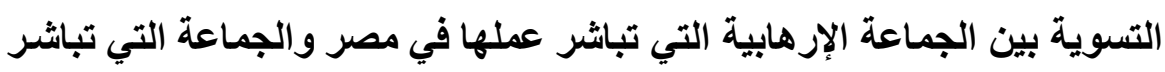

$$
\text { عملها في خارج مصر. }
$$

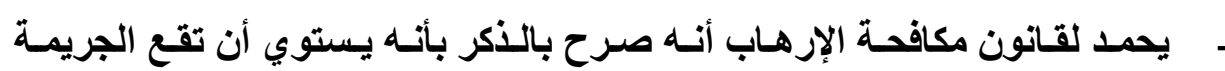

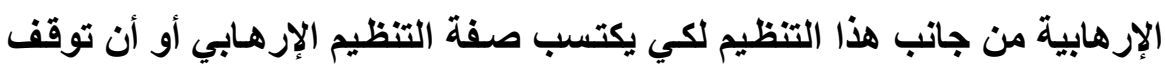

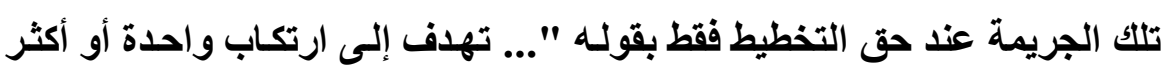

$$
\text { من جرائم الإرهاب"(المادة الأولى). }
$$

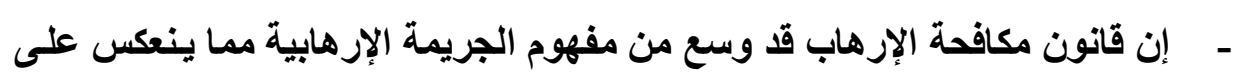

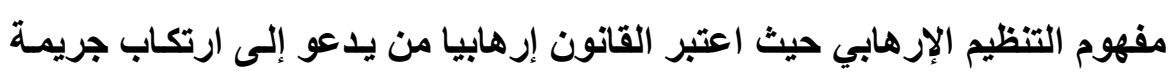

$$
\text { إرهابية وليس فقط من ارتكب جريمة إرهابية. }
$$

- -

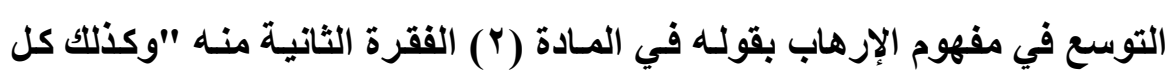

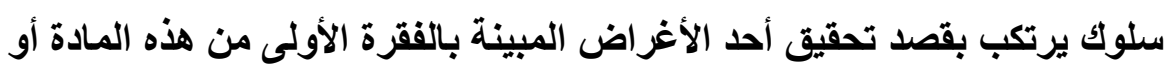

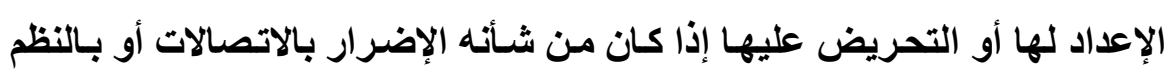

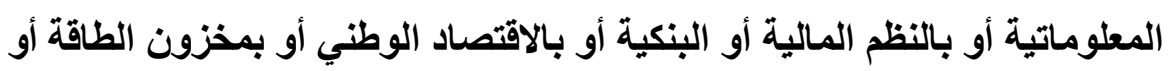

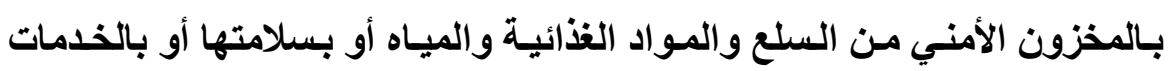

$$
\text { الطبية في الكوارث والأزمات" }
$$

ومع ذلك فإن قانون مكافحة الإرهاب يرد عليه الملاحظات التالية:

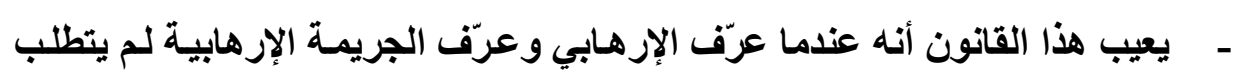

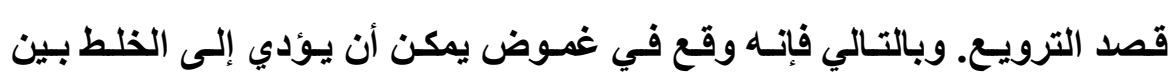
الأعمال العنيفة الإرهابية وغير ها من الأعمال العنيفة الأخرى. 
- يعيب قـانون مكافحة الإرهـاب في تعريفاتـه الزائدة والمتكررة، فجـاعت صياغته معيبة. فعرّف الإرهابي وعرف الجريمـة الإرهابية وعرف العمل الإرهابي، وكلها كان يمكن التعبير عنها في مادة وحيدة. - لم يتين قانون مكافحة الإرهاب بشكل صريح مبدأ العالمية بمعنى أنه لم يمد تطبيق القـانون المصري بحيث يسري على التظظيمـات الإرهابية التي تعتدي أو تخطط للاعتداء على أية دولة دون تقييد الأمر بالمصالح المصرية فتط.

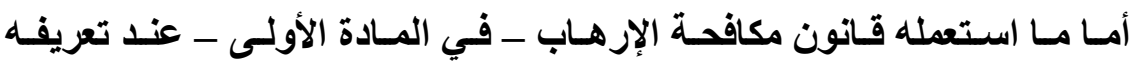
للإزهـابي من تعبير "يرتكب أو يشرع في ارتكـاب أو يحرض أو يهدد أو يخطط في الاخلل أو الخارج لجريمة إرهابية بأية وسيلة كانت" فإنه لا يقطع بتبني مبدأ العالمية، إذ الأصل هو مبدأ الإقليمية أي أن المقصود بالجريمـة الإرهابية هنـا هو مـا قع اعتداء على المصالح المصرية دون غيرها من مصالح الدول الأخرى. والجدير بالأكر أن بعض من تلك الجرائم الإرهابية يسري عليها وصف جرائم أمن الدولة التي يسري عليها مبدأ العينية حيث يسري القانون المصري على مرتكبي الفعل أياً كانت جنسيته وأياً كان مكان وقوع الجريمة.

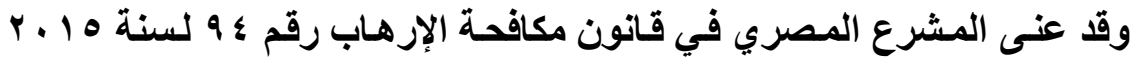
بـالنص على أكثر مـن معيـار في تحديـ سـريان قانون الإرهـاب واختصاص القضاء المصري بمحاكمة المتهم بهذا النوع من الجرائم عند توافر: (أ) مبدأ جنسية الطائرة ومبدأ العلم أو مسجلة في مصر أو تحمل علمها. (ب) مبدأ الشخصية الإيجابية أي عندما يكون المتهم مصريا (ج) مبأ الشخصية السلبية، إذا كان المجني عليه مصريا 
(د) مبدأ العينية عندما نصت عليه المادة الرابعة من قانون مكافحة الإرهـاب من تطبيق هذا القانون إذا كان الفعل الإرهابي يستهذف مصالح مصرية تثمثل في : أـ إلحاق الضرر بأي من مواطني مصر أو المقيمين فيها أو بأمنها أو بـأي من مصالحها أو ممتلكاتها في الاخل أو في الخارج أو بمقار ومكاتب بعثاتها الابلوماسية أو القصلية أو مؤسساتها أو فروع مؤسساتها في الخارج.

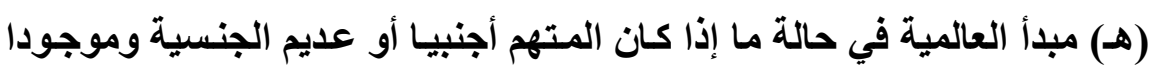
في مصر، والفرض هنا أن الجريمة الإرهابية وقعت في خارج البلاد، وإلا كان

$$
\text { مبدأ الإقليمية واجب التطبيق. }
$$

ومن حالات تطبيق مبدأ العالمية تطبيق قـانون مكافحة الإرهـاب إذا كـان الفعل الإرهابي يستهفف "إلحاق الضرر بأي من المنظمات أو الهيئات الدولية أو الإقليمية" وهنا لا يشترط أن تكون الهيئة مصرية، كما لا يشترط أن تكون تلك الأفعال واقعة على

$$
\text { الهيئات العاملة في مصر('). }
$$

كـان من الصحيح أن يفصل المشرع عن نيتهـه في تطبيق مبدأ العالميـة بنص صريح ولا يكتفي بالقول بأن التظظيم يعد إرهابيا أياً كان مكان وجود نشاطه ــ داخل أو

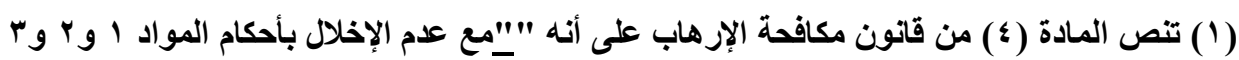

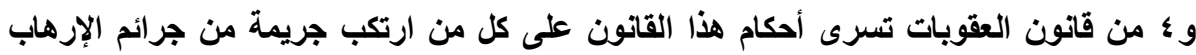

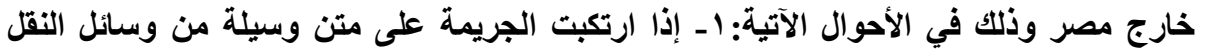

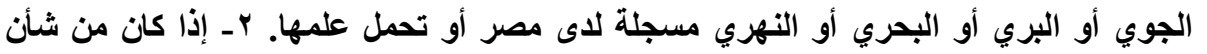

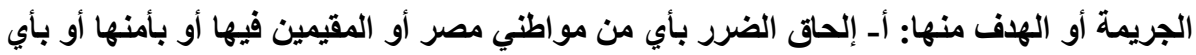

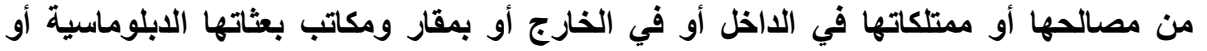

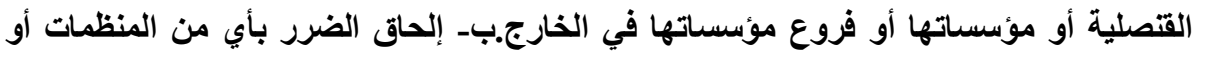

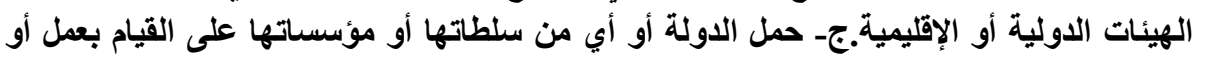

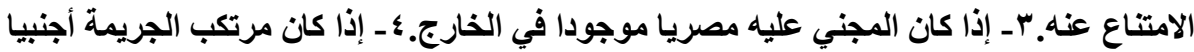

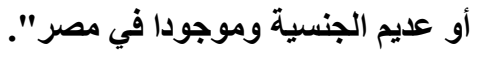


خارج مصر- وأياً كاتت جنسيته أو جنسية من ينتسب إليه. ويرجع السبب في ذلك إلى أن الجرائم المرتبطة بالتنظيم الإرهابي تقع ولو لم يقع فعل إرهابي أوكـان هنـاك مجني عليه من فعل معين، ولذا فإن صياغة قانون مكافحة الإرهـاب لا تسعف بـالنظر إلـى أنـا يسري على أفعال إرهابية وقعت بالفعل. ومـن الجدير أن تطبيت مبدأ العالمية يشكل إتجاها عالميا في جرائم التنظيمات الإرهابية حتى تلك التي لم تقع ويستحسن أن تتبنى مصر فكرته، تحقيقا لأكبر قدر ممكن من التعاون الدولي في مكافحة الإرهاب.

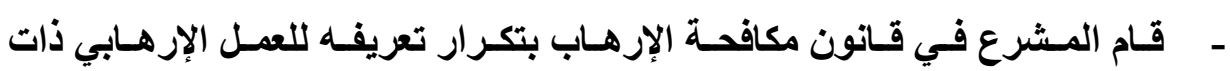
المفهوم الذي سبق أن أورده قانون الكيانات الإرهابية، فلم يكن هنـاك جدوى لهذا

$$
\text { التكرار خاصة وأنه لم يجدد في مفهومه شيئًا. }
$$

الخصائص الميهيزة للتنظيم الإرهابي:

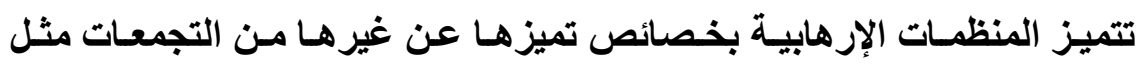

$$
\text { التنظيمات الإجرامية، من أهمها: }
$$

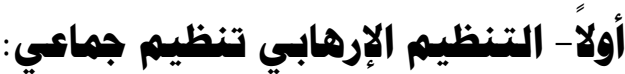

التظظيم الإرهـابي يقتضي بالـضرورة عدداً مسن الأشـخاص ومقداراً معينـا مـن

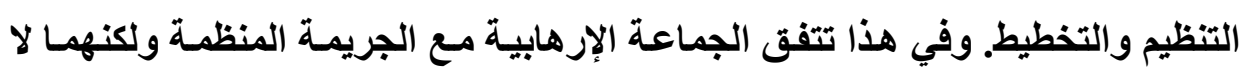
يزالان مختلفين في أهداف كل منهمـا. فبينمـا ينطلق التظيم الإرهابي من أيدولوجية معينة، فإن التظيم الإجرامي يسعى إلى تحقيق الربح. ولكن العلاقة بين النوعين من فن التهن التنظيم ليست غائبة('). ففي بعض الحالات يستعين التظيم الإرهابي بالتنظيم الإجرامي 
في نقل متفجرات أو أسـلحة يخطط التظظيم الإرهـابي لاستخدامها في ارتكـاب أعمـال إرهابية(').

وليس في القانون ما يستلزم ضرورة توافر عدد معين في التظيم الإرهابي حتى يكتسب تلك الصفة؛ فيمكن أن يتوافر باتفاق شخصين فقط. بهذا قضت محكمة النقض فئرئ الفرنسية(†) كما لا يشترط فيمن ينضم إلى منظمة إرهابية أن يعرف على وجه التحديد

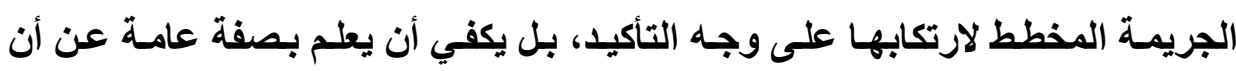

$$
\text { التنظيم بصدد ارتكاب أفعال إرهابية(") }
$$

وعلى الـرغم مـن أن نـص المـادة (421-2-1) عقوبـات فرنسـي يعاقب على

الانضمام إلى تنظيم إرهابي بغرض الإعداد لارتكاب عمل إرهابي، فإن القضاء الفرنسي يكتفي بانضمام المتهم إلى منظمـة إرهابية دون إثبات أن تلكك المنظمة تقوم بالإعداد لعمل إرهابي مـادام أنها إرهابية، لأنها لن تكون إرهابية إلآ لأنها ماضية في الإعداد

$$
\text { لارتكاب أفعال إرهابية( ). }
$$

ومن هنا فإن الخصوصية في مكافحة الجرائم الإرهابيـة تنعكس أيضا في شكل

الاكتفاء بالقيام بأعمال تجهيزية لارتكاب الجرائم من جانب التنظيم الإرهابي لكي يعتبر

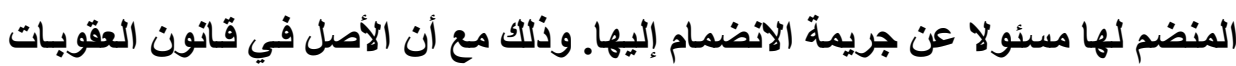

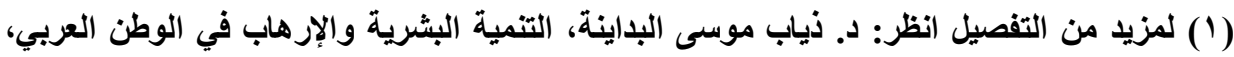

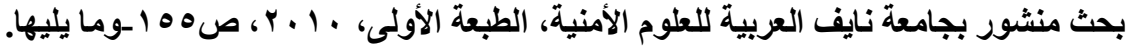

(2) Crim. 30 avr. 1996, Bull. crim. $n^{\circ} 176$; Crim. 3 juin 2004, $n^{\circ}$ 03-83.334.

(3) Paris, 10e Ch., section B, 25 avr. 1997, $\mathrm{n}^{\circ}$ 96/07152; Paris, 10e Ch. Section A, 26 janv. 1999, 98/01582 ; Paris, 10e Ch., section A, 26 juin 2000, 00/00190 ; Paris, 10e Ch. Section A, 19 nov. 2007, 07/01558.

(4) Crim. 21 mai $2014 n^{\circ}$ 13-83.758: Pierre de Combles de Nayves, Sauf en matière, AJ Pénal 2014 p. 528

مجلت البحوث القانونيتّ والإقتصاديت ب اب 


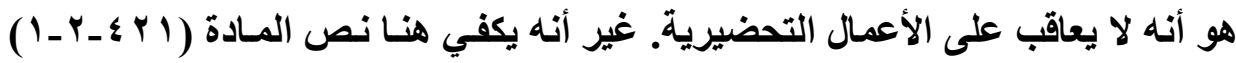
الذي جاء صريحاً في أنه مـادام انضمامه كـان لتنظيم يعد لارتكاب جرائم إرهابية، فإن جريمة الانضمام إلى تنظيم إرهابي تتوافر.

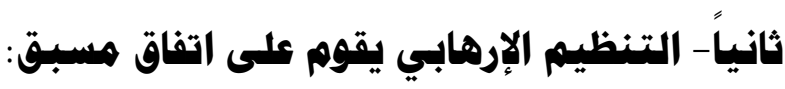

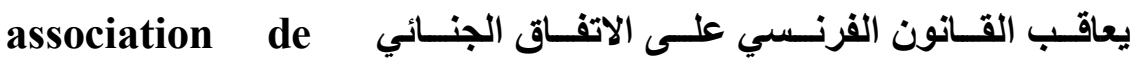
malfaiteurs توافر أربعة عناصر لتكامل أركـان تلكك الجريمـة: الأول وهو وجود اتفاق، الثاني وهو محل الاتفاق وهو ارتكاب جرائم، الثالث وهو القصد الجنائي المتمثل في العلم والإرادة،

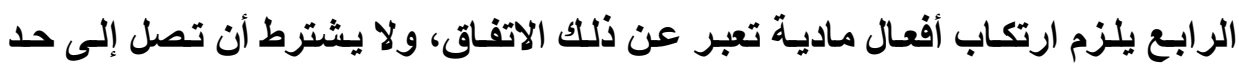
الثروع (البدء في التفيذ)( (). ولا يشترط في الاتفاق الجنائي أن يكون محله جرائم ذوات صبغة سياسية، بل يتوفر بالاتفاق على ممارسة العنف. وقد ثضي بذلك في قضية

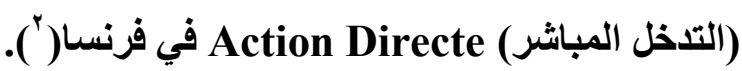
وتعاقـب بعـض التشريعات علـى الاتفــاق الجنــائي بغـرض ارتكــاب جـرائم إرهابية(r). من تلك التشريعات القانون الإيطالي في المـادة ( • rV ـ مكررا) من قانون العقوبـات التي تعاقب على الاتفـق على ارتكـاب جرائم الإرهـاب، سواء أكانت إرهابـا

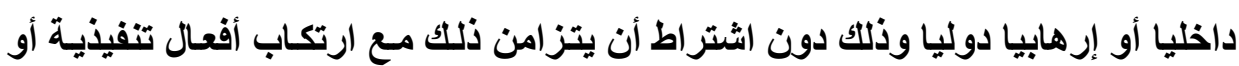
حتى تحضيرية. وقد قضت محكمة النقض الإيطالية بأنه لا يصح الاحتجاج بأن مـا صدر

(1) Cour d'appel de Paris en date du 4 juillet 1988 (n 2507/88, $^{\circ} 15$

(2) Cour d'appel de Paris en date du 4 juillet 1988, op.cit

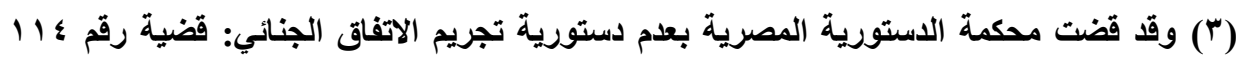
لسنة اب قضائية المحكمة الدستورية العليا "دستورية.

مجلتّ البحوث القانونيت والإقتصاديت ع اب 
مـن المـتهم في هذه الحالـة هو مجرد أقوال غير مشفوعة بأفعـال، ذلك أن النص لا يستلزم ذلكو('). كما لا يصح الاحتجاج بأن ذلك يتصادم مـع حريـة التعبير، ذلك أن تلكك الحرية ليست مطلقة، وتتعارض مع التآمر على ارتكاب الجرائم. فلكي تقع تلكك الجريمة وفقا لحكم محكمة النقض الإيطاليـة يلزم توافر العناصر التالية: أولاً- توافر خطة للقيام بأعمـال إرهابية دون اشتراط تحديد تلك الأفعال بشكل مفصل، ثانياً وجود تنظيم إرهابي يرمي المتهم إلى الانضمام إليه لمـا يشترك معـه في

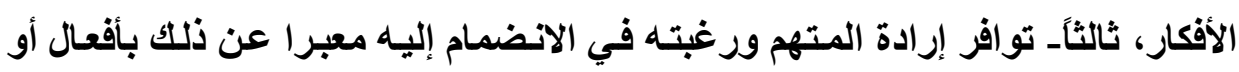
بأقوال دون اشتراك القيام بأعمال تتفيذية أو تحضيرية. وقد ثـارت مشكلة قانونيـة أمسام القضاء الإيطسلي بخصوص متهمسين مسلمين أرسلوا طردا ناسفا للعراق لاستخدامه ضد القوات الأمريكية هنـاك. فقد قضت محكمة أول درجة ببراءة المتهمين على سند من أنهم لـم يرتكبوا أعمالا إرهابية بـل صدرت مـنهم أعمـال عصابات gurilla ضــ القوات العسكرية. غير أن محكمـة الاسـتئناف نقضت الحكم واعتبرت أن تلك الأفعال تنتمي إلى الإرهاب الاولي. وعلى إثر ذلك أصدر المشرع الإيطالي قانونا في VV يوليو سنة ه . . . يعتبر أعمالا إرهابية كل عمل يرمي الهي

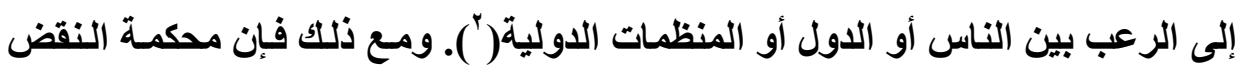
الإيطالية لا تتجه إلى وقوع الإرهاب الدولي في قضية اتهم فيها خمسة من المتهمين

(1) Court of Cassation, Section II Criminal (Corte di Cassazione, Sezione II Penale, Judgment No. 24994 of 25 May 2006, 71 J. Crim. L. 147 20062007: http://heinonline.org

(2) Michele Nino, Court of Cassation, Section II Criminal (Corte di Cassazione, Sezione II Penale) International Terrorism: Definition, Judgment No. 24994 of 25 May 2006, 71 J. Crim. L. 147 2006-2007: http://heinonleine.org 
الإسـلاميين إلا إذا اعتبرهم القانون الدولي الإنساني ضمن المقاتلين غير الشرعيين

$$
\text { كجرائم الحرب و الجرائم ضد الإنسانية('). }
$$

\section{ثالثاً - غرض التنظيم الإرهابي هو ارتكاب جريمة إرهابية:}

لا يكون التنظيم إرهابيا إلا إذا كـان غرضها ارتكاب جريمـة أو أكثر من الجرائم

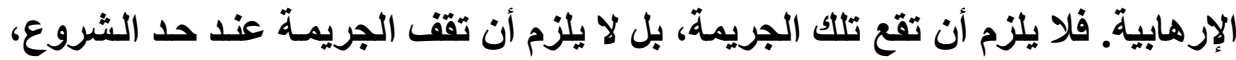
إذ يكفي أن تقع أفعال تحضيرية بقصد ارتكاب جريمة من تلك الجرائم. وتتمثل الجريمة الإرهابية في ارتكاب جرائم بقصد ترويع الناس. فإذا لم يظهر لاى أفراد التنظيم أن هدفه هو ترويع الناس، فِان التنظيم لا يعد

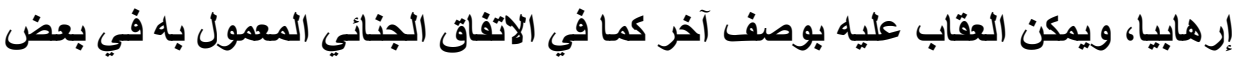
القوانين. مـع العلم بـأن المحكمة الدستورية في مصر قد قضت بعدم دستورية هذا

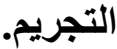
وتستدل المحكة على وجود قصد ارتكاب جرائم إرهابية من ظروف وملابسات الدعوى. من ذلك أن محكمة التمييز اللبنانية قضت بعدم توافر قصد الإرهاب من إقدام

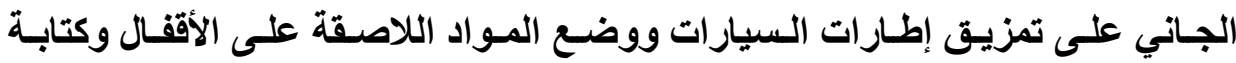
وتوزيع رسائل تهايد بهلف خلق البلبلة في إحدى المدن يثكل جرائم التخريب والتهايد العادي ولا ينطبق عليها وصف الأعمال الإرهابية المعاقب(").

(1)Decision 26 Juin 2006: 71 J. Crim. L. 147 2006-2007: http://heinonleine.org

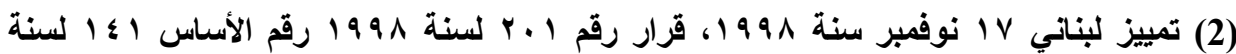
1919 19 ، أنظمة صلاح عبد الوهاب الجاسم.

مجلتّ البحوث القانونيت والإقتصاديت 


\section{رابعاً- التنظيم الإرهابي غرضه الدفاع عن قضية هعينة:}

يختلف التظيم الإرهابي عن التنظيم الإجرامي (الجريمـة المنظمة) في الغرض الذي تسعى من أجل تحقيقه('). فبينما يسعى التنظيم الإرهابي إلى الوصول إلى الحكم أو التأثير في السلطات لإرغامها على تحقيق مطالبة معينة، فإن التنظيم الإجرامي يسعى إلى تحقيق الربح المالي. ومن هنا كانت خطورة التظيم الإرهابي الذي يمكن أن

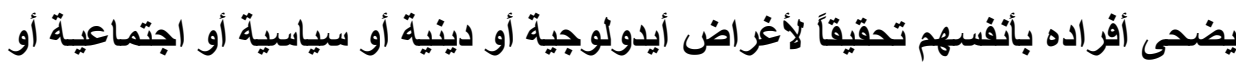

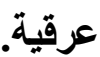

ويتفق الاثنان في وجود تدرج رئاسي بين أفراده. فعلى الرغم من أن القانون لم

يحدد خـصائص التنظيم الإجرامسي فإنـه يتميز بالتـدرج الرئاسـي، وتوزيـع المهام

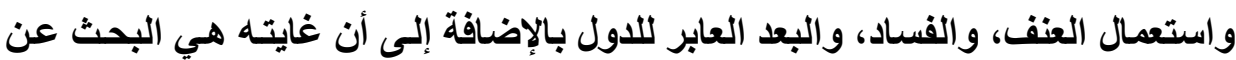

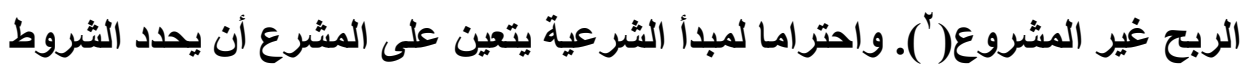
الواجب توافر في التنظيم لكي يقع تحت طائلة التجريم.

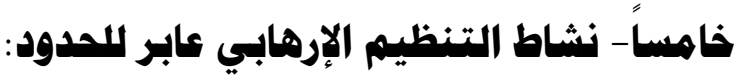
هنـاك من التنظيمـات الإجراميـة مـا يكون الغرض منـه ارتكـاب جرائم لتحقيق مكاسب مادية، وهنا تختلف تلكك المنظمات عن التنظيمات الإرهابية التي تحركها بواعث الإن (1) لمزيد من التفصيل انظر: د. عبالتواب معوض الثوريجي، تعريف الجريمة الإرهابية، دار

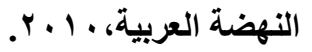

(2) Carole Girault, Le droit pénal à l'épreuve de l'organisation criminelle, RSC 1998 p. 715. 
أيدولوجية(') (). ولكن تتفق معها في وجود هيئة تنظيمية تقوم على وجود قيادة للتنظيم وأعضاء فيه وقواعد حاكمـه لـه. كمـا أن الجرائم المنظمـة قد تكون عـابرة للحدود وقد ينحصر نشاطها في حدود بلد واحد. وهي في ذلك مثل التنظيمـات الإرهابية التي قد تقتصر على دولة واحدة وقد يكون لها بعد دولي يمسارس مـا يسمى بالإرهـاب الدولي. وهذه الصورة هـي الأكثر حدوثا بسبب وجـود البواعث الأيدولوجيـة وبسبب وجـود مسساندة مـن خــارج الدولـة مسن تنظيمسات مماثـــة أو حتـى مـن دول أخـرى لهــا تلك الأيدلوجيات أو المصالح التي تجعلها تقوم بتشجيع وتمويل المنظمات المحلية. هذا النوعـان من التنظيــات يتوافر أحيانـا بينهمـا روابط من المصالح تجمـع بينهـا؛ فمـن ناحيـة تستعين التظيمـات الإرهابيـة بالتظيمـات الإجراميـة للحصول على الأسـلحة، وتقوم التنظيمـات الإرهابيـة بتزويـــ التنظيمـات الإجراميـة بالمخدرات وذلكك للحصول على المـال الـلازم للقيـام بأعمـال إرهابيـة. وقـد تستعين المنظمـات الإرهابيـة بالقـائمين

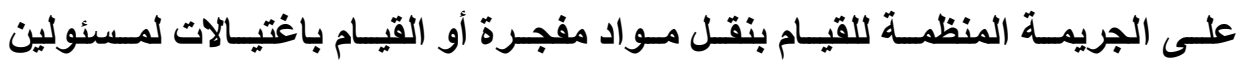
مناوئين لها.

(1) ODED LOWENHEIM, Transnational criminal organizations and security The case against inflating the threat, 57 Int'l J(INTERNATIONAL JOURNAL). 513 2001-2002, p.513: http://heinonline.org 


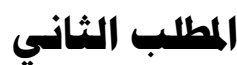

\section{التوسع في هفهوم المنظمة الإرهابية بسبب التوسع في هفهوم الجريمة الإرهابية}

اتجهت كثير مـن التشريعات المقارنــة إلـى التوسـع فـي مفهوم التتظيمـات الإرهابية. من ذلك القانون الوطني في الولايات المتحدة الأمريكية و القانون البريطاني

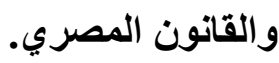

\section{توسع القانون الأهريكي في هفهوم التنظيسهات الإرهابية:}

$$
\text { توسع القانون الوطني الأمريكي في مفهوم الإرهاب على الوجه التالي: }
$$

1- أصبح يتضمن هذا المفهوم كل نشاط يتضمن أفعالا تعرض حياة الأشخاص للخطر بالمخالفـة لقـوانين الولايـات المتحـدة الأمريكيـة الفيدراليـة وقـوانين

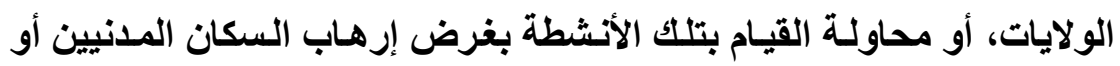

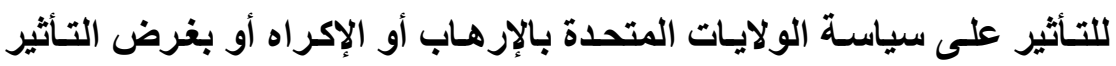

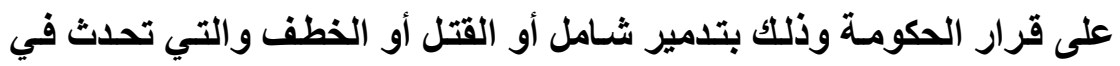

$$
\text { إقليم الولايات المتحدة (فصل r ب ـ من القانون الوطني). }
$$

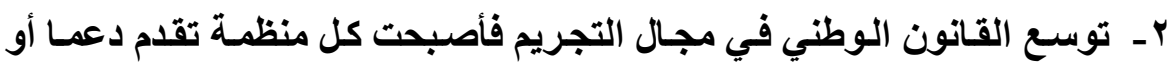

تمويلا لمنظمـة إرهابيـة تسري عليها أحكام المنظمـة إرهابيـة. ويستوي أن تكون المساعدة مادية أو غير مادية. فقد أصبحت المساعدة غير المادية لمن يرتكب جريمة إرهابية تثكل جريمة منفصلة (الفصل • (1). ويدخل في هذه الجريمة إيواء الإرهابي أو مساعدته بأي صورة مالية أو غير مادية. 
بمقتضى هذا التجريم أصبح تقديم مساعدة مالية أو حنى في شكل نصيحة يشكل جريمـة منفصلة مسادام أن المتهم يعلم أن تلكك المساعدة يمكن أن تستخدم في ارتكاب الجريمة الإرهابية. ولم يعد مشترطا توافر الركن المعنوي في المساهمة الجنائية ولكن يكفي أن يعلم المساعد أن مساعدته يمكن أن تستخدم في ارتكاب الجريمة الإرهابية. بـل لا يشترط أن تقع الجريمـة الإرهابيـة. كمـا أصبح نشر أهداف التنظيم نوعـا من الدعم

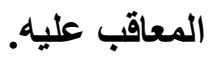

r- يعاقب القـانون الوطني على جريمـة التـآمر لارتكـاب جريمـة إرهابية (الفصل

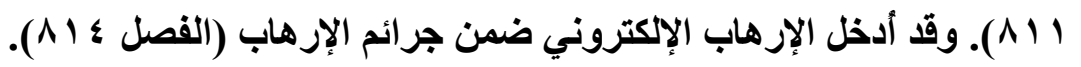

وقــ انعكس التوسـع الــي تبنـاه المسشرع الأمريكي علـى مفهوم المنظمـات الإرهابية، حيث إن التنظيم الإرهابي هو من يقوم أو يخطط أو يتآمر على ارتكـاب أفعال

the domestic وقــ عرّف القـانون الـوطني الأمريكي الإرهـاب الـداخلي

terrorism Y - بقصد تخويف أو إجبـار الأفراد المـنيين أو بقصد التأثير على سياسـة الحكومـة بـالتخويف أو الإجبـار أو بقصد التـأثير على سـلوك الحكومـة بالتـمير أو القتـل أو الخطف، بـ يحدث داخل إقليم الولايات المتحدة (الفصل r • ^)(').

(1) "the term 'domestic terrorism' means activities that--

(A) involve acts dangerous to human life that are a violation of the criminal laws of the United States or of any State;

(B) appear to be intended--

(i) to intimidate or coerce a civilian population; =

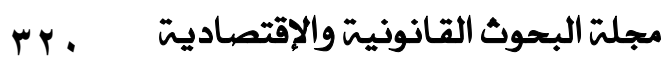




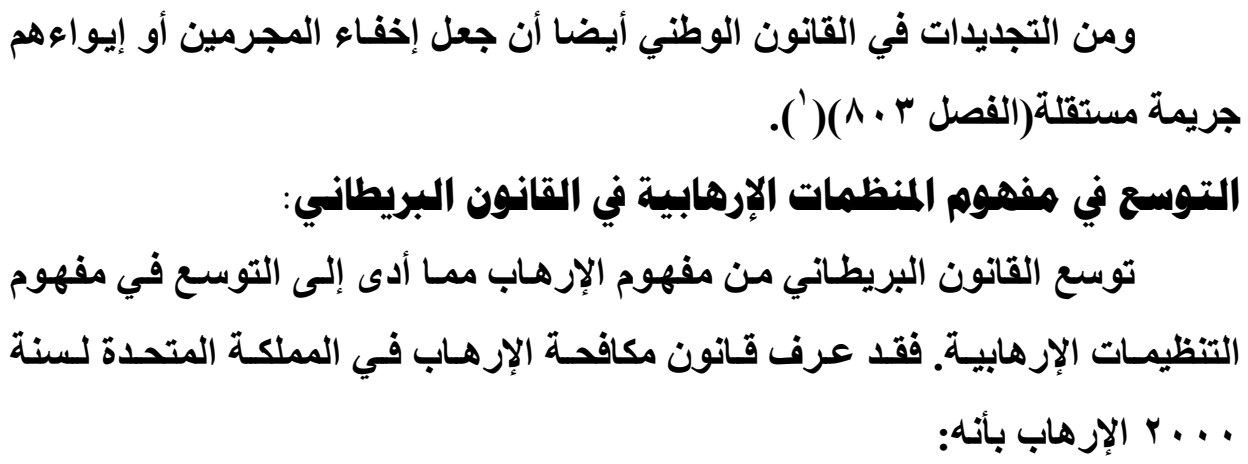

$=$ '(ii) to influence the policy of a government by intimidation or coercion; or'(iii) to affect the conduct of a government by mass destruction, assassination, or kidnapping; and

(C) occur primarily within the territorial jurisdiction of the United States.".

(1)"Whoever harbors or conceals any person who he knows, or has reasonable grounds to believe, has committed, or is about to commit, an offense under section 32 (relating to destruction of aircraft or aircraft facilities), section 175 (relating to biological weapons), section 229 (relating to chemical weapons), section 831 (relating to nuclear materials), paragraph (2) or (3) of section 844(f) (relating to arson and bombing of government property risking or causing injury or death), section 1366(a) (relating to the destruction of an energy facility), section 2280 (relating to violence against maritime navigation), section 2332a (relating to weapons of mass destruction), or section 2332b (relating to acts of terrorism transcending national boundaries) of this title, section 236(a) (relating to sabotage of nuclear facilities or fuel) of the Atomic Energy Act of 1954 (42 U.S.C. 2284(a)), or section 46502 (relating to aircraft piracy) of title 49, shall be fined under this title or imprisoned not more than ten years, or both.". 
(1) يقع تحت طائلة المبحث الثاني من هذا الفصل، إذا كان: (أ) يهدف الفعل أو التهايد به إلى التأثير على الحكومة أو هيئة حكومية دولية أو هي تخويف الجمهور أو جزء منه

(ب) أو أن القصد من الفعل أو التهديـ بـه هو تأييد قضية سياسية أو دينيـة أو عنصرية أو عقائدية (Y) يقع الفعل تحت طائلة هذا المبحث إذا كان: (أ) يتضمن عنفا جسيما ضد شخص (ب) يتضمن أضراراً جسيمة للأموال (ج) يعرض حياة شخص للخطر غير الثخص الذي يرتكب هذا الفعل (د) يعرض صحة الجمهور أو سلامته أو جزء منه لخطر جسيم (هـ) أعد لكي يسبب خلالا لنظام إلكتروني بشكل جسيم

(") يعتبر من أعمال الإرهاب استعمال أو التهديد باستعمال فعل يقع تحت طائلة الفقرة (Y) عندما يتضمن استعمالا لأسلحة نارية أو متفجرات سواء توافر فيه الشروط المنصوص عليها في الفقرة (1 - ب) أو لم تتوافر(').

(1)(1)In this Act "terrorism" means the use or threat of action where-

(a)the action falls within subsection (2),

(b)the use or threat is designed to influence the government [ [F1or an international governmental organisation] or to intimidate the public or a section of the public, and

(c)the use or threat is made for the purpose of advancing a political, religious [ $[\underline{2}$, racial] or ideological cause.

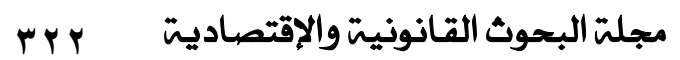


التوسع في تطبيق قانون العقوبات على التنظيسهات الإرهابية في الخارج:

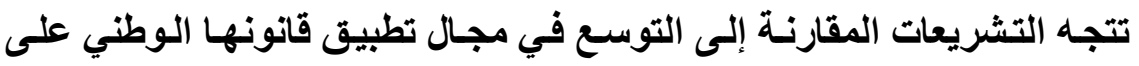

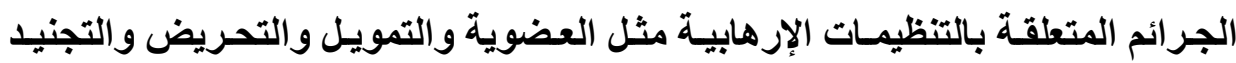

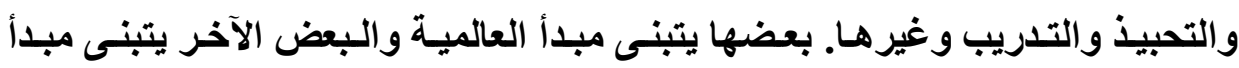
الثخصية السلبية والبعض الثالث مبدأ العينية.

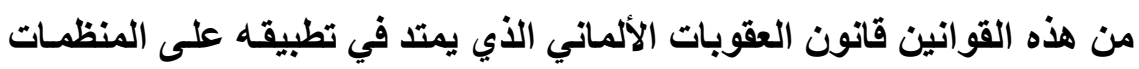

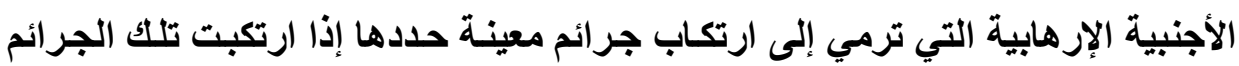

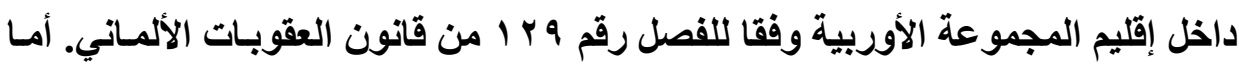
إذا كانت المنظمة الإرهابية تتواجد في خارج المجموعة الأوربية، فإن القانون الألماني

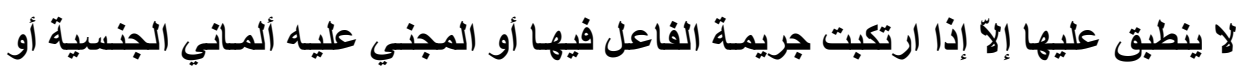

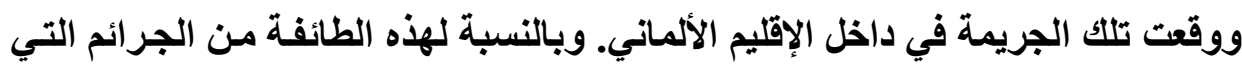
تقع في خارج الإقليم الألماني يلزم إذن وزير العدل لرفع الدعوى الجنائية(').

(2)Action falls within this subsection if it-

(a)involves serious violence against a person,

(b)involves serious damage to property,

(c)endangers a person's life, other than that of the person committing the action,

(d)creates a serious risk to the health or safety of the public or a section of the public, or (e)is designed seriously to interfere with or seriously to disrupt an electronic system.

(3)The use or threat of action falling within subsection (2) which involves the use of firearms or explosives is terrorism whether or not subsection (1)(b) is satisfied.

(3) http://www.gesetze-iminternet.de/englisch_stgb/englisch_stgb.html\#p1217 
أ.د/ شيماء عبد الغنى محمد عطا الله

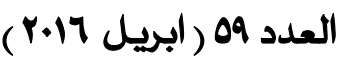

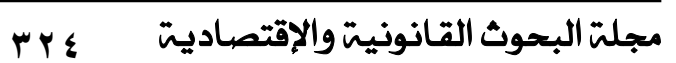




\section{المبحث الثاني \\ آلية تمديد المنظمات الإرهابية}

\section{البهة المسئولة عن تصديد المنظهات الإرهابية:}

تختلف التشريعات في تحديد الجهة المسئولة عن تحديد المنظمسات الإرهابية،

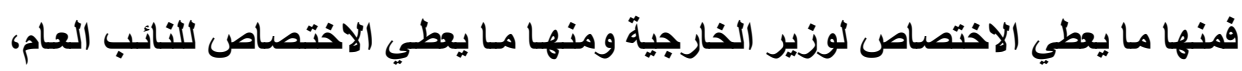
ومنها من اختار القضاء لكي يقوم بتلك المهمة بناء على طلب من النائب العام، ومنها

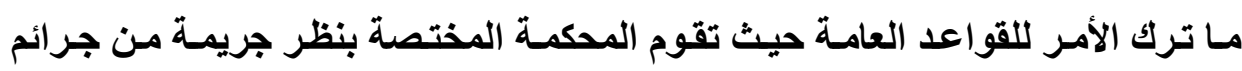

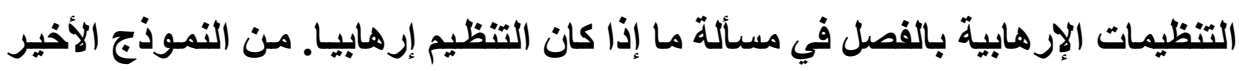

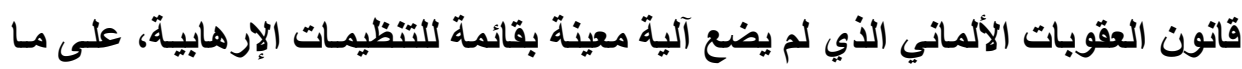

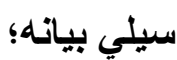

\section{آلية تحديد المنظمات الإرهابية في قوانين مكافحة الإرهاب في المملكة المتحدة:} أعد المشرع في الملكة المتحدة قائمة تضم التنظيمات الإرهابية، احتراما لمبدأ

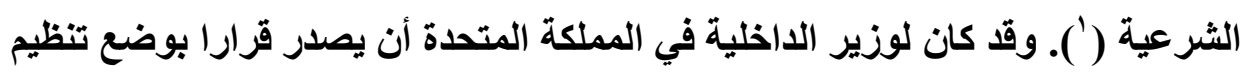

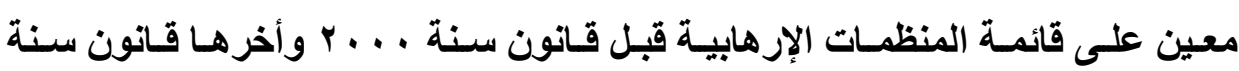

(1) Section 3. SCHEDULE 2

PROSCRIBED ORGANISATIONS The Irish Republican Army. Cumannnam Ban. Fiannanah Eireann. The Red Hand Commando. Saor Eire. The Ulster Freedom Fighters. The Ulster Volunteer Force. The Irish National Liberation Army. The Irish People's Liberation Organisation. The Ulster Defence Association. The Loyalist Volunteer Force. The Continuity Army Council. The Orange Volunteers. The Red Hand Defenders. 
919 19، ثم آلت تلك السلطة إلى وزير الخارجية وفقا لقانون سنة . . . ب لأن الأمر

يتعلق في غالبيتهـ بتنظيمـات أجنبيـة('). وبالفعل فـإن لائحسة المنظمـات الإرهابية في

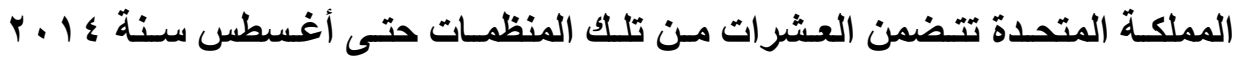

غالبيتها منظمات إسلامية متطرفة(ّ). ولم يمنع ذلك من وجود منظمات إرهابية داخلية

$$
\text { وخاصة بايرلندا الشمالية في قائمة المنظمات الإرهابيةة( ). }
$$

(1) http://www.legislation.gov.uk/ukpga/2000/11/contents

(2)17 November Revolutionary Organisation (17N)

- Abdullah Azzam Brigades (AAB) including the Ziyad al-Jarrah Battalions

- Abu NidalOrganisation (ANO)

- Abu Sayyaf (ASG)

- Al-Gama'at al-Islamiya (GI)

- Al Gurabaa

- Al Ittihad Al Islamia (AIAI)

- Al Murabitun

- Al Qa'ida

- Ansar Al Islam (AI)

- Ansar Al Sharia-Tunisia (AAS-T)

- Ansar Al Sunna (AS)

- Ansar Bayt al-Maqdis (ABM)

- AnsarulMuslimina Fi Biladis Sudan (Vanguard for the protection of Muslims in Black Africa) (Ansaru)[11]

- Armed Islamic Group (GroupeIslamiqueArmée) (GIA)

- Asbat Al-Ansar ('League of Parisans' or 'Band of Helpers')

- BabbarKhalsa (BK)

- Baluchistan Liberation Army (BLA)

- Basque Homeland and Liberty (Euskadi ta Askatasuna) (ETA)

- Boko Haram (Jama'atu Ahli Sunna LiddaAwatiWal Jihad) (BH)

- Egyptian Islamic Jihad (EIJ)

$=$

مجلتّ البحوث القانونيت والإقتصاديت ب ب ب 
- Groupe Islami que Combattant Marocain (GICM)

- HamasIzz ad-Din al-Qassam Brigades

- Harakat-Ul-Jihad-Ul-Islami (HUJI)

- Harkat-ul-Jihad al-Islami (HUJI-B):

- Harakat-Ul-Mujahideen/Alami (HuM/A) and Jundallah

- Harkat-ul-Mujahideen (HM)

- Hezb-e-IslamiGulbuddin (HIG)

- Hizballah External Security Organisation

- ImaratKavkaz (IK) (also known as the Caucasus Emirate)

- Indian Mujahideen (IM)[12]

- International Sikh Youth Federation (ISYF)

- Islamic Army of Aden (IAA)

- Islamic State of Iraq and the Levant (ISIL) also known as Dawlat al'Iraq al-Islamiyya, Islamic State of Iraq (ISI), Islamic State of Iraq and Syria (ISIS) and Dawlat al Islamiya fi Iraq wa al Sham (DAISh) and the Islamic State in Iraq and Sham

- Islamic Jihad Union (IJU)

- Islamic Movement of Uzbekistan (IMU)

- Jaish e Mohammed (JeM) and splinter group KhuddamUl-Islam (Kul)

- Jammat-ulMujahideen Bangladesh (JMB)

- Jeemah Islamiyah (JI)

- Kateeba al-Kawthar (KaK) also known as "Ajnad al-sham" and "Junudar-Rahman al Muhajireen"

- KhuddamUl-Islam (Kul) and splinter group JamaatUl-Furquan (JuF)

- Kurdistan Workers Party (PartiyaKarkeren Kurdistan or Kongra-Gel) (PKK)

- Lashkar e Tayyaba (LT)

- Liberation Tigers of Tamil Eelam (LTTE)

- MinbarAnsarDeen (also known as Ansar al-Sharia UK)

- Palestinian Islamic Jihad - Shaqaqi (PIJ)

$=$ 
- Popular Front for the Liberation of Palestine-General Command (PFLP-GC)

- Revolutionary Peoples' Liberation Party - Front (DevrimciHalkKurtulusPartisi - Cephesi) (DHKP-C)

- Salafist Group for Preaching and Combat (GroupeSalafiste pour la Predication et le Combat) (GSPC)

- Sipah-E Sahaba Pakistan (SSP) (renamed Millat-E Islami Pakistan (MIP) in April 2003) and splinter group Lashkar-e-Jhangvi (LeJ)

- Libyan Islamic Fighting Group (LIFG)

- Saved Sect or Saviour Sect

- TehrikNefaz-e Shari'atMuhammadi (TNSM)

- TeyreAzadiye Kurdistan (TAK)

- TurkiyeHalkKurtulusPartisi-Cephesi (THKP-C) also known as the Peoples' Liberation Party/Front of Turkey, THKP-C Acilciler and the Hasty Ones

- (1 ) Continuity Army Council (CAC)

- CumannnamBan

- FiannanahÉireann, a name claimed by multiple groups

- Irish National Liberation Army (INLA)

- Irish People's Liberation Organisation (IPLO)

- Irish Republican Army (IRA), a name claimed by multiple groups

- Loyalist Volunteer Force (LVF)

- Orange Volunteers

- Red Hand Commando

- Red Hand Defenders

- Saor Éire

- Ulster Defence Association (UDA)

- Ulster Freedom Fighters (UFF)

- Ulster Volunteer Force (UVF) 


\section{هعايير وضع المنظمة على قائمة الإرهاب في القانون البريطاني:}

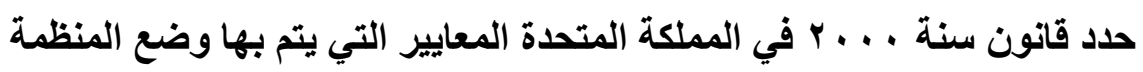

على قائمة الإرهاب، وذلك في الفصل الثالث (المبحث الأول) بقوله:

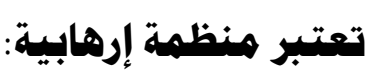

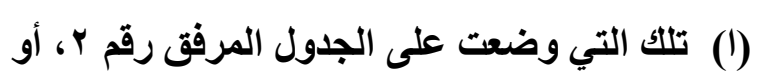

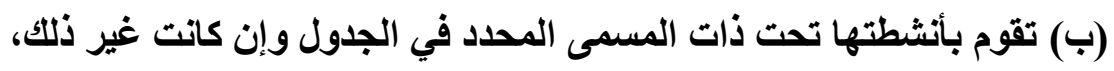

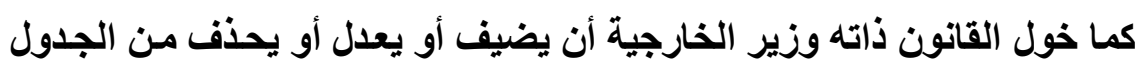

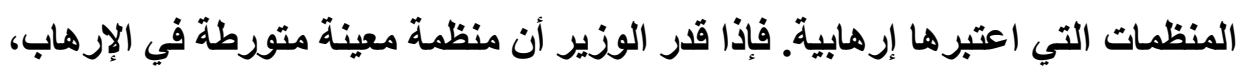

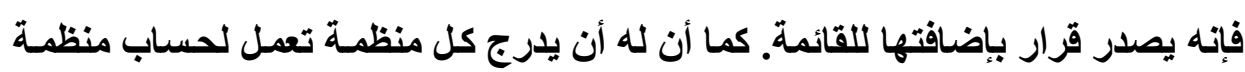

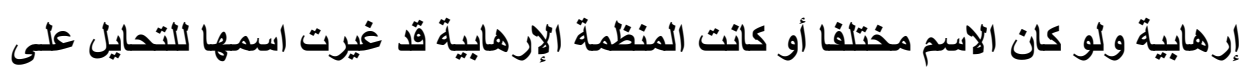

وضعها على قائمة الإرهاب عند توافر ذات شروط الاست المنظمة الإرهابية فيها.

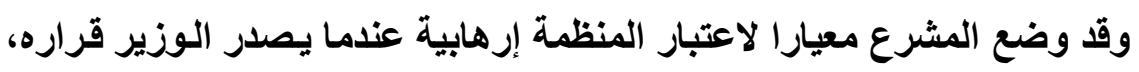

$$
\begin{aligned}
& \text { بقوله: تعتبر المنظمة إرهابية لو أنها : } \\
& \text { (1) ارتكبت أفعالا إرهابية أو ساهمت في ارتكابها، }
\end{aligned}
$$

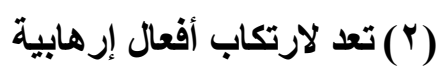

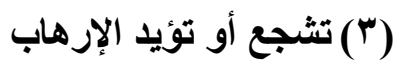

$$
\begin{aligned}
& \text { تكورط بأي شكل كان في الإرهاب الإرهاب }
\end{aligned}
$$

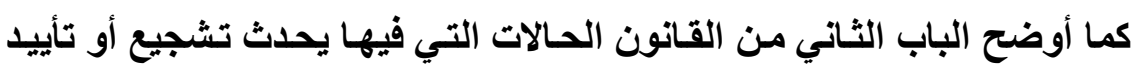

$$
\text { الإرهاب الذي يضفي على المنظمة طابعا إرهابيا، وهي: }
$$

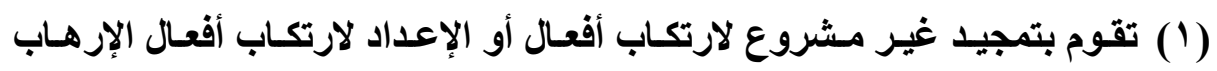

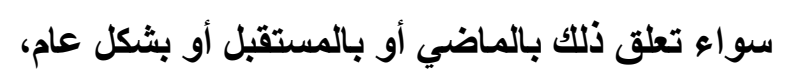

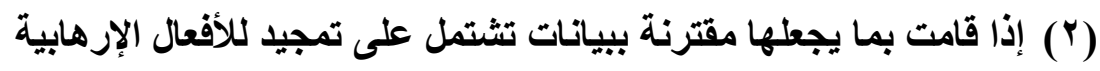




\section{آلية تهديد المنظمة الإرهابية في القانون الأهريكي:}

ينص الفصل ^ من التقنين الجنائي للولايات المتحدة الأمريكية (الفقرة 9 (1) ( )

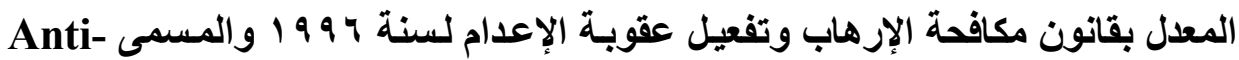
terrorism and Effective Death Penalty Act 1996 (AEDPA) يقوم وزير الخارجية بتعيين المنظمات الإرهابية الأجنبية. وقيام الوزير بتحديد المنظمات التي تعتبر إرهابية لا يخالف مبدأ شرعية الجرائم والعقوبات التي تقتضي أن يكون تحديد أركان الجريمة (وشروطها المسبقة) بقانون، مادام أن القانون فوض الوزير للقيام بذلك. ويتفق ذلك مع قوانين جنائية أخرى كما في قانون المخدرات الذي قضي بعدم مخالفته للاستور على الرغم من قيام وزير الصحة بإضـافة مواد تعتبر من المخدرات. وقد استتـد هذا القضاء إلى جـواز التفويض مـن

القانون لوزير الصحة في تحديد المواد المخدرة(').

(1) في هذا المعنى قضت المحكمة الدستورية بأنه " وحيث إن المسادة 77 من الاستور الحالي تنص

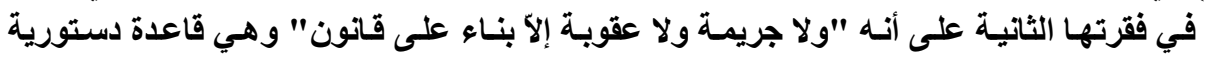

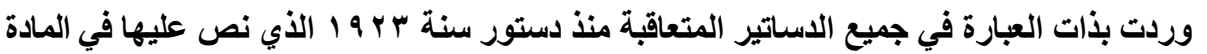

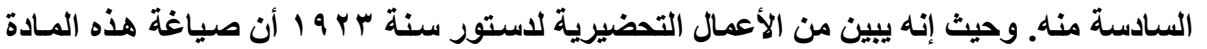

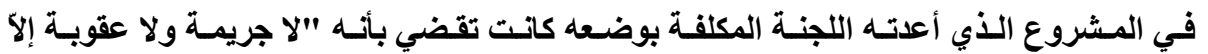

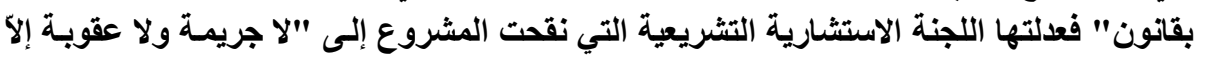

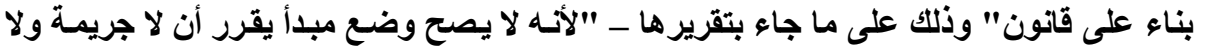

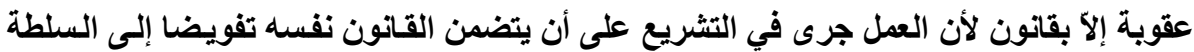

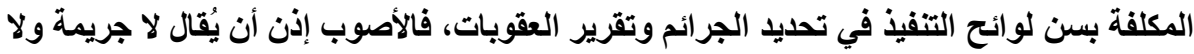

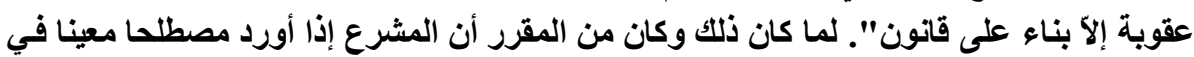

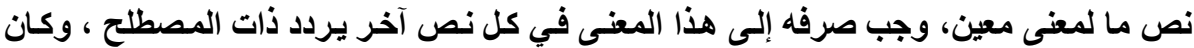

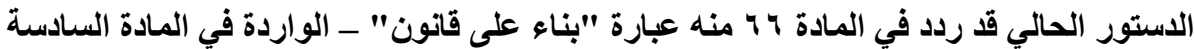

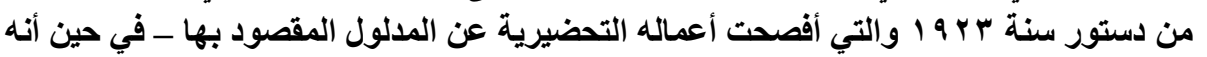

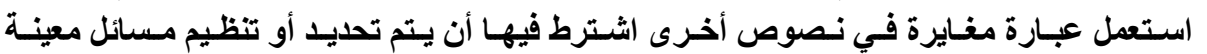

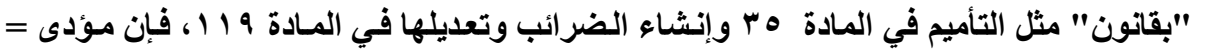


= ذلكك أن المـادة 7 = من الاستور تجيز أن يعهد القانون إلى السلطة التنفيذية بإصدار قرارات

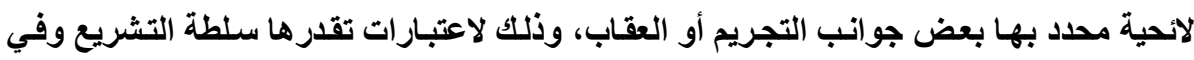

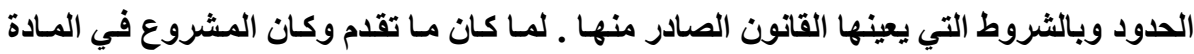

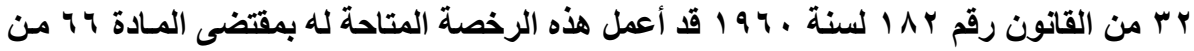

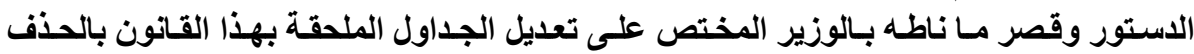

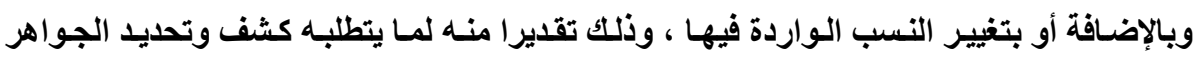

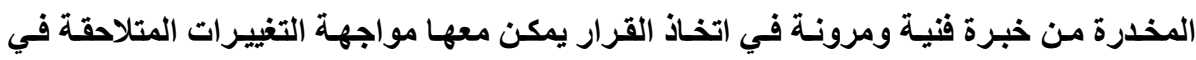

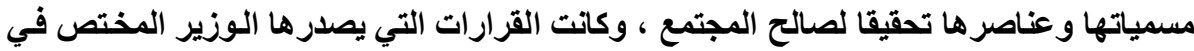

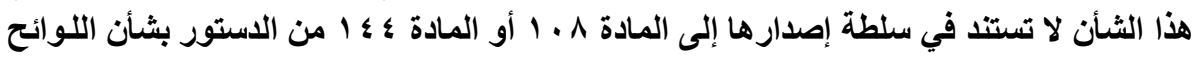

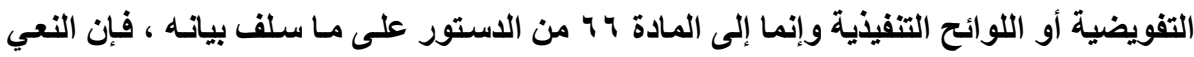

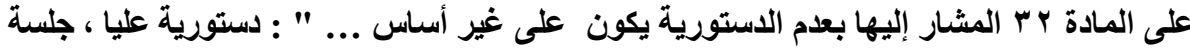

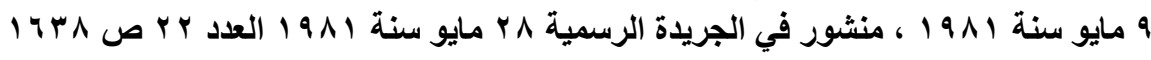

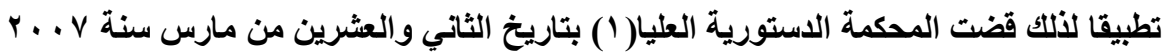

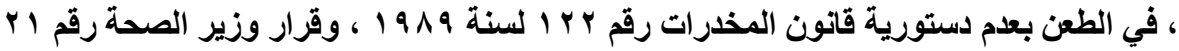

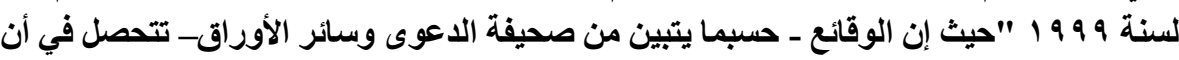

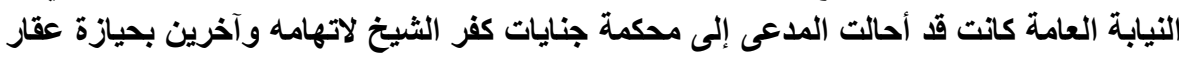

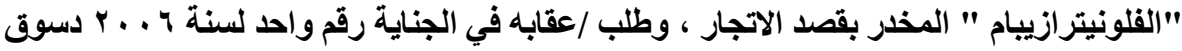

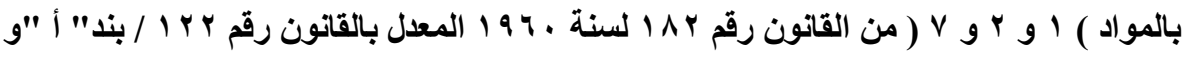

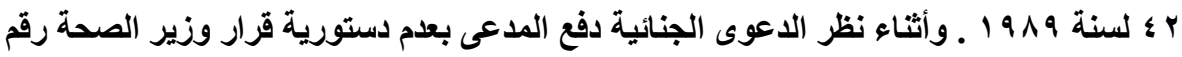

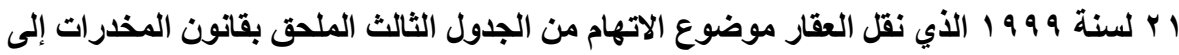

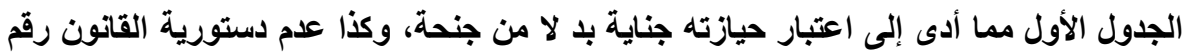

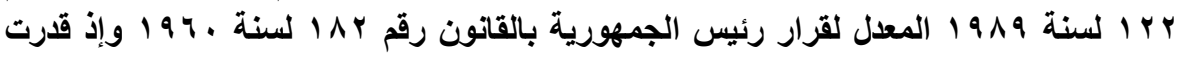

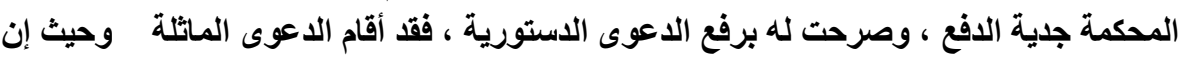

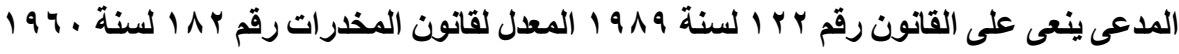

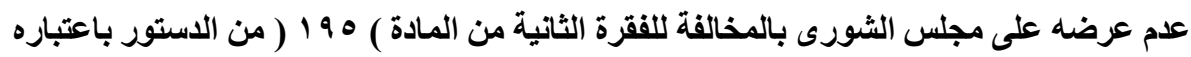

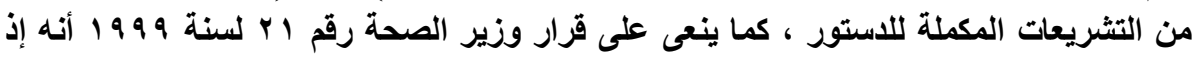

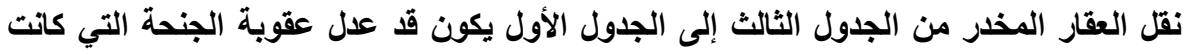

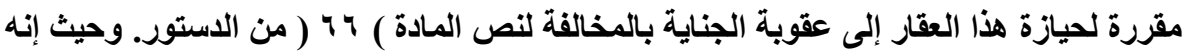

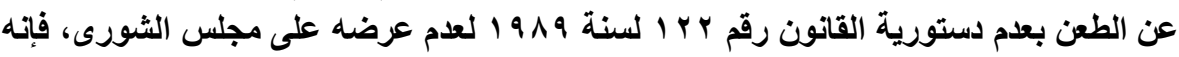

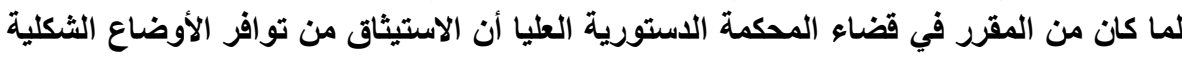

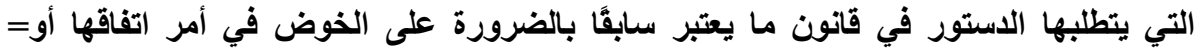


ولكي يصل إلى تللك النتيجة فإنه يقوم بتحديد أولا : - أن المنظمة أجنبية، ثانياأن المنظمة تتورط في أعمال إرهابية، ثالثاء أن المنظمة تهدد أمن الولايـات المتحدة أو أمن المواطنين الأمريكيين. كمـا يقوم الوزير بتحديد الأسماء المختلفة التي يمكن أن

تطلقها المنظمة على نفسها ولو كان الغرض منها التمويه لإخفاء هويتها الحقيقية. وقد عرف الفصل ^1 في فقرتـه 1182 المنظمـة الإرهابيـة بأنها التي : 1 توصف بأنها إرهابية وفقا لقانون البلا الذي تباثر فيه نشاطها أو توصف بأنها إرهابية وفقـا لمـا يأخذذ بـه القـانون الأمريكي، (Y) تلكك التـي تورطت في ارتكـاب أفعـال معينـة

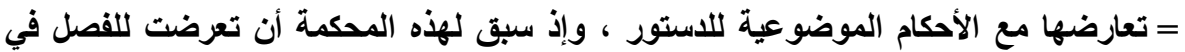

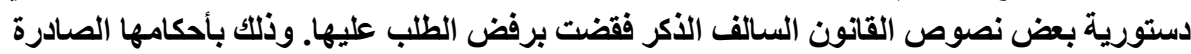

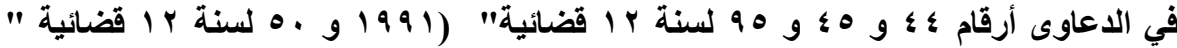

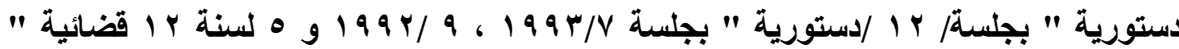
دستورية" ، الأمر الذي يضحى معه هذا القانون قد تطهر برمته من أية مخالفة شكلية لأحكام

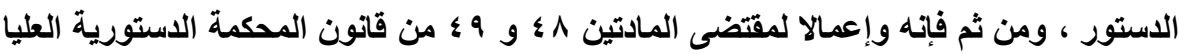

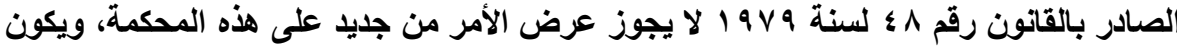

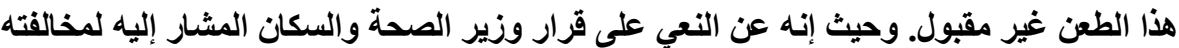

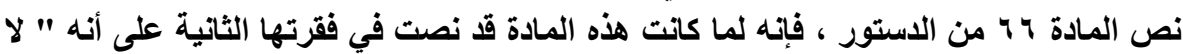

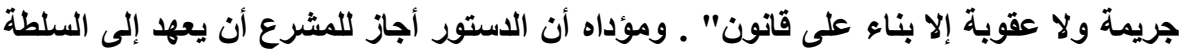

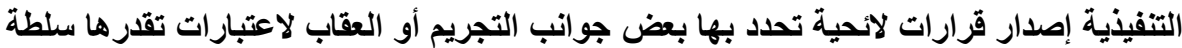

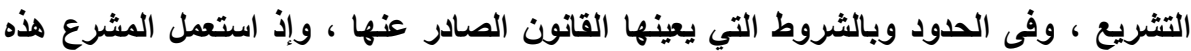

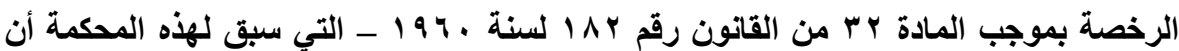

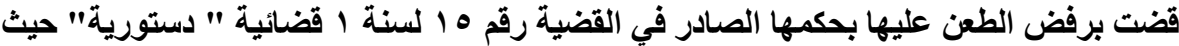

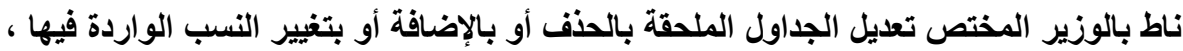

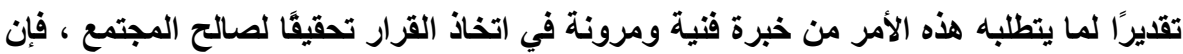

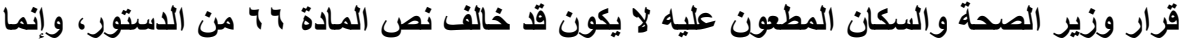
جاء تطبيقًا لها، بما يجعل النعي عليه بما تقدم غير سديد ومن ثم يتعين القضاء برفض الأل الدوى ". 


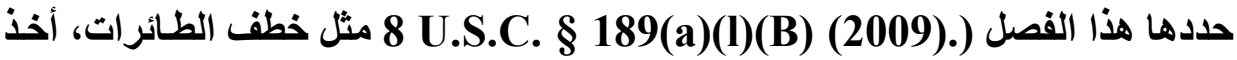
رهائن، القتل، استخدام أسلحة بيولوجية أو نووية. ولا يشترطوفقا لنص الفصل الثامن عشرة أن تقوم المنظمـة بأفعـال إرهابية بالفعل، بل يكفي أن تتوافر لايها القدرة والنية للقيام بتلك الأفعال. وتشتخلص تلكك النية من التخطيط والإعداد للقيام بتلك الأفعال وإن لم تصل إلى مرحلة البدء في التنفيذ. ويتم تجميع المعلومات التي تساعد الوزير في أداع مهامـه في تعيين المنظمـة الإرهابية مـن مصادر غير محددة. وتششمل تلكك المـصادر معلومـات تـم تجميعها مـن مصادر سرية ومن الصحافة ومن شبكة الانترنت. هذه المصادر تعتبر سرية لا يتم إفثاؤها إلى صـاحب الشأن أو غيره ماعدا بعض أعضاء الكونجرس الأمريكي وإلى المحساكم. وفـي هذه الحالـة الأخيـرة لا يـتم إفشـاؤها في جلسة علنيـة بـل في غرفـة المشورة in camera وفي غياب صاحب الثأن (')ex parte تهديد التنظيسمات الإرهابية في القانون الاسترالي:

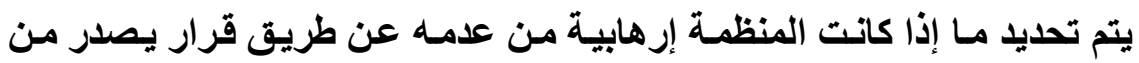
المحامي العام في استراليا، إما بمبادرة منه أو بناء على قرار بـلتك من الأمم المتحدة

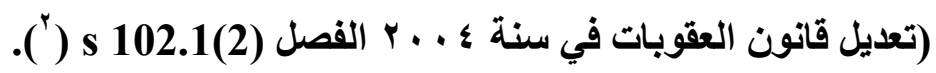

(1) People's Mojahedin Org. of Iran v. U.S. Dep't of State ("PMO"'), 182 F.3d 17, 18-19 (D.C. Cir. 1999).

(2) Andrew Lynch, Nicola McGarrityand George Williams*THE PROSCRIPTION OF TERRORIST ORGANISATIONS IN AUSTRALIA, 37 Fed. L. Rev. 1 2009, (Federal Law Review): www.heinonline.org. 


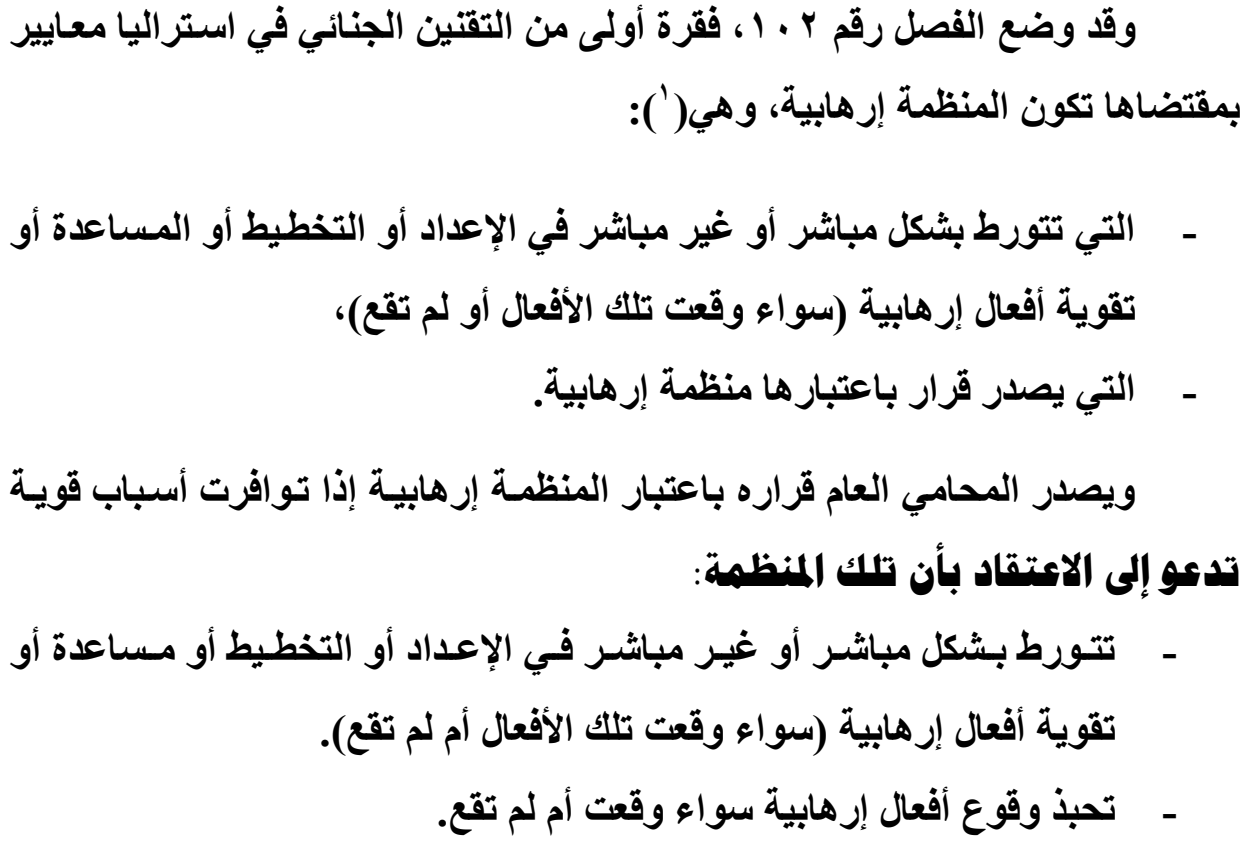

(1) "The government can list an organisation as a terrorist organisation if the Attorney-General is satisfied that it:

- is engaged in preparing, planning, assisting or fostering the doing of a terrorist act or

- advocates the doing of a terrorist act.

An organisation advocates the doing of a terrorist act if it directly or indirectly:

- counsels, promotes, encourages or urges the doing of a terrorist act

- gives instruction on the doing of a terrorist act

- directly praises the doing of a terrorist act, where there is a substantial risk that this praise might lead someone to engage in a terrorist act."

https://www.ag.gov.au/nationalsecurity/counterterrorismlaw/pages/te rroristorganisations.aspx 
ومن ناحية إدراج المنظمة على قائمة الإرهاب فإنه يبدأ إذا اقتنع المحامي العام

بأن منظمة معينة متورطة في الإرهاب، فإنـه يرفع الأمر إلى رئيس السلطة التنفيذيـة الذي يصدر القرار النهائي بذلك('). وقد تضمن القانون الاستر الي ضمانة مهمة هو أن القرار بحظر التنظيم لا يصدر إلآ بعد مقابلة زعيم المعارضة. وواضح أن العلة من ذلتك ألا يستخدم ذللك في حظر أحزاب المعارضة والأنشطة النقابية. كما أن قرار الحظر يجب أن يكون مسبوقا بالعرض على لجنة منبثقة من البرلمان في استراليا. كما أن وزير الخارجية الاسترالي عليه أن يصدر قرارا باعتبـار تنظيمـات معينة إرهابية إذا أصدر مجلس الأمن قرارا باعتبارهـا كذلك. كمـا أن مجلس الأمن بالإضـافة إلى اعتباره تنظيمات معينة بالاسم تنظيمات إرهابية قد وضع قاعدة عامـة بوجوب أن تقوم كل دولـة بإدراج منظمـة معينـة أو أشخاص معينين على قائمـة الإرهـاب وبالتـالي تجميد أمـوالهم "إذا ارتكبـت أو حاولت أن ترتكب أعمـالا إرهابيـة أو تسـاهم في تلكت الأعمـال أو تسهل القيـام بها، كمـا يتم تجميد أموال الشركات والجهات التي يمتلكهـا هؤلاء الأشخاص أو تلك التظظيمات أو يسيطرون عليها بشكل مباثر أو غير مباشر، وكذلك تجميا أموال كل شخص أو جهة تعمل لحساب هذا الشخص أو ذلك التظظيم أو تحت إدارته. ويشمل الحظر الأموال المتحصلة من استعمال أموال هؤلاء الأشخاص أو تلك المنظمـات وكذلك الأمـوال المتحصلة مـن تلك الأمـوال التـي يسيطرون عليهـا". ('UNSC') Resolution 1373)

(1)JOO-CHEONG THAM, POSSIBLE CONSTITUTIONAL OBJECTIONS TO THE POWERS TO BAN 'TERRORIST' ORGANISATIONS, 27 U.N.S.W.L.J. (UNSW Law Journal) 482 2004: http://heinonline.org 
ويترتب على صدور قرار الحظر مسئولية جنائية لمن يقوم بتدريب أعضاء في

هذا التنظيم أو يتلقى تـريبا منهم. وتقع الجريمـة إذا كـان المتهم عالمـا بـان التنظيم محظور بسبب الإرهاب. غير أن القانون الاستر الي لم يستلزم العلم بل اكتفي بـأن يقدم المتهم على هذا الفعل بلدون اهتمسام أو اكتراث، الأمر الذي يشكل توسـعا من المشرع الاستر الي ويجعل الجريمة تقع بالعمد أو بالإهمال في التحقق مـن أن المنظمـة محظورة

لتورطها في أعمال إرهابية (Criminal Code s 102.5) وضع قائمسة بالتنظيسمات الإرهابية في دولة الإمارات: تقوم جهات تنفيذيـة في بعض البلاد العربيـة بتحديد قائمسة تضم التظيمـات الإرهابيـة دون أن تترك تلك المهمـة إلى القضاء. من ذلك أن دولـة الإمسارات العربيـة المتحدة تعطي الاختصاص لمجلس الـوزراء للقيـام بتلك المهــة. وقد أصدر مجلس الـوزراء في دولـة الإمـارات قرارا بقائمسة تضم هـ منظمـة اعتبرهـا مجلس الوزراء

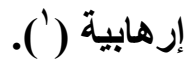

(1) جماعة الإخوان المسلمين الإماراتية .ـ دعوة الإصلاح (جمعية الإصلاح) .- حركة فتح الإسلام

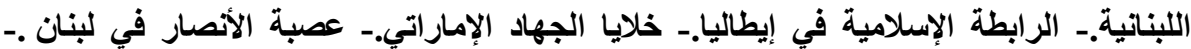

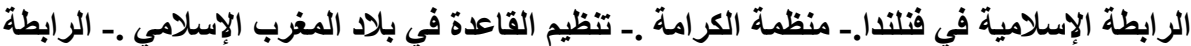

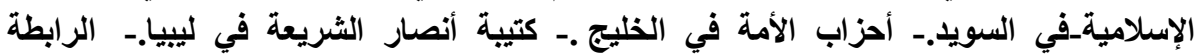

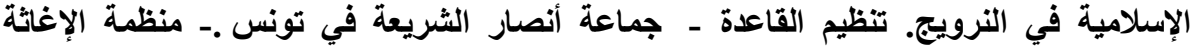

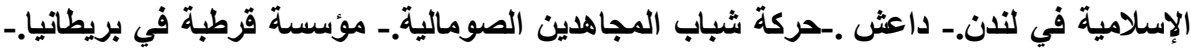

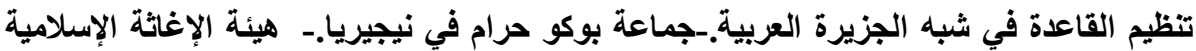

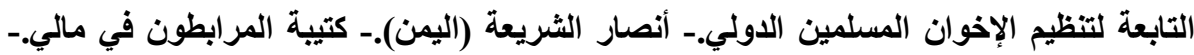

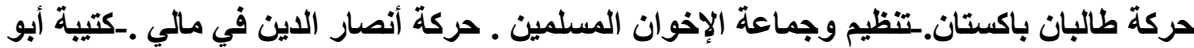

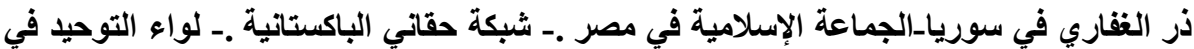

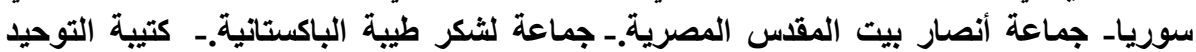

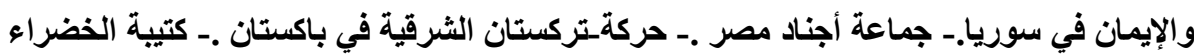
في سوريا.ـمجلس شورى المجاهلين .- أكناف بيت المقس .- جيش محمد في باكستان. 


\section{الاعتزاض الخاص بحرية التعبير في قضاء المكمة الأوربية لحقوق الإنسان:}

أثثيرت مشكلة تعارض القواعد التي تحدد المنظمـات الإرهابية مـع حريـة التعبير في قضية ÖZTÜRK ضد تركيا سنة 999 و 9 حيث قضت المحكمة الأوربية لحقوق الإنسان بأن حرية التعبير من الحقوق الأساسية التي يتمتع بها الفرد وبصفة خاصة عندما يتعلق الأمر بنقد الحكومـة، وأن من أهم المجالات التي يتسع فيها هـامش تلك ارت

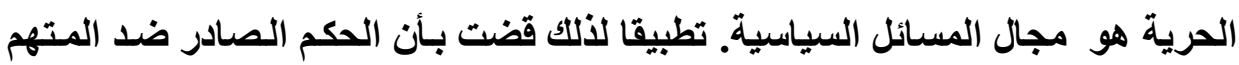
وهو ناشر قام بنشر كتاب تضمن سيرة ذاتية لزعيم من زعماء الحزب الثيوعي يشتمل على إبراز دوره وتمجيا سيرته والدعاية لهذا الحزب يخالف الحق في التعبير في مجال

= سرية أبوبكر الصديق في سوريا.- حركة الحوثيين في اليمن .- جيش محمد في باكستان

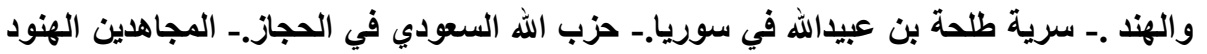

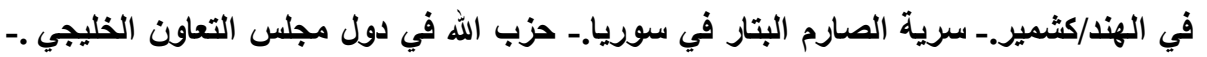

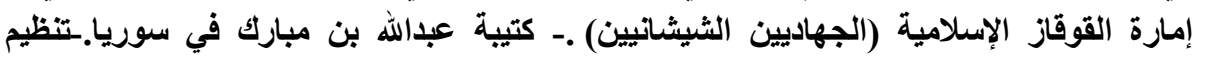

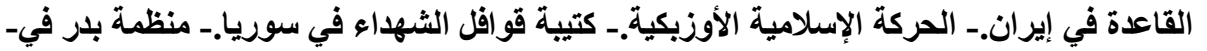

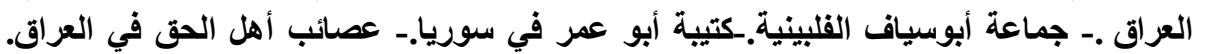

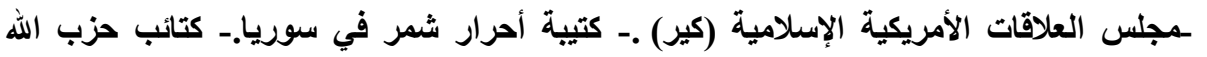

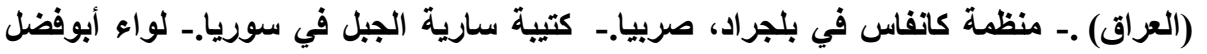

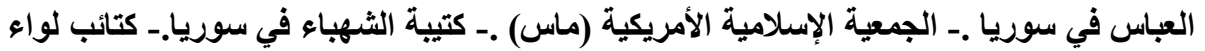

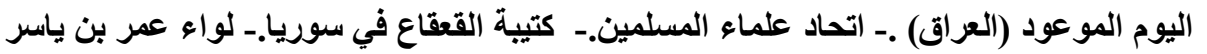

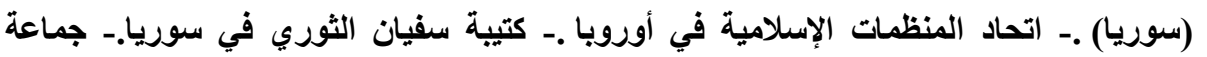

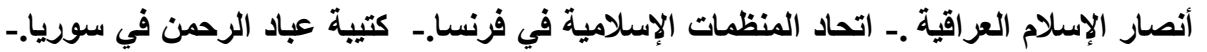

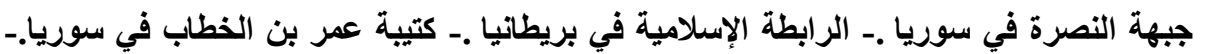

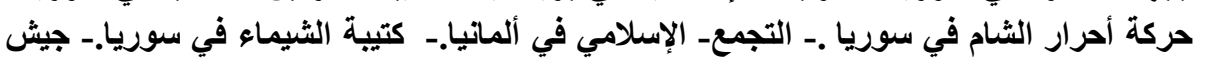

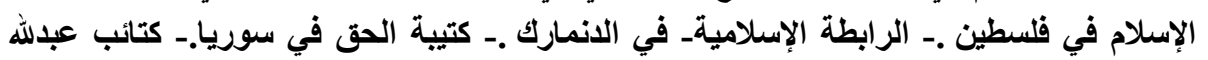
عزام .- الرابطة الإسلامية في بلجيكا (رابطة مسلمي بلجيكا). 
نقد الحكومات وبصفة خاصـة في المجـالات السياسية('). فلم تعتبر المحكمة أن هنـاك شيئا في الكتاب يتضمن تحريضا على ارتكاب الجرائم أو ممارسة العنف.

و إذا طبقتـا هذا الرأي في مجال تمجيد زعمـاء المنظمـات الإرهابيـة لوجدنا أن

الفـارق بين الوضعين كبيز، حيث إنـه على الرغم من اعتبـار القـانون التركي الحزب

الثيوعي منظمة إرهابية، فإن المحكمة الأوربية لـ تعتبره كذلك بسبب أنه لا يعدو أن

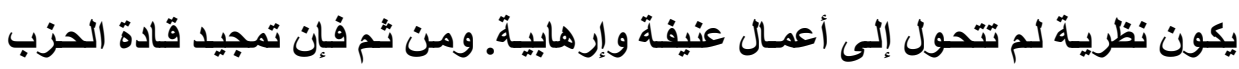
الثيوعي لا يمكن أن يرقى إلى تمجيد قادة "تنظيم الاولة الإسلاميةــ داعش".

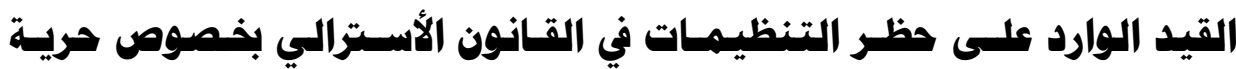

أقرت المحكمة العليـا الاستر الية في حكم Lange بـأن هنـاك قيودا ترد على

السلطة المخولة بإصدار القرار بحظر التظظيم بسبب التورط في الإرهـاب. وتتمثل هذه القيود في الإجابة على السؤالين التاليين: هل هذا القيد يشكل عبئـا على حريـة التعبير في المسائل السياسية بحيث يقيد حث الشخص في هذا التعبير أو في تكوين جمعيات لها دور في القيام بدور سياسي كالأحزاب مثلا. ويتمثل السؤال الثاني في: هل فرض هذا

القيد يبرره غاية مشروعة تتمشى مع أحكام الاستور؟؟( ). يلاحظ أن ذلك التحديد للمنظمة بأنها إرهابية يضع عبئـا غير مبرر على حريـة التعبير السياسية أحيانا، ويرجع ذلك إلى التالي:

(1) European Court of Human Rights, CASE OF ÖZTÜRK v. TURKEY, 28 September 1999

(2) Lange v Australian Broadcasting Corporation (1997) 189 CLR 520.

مجلتّ البحوث القانونيت والإقتصاديت مبr 
- أن التظيم يمكن أن يوصف بأنه إرهابي إذا صدر منـه استحسان أو موافقة على أفعال معينة، الأمر الذي لا يشكل في حد ذاته فعلا إرهابيا - إن التظيم يصدر قرار باعتباره إرهابيا إذا كان منسوبا إليه القيام بشكل مباشر أو غير مباشـر بعمـل مـن الأعمـال التي توصف بأنها إرهابيـة. ولـم يحدد القـانون الاتصال غير المباشر، الأمر الذي يشكل اتساعا منتقدا للسلطة التقديريـة لمصدر

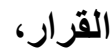
- إن القرار بوصف تنظيم معين بأنه إرهابي لا يصدر من القضاء ولكن يصدر من السلطة التتفيذية وهو ما يشكل إخلالا بـالحق في محكمـة كمـا يشكل مخالفة لمبدأ الفصل بين السلطات. - اسمها يشكل قانونـا يتضمن حكما قضائيا Bill of Attainder وليس عمـلا تثريعيا، الأمر الذي يسم العمل التثريعي بالتعفف والافتئات على وظيفة القضاء. فلا يكون للمحكمة عند الحكم على شخص معين بالانتمــاء إلى تلك المنظمـة أو بتقديم العون لها إلاّ التأكد من أن المنظمـة لهـا اسم معين، دون أن يتطرق إلى طبيعة الأفعال المنسوبة إلى تلكل المنظمة. - إن القانون الصادر باعتبار تنظيمات معينة تنظيمات إرهابية يتماثل مع ما سبق أن قضت بـه المحكمة العليـا باسـتراليا من عدم دستورية القـانون الصـادر باعتبـار الحزب الثيوعي في استراليا منظمة إرهابية، تدعو إلى استعمال العنف لسيطرة طبقة البروليتاريا على الحكم، ومن ثم وترتيب النتائج القانونية على ذلك( ').

(1) Australian Communist Party v Commonwealth, https://en.wikipedia.org/ wiki/Australian_Communist_Party_v_Commonwealth 
- -

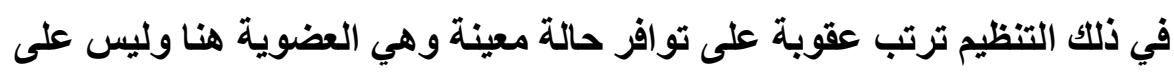
ارتكاب سلوك إجرامي معين.

- إن القانون أو القرار الصادر باعتبار تنظيم معين إرهابيـا وبالتالي وقوع جريمـة

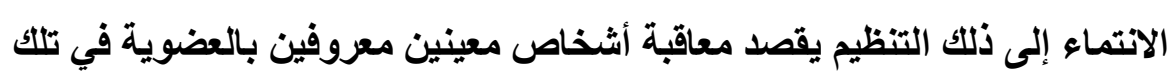
التنظيمـات وهو بالتتالي يتسم بالتعسف ويخـالف شرط العموميـة والتجريم التي دئي تتحلى بها القاعدة القانونية. - إن الجرائم المترتبة على اعتبار تنظيم معين تنظيما إرهابيا تقع بالعلم بأن التنظيم

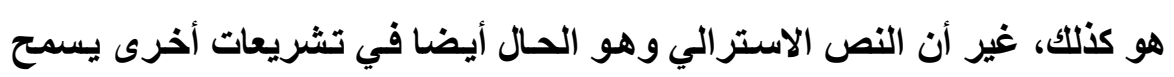
بوقوع تلك الجريمة بالإهمال وعدم الاكتراث في التحقق من أن التنظيم هو كذلك.

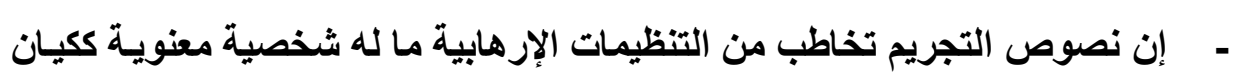

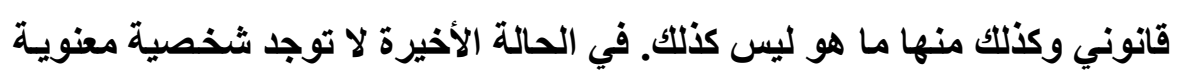

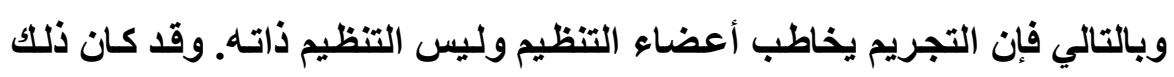
يستدعي التمييز بين الحسالتين في التجريم. كما أن اتجـاه التجريم إلى الأعضاء يؤدي إلى تجريم تقديم العون لهم كأن يقوم المتهم بتعليم أولادهم.

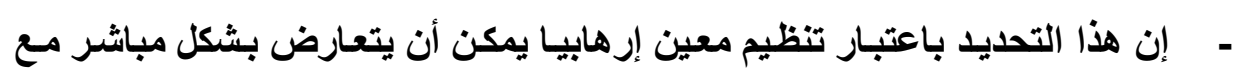

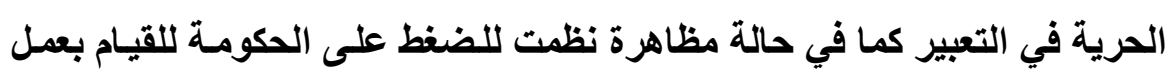

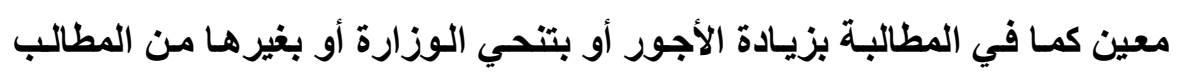

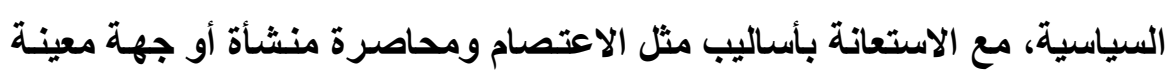

لمنع العمل بها.

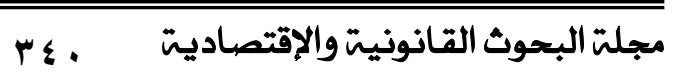


- إن ممارسـة السلطة المختصة بتحديــ التظظيمسات الإرهابيـة يتسم بـالتمييز في

المعاملة وآية ذلك أن الغالبية الساحقة من التظظيمات هي تنظيمات إسلامية.

- يصدر قرار باعتبار التظظيم إرهابيا على الرغم من أن نشاطه الأساسي نشاط

عادي ولكن جزءً هامشياً من نشاطه كان له علاقة بالدعوة إلى أو مساندة تنظيم

$$
\text { آخر له علاقة بالإرهاب }
$$

- يقع تحت طائلة التجريم بسبب صدور قرار باعتبار تنظيم معين تنظيما إرهابيا كل مـن يقدم عونـا ماديـا لهذا التنظيم ولـو كـان اللدعم مقدما لغايـة مشروعة كفتح

مدرسة للتعليم أو تبرع لعمل خيري لهذه المنظمة.

\section{هوقف القضاء الأهريكي هن دستورية تهديد التنظيسمات الإرهابية:}

اتجـه القضاء الأمريكي إلى أن اختصاص وزيـر الخارجيـة بتحديـ المنظمـات

الإرهابية لا يخالف الاستور الأمريكي، ولكن بشرط أن يحترم قواعد الاعوى العادلة بما تقتضيه من وجوب إعلان المنظمة بالقرار والاعتراف لها بالحق في الدفاع والحق في

(1) United States Court of Appeals, District of Columbia Circuit., PEOPLE'S MOJAHEDIN ORGANIZATION OF IRAN, Petitioner, v.UNITED STATES DEPARTMENT OF STATE and Madeleine K. Albright, Secretary of State, Respondents. Liberation Tigers of Tamil Eelam, Petitioner, v.United States Department of State, Respondent (1999),182 F.3d 17, $337 \quad$ U.S. App. D.C. 106: http://www.uniset.ca/other/cs5/427F3d646.html United States Court of Appeals, District of Columbia Circuit, NATIONAL COUNCIL OF RESISTANCE OF IRAN, Petitioner,v. DEPARTMENT OF STATE and Colin L. Powell, Secretary of State, Respondents (2004), F373 F.3d 152: http://uniset.ca/other/cs5/182F3d17.html

مجلتّ البحوث القانونيت والإقتصاديت ـب 
ويشكل ذلك عدولا عن اتجـاه سـابق للمحكمة العليا للولايـات المتحدة الأمريكية قضت بمقتضاه أن المسائل السياسية تدخل في أعمـال السيادة ويبعد القرار الإداري الصادر من رئيس الدولة من اختصاص القضاء(').

اتجهت أحكام القضاء الأمريكي إلى أن ما قرره المشرع الأمريكي من اختصاص وزير الخارجية بتحديل مـا يعتبر إرهابيا من المنظمـات لا يخـالف الاستور الأمريكي، مـادام أنـه التنظيم أجنبيا ومـادام أنه يظهر للوزير أن هذا التنظيم متورط في أنشطة 8 U.S.C. \& 8 إرهابية وأن هذه الأنشطة تهدد الأمن القومي الأمريكي وفقا للمـادة

$$
.\left({ }^{2} \cdot\right)(a)(1) \underline{1189}
$$

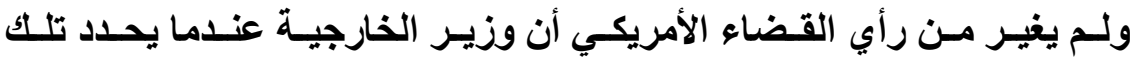
التنظيمات فإنه يعتمد على ملفات إدارية بعضها سرية لا يتم الإفضاء بها إلى المحاكم عند الطعن في قرار الوزير. ومع ذلك فِإن أحكام القضاء اتجهت إلى أن الإجراءات المتبعة تخـالف الدستور الأمريكي فيمـا ينص عليـه مـن ضمانة الـدعوى العادلة حيث لا يُعلن التظظيم المفنـي بالحظر بالقرار الصادر ضده عند صدوره ولا يطلع المسئولون عنه على الأدلة المقدمة

(1) U.S. Supreme Court C. \& S. Air Lines, Inc. v. Waterman S.S. Corp., 333 U.S. 103 (1948) Chicago \& Southern Air Lines, Inc. v. Waterman Steamship Corp. No. 78, 333 U.S. 103

(2) United States Court of Appeals, District of Columbia Circuit, NATIONAL COUNCIL OF RESISTANCE OF IRAN, Petitioner, v. DEPARTMENT OF STATE and Colin L. Powell, Secretary of State, Respondents, 2004, $\quad$ F373 $\quad$ F.3d 152:http://njlaw.rutgers.edu/collections/resource.org/fed_reporter/F3/3 73/373.F3d.152.htmNo. 01-1480. 
ضده من غير المشمولة بالسرية، ولا يتمكنون بالتـالي من مناقشة الأدلة المقدمة ضد

$$
\text { التنظيم('). (') }
$$

وللوزير أن يحدد أن المنظمات الإرهابية بما يشمل ذلك التنظيمات التي تقع تحت

سيطرة ورقابة المنظمة الأم أو الاشتراك في القيادة المشتركة. كمـا لا يغير من سلطة

$$
\text { الوزير أن يقوم التنظيم بتغيير اسمه أو عنوانه (r). }
$$

فقد قضت المحكمة العليـا للولايـات المتحدة الأمريكية ـ في قضية Scales - بـأن

تجريم مجرد العضوية في تنظيم معين محظور يخـالف الاسـتور، ذلـك أن السلوك المعاقب عليه غير محدد وبالتالي فِإن النص يعتبر غامضا وبنـاء عليه يخـالف مبدأ

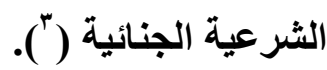

وترى المحكمة أنسه مـع ذلك لا يتعبن الحكم بـأن النص غير دستوري ولكن يتعين تفسيره بثكل لا يصطدم بالاستور بأن يتعين على المحكمة قبل الإدانة عن تلك الجريمة أن تتبين النشاط الذي يُنسب إلى العضو بـأن تكسون عضويته فعالـة ولـيس مجرد العضوية. وتحدد المحكمـة ذلـك بنـاء على وقـائع منسوبة إلى المـتهم في الـدعوة advocacy

(1) United States Court of Appeals, District of Columbia Circuit., PEOPLE'S MOJAHEDIN ORGANIZATION OF IRAN, Petitioner, v.UNITED STATES DEPARTMENT OF STATE and Madeleine K. Albright, Secretary of State, Respondents, id

(2) First National City Bank v. Banco Para El Comercio Exterior de Cuba, $\underline{462}$ U.S. 611, 103 S.Ct. 2591, 77 L.Ed.2d 46 (1983)

(3) Scales v. United States, 367 U.S. 203

مجلة البحوث القانونيت والإقتصاديت ب ع 
كمـا قضت المحكمـة بأنـه حتى لا يتعـارض تجريم تقديم الـدعم إلى التنظيم مـع

الحق في التعبير(') والحق في تكوين جميـات (التعديل الأول للاستور)(بَ) يتعين أن تستلزم المحاكم توافر قصد خاص يتمثل في نية مساعدة التنظيم الإرهابي في أنشطته الإرهابية. ولا يعتبر ذلك إضـافة للنص لم يتضمنها ولكن ذلك يُعد تفسير اللنص بمـا يتضمنه من معان من أهمها أن المتهم في تلك الجريمـة يعاون التظظيم على ممارسـة نشاطه الإرهـابي("). عندئــ فبان الحق في التعبير والحق في تكوين جمعيـات يتقيــ بمصلحة أعلى وهي مكافحة الإرهاب.

وقد سبق أن قضت المحكمة العليـا للولايـات المتحدة بـأن تقديم الدعم المسالي لجمعية من الجمعيات يشكل عنصرا من عناصر الحق في تكوين جمعيات الذي يضمنه

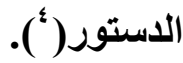

في حم Scales سنة الج 19 قضت المحكمة العليا للولايـات المتحدة الأمريكية بأن القـانون الصادر سنة ـ 19 والمسمى (قـانون الأمن الداخلي) والذي يجعل من

(1) McConnell v. Fed'l Election Comm'n, 540 U.S. 93, 124 S.Ct. 619, 157 L.Ed.2d 491 (2003) ; Nixon v. Shrink Missouri Gov't PAC, 528 U.S. 377,

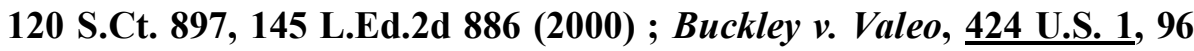
S.Ct. 612, 46 L.Ed.2d 659 (1976).

(2) Healy v. James, 408 U.S. 169, 182-83, 92 S.Ct. 2338, 33 L.Ed.2d 266 (1972)

(3) See Osborne v. Ohio, 495 U.S. 103, 119-22, 110 S.Ct. 1691, 109 L.Ed.2d 98 (1990).

(4) McConnell v. Fed'l Election Comm'n, 540 U.S. 93, 124 S.Ct. 619, 157 L.Ed.2d 491 (2003); Nixon v. Shrink Missouri Gov't PAC, 528 U.S. 377, 120 S.Ct. 897, 145 L.Ed.2d 886 (2000); Buckley v. Valeo, 424 U.S. 1, 96 S.Ct. 612, 46 L.Ed.2d 659 (1976)

مجلتّ البحوث القانونيت والإقتصاديت ع ع 
اكتساب عضوية الحزب الشيوعي في أمريكـا أو الاحتفــاظ بها جريمـة معاقبـا عليها جنائيا يخالف الدستور مـادام أن المقصود بالتجريم هو الحالة أي حالة كون المتهم عضوا. للتظلب على هذا العوار يكون بتفسير العضوية بأنها تتضمن القيام بنشاط معين وليس مجرد اكتساب أو الحفـاظ على تلك العضوية. فيكون إذن المقصود بالعضوية العضوية الفعالة حتى يكون النشاط المعاقب عليه محددا ولا يكون التجريم غامضا بمـا يعيبه من عدم الاستورية('). فإذا كان المتهم عضوا في الحزب الشيوعي الذي يدعو ضمن مبادئه إلى إسقاط نظام الحكم باستعمال وسـائل عنيفة، فإن مجرد عضويته قد يكون مجرد الاعتقاد في تلك المبادئ دون محاولة تتفيذها، وقد لا يكون متفقا مـع أفكار

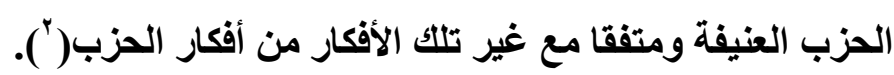
ومما يال على العضوية الفعال من جانب المتهم أنسه كـان يقوم بتدريس مبادئ الحزب العنيفة وأنه يحضر اجتماعاتها السرية وأنه كان يساهم بـالعون والمساعدة في تحقيق أغراضـها، ويساهم في تتظيم اجتماعاتها. أمسا مجرد حضور الاجتماعـات مسن

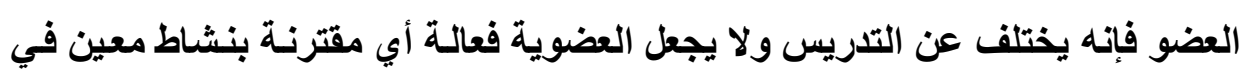
الاعوة إلى التنظيم. أما إذا كان يحضر اجتماعات التنظيم ويتعلم وسائله العنيفة وكيف يضعها موضع التنفيذ، فإن عضويته تكون فعالة)(").

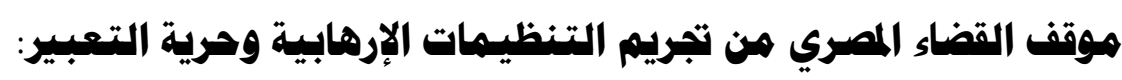

عبر القضاء المـصري عن رأيـه فـي أن تجـريم التنظيمـات الإرهابيـة يلـزم ألا يتعارض مع حرية التعبير، عندما قضى بأن الدعوة إلى العنف واتخاذ أفعال نحو تحقيق إتى

(1) U.S. Supreme Court, Scales v. United States, 367 U.S. 203 (1961)

(2) Dennis v. United States, 341 U. S. 494, 341 U. S. 499-500, (3) Yates v. United States, 354 U. S. 298. 
هذا الهوف يتحقق بـه معنى العضوية. في ذلك قضت محكمة النقض بأنسه "لمـا كاتـ الفقرة الأولى من المادة 9 أ من قانون العقوبات قد نصت على أنـه "يعاقب بالأشغال الثاقة المؤقتة (السجن المشدد حالياً) مدة لا تزيد على عشر سنين وبغرامة لا تقل عن مائسة جنيـه ولا تجـاوز ألـف جنيـه كل مسن انسشأ أو أسسس أو نظم أو أدار جمعيـات أو تنظيمات ترمي إلى سيطرة طبقة اجتماعية على غير ها من الطبقات أو إلى القضاء على طبقة اجتماعية أو إلى قلب نظم الدولة الأساسية الاجتماعية أو الاقتصادية أو إلى تحبيذ شيء مما تقدم أو الترويج له متى كان استعمال القوة أو الإرهـاب أو أيـة وسيلة أخرى الته غير مشروعة ملحوظاً في ذلك" فقد استهدف المشرع من وراء تأثيم الأفعال المشكلة لهذه الجريمة حماية السيادة الداخلية للاولة ضد خطر التظيم الهـام الذي يرمسي إلى المساس بالمبادئ الأساسية التي يقوم عليها('). فسياسة التجريم التي عبر عنها المشرع في تلك المـادة تنصرف إلى حمايـة المصالح الأساسية للاولة التي تقوم عليها سيادتها الداخلية ضد نوع معين من الاعتداء هو التنظيم الهـام أو الترويج لـه. ولكى يعتبر التنظيم مناهضاً يجب تـوافر شرطين، الأول يتعلق بالهـف والثانى يتعلق بالوسيلة. فبالنسبة للهدف أن يرمسي إلى سبطرة طبقة اجتماعية على غيرها من الطبقات أو إلى القضاء على طبقة اجتماعية أو إلى قلب إنى نظم الدولة الأساسية الاجتماعية أو الاقتصادية أو إلى هدم أي نظام من النظم الأساسية

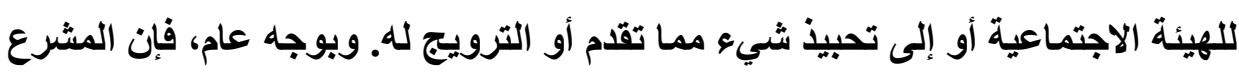
انصرف مـراده إلى حمايـة النظام الاجتمـاعي والاقتصادي للاولـة مـن خطر المـذاهب المتطرفة التي ترمي إلى بسط طبقة على أخرى وتحقيق ديكتاتورية البروليتاريا. 
وغنى عن البيان، أن هذه الأهداف يجب أن تتجاوز حدود النقد المباح الذي

شر عه الدستور وكفله القانون. وبناء على ذلك فإن ضبط منشورات لا تتضمن غير نقد الحالة السياسية والاقتصادية واتجاهات ذوي الثأن في حل مشكلات المجتمع في حدود النقد المبـاح ليس مـن شـأنه أن يرمسي إلى تحقيق أحد الأهداف التي أثمهـا القـانون. وبالنسبة للوسـيلة، أن يكون استعمال القوة أو الإرهـاب أو أيـة وسـيلة أخرى غير مشروعة ملحوظاً في ذللك. ولا يشترط لذلك أن يدعو التنظيم صراحة إلى استعمالها، وإنمـا يكفي أن يفهم ضمناً أن برنامجه وخطته التي يرمي إلى تحقيقها تقتضي بحكم اللزوم العقلي اللجوء إلى القوة أو إلى الإرهاب أو إلى أية وسيلة غير مشروعة، وأن تكون هذه الوسيلة من أهداف التظيم، فإذا كانت من آراء بعض أعضائه دون أن تعبر عن رأي التنظيم ذاتهـ فإن ذلك وحده لا يعتبر كافياً كما لا يشترط أن يبدأ التظظيم في استعمال هذه القوة أو تلك الوسيلة، بل يكفي التحقق من أن التظيم قد لاحظ هذه الوسيلة واعتمد عليها في تتفيذ أهدافه ولا يكفي لذلك أن ياعو التنظيم إلى إحداث تغييرات اجتماعية أو دستورية معينة ولو استعان في التدليل على قوة حججه ببعض تجارب الدول الأخرى أو إحدى النظريات ما لم يكن مفهوماً على سبيل المنطق أن تحقق هذه الدعوة يتوقف حتماً على استعمال

$$
\text { القوة أو الإرهاب أو أية وسيلة غير مشروعة معابل }
$$

ولألك فقد قضت هذه المحكمة ـ محكمـة النقض - "بأنسه إذا لم يستظهر الحكم أن الالتجاء إلى القوة أو الإرهـاب أو إلى أيسة وسيلة غير مشروعة كـان ملحوظاً في

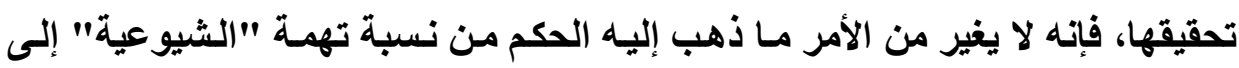
المتهم لأن ذكر هذا الاصطلاح ـ الذي لم تتضمنه نصوص القانون ولم يقرر له تعريفاً ـ 
لا يغتي عن بيان العناصر التي تتألف منها الجرائم التي استتل إليها الحكم في الإدانـة كما هي معرفة في القانون.

ولهذا فإن تصريح المتهمين بأنهم ماركسيون لا يصلح بذاته سنداً للقول بـأن مبدأهم هو استعمال القوة والعنف للوصول إلى هدفهم وإنمـا يشير فقط إلى اتجاهـاتهم

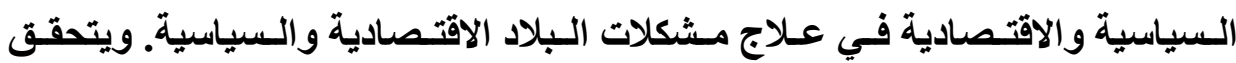
اسـتعمال القـوة بجميـع وسـائل العنـف المـادي على الأثـخاص أو التهديـــ باسـتعمال السلاح. كمـا يتحقق الإرهـاب بكافـة وسـائل الضغط الأدبـي أو الإتـلاف أو التخريـب أو تعطيل المرافق - ولا يشترط في الوسـائل الأخرى غير المشروعة أن تصل إلى حـ

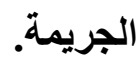

ولا يتطلب القـانون أن تكـون هـذه الوســائل هـي الطريـق الوحيـ لتنفيـ خطـة المنظمة الهـامة بل يكفي أن تكون من طرقها الأصلية أو الاجتماعية. ولمـا كـان الحكم المطعون فيه قد اتبع هذا النظر، فإنه يكون قد طبق القانون تطبيقاً صحيحاً"(').

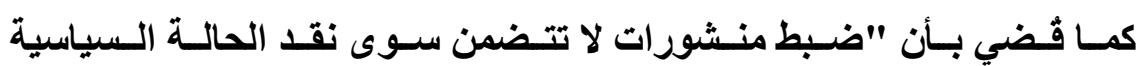
والاقتصادية واتجاهات ذوي الشأن في حل مشكلات المجتمع هو في حدود النقد المباح وأن وصف المتهمين أنفسهم بأنهم ماركسيون لا يدل على اتجاههم إلى استخدام القوة أو العنف لقلب نظام الحكم( ). فقد اتهمت النيابة العامة المتهمين بأنهم في دائرة قسم ثـان المنصورة انضموا إلى جماعة أسست على خلاف القانون الإرهابية الغرض منها الدعوة إلى تعطيل أحكام

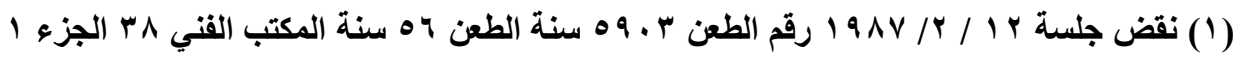

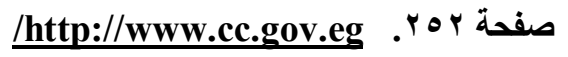

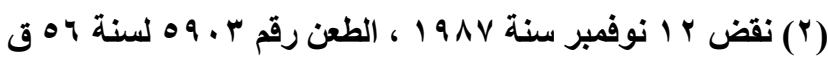


الاسـتور والقـوانين ومنـع مؤسسـات الدولـة وسـلطاتها العامـة مسن ممارسـة أعمالها وشـاركوا في الاعتــاء على الحريـات الثخـصية للمـواطنين وغيرهـا مسن الحريـات والحقوق العامـة التـي كفلهـا الدستور والقوانين وإضـراراً بالوحدة الوطنيـة والسلام الاجتمـاعي مـع علمهم بأغراضـها، وكـان الإرهـاب هو الوسيلة التي استخدموها في تحقيق تلك الأغراض على النحو المبين في التحقيقات. وذلك بالإضـافة إلى اتهامـات مرتبطة أخرى مثل التجمهر وحيازة أسلحة وذخائر، وكذلك تهمة روجوا بالقول وحازوا بالذات وبالواسطة محررات ومطبوعات تتضمن ترويجـا لأغراض الجماعة المنضمين إليها المبينة بالوصف الأول حال كونها تستخلم الإرهاب لتحقيق الأغراض التي تدعو إليها على النحو المبين بالتحقيقات(').

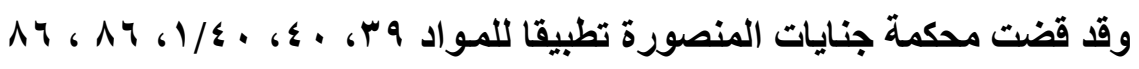

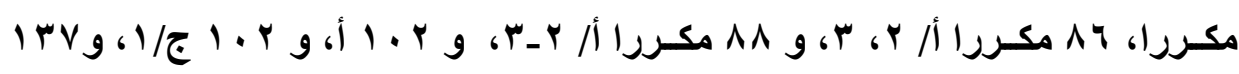

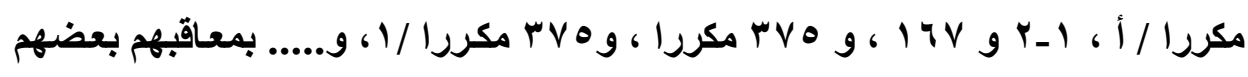
بالسجن ثُلاث سنوات والبعض الآخر بالسجن المشدد عشر سنوات والبعض الثالث بالسجن المؤبد.

غير أن محكمة النقض نقضث الحكم للقصور في التسبيب ـ في مـايو سنة ه 1 ـ ـ ـ ذلك أن الحكم قد دان المتهمين بجريمـة الانضمام التظيم إرهـابي وهو جماعة

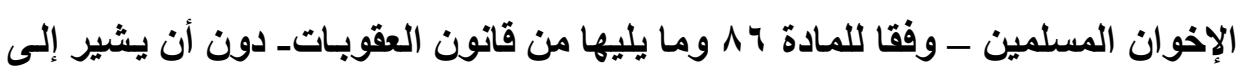
وجود تلك الجماعة في أسبابه وكيف أنها جماعة إرهابية وكيف انضم المتهمون إليها.

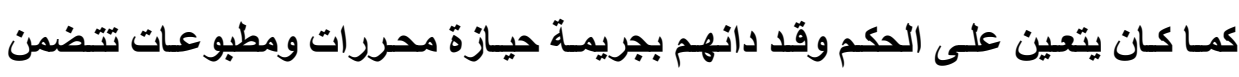
ترويجـا لأغراض تلـك الجماعـة ولـم يبين مضمونها ومـا حوتـه مـن عبـار ات وألفـاظ 
للوقوف على مدى مطابقتهـا للأهداف المؤثمـة قانونـا ومـا إذا كانت تلكـ المطبوعـات والمحررات معدة للتوزيع أو لاطلاع الغير عليها. كما أن الحكم المطعون فيه قد اقتصر في التـليل على اقتراف الطـاعنين لجريمـة "الانـضمام لجريمـة الإخـوان المسلمين الإرهابية على مـا حصله من أقوال الضابط ... بـالأمن الوطني من أن تحرياتـه أكدت انضمامهم سـالفة الذكر دون أن يـورد في هذا الخصوص دليلا يعزز هذه التحريـات ويسندها. لمـا كـان، ولئن كـان لمحكمة الموضوع أن تعول في تكوين عقيدتها على التحريات باعتبار ها معززة لما ساقته من أدلة، إلا أنها لا تصلح وحدها لأن تكون دليلا

بذاته أو قرينة بعينها على الواقعة المراد إثباتها. وقد كان العوار الذي شـاب الحكم السابق هو ذاته مـا انتهت محكمـة النقض إلى توافره في حكم سابق لها من نفس العام، عندما نقضت حكما صـادرا ضد مجموعة من الصحفيين كانوا يغطون أخبار الأحداث غداة ـ ب يونيه، مبينين التذمر الشعبي ضد تلخل الجيش ومستعينين بوسائل التقتية الفنية في عمل مونتاج لمـا يتلقونـه من أفلام عن الأحداث لبيان التذمر الشعبي في رأيهر. من تلك الأحداث تغطية أحداث رابعة التي تضمنت إذاعة صور كاذبة عن العنف الشرطي وقتل المتظاهرين السلميين في رأيهم. وقد أسندات النيابـة العامـة لهم تهمـة الانضمام لجماعـة الإخوان المسلمين. وقد جـاء نقض محكمة النقض لهذا الحكم على سنـا من أنـه لـم يبين واقعة انضمامهم لجماعة الإخـوان المسلمين. كمــا أن الحكم لــ يــلل على وجـود جماعـة الإخـوان المسـلمين والغرض من تأسيسها قبل انضمامهم إليها، وكيفية انضمامهم إليها وعلمهم بـالغزض من تأسيسها التي دان الطاعنين بها. كما أن محكمة النقض عابت على الحكم أنه إذ دان الطاعنين بجريمة حيازة مطبوعات وتسجيلات تتضمن ترويجا لأغراض الجماعة دون 
أن يعنس بيـان مـا إذا كانـت المطبوعـات والتسجيلات معدة للتوزيـع أو لاطـلاع الغير

عليها (') (1)

\section{اعتراضات دستورية على آلية تحديد المنظمة بأنها إرهابية:}

مـن مراجعـة كثير مـن النصوص القانونيـة المقارنــة يتضـح أن هنـاك شكوكا

دستورية حول مبدأ الفصل بين السلطات حيث تقوم السلطة التنفيذية بعدل من طبيعة قضائية وهو الفصل فيمـا إذا كانت منظمـة معينة تعد إرهابيـة. فهو ليس عمـلا إداريـا محضا. كما ينتقد هذا النظام بسبب غياب القواعد والمعايير التي يتم بنـاء عليها تحديد منظمة معينة على أنها إرهابية. يضاف إلى ذلك ما ينطوي عليه هذا العمل من الإخلال بالحق في التعبير والحق في الاجتماع وتكوين جمعيات والتي يجب أن تثبت حالة من الحالات التي يجوز فيها تقييد تلكك الحقوق، وليس إقامة ذلك الإخلال على ظنون وأخبار قد تكون غير مؤكدة، وتنتمي إلى الشهادات السماعية.

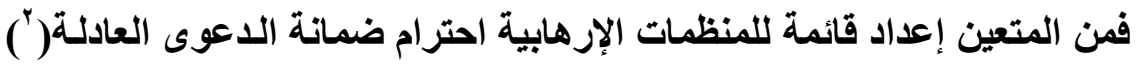
والتي تضضن الحق في الدفاع والطعن في قرار التسجيل أمسام القضاء أي ضـمانة القضائية)(r). مسن التحـيات للحق في الدفاع عند تسجيل تنظيم معين على قائمــة التنظيمات الإرهابية أن التسجيل كثيرا ما يعتمد على معلومات جهة الاستخبارات وهي

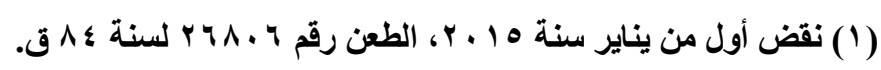

(2) Cour de Justice de Communité Européenne, 3 sept. 2008, aff. C-402/05 P, Kadi et internationa Al Barakat Founation ; CJUE, gr. ch., 18 juill. 2013, aff. jtes C-584/10 P, C-593/10 P \& C-595/10 P

(3) CA Paris, Pôle 8, ch. 1, 22 févr. 2012, Juris-data $n^{\circ}$ 2012-009372; le pourvoi formé contre cet arrêt a été rejeté par Crim., 10 avr. 2013, ${ }^{\circ}$ 12-82.088, inédit.

مجلت البحوث القانونيت والإقتصاديت 
checks معلومات سرية(') وذللك كله يقتضي إيجاد نوع من التوازن في السلطات aتقريـر حـق الجهـة الإداريـة أو النيابـة العامـة فـي الإدراج وحق and balances المضرور في الطعن(r) (r) (r). r Y ـ عدم احترام قواعد اللدعوى العادلـة عــــ تعيين المنظمـة الإرهابيـة في القـانون

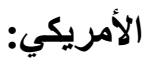

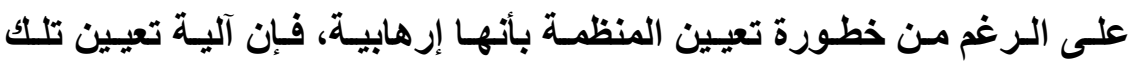
المنظمة لا تحترم قواعد الاعوى العادلة، وذلك للأسباب التالية: - يقوم وزير الخارجية بالتشاور مع وزير المالية (بتحديد أن المنظمة إرهابية بدون إخطار مسبق لها(").

- يقوم الوزير بذلك التحديد دون سماع المسئولين عن المنظمة. - يتم ذلك التحديد دون جلسة علنية - يتم ذلك التحديد دون وجاهية في الإجراءات. - - لا يسمح للمسئولين بتقديم ما يفيد بأنهم لا يقومون بأعمال إرهابية.

(1) Crim., 3 sept. 2014, $\mathrm{n}^{\circ}$ 11-83.598, inédit ; O. Cahn, Procès équitable : la France tend à nouveau les verges à la Cour européenne des droits de l'homme, AJ pénal 2014. 577.

(2) OSCAR Roos, BENJAMIN HAYWARD \& JOHN MORSS, Beyond the Separation of Powers: Judicial Review and the Regulatory, Proscription of Terrorist Organisations, 35 U.W. Austl. L. Rev. 81 2010-2011, http//Heinonline.org

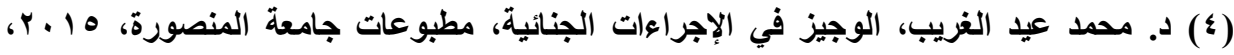

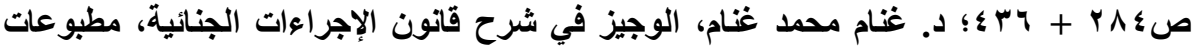

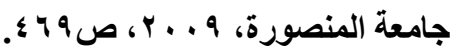

(4) Id 
- المنظمة لها أن تتظلم من قرار تعيينها إرهابية في خلال ثلاثين يوما فقط

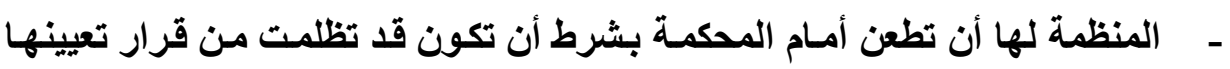

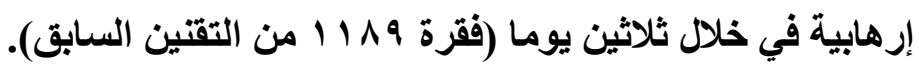

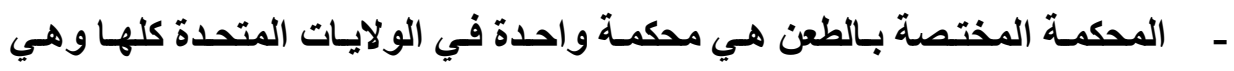
محكمة استثناف منطقة كولومبيا. - تنحصر سلطة محكمة الاستئناف في مراجعة قرار تعيين المنظمة في أوجها محددة

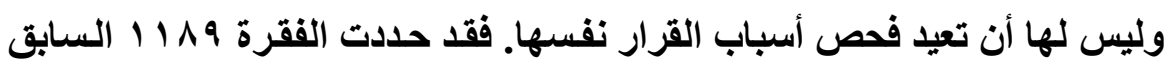

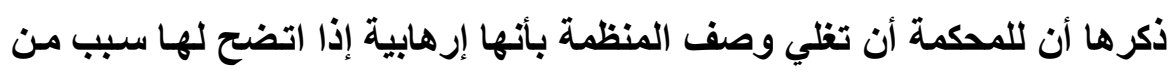

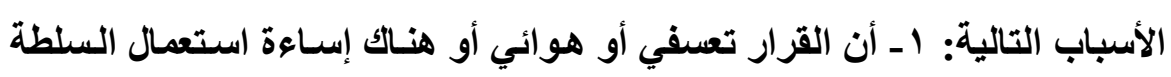

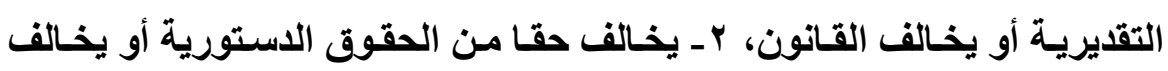

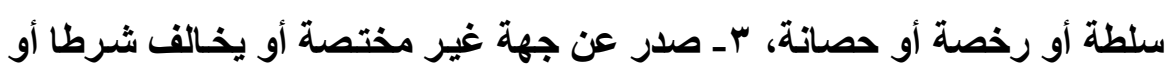

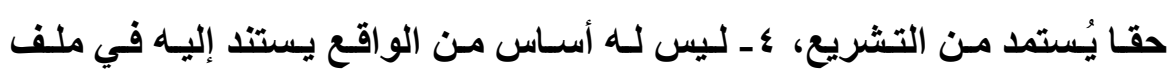
الدعوى، هـ يخالف ما يأمر به القانون من وجوب اتباع إجراءات معينة.

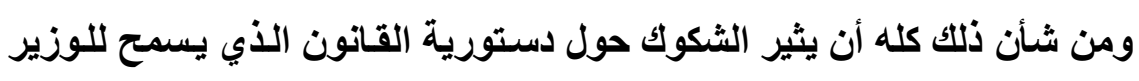

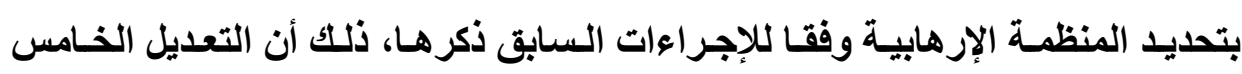

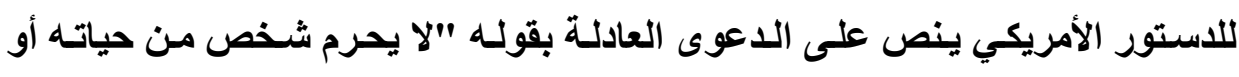

$$
\text { حريته أو أمواله بدون دعوى عادلة". }
$$

من صياغة التعديل الخامس للاستور الأمريكي يتضح عأنه لكي يتمتع الشخص

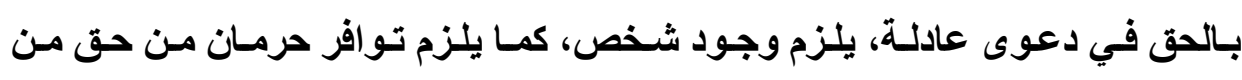
الحقوق الواردة في هذا التعديل. 
ومن ناحية تعريف الثخص، فإنه لا ينحصر في الشخص الطبيعي ولكنه يشمل

الشخص المعنوي أيضا، حتى ولو كان غير جهة أو كيانـا غير مشهر قانونـا. المهم أن يكون لله تواجد مادي على إقليم الولايات المتحدة) ') أو يمتلكك أموالاً فيها، ويكفي أن يكون له حساب في بنك أمريكي حتى يتمتع بـالحق في دعوى عادلة، وسواء أكاتـ المنظمة أمريكية أو أجنبية(؟). غير أنه قضي بأنه لا يكفي أن يكون لعضو من أعضاء هذا التظظيم أموال أو يكون له حساب في بنك أمريكي، بل يجب أن يكون للمنظمة ذاتها هذه الأموال أو ذلك الحساب("). وفي حالة عدم توافر هذا الثرط، فإن المنظمة لا تتمتع بالحمايـة المقـررة في التعـديل الخـامس ولكـن ذلــك لا يحـول دون تمتعهـا بمـا تقرره

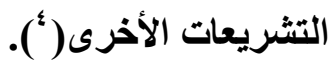

ولكي يمكن الحكم على الدعوى إذا كانت عادلة أو غير عادلة أقرت المحكمة العليـا للولايـات المتحدة الأمريكية ـ في حكم مـاتيو Mathews سـنة 9 \ 19 ـ معايير ثلاثة يجب أخذها في الاعتبار وتحقيق التوازن بينها. الأول يلزم توافر مصلحة للفرد، الثاني توافر احتمال حدوث خطأ في الإجراءات، الأمر الذي يستلزم توفير قاضي طبيعي والمواجهة بالتهمـة وتمكين المتداعي مـن الدفاع ومـن الطعن أيضا، والثالث تـوافر مصلحة للمجتمع في أن التخفيف يعد من الضمانات الإجرائية التي يجب أن يتمتع بها

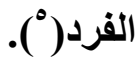

(1) YickWo v. Hopkins, 118 U.S. 356, 369 (1886).

(2) Sardino v. Federal Reserve Bank of N.Y., 361 F.2d 106, 111 (1966)

(3) S County Sovereignty Comm. v. Dep't of State, 292 F.3d 797

(4) People's Mojahedin Org. of Iran v. U.S. Dep't of State ("PMO'), 182 F.3d 17, 23 (D.C.Cir. 1999)

(5) $M$ athews v. Eldridge, 424 U.S. 319, 334 (1976).

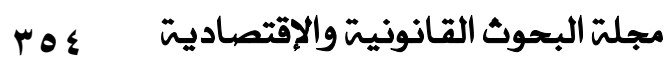


وقد سبق أن أكدت المحكمة العليا للولايات المتحدة الأمريكية أن متطلب الدعوى

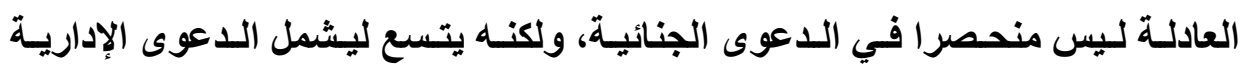

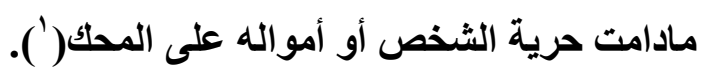

غير أنه بمراجعة إجراعات وصف المنظمة بأنها إجرائية يتضح أنها لا تتمتع في

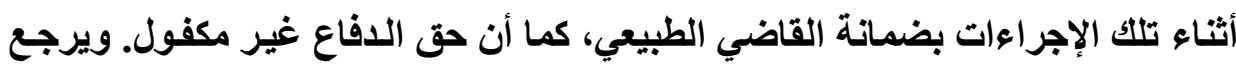
ذللك إلى عدم إخطارها بالإجراءات وعدم علمها بالتهمة وعدم تمكينها من تقديم أوجها

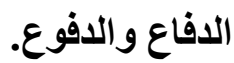

فضمانة القاضـي الطبيعي لا تتوافر حيث تقوم جهـة تنفيذيـة بتحديد ركن من

أركان الجريمة وهي أن المنظمة إرهابية، كما أن الوزير الأي يقوم بهذا الوصف يجمع لهمع

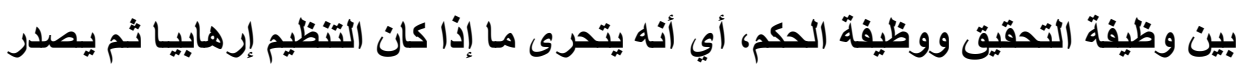

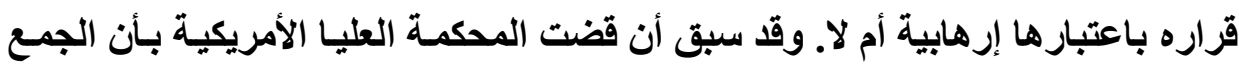

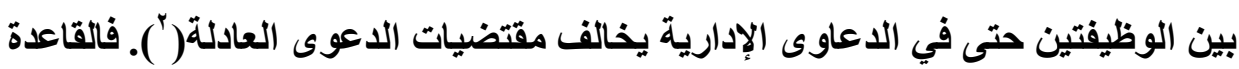

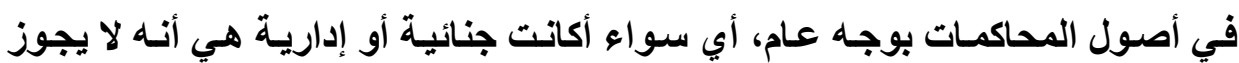

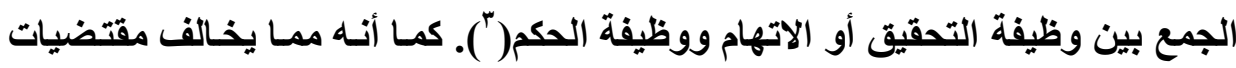

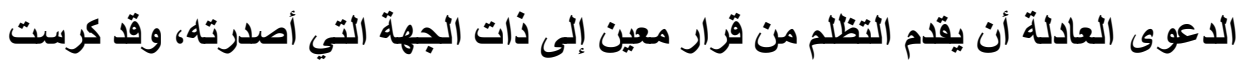

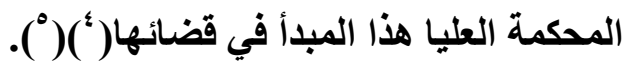

(1) G irard v. Klopfenstein, 930 F.2d 738, 742 (9th Cir. 1991); Withrow v. Larkin, 421 U.S. 35, 46 (1975).

(2) Withrow, 421 U.S.58

(3) راجع : د. فهز نشمي الخرينج الرشيدي، مفهوم المحاكمة العادلة في قضاء المحكمة الأوربية

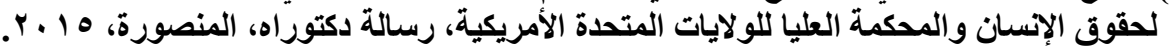

(4) Walker v. City of Berkeley, 951 F.2d 182, 184 (9th Cir. 1991)

(5) Brown v. State Bd. of Dental Examiners, No. 93A-1-017, 1994 WL 315304 (Del. Super. Ct. May 23, 1994); see also Gagnon v. Scarpelli, 411 U.S. 778 (1973); Morrissey v. Brewer, 408 U.S. 471 (1972).

مجلة البحوث القانونيت والإقتصاديت مهر 


\section{ضرورة كفالة حق التنظيم في هحاكمة عادلة:}

تلجأ كثير من الدول إلى النص في قوانينها على إعداد قائمة للإرهاب تتضمن أثخاصا أو منظمات تتصف بالإرهاب وثُعامل بهذا الوصف. وقد وضعت الأمم المتحدة

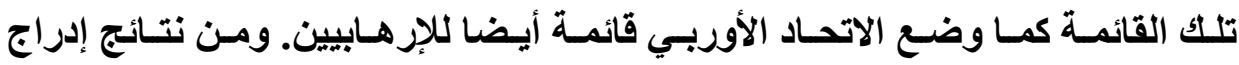
الأشخاص أو المنظمـات على قائمسة الإرهـاب أن يتم حظر التعامل معهم كمـا في حالـة السفر إلى الخارج ويتم مخاطبة الدول للقبض عليهم وتقديمهم إلى المحاكمة، كمـا يتم

$$
\text { تجميد أرصدتهم في البنوك والمصارف. }
$$

وقد أثثر مدى حق الثخص أو المنظمة المدرجة على قائمسة الإرهاب في العلم

Organisation des Modjahedines du بأسباب إدراجها فـي قضية peupled'Iran v. Council and UK (OMPI)

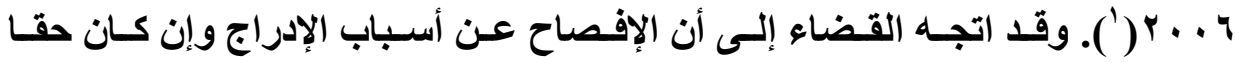
للشخص المدرج اسمه، فإنه ليس من حقه الاطلاع على الأدلة التي استدعت اتخاذ قرار الإدراج، وذلك لتطقى الأمر بمطومسات سرية تقتضي عدم الكشف عنها لتعلقها بأمن الـدول ولخطورة الكشف عنهـا بسبب وجـود تخـوف معقـول للانتقـام مـن مـصدر

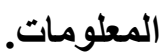

وقد أيد القضاء الهولندي (محكمة CFI) سنة ج . . . . ومحكمة العدل الأوربية. في قضية Sison سنة V . . Y.- أن من حق من تم وضعه على قائمة الإرهاب أن يتمتع

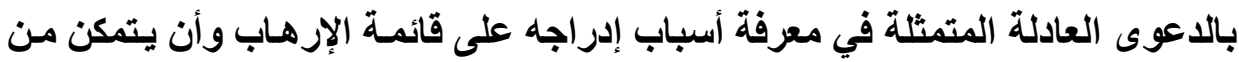

(1) Eckes, Christina, Case T-228/02, Organisation des Modjahedines du Peupled'Iran v. Council and UK (OMPI), Judgment of the Court of First Instance (Second Chamber) of 12 December 2006 [case], Common Market Law Review, Vol. 44, Issue 4 (August 2007), pp. 1117-1130 
مناقشة تلك الأسباب وأن يطعن على قرار وضعه على تلكك القائمسة أمسام القضاء. ومـع ذللك أكد القضاء أن للاولة عند الطعن على قرار الوضـع على قائمسة الإرهـاب ألا تفصح عن مصدر المعلومات التي تؤيد تورط تنظيم معين في الإرهـاب، استنادا إلى اعتبارات تتعلق بـالأمن القومي. ولا يعتبر ذلك مبررا للقول بوقوع مخالفـة للحق في دعوى الته

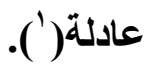

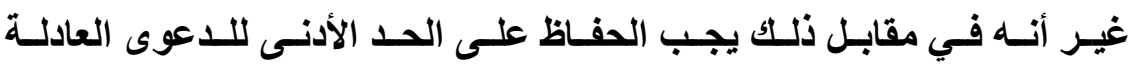

والذي يقتضي حق الشخص المسارج في مناقشة أسباب إدراجـه دون الكشف عن مصدر تلكك الأسباب. وقد قضت بذلك المحاكم الأوربية بخصوص إدراج منظمة مجاهدي خلق على قائمـة الإرهـاب على الـرغم مـن أن الأمسم المتحـدة قــ أدرجتهـا على تلـك القائمة. وبناء عليه فإن المدرجين على القائمة الأوربية من حقهم أن يحذقوا أسماءهم

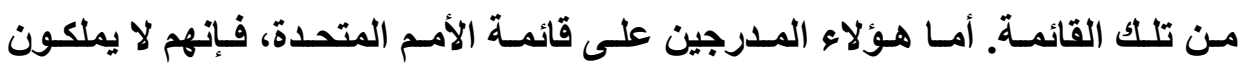

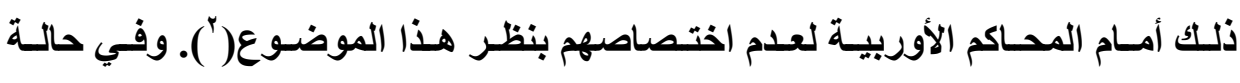
الإدراج المزدوج بين القائمتين لنفس الاسم، يستعيد الشخص حقه في الطعن وطلب

(1) (Cases T- 110, 150 and 405/03, judgment of 26 April 2006) and the European Court of Justice (ECJ) (Case C-266/05 P, judgment of 1 February 2007): BRIAN SLOAN, FREEZING TERRORIST ASSETS AGAIN: WALKING A TIGHTROPE OVER THIN ICE?, 67 Cambridge L.J. 31 2008: http://heinonline.org.

(2) ANGUS JOHNSTON, FREEZING TERRORIST ASSETS AGAIN: WALKING A TIGHTROPE OVER THIN ICE?, 67 Cambridge L.J. 31 2008 : http://heinonline.org 


\section{ضرورة إقرار الحق في الطعن على قرار إدراج المنظمة على قائمة الإرهاب:}

على الرغم مما هو متفق عليه أن الحق في الطعن من عناصر الدعوى العادلة،. فإن الطبيعة القانونيـة لقرار الإدراج على قائمـة التنظيمـات الإرهابية تؤثر في تحديد جهة الطعن: هل هي القضاء الإداري باعتبار أن هذا القرار صادر من سلطة إداريـة؟ أو الو هل هي جهة القضاء العادي باعتبار أن الأمر يتعلق بتحديد شرط مسبق في كثير من

$$
\text { الجرائم منها الانتماء إلى تنظيم إرهابي؟ }
$$

يخفف من عمق تلك المشكلة أن الحق في قاضسي أو الحق في محكمة يتوافر

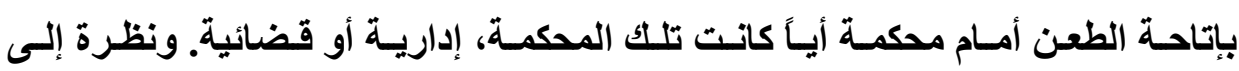
التشريعات المختلفة نجدها تختلف في التفاصيل ولكنها في النهايـة تحترم الحق في محكمة. فالقانون الإنجليزي يسمح بالتظلم أمسام لجنـة خاصـة ذات طبيعة قضائية ولكن مع كفالة الحق في استئناف قرار اللجنة أمام القضاء العادي وكذا القانون الكندي الذي يطبق المبـادئ العامـة في الحق في قـاض('). وقد اختـار القـانون المصري في شـأن الكيانات الإرهابية أن يتيح الحق في الطعن مباثرة أمسام القضاء مـع تحديد أن الجهة المختصة هي القضاء العادي.

وبنـاء عليـهـ فـإن التشريعات المختلفـة لا تميـل إلـى إعطــاء القـضاء الإداري الاختصاص بنظر الطعن في قرار الجهة الإداريـة أو النيابة العامـة بـإدراج تنظيم معين على قائمة الإرهاب، على الرغم من أن ذلك القرار صـادر من جهة إداريـة وبالتالي قد يبدو ذات طبيعة إداريـة. وواضـح أن التشريعات على اختلاف مشاربها قد أدركت أن

(1) Charkaoui v. Minister of Citizenship and Immigration, (2007) SCC 9, http://www.shk.ca/docs/CharkaouiMinsterCitizenshipandImmigration.p df, p. 7. 
طبيعة القرار ليست إداريـة بحتـة وإنـه يتخلاهـا عناصر قضائية مهمـة حيث أن الأمر يتعلق بشرط مسبق في الجريمة أي يتعلق بنزاع قضائي عادي ووقوع جريمـة وليس مجرد البت في مسألة إدارية.

وعلى أية حال فإنه يحد من الحماية القانونية لحق المنظمة في الدعوى العادلة

أن سلطة محكمة الطعن في مراجعة القرار الصادر بتعيين المنظمة الاعتبارات التالية: - عدم الظلط بـين الطعن في اللائحسة التـي تـنظم سـلطة الجهـة المختصة بتعيين المنظمة وبين الطعن في القرار الصادر بتعيين منظمـة معينة؛ فالطعن يكون في

$$
\text { القرار الإداري وليس في اللائحة. }
$$

- المختصة عند تعيينها التنظيم بأنها إرهابي. ويمتد ذلك في دول الكومنولث إلى جذور له في القانون العرفي common law بسبب ما اعتنقه من مفهوم لـه في الفصل بين السلطات: السلطة القضائية والسلطة التنفيذية. بل إن هنـاك نوعا من الحصانة لبعض الموظفين تأثر بهذا الاتجاه حتى لا يتذخل القضاء في عمل السلطة التنفيذية. - تردد المحسكم في مراجعة القرار بتعيين المنظمـة بسبب اعتبـارات حمايـة الأمن القومي. - عظر بعض القوانين المقارنة على الخصوم إفشاء المعلومـات التي تثعلق بـالأمن القومي، كما هي الحال في استراليا. وفقا لقانون المعلمات المتعلقة بالأمن القومي في الدعاوى المدنية والتجاريـة لسنة ؛ . . ب في استراليا ـ على الخصوم- في الــاعاوى المدنيـة والتجاريـة ــ أن يطلبـوا إلـى المحسامي العـام ترخيـصا بإفشاء 
معلومات تتعلق بالأمن القومي. وهو يقدر ما إذا كاتت تلك المعلومات تتعلق بالأمن العام أو لا تتعلق. كما أن لله بمبادرة منه أن يصدر بيانا بعدم الإفشاء. كما أن له أن يحظر على شـاهد أن يـلي في بشهادته بمعلومـات تتعلق بـالأمن القومي، عندئذ تلتزم المحكمة بعقد جلستها في غير علنية('). وحماية لتلك الأسرار القومية، فِان المشرع الاسترالي نص- في الفصل 7 ؛ من القانون سابق الأكر-على عدة جرائم، منها: - علدم إخطار خصم في دعوى مدنية بأن لايـه معلومـات تتعلق بـالأمن القومي وهو يتوقع أنها كذلك. - قبل أن يعطي موافقته. - دعوى خصم لشـاهد إلى المحكمة قبل أن يعطي المحامي العام موافقته وكـان الأمر متعلقا بالأمن القومي

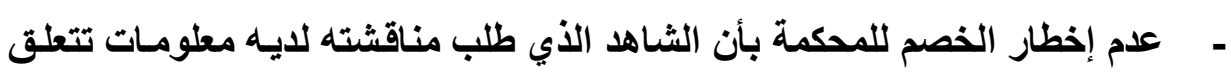
بالأمن القومي يتوقع أن يالي بها - إفثاء معلومات في قضية مدنية بينما هي تهم الأمن القومي بالمخالفة لما أمر بـه المحامي العام، - وعلى الرغم مـن أن هنـاك مبررا قويـا للإسـراع في إجراءات تعيين المنظمـة

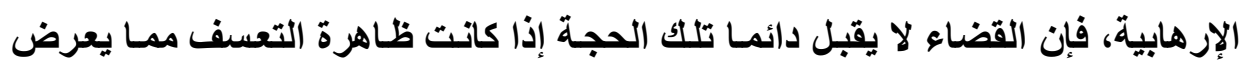

(1) The National Security Information (Criminal and Civil Proceedings) Act 2004 (Cth) ('NSI Act') 
الحرية الفردية للغير أو ممتلكاته للحرمان كما هي الحال عند تعيين المنظمـة على أنها إرهابية، فتجمد أموالها ويتعرض أعضاؤها بل ومن يتعامل معها لعقوبة الحبس. تطبيقا للألك قضت المحكمة العليا بالمملكة المتحدة في قضية ل بخصوص خمسة أشخاص تم حبسهم على سند من أنهم Home Department يمثلون خطورة للأمن القومي، وقد طلبت انجلترا من المجلس الأوربي منحها استثناءً من الضمانات التي تقررها الاتفاقية الأوربية لحقوق الإنسان بسبب الظروف التي كانت تمر بها في وقت أحداث القضية. طعن الأثخاص الخمسة في طلب الحكومـة البريطانيـة هذا وتمسكت سلطاتها بأن الأمر يتعلق بالسلطة التقديرية التي تملكها الإدارة عند تقرير الاعتبارات المتعلقة بالأمن القومي. رفضت المحكمة العليا البريطانيـة هذا الدفع على سـند تعـارض ذلـك مـع مـا يقتضيه القـانون في بلـلـ ديمقراطي مـن صـيانة الحقـوق والحريـات. وينـاء عليه قضت المحكمة بعدم دستورية الفصل بr من قـانون مكافحة الإرهاب في بريطاتيا لعام l . . ب الذي يجيز للملكة طلب استثناء لحبس الأشخاص في تللك الحالة دون توجيه اتهام معين لهم('). وتأكياً لحق المنظمة في الطعن، أكلد المحكمة العليا لأستر اليا مبدأ أنـه يجب إقامـة التوازن بـين اعتبـارين متناقضين؛ الأول وهو حمايـة الأمسن القومي أي حمايـة للمجتمـع مـن الإرهـاب والثاني هـو حمايـة حقوق الأفر اد وحريـاتهم. ومـع ذلكـ فـان المحكمة أعطت الأولوية للنوع الأول من الاعتبارات(r). كمـا قضت محكمة فرنسية ـ في قضية مجاهدي خلق الإيرانية ضد المجلس الأوربـيـ أن مـن حـق المنظمـة أن تطعن في القـرار الـصادر مـن المجلس الأوربـي

(1) A v Secretary for the Home Department [2005] 2 AC 68, 85. 1 (2) Leghaei v Director-General of Security [2007] HCA Trans 655. 
باعتبارها من المنظمات الإرهابية أمام أي محكمة من محاكم المجموعة الأوربية، وذلك بـالتزامن مـع طعنها في القرار الصادر بتجميد أموالها وأنها من حقها أن تطلع على الأسباب التي حدت إلى اعتبارها إرهابية. لذا فإن من حقها الطعن على هذا القرار أمسام محكمة أي جهة قضائية إعمالا للحق في دعوى عادلةة(')، الأمر الذي يقتضي الكشف عن تلك الأسباب حتى يمكن ممارسـة ذلك الحق. وفي حالـة وجـود أسباب تقتضي مصلحة قومية عدم الكشف عنهـا يلزم أن يكون هنـالك مـن تبريـر لحرمانها مـن هذا

ويسأتي هذا القضاء على خلاف مـا قضي بـه في قضية Yusuf and Al

Barakaat International Foundation v Council and Commission [2005] حيث ثضي بأنه ليس من حق الصادر في حقه قرار باعتباره إرهابيا أن يطعن على هذا القرار مع ما يستوجب ذلك من اطلاعه على الأسباب التي دعت إلى وضعه على قائمـة الإرهـاب. ويرجع الاختلاف في القضاء إلى أن القرار في قضية and Al Barakaat International Foundation

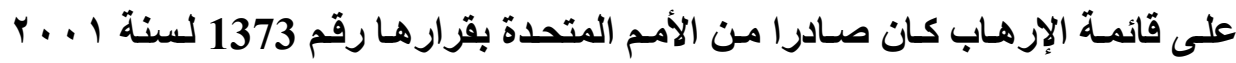
وليس مـن المجلس الأوربي. ومـؤدى ذلكـ أن القرار كـان مفروضــا على المجموعـة

(1) Case 24/62 Germany v Commission [1963] ECR 63, 69; Case C-400/99 Italy v Commission [2005] ECR 1-3657, paragraph 22; Joined Cases T346/02 and T-347/02 Cableuropa and Others v Commission [2003] ECR 11-4251, paragraph 225)

(2) Organisation des Modjahedines du peupled'Iran V Council of the European Union, Judgment of the Court of First Instance (Second Chamber), 12 December 2006 II - 4674 , Case T-228/02, 2006-1112 A E.C.R. II-4665 2006 , http://heinonline.org/HOL/License 
الأوربية أي أن الأمر تعلق بسلطة مقيدة circumscribed power. ويختلف الأمر

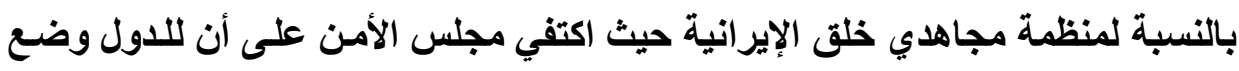
الإرهابيين على قائمة الإرهاب مع مـا يترتب على ذلك من عدم التعامل معهم وتجميد

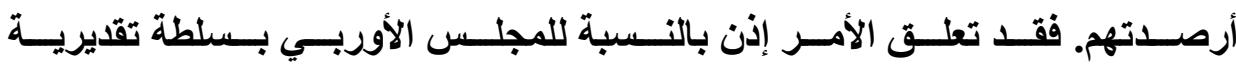

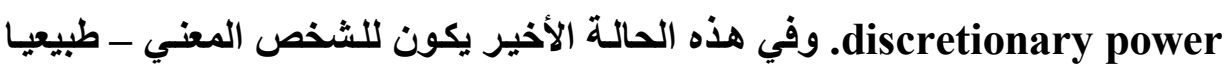

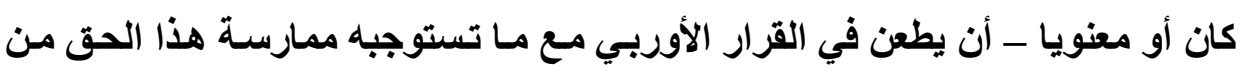

$$
\text { الكثف عن أسباب وضعه على قائمة الإرهاب( ('). }
$$

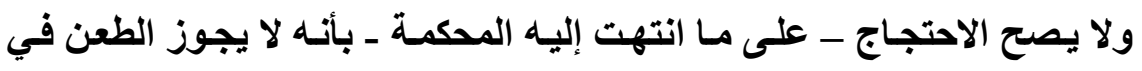

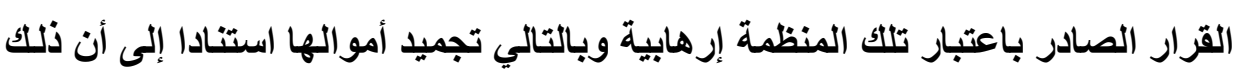

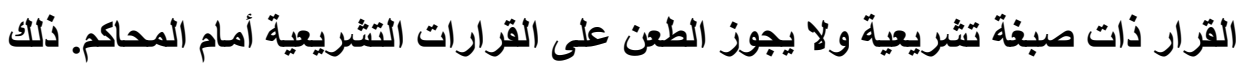

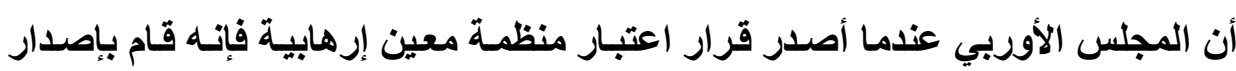

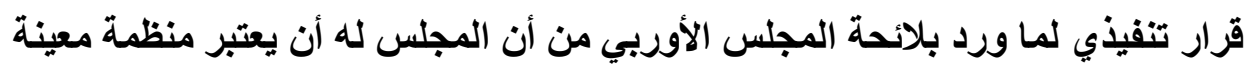

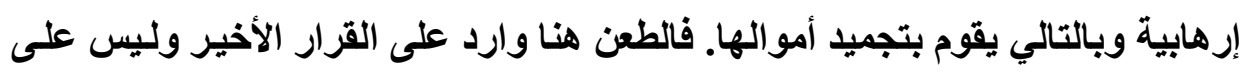
لانحة المجلس. وعادة يقتضي الحق في دعوى عادلة أن يتم إخطار الشخص المعني بالإجراء

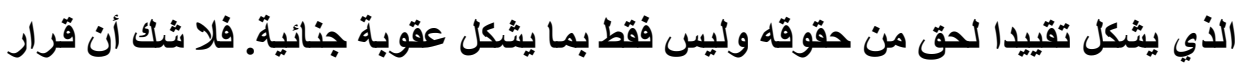

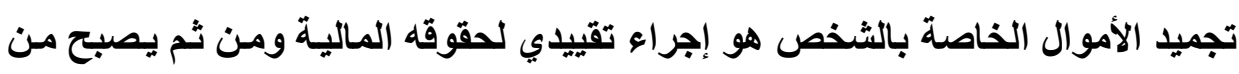

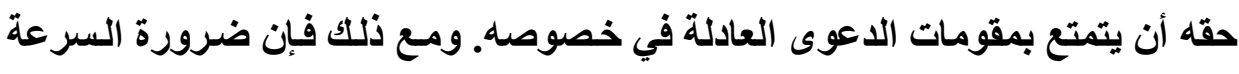

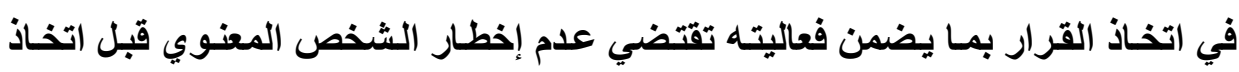

(1) Yusuf and Al Barakaat International Foundation $v$ Council and Commission [2005] 
القرار بما يعني أنه يمكن وضعه على قائمة الإرهاب وتجميد أموالـه في قرار واحد ولا يكون إخطاره بذلك إلآ بعد وضع القرار موضع التنفيذ. وفي وقت لاحق يـتم الإخطار بذلك مع تمكينه من الحق في الطعن أمسام محكمة توفر لله ضمانة الدعوى العادلة في الحدود السابق بيانها. التأكيسد على هبـدأ قـضائية التحديـد للتنظيم الإرهـابي (القـانون المصري نهوذجاً: عالج القانون المصري في شـأن تنظيم قوائم الكيانـات الإرهابية والإرهـابيين

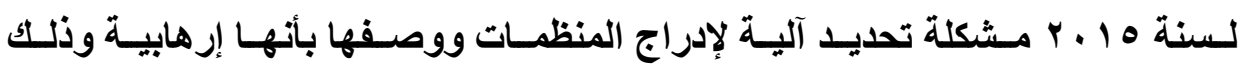

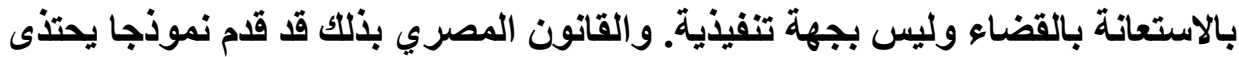
به يحقق التوازن بين مصلحة المجتمع في حظر التظيمات الإرهابية وضمان مقتضيات الدعوى العادلة التي يتعين احترامها حتى مع من يتهم بارتكاب أفعال الإرهاب أو من

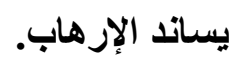

وتتلذص الضمانات التي احتواها القانون المصري في النقاط التالية: أولا- الحق في محكمة، وذلك بأن قرر القانون المصري اختصاص محكمة استنناف القاهرة (دائرة جنايات) بالنظر في إدراج تنظيم معين على قائمسة الإرهاب. كما

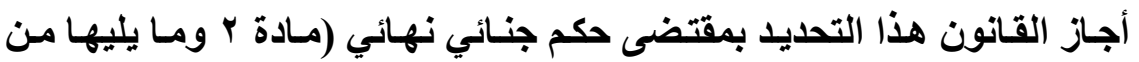

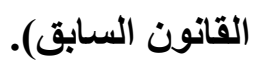

ثانيا- يتم تحديد دائرة الجنايات بمكمة استئناف القاهرة من جانب الجمعية العمومية

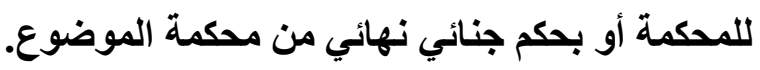

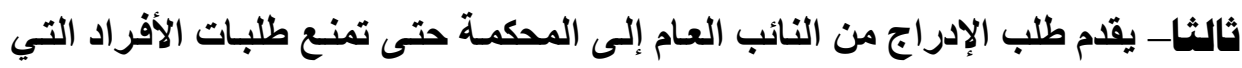
أحيانا تكون مدفوعة باعتبارات شخصية. وفي حالة المنظمـات الأجنبية يكون 
تقديم الطلب من النائب العـام وذلكك بعد تقديم طلب إليهه من وزارة الخارجية بالتنسيق مع وزارة العدل أو من جهات الدولة الأمنية إلى النائب العام (مـادة ب من القانون السابق). رابعا - يصدر القرار الصادر بإدراج التنظيم على قائمة الإرهاب مسببا (مادة ؟r). خامسا- يسري القرار الصادر بإدراج التنظيم لمدة ثنلاث سنوات حتى صدور الحكم البات باعتبار التظيم إرهابيا. وإذا لم يصبح الحكم باتا في تلك المهلة "تعين على النيابة العامة إعادة العرض على الدائرة المشار إليها للنظر في مد الإدراج

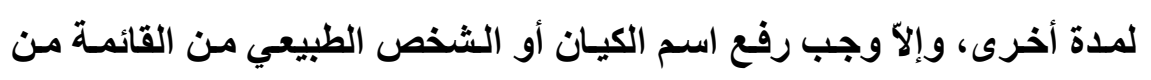
تاريخ انقضاء تلك المدة"('). سادسا- يجوز رفع التظيم من قائمة الإرهاب بنـاء على طلب النائب العام بـأن يطلب

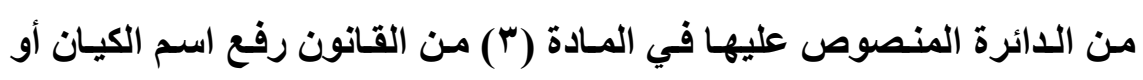
الثخص الطبيعي المدرج على أي من القائمتين". سابعا- يجوز الطعن في القرار الصادر بإدراج التنظيم على قائمة الإرهـاب وذلك أمسام الدائرة الجنائية بمحكمة النقض التي تحددها الجمعية العمومية للمحكة سنويا،

(1) في ذلك تنص المادة الثالثة من القانون السابق على أنه "تختص دائرة أو أكثر من دوائر الجنايات

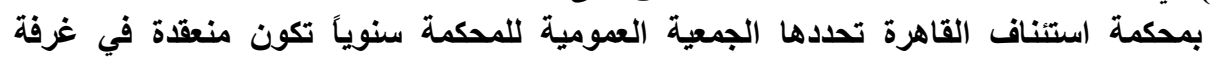

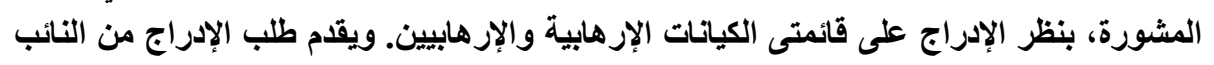

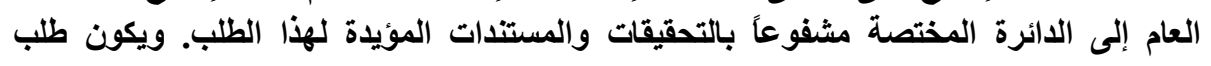

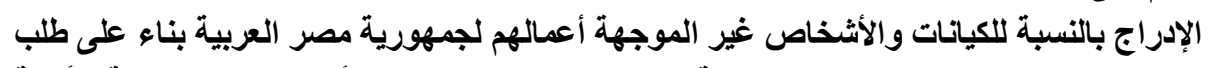

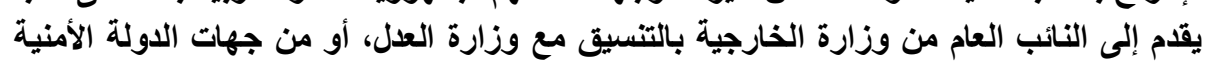

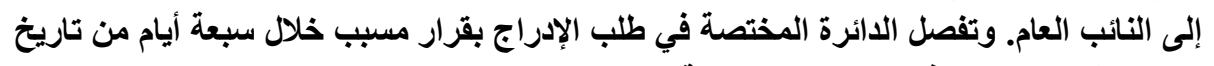
تقديم الطلب لها مستوفيا المستتدات اللازمة" المهل 
خلال ستين يوما وفقا للإجراعات المعتادة (مادة ؟) من جانب صساحب الشأن أو

النيابة العامة، وهو ما يؤكد ضمانة الحق في محكمة(').

\section{مشكلة تهديد المنظمات الإرهابية والسرعة الواجبة عند تهميد الأههوال:}

من مظاهر التخلي عن الضمانات القانونية عند محاربة التظظيمـات الإرهابيـة مـا تقوم به الأمم المتحدة من وضع قائمـة للمنظمـات الإرهابية وقيامهـا بتجميد أموال تلكك المنظمـات دون إخطسار سـابق اعتمــادا على عنصر المفاجـأة حتى تحقق فعاليـة تلكـ التدابير. غير أن تلك الفعالية تتعارض مع الضمانات القانونية المقررة مثل صدور قرار إدراج منظمة معينة في قائمة الإرهاب بناء على مواجهة المسئولين عن تلك المنظمـة بالأدلـة التـي تفيــ تورطهـا في الإرهـاب والسماح لهـا بالـدفاع عن نفسـها. كمـا أن الضمانات القانونية التقليدية تسمح لهم بطلب مسح تلك المنظمـات من قائمـة الإرهـاب، بالإضافة إلى حق هؤلاء المسئولين في الطعن في تلك القرارات. كل تلك الضمانات لا

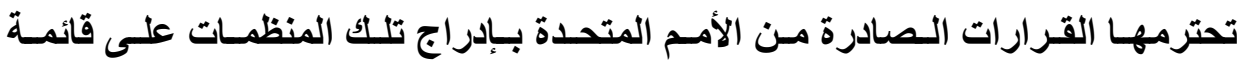

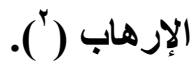

(1) مادة ؛ - يكون الإدراج على أي من القائمتين لمدة لا تجاوز ثُلاث سنوات. فإذاذا انقضت مدة الإدراج

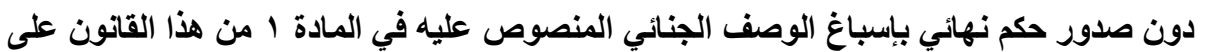

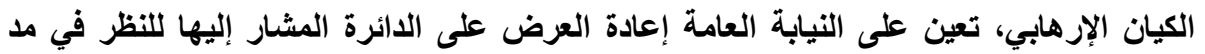

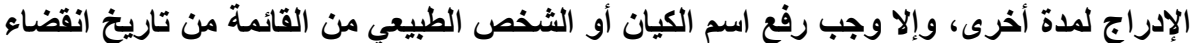

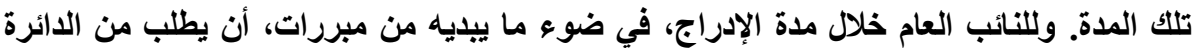

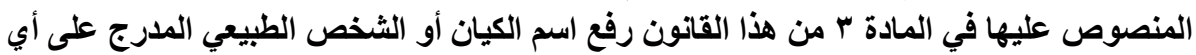
من القائمتين.

(2) A Bianchi, 'Assessing the Effectiveness of the UN Security Council's Anti-terrorism Measures: The Quest for Legitimacy and Cohesion' (2006) 17 European Journal of International Law 881, 903-10..

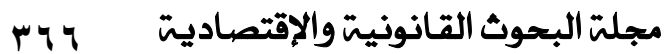


يترتب على ذلك الإخلال بحق أعضاء تلك المنظمـة في الملكية حيث يتم تجميد

أموالهم ومنعهم من التعامل مع الجهات المختلفة؛ فيصبح ممنوعا عليهم البيع والثراء ويصبح ممنوعا عليهم حتى ركوب الطائرات والتنقل عبر الدول. تلك الدول يطلب منها القبض علـيهم باعتبـار هم منتمـين إلـى منظمـات إرهابيـة. ومسن يخـالف هـذا الحظر المفروض يتعرض هو نفسه للجزاعات سواء تعلق الأمر بأفراد أو شركات أو دول(') غير أن محكمة العدل الأوربية أكدت ـ في قضية Kadi سنة م . . . ـعلى حق من يتم إدراجه على قائمة الإرهاب في سماعه وحقه في الطعن في قرار إدراجه على قائمة الإرهاب ولو تعلق الأمر بمن سبق إدراجهم على قائمة الإرهـاب عن طريق لجنـة الجزاءات التابعة للأمم المتحدة. ذلك أن إدراجهم على قائمة الإرهـاب الأوربية يجب أن يكون مع احترام مبادئ الدعوى العادلة)(r).

(1) 1 Cameron, 'European Union Anti-Terrorist Blacklisting' (2003) 3 Human Rights Law Review 225

(2) Joined Cases C-402/05 P and C-415/05 P Kadi and Al Barakaat International Foundation v Council (ECJ 3 September 2008) 283-284. 
أ.د/ شيماء عبد الغنى محمد عطا الله

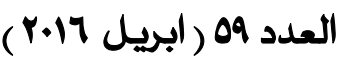

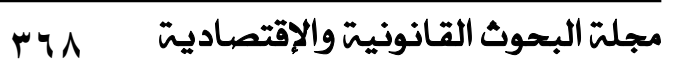




\section{الفصل الثاني \\ النتائج القانونية المترتبة على اعتبار \\ التنظيم إرهابياً}

تتعدد النتائج التي تترتب على اعتبار منظمة مـا إرهابية إلى نتائج موضوعية

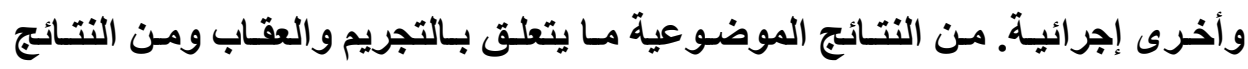

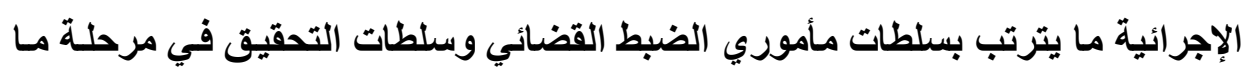

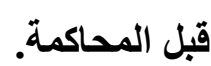

\section{المبحث الأول \\ ظهور صور جديدة هن الجرائم ترتبط بنشأة التنظيم الاول \\ وهمارسة نشاطه}

تنبه المشرع في العديد من البلاد على اختلاف توجهاتها إلى أن القواعد العامـة

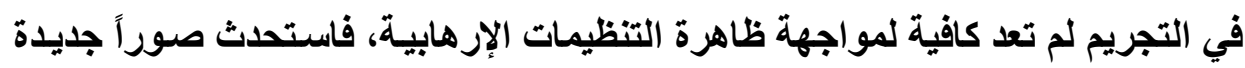

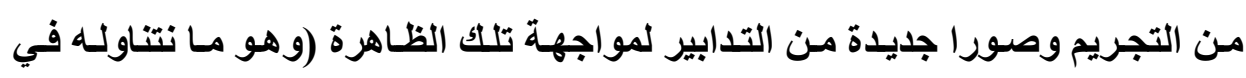
المطلب الأول). وفي تصور ها لتلك الصورة من التجريم و العقاب استلهمت القوانين فلسفة جديدة تقوم على مبادئ غير تقليدية سوف نتناولها في المطلب الثاني؛ ولمورئ 


\section{المطاب الأول \\ استحداث صور جديدة للتجريم ترتبط \\ بالتنظيمات الإرهابية}

يترتب على صدور قرار بوصف المنظمـة بأنها إرهابية ظهور مجموعة من الجرائم التي لم تكن موجودة وهي متعلقة بنشأة واستمرار التنظيم. من أهم تلك الجرائم ما يلي: - تجريم تأسيس منظمة إرهابية - تجريم العضوية في منظمة إرهابية - تجريم تجنيد أعضاء لمنظمة إرهابية

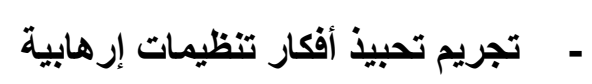
- تجريم تدريب وتلقي التدريب بغرض الإرهاب - تجريم تقديم الدعم أو طلب الدعم لمنظمة إرهابية(').

(1) تأثراً بالاتجاه الحديث في النص على صور جديدة من الجرائم التي ترتبط بظهور التنظيمات

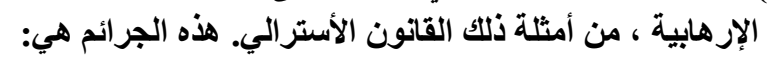

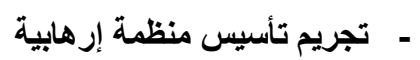

Criminal Code, ss 102.2 )and (2) respectively - - تجريم عضوية منظمة إرهابية - - تجريم تجنيد أعضاء في المنظمة إنمابية الإرهابية

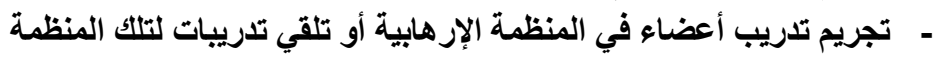

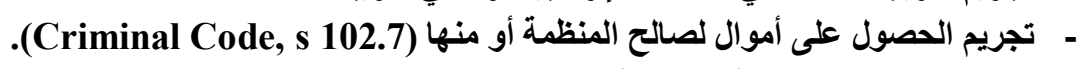
- تجريم تقديم دعم للمنظمة الإرهابية (Criminal Code, s 102.7).

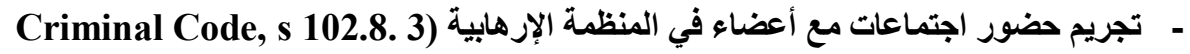

PV. مجلتّ البحوث القانونيت والإقتصاديت 


\section{فائدة استمداث الجرائم المتعلقة بالتنظيم الإرهابي:}

يسمح وجود هذا الجرائم المستحدثة المتعلقة بالتنظيم الإرهابي بتوحيد التجريم بين الدول المختلفة تسهيلا لعملية تسليم المجرمين، بالإضافة إلى حسن تطبيق القانون من حيث المكان. وقد سمح ذلك بتطبيق القانون الفرنسي على أحد رعايـا يوغسلافيا الذي ارتكب جريمة في هولندا بعد الإعداد لها مع أحد الرعايا الفرنسيين في فرنسا. فقد رأت محكمة النقض الفرنسية أن الأفعال تشكل وحدة واحدة تثمثل في الاشترالك في اتفاق إجرامي association de malfaiteurs التي وقعت في الإقليم الفرنسي('). غير أنـه في حالـة ارتكاب جريمـة من هذا التنظيم كجريمـة القتل مثثلا، فِإن الجريمـة الواقعـة تختلـف عـن مجـرد الاشـتراك فـي اتفــاق جنـائي وفـي حالــة الاثــتراك فيهـا بـالتحريض أو الاتفـاق أو المسـاعدة ينعقد الاختصاص لقـانون البلـد التي وقعت فيها الجريمـة الأصـلية كالقتـل. ولا يكـون القـانون الفرنسـي مختصـا - بحسب الأصـل -

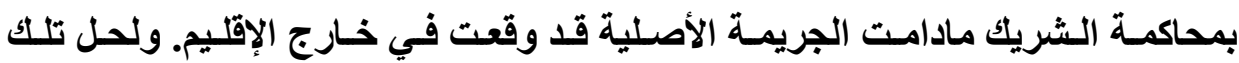
المشكلة يمكن النص في القوانين الداخلية على الاختصاص العالمي للعقاب على بعض الجرائم الخطيرة والتي لها أبعاد عابرة للحدود بين الدول. من ذلك أن التحريض على ارتكاب جرائم الإرهاب سواء في داخل البلاد أو خارجها أصبح جريمـة مستقلة وكذلك التحريض على الانضمام إلى تنظيمات إرهابية، ومن ثم فبان الاختصاص ينعقد لقانون البلد التي حلث فيها ذلك التحريض ولو وقعت الجريمـة في خارج البلاد. غير أن هذا الحل يحل جزء من المشكلة حيث تبقى الجريمة الإرهابية التي وقعت في الخـارج بمنـأى عن اختصاص البلا التي حدث فيها التحريض. لذا كان تقرير الاختصاص العالمي أفضل

(1) Crim. 23 avr. 1981, Bull. crim., $\mathrm{n}^{\circ}$ 116, cette Revue, 1982, p. 609, obs. Vitu. 
للاختصاص بالتحريض وبالجريمة الإرهابية أيضا التي وقعت في الخارج. وقد نص

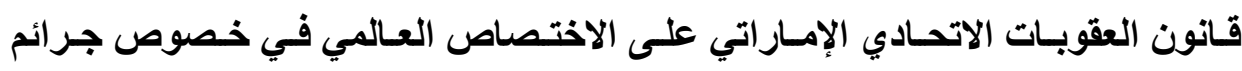

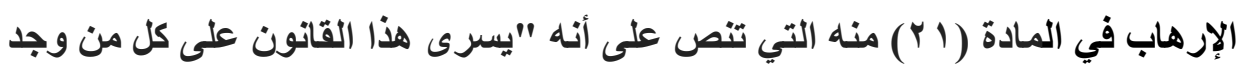
في الاولة بعد أن ارتكب في الخارج بوصفه فاعلا أو شريكا جريمة تخريب أو أو تعطيل

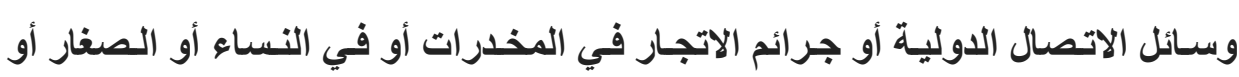

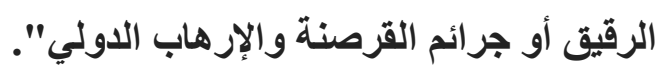

كمـا أن قـانون مكافحـة الإرهـاب في بريطانيـا لسنة .... ب قرر الاختصاص

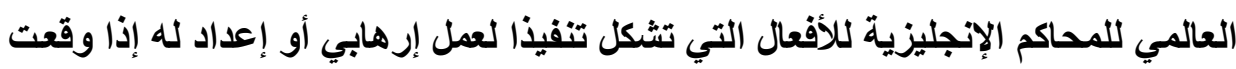
في خارج البلاد مادام أن هذا الفعل يقع تحت طائلة التجريم وفقا للقانون الإنجليزي. أولا - تجريم العضوية في التنظيمات الإرهابية: من صور التجريم الحديثة التي ارتبط ظهورهـا بظهور التنظيمـات الإرهابيـة تجريم العضوية في تلك التنظيمات، على ما سيلي بيانه؛

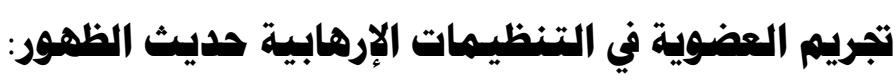

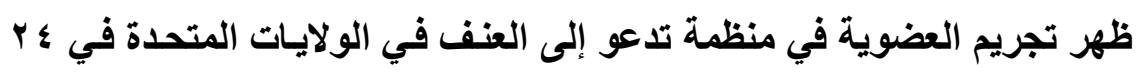

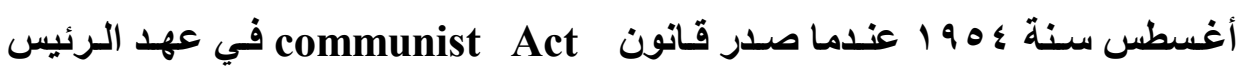
ايزنهاور يجرم تأسيس أو الانتماء لحزب شيوعي(') باعتباره حزبا يدعو إلى العنف

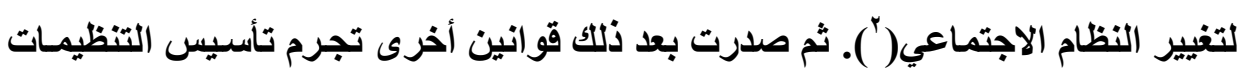
Antiterrorism and Effective Death Penalty Act الإرهابية منها قانون

(1) 68 Stat. 775, 50 U.S.C 841

(2) https://en.wikipedia.org/wiki/communist_Control

PVY مجلت البحوث القانونيت والإقتصاديت 
1996 والذي يمنح وزير الخارجية سلطة تعيين المنظمـات الإرهابية وقد أدرج في

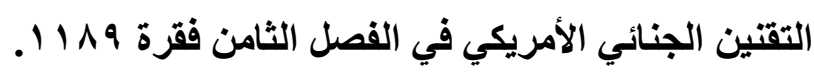

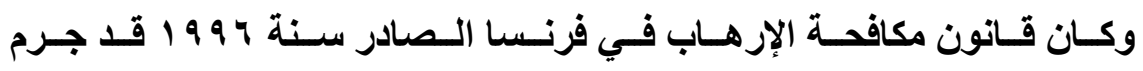

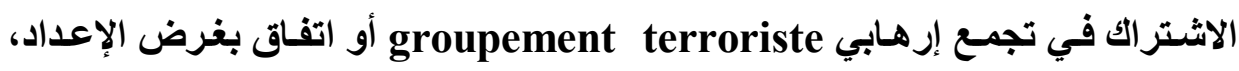
بفعل مادي أو أكثر، لعمل إرهابي مما هو مشار إليه في هذا القانون.

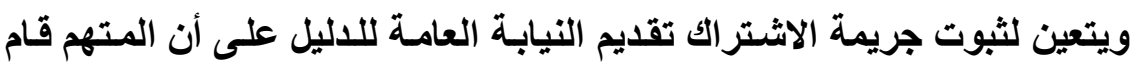

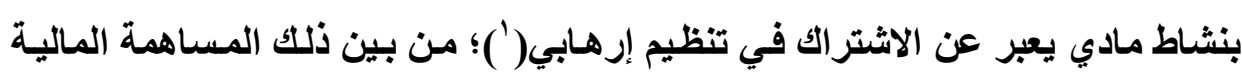

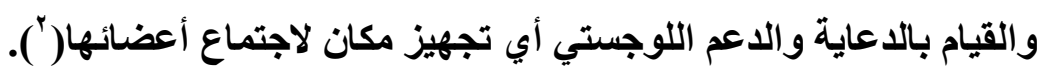

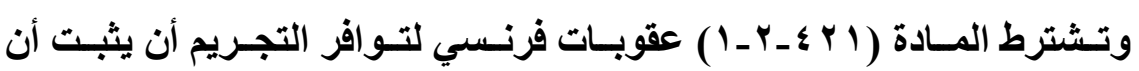
التنظيم الذي يشترك فيه المتهم يعد لارتكاب جرائم إرهابية، غير أن هذا الشرط خفف منه المشرع والقضاء على الوجه التالي:

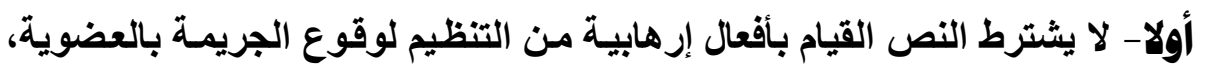

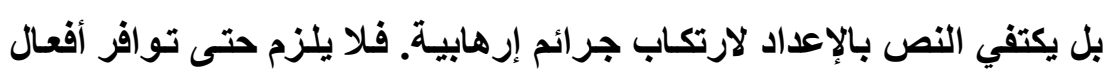

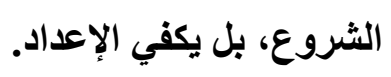

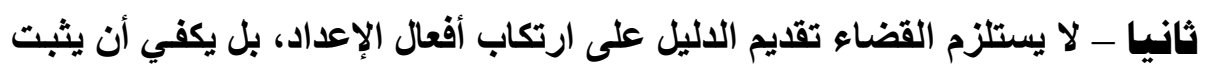

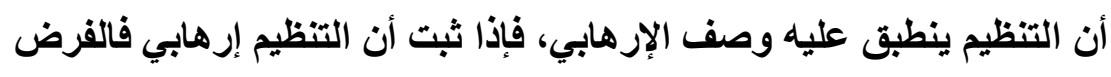

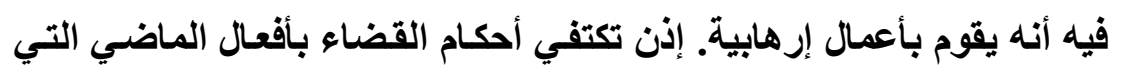

(1) JulieAlix, Réprimer la participation au terrorisme, RSC 2014 p. 849

(2) Crim., 21 mai 2014, Association CCK Ahmet Kaya, n ${ }^{\circ}$ 13-83758, publié au Bulletin. Sur cetarrêt, v. déjà $P$. de Combles de Nayves, Sauf en matière terroriste, AJ pénal 2014. 528 ; M. Véron, Dr. pénal 2014 n ${ }^{\circ}$ 7-8 comm. 106. 
من خلالها ثبت أن التظيم إرهابي، دون النظر إلى أفعال المستقبل على خلاف

$$
\text { ما يال عليه ظاهر النص('). }
$$

ثالثا - لا تشترط أحكام القضاء أن تكون الجريمـة التي يُعد لهـا معينة على سبيل

$$
\text { التحديل، وإنما يكفي أن تكون أفعال إرهاب بوجه عام. }
$$

\section{مكافمة تكوين المنظمات الإرهابية والعضوية فيها على المستوى الدولي:}

تجريم تأسيس وكذلك الانتماء إلى منظمات إرهابية، وبالتـالي اتخـاذ تدابير ضد

تلك التظظيمات وأفرادها هما من الموضوعات الحديثة، وهو بالتأكيد من أحدث الجرائم الإرهابية بوجه عام. وإذا تحدثنا عن ظهور الجرائم الإرهابية على المستوى العالمي،

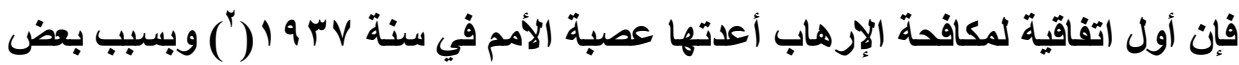
الأفعال التي وقعت ضد الطائرات ومنهـا خطف تلك الطائر ات، كانت اتفاقيـات طوكيو

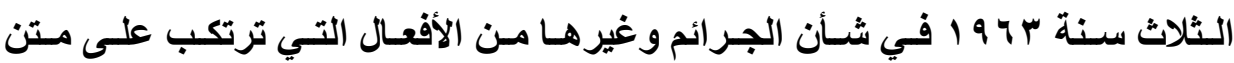
الطائرات، ثم اتفاقية مونريـال سنة ا9V I للعقاب على الأفعال غير المشروعة التي تهدد سلامة الطيران المدني. وتزايـ الاهتمـام بمكافحة الإرهاب والتظيمـات الإرهابية بشكل كبير منذ حادث لوكربي سنة 919 19 ـوفي التسعينات تأكد الاهتمـام بالتظيمـات الإرهابيـة عندما أعدت الجمعيـة العامـة للأمسم المتحدة اتفاقيـة ضــ الإرهـاب باستخدام القنابـل وتمويـل الإرهـاب سـنة 999 1 ـ وصـدر لمجلس الأمسن قرارات بجز اعات ضــ

(1) Crim., 21 mai 2014, Association CCK Ahmet Kaya, n 13-83758, publié au Bulletin. Sur cetarrêt, v. déjà $P$. de Combles de Nayves, Sauf en matière terroriste, AJ pénal 2014. 528 ; M. Véron, Dr. pénal 2014 n ${ }^{\circ}$ 7-8 comm. 106

(2) ILIAS BANTEKAS, SUSAN NASH, \& MARK MACKAREL, INTERNATIONAL CRIMINAL LAw 229 (2001). 
الإرهـاب والتنظيمـات الإرهابيـة بفرض جزاعات على طالبـان بسبب توفير هم المسأوى لزعيم تنظيم القاعدة (أسامة بن لادن)('). و إدراكا من المجتمع الدولي لأهمية مكافحة تمويل المنظمات الإرهابية كانت اتفاقية مكافحة هذا التمويل سنة 999 و 1. الأسلوب المتبع في تجريم العضوية في التنظيم الإجراهي بوجه عام: يمكن تجريم التنظيم الإجرامي من خلال اللجوء إلى أسلوب من اثنين: أن نجعل ارتكاب الفعل من عصبة ظرفا مشدداً، والأسلوب الثاني هو إدخـال تجريم جديد للعقاب على مجرد الاثتراك في تنظيم إجرامي. ومن الواضع أن الأسلوب الثاني أفضل ذلك أنـه يعاقب على مجرد الاشتراك في التنظيم. كمـا أنها يوحد التجريم بين القوانين في البلاد المختلفة، الأمر الأي من شأنه أن يسهل عمليه تسليم المجرمين. ويعد تجريم الاشتراك في تنظيم إجرامي من صور التجريم الحديثة نسبيا، ومـع ذلك فقد عرفت القوانين المختلفة تجريم الاتفاق الجنائي. هذا النوع من التجريم قضت

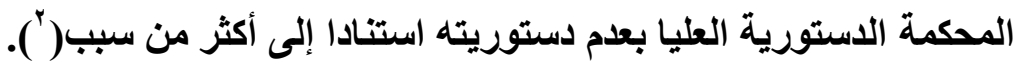
من أهم أوجه العوار في صياغة المادة (^ ؛ ) من قانون العقوبات التالي: ـ عدم احترام مبدأ الشرعية الجنائية التي تستلزم وضوح النص حيث ورد التجريم على الاتفاق على جناية أو جنحة دون تحديد. فتقول المحكمة "قد يكون محل الاتفاق عدة جنايات، أو عدة جنح، أو مجموعة جرائم مختلطة من النوعين معا، كمـا قد لا يرد الاتفاق إلا على جناية أو جنحة واحدة، ولم يستثزم النص أن تكون الجريمـة أو

(1) (http://heinonline.org, CURRENT DEVELOPMENTS, THE INTERNATIONAL LAW OF TERRORIST FINANCING, 97 Am. J. Int'l L. 3152003

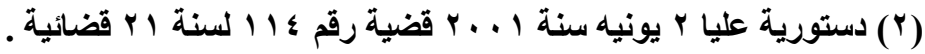

rvo مجلت البحوث القانونيت والإقتصاديت 
الجرائم المتفق على ارتكابها على درجة من الجسامة، بل قد يكون محل الاتفـق

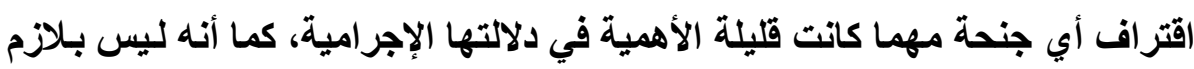
أن تتعين الجناية أو الجنحة محل الاتفـق كمـا لو تم الاتفاق على استعمال العنف ـ بأي درجة ـ لتحقيق غاية الاتفاق، سواء كاتت هذه الغاية في ذاتها مشروعة أو غير الفي مشروعة، ومن ثم فبان نطلق التجريم جـاء واسعا فضفاضا لا تقتضيه ضـرورة

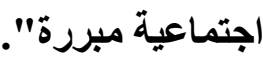
- لا يحقق التجريم الغرض منه وهو الردع وبالتالي فإنها يخالف مبدأ الضرورة. في ذلكت تقول المحكمة "الفقرة الرابعة مـن المـادة ه ؛ تقرر توقيع العقوبـة المقررة لارتكاب الجناية أو الجنحة محل الاتفاق على مجرد الاتفاق على اقتر افها حتى ولو لم

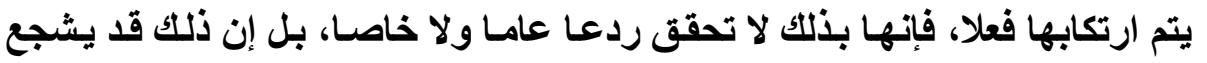
المتفقين على ارتكاب الجريمـة محل الاتفـق طالمـا أن مجرد الاتفـاق على اقترافها

$$
\text { سيؤدي إلى معاقبتهم بذات عقوبة ارتكابها". }
$$

- عدم احترام مبدأ الضرورة أيضا حيث إن التجريم يعاقب على الأعمال التحضيرية. فـي ذلكـ تقـول المحكمـة "وكـان مجـرد العزم علـى ارتكـاب الجريمـة أو الأعمـال

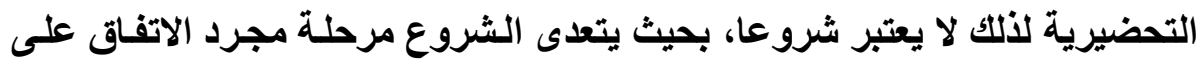

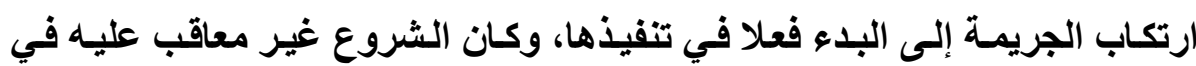

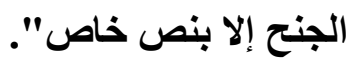
ـ عدم احترام مبدأ التناسب في التجريم. فتقول المحكمة "تنص ذات الفقرة على أن عقوبة الاتفاق الجنائي على ارتكاب الجنح هي الحبس أي وضع المحكوم عليه في

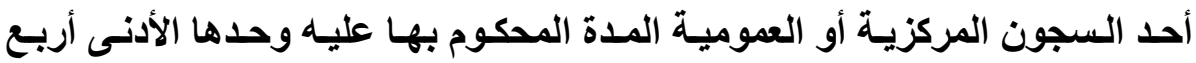

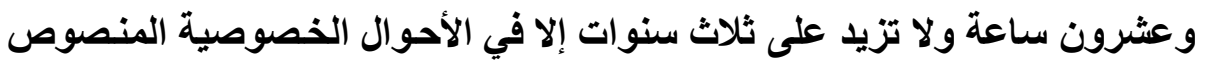


عليها قانونا، بينما هناك جنح متعددة حدد المشرع العقوبـة فيها بـالحبس مدة تقل عن ثُلاث سنوات؛ وهو مـا يكشف عن عدم تناسب العقوبـات الواردة في الفقرة الثانية من النص المطعون فيه مع الفعل المؤثث، ـ عدم احترام مبدأ التناسب أيضا من حيث إن "محل الاتفاق - قد يكون ارتكاب جناية أو جنــة غير معينـة بـاتها وعندئـــ توقع العقوبـات الواردة في الفقرة الثانيـة مـن المادة وحدها، وهي تصل إلى السجن خمس عشرة سنة أو الحبس ثُلاث سنوات ـ حسب الأحوال - ولا شك أنها عقوبات مفرطة في قسوتها تكثف عن مبالغة المشرع في العقـاب بمـا لا يتناسب والفعل المـؤثم". وتقول المحكمـة أيضـا إن "النص في المادة ^^؛ على تجريم مجرد اتحاد إرادة شخصين أو أكثر على ارتكـاب أي جنايـة أو جنحة أو على الأعمال المجهزة أو المسهلة لارتكابها، وتحديد العقوبـة على النحو السالف بيانه بالعقوبة المقررة لارتكاب الجناية أو الجنحة محل الاتفـاق، فإنها يكون منتهجا نهجا يتنافر مع سياسة العقاب على الشروع، ومناقضا ـ بالتالي ـ للأسس

$$
\text { الاستورية للتجريم". }
$$

غير أن القوانين المقارنة هي أيضا قد تضمنت تجريمـا ممـاثلا للاتفـق الجنائي. فأصبح التجريم في مجـال التنظيمـات الإرهابيـة يقوم على فلسفة تستهـف الاتفـاق الجنـائي دون انتظـار وقـوع جريمـة معيــة أو حتـى شـروع فيهـا. فأصسبحت الأعمـال التحضيرية تكفي للتجريم والعقاب. بل أصبح مجرد الاتفاق يكفي لهذا التجريم وذلك العقاب. ومؤدى ذلك أن هنالك تطورا في الفكر القانوني في التشريعات المختلفة. ومؤدى ذلك أيضا أن اعثراض المحكمة الدستورية على المادة (^ ؛ ) بخصوص الاتفاق الجنائي والمستند إلى أن التجريم يخـالف مبادئ الشروع في الجريمـة وأن التجريم يستهدف 
مجرد تلاقي الإرادات ولا يعبر عن سـلوك إجرامسي أصبح غير ذي محل في فلسفة التجريم والعقاب في مجال جرائم التظيمات الإرهابية. فقد أصبح تجريم الاتفاقات الإرهابية في صورة إنشاء أو العضوية في تنظيم إرهابي أو حتى التخطيط أو الاعوة إليه أو تقديم العون والتمويل أو الترويج أو التحبيذ مستندة إلى مبلأ الضرورة أي ضرورة مكافحة هذا اللون من النشاط الإرهابي الخطير. وقد أدركت تثريعات مقارنة خطورة تكوين عصابات إجرامية قبل أن يستشري خطر التنظيمات الإرهابية مثل التشريع الفرنسي عندما جرم الاشتراك في عصبة إجرامية

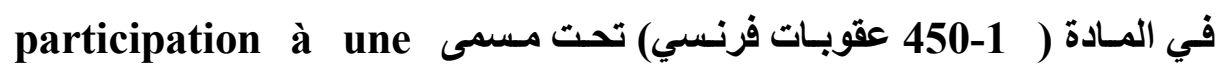
association de malfaiteurs التجريم هو الأخر غير كاف وأدخلت تجريما يعاقب على الاشتراك حتى يتم التوحيد بين القوانين في المفاهيم الأمر الذي يسهل تسليم المجرمين بين الدول المختلفة، كما يحترم مبدأ الثرعية حيث يتم تحديد الجرائم التي يكون الهدف من التظيم الإجرامي ارتكابها. وواضح أن هذا النوع من التجريم مفيد في القانون المصري وخاصـة بعد أن تم إلغاء التجريم الخاص بالاتفاق الجنائي. وقد روعي في هذا النوع من التجريم أن يتم احترام مبدأ الشرعية في الشث بـ الخاص بوجود الركن المادي بحيث يتعين أن يظهر نشاط للمتهم في الانضمام للتنظيم

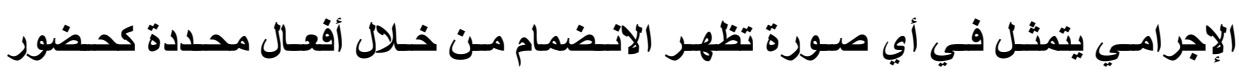
اجتماعات أو دفع أموال أو إعطاء معلومات أو أسلحة. 
ومسن ناحية أخرى تمثيل احترام مبدأ الشرعية في تحديد جرائم معينة يكون

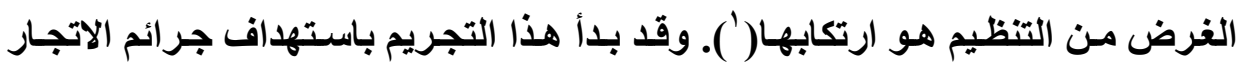

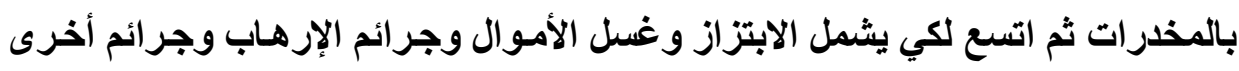
جسيمة تم تحديدها في التجريم.

وقد أدخل المشرع الفرنسي بمقتضى القـانون الصادر في بـ إ نـوفمبر سـنة

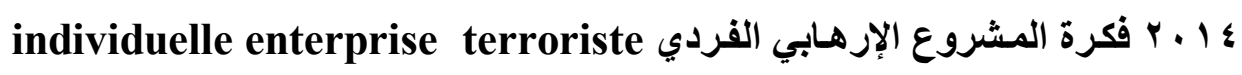

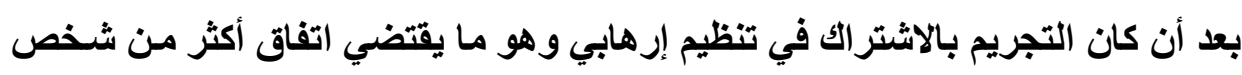

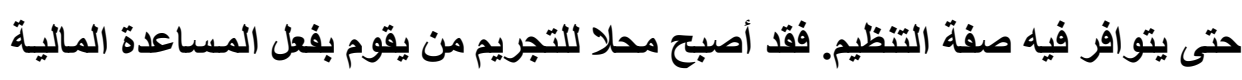

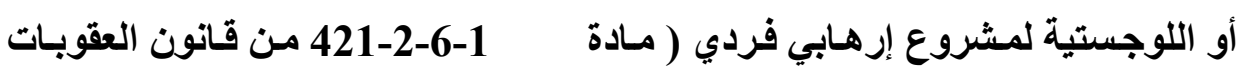

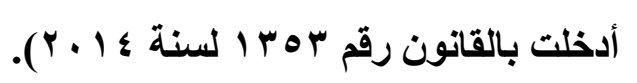

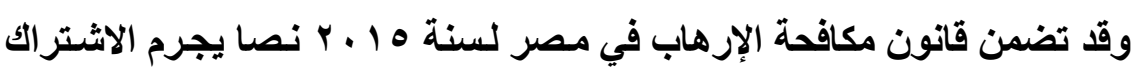

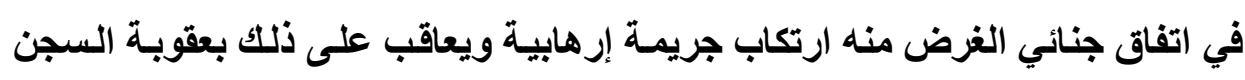

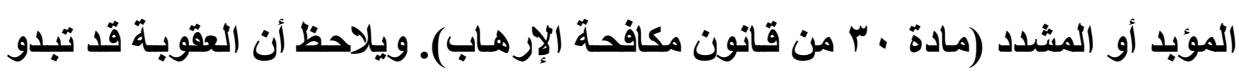

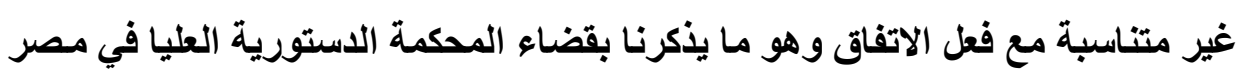

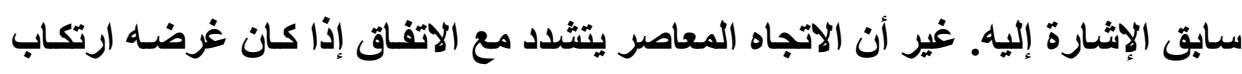

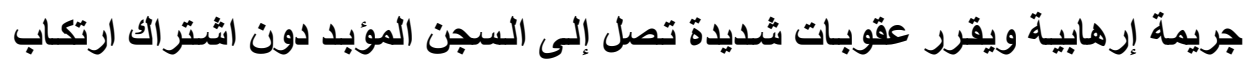
الجريمة الإرهابية محل الاتفاق. وبالإضـافة إلى الجانب الموضسوعي في التجريم، فقد كانت هنـاك انعكاسـات إجرائية لهذا التجريم تمثلت في جواز التحريض الصوري من رجل الشرطة أو التسلل (1) د. غنام محمد غنام، الوجيز في شرح قانون العقوبات ـ القسم العام ، مطبوعات جامعة

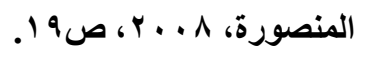

rvq مجلتّ البحوث القانونيتَ والإقتصاديت 
بين المجرمين بقصد كشف تلك الجرائم وجواز الحكم بالإعفـاء من العقاب لمن يقوم بالتبليغ من أعضاء التنظيم عن الجرائم المستقبلة. تجريم تكوين تنظيمات الإرهابية والعضوية فيها في القانون الألماني:

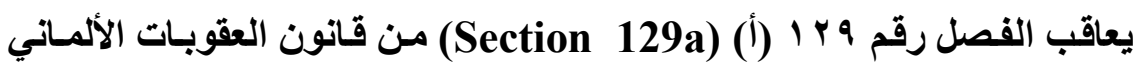
تحت عنوان إنثاء منظمات إرهابية Forming) terrorist organizations) على عدة أفعال تتعلق بالتنظيمات الإرهابية، منها: إنشاء منظمة يكون هدفها أو أنشطتها متجهة إلى ارتكاب أفعال إرهابيـة(').

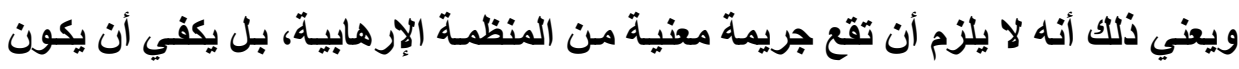

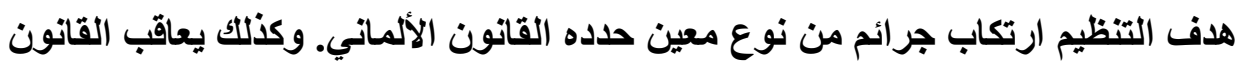
الألماني في الفصل (9 ب 1 ) منه على العضوية في التظيم الإرهابي.

كما يعاقب بذات العقوبة كل من اشترك في نشاط تلكك المنظمات كعضو فيها. العقوبة المقررة هي الحبس من سنة إلى عشر سنوات. وقد أحسن المشرع الألماني

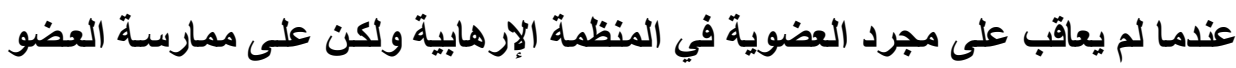
نشاط في تلك المنظمة.

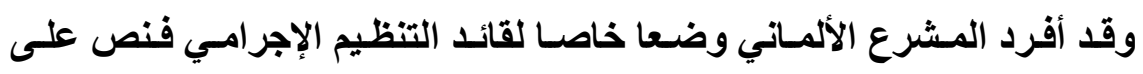
عقوبة أثد تواجه خطورتها الإجرامية بحيث يشدد العقاب عليه عن العضو المشارك بحيث لا تقل عن ثلاث سنوات. كما واجه المشرع الألماني وضع هؤلاء الذين يدعمون التنظيمات الإرهابية فقد

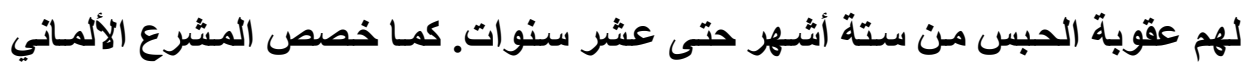
(1) aims or activities are directed at the commission of.....

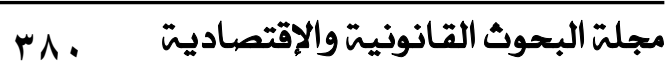


نصا خاصا لتجريم من يقوم بتجنيا مساعدين supporters لتبك المنظمات ويعاقب من يفعل ذلك بالحبس من ستة أشهر إلى خمس سنوات. ونعتقد أن المقصود بالمساعدين هنا من يقدم الاعم المادي للمنظمة الإرهابية.

\section{تميز جريمة العضوية في تنظسيم إرهـابي عـن غيرهـا هـن البـرائم المرتبطـة}

\section{بالتنظيم الإرهابي:}

قد تتعدد أوصـاف الفعل الذي يرتكبـه المـتهم بـين وصـف العضوية ووصـف التمويل. للتمييز بين تلك الأوصاف، يميز القضاء بين العضوية في تنظيم إرهابي وبين صور أخرى من العلاقة التي يمكن أن تربط الفرد بالتظيم الإرهابي. فمن ناحية يختلف تمويل التظظيم الإرهابي أو مساعدته أو مد يد العون لـه عن العضوية في أن العضوية

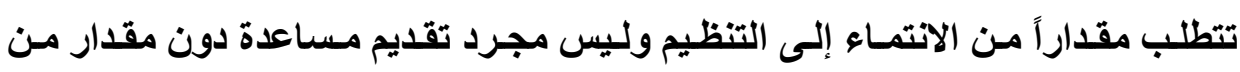
الانخراط في النشاط مـع هذا التنظيم. كمـا أن العضوية تختلف عن مجرد الاتصال

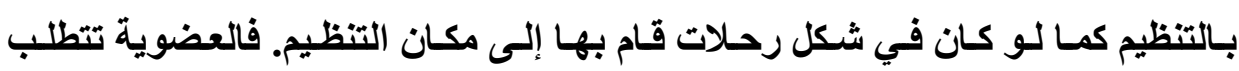
استمراراً وإيجابية في النشاط. ومن ناحية ثالثة تختلف العضوية عن مجرد التعاطف مع التظيم أو تأييا أفعاله أو مبادئه أو استحسانها أو حتى الدعوة له كمـا يحدث أحيانـا على شبكة الانترنت( '). إثبات العضوية في التنظيم الإرهابي:

تستدل المحكمة على أن المتهم عضو في خلية إرهابية من ظروف وملابسات

الدعوى. ويتعين أن يثبت وجود تنظيم أو أكثر من التنظيمات الإرهابية التي ينتمي إليها

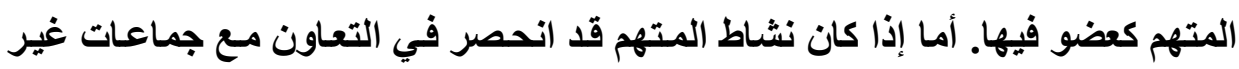
محددة وذلك إرسال مساعدات مالية أو بعض الأسلحة إلى جماعات غير محددة ولكنها

(1) Crim. 21 mai $2014 n^{\circ}$ 13-83.758: Pierre de Combles de Nayves, op.cit.

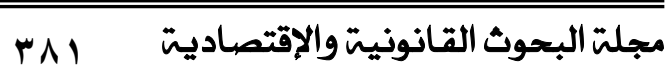


تشترك في اللدفاع عن المسلمين ضـد العدوان عليهم، وإذا لـم يتبين أن المتهم كـان عضوا في تنظيم معين، فإن ذلك لا يثبت بثكل جازم أركان جريمة الانتمـاء إلى التنظيم

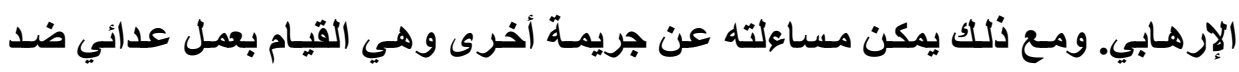
دولة أجنبية دون إذن من الحكومـة. وهي جريمـة مستقلة عن جريمـة الانتماء لتنظيم إرهابي.

تطبيقا لذلك قضت محكمة أمن الدولة في دولة الإمارات العربية المتحدة بوقوع جريمة القيام بعمل عدائي ضد دولـة أجنبية وليس جريمـة الانتمـاء إلى تنظيم إرهـابي

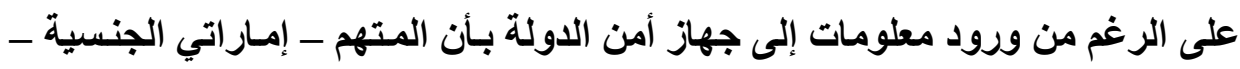
عضو فاعل في خلية إرهابية تنشط على ساحة الدولة ويحوز أسلحة ناريـة، فصدر إذن إنى بالقبض عليه وتفتيشه شخصيا. كمـا أشـارت المعلومـات إلى أنـه مـن العناصر النشطة ضمن خلية شيشانية تنشط على سـاحة الدولة. ... فصدر أمر بالقبض عليه وتفتيش لهن شخصه مسكنه. ونفـاذا لهذه الأوامر تم تقتيش مسكن الأول وعثر على حقيبة جهاز كمبيوتر محمـول وبعض المطبوعـات الخاصـة بتحضير السموم الطبيعيـة والكيماويـة وبتفتيش مسكن الثاني تم ضبط سيارة في جراح المسكن مزودة بأجهزة لاسلكي وبعض

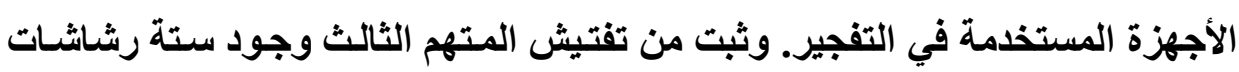

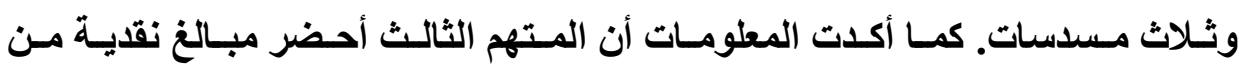
السعودية سلمها إلى المتهم الأول الذي قام بـوره بتوصيلها إلى الجماعة المسلحة العراقية بالاضضـافة إلى مبـالغ أخرى حصل عليها من المتهم الأول كمـا أن هذا الأخير استقبل على صندوقه البريدي رسـالتين تحتوي على أجهزة اتصال لاسـلكية ودوائر

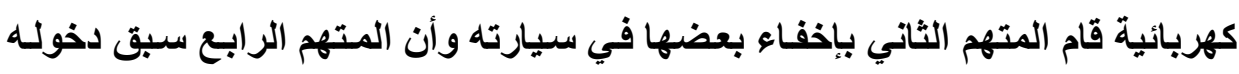

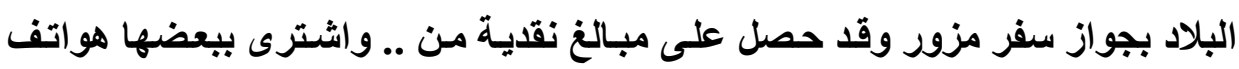
نقاله ومناظير أرسلها مع مبالغ نقدية إلى المقاتلين الشيشان لاستخدامها في في عملياتهر 
القتالية ضد القوات الروسية. وذلك لأن تلك الأدلة لا تفيد الانتماء إلى تنظيم محدد، كما أن ما أنه لم يتوافر لاى المتهمين قصد جنائي للانتماء إلى تنظيم معين ولكنهم قصدوا

إلى الدفاع عن الإسلام ضد العدوان عليه وفقا لما وقر في عقيدتهم ('). همشئولية الشخص المعنوي عن جريمة الانضمام لتنظيم إرهابي: يمكن أن يسأل الشخص المعنوي عن جريمـة الانضمام لتنظيم إرهابي إذا كـان يستخدم في ممارسة أنشطة تجعله على اتصال مستمر مع التنظيم الإرهابي، كما لو كان

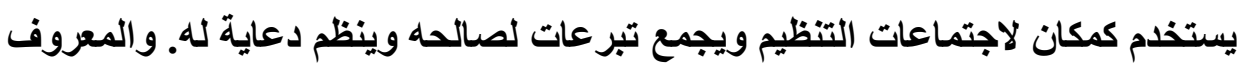

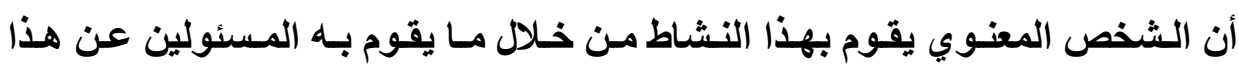

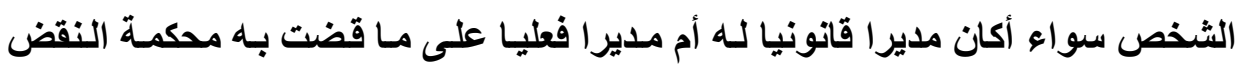
الفرنسية في قضية "حزب العمل الكردستاني"(()). وتتخذ مسئوليته شكل جزاء الحل،

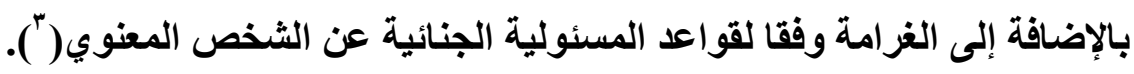

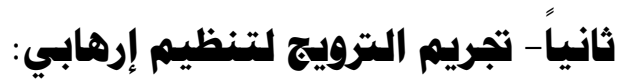
ظهر في الآونة الأخيرة تجريم الترويج لتنظيم إرهابي كصورة حديثة لمحاصرة فكر الجماعات التكفيرية. وبهذه الخطوة ضرب المشرع في التشريعات على اختلاف

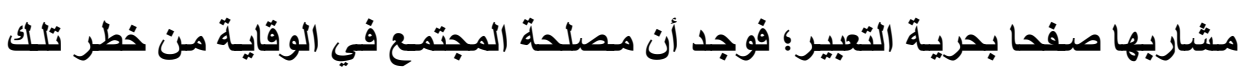
التنظيمـات والحد مـن تعـاظم قوتها تعلو مصلحة الأفراد في التعبير عن آرائهم في استحسان والدعوة إلى فكر معين. لذلك شملت التشريعات المقارنة الاستحسان والمدح والتمجيد والدعوة إلى فكر تلك المنظمـات وكذلك تبرير مواقفها الأيدولوجيـة نوعا من الترويج لتلك المنظمات يستحق التدخل بسلاح التجريم.

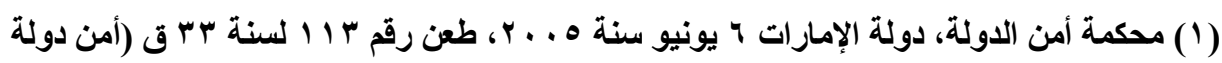

(2) Crim. 21 mai 2014 n 13-83.758: Pierre de Combles, op.cit, p. 528

(3) Crim. 10 avr. 2013, $n^{\circ} 12-82.088$

مجلت البحوث القانونيتّ والإقتصاديت 


\section{تجريم تأييد المنظمهات الإرهابية:}

تطبيقا لألك قضت محكمة أمن الاولة بالإمارات بأن الفعل المنصوص عليه في

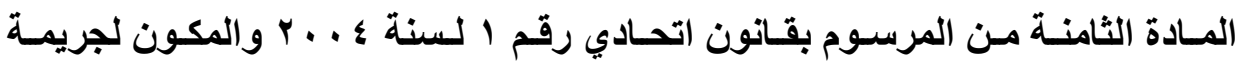
الترويج لأي من الأفعال والأغراض المنصوص عليها في هذا المرسوم بقانون هو صورة من صور تعضيد الأغراض الإرهابية تثمثل في القيام بعدل معين هو الترويج وهو فعل من شأنه تحسين ونشر هذه الأغراض والتقليل من عدم قبولها لاى المجموع، وترى المحكمة أن النص لا يشترط أن يكون القائم بهذا الفعل من أعضاء التظظيمات الإرهابية وعلى ذلك يتصور وقوع الترويج من أحد أفراد التنظيم أو من شخص لا يعد

عضوا فيه(') ).

وقد استدلت المحكمة هذا الفعل من أن المتهم روج بـالقول لتنظيم القاعدة حال

كونـه تنظيمـا إرهابيـا بارتـاء قمـصان تحمـل صـور زعيمـه أسـامه بـن لادن لتحسينه

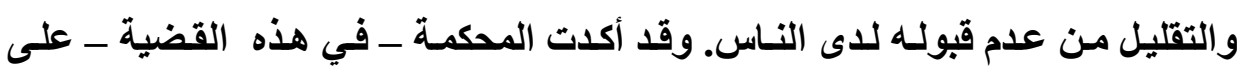
المبادئ القانونية التالية: أولا- أن الفعل المؤثم هو الترويج بتحسين ونشر الأفكار

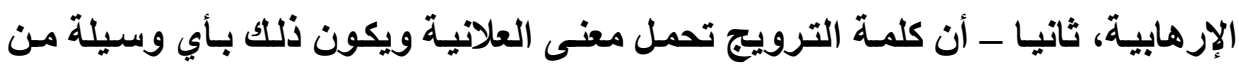
وسائل العلانية كالكتابة أو بأية طريقة أخرى وأن ما قام بـه المتهم من التحدث لبعض لهض الثباب عن أسامة بن لادن زعيم تنظيم القاعدة للتقليل من كراهية العامة له وما قام بـهـ

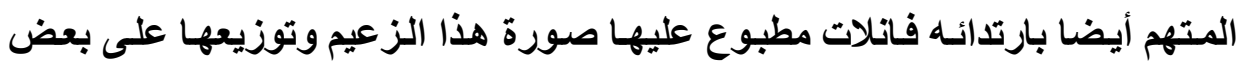
أصدقائه هو ما يتحقق به معنى الترويج في مفهوم مادة العقاب، ثالثا - يتوافر الركن المعنوي في هذه الجريمة بانصراف علم الجاني إلى أنه يستخدم القول أو الفعل أو أية طريقة من طرق الترويج.

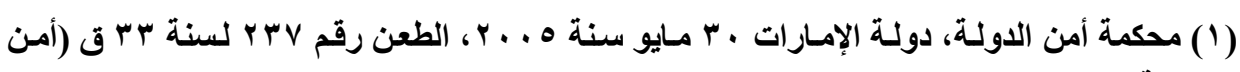


وقد أوضح المشرع الإنجليزي المقصود بتمجيد الأعمال الإرهابية - في المبحث

$$
\text { الخامس من هذا القانون - بقوله: }
$$

التمجيد يتضمن كل أثكال المدح أو الاحتفاء، أياً كان التعبير المستخدم، وأن البيانات والتصريحات تتضمن ليس فقط الكتابة ولكن أيضاً الأصوات والصور.

يعتبر التمجيد غير مشروع إذا كان الرجل العادي يفهم من الأقوال أنها تحث

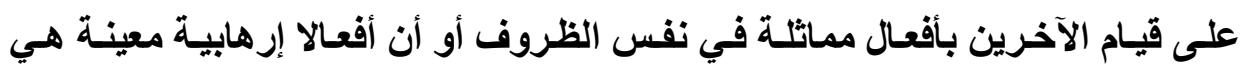
نموذج لما يجب أن يحتذى به.

وقد وسع القانون الإنجليزي لسنة ج . . ب من مجـال تمجيد الأعمال الإرهابية

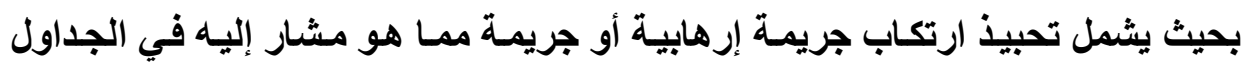
الملحقة بهذا القـانون. هذه الجرائم تشمل بالإضـافة إلى الجرائم التي ينطبق عليهابيا التعريف العام للإرهاب الوارد في قانون سنة . . ب، بل يشمل جرائم أخرى بطبيعتها

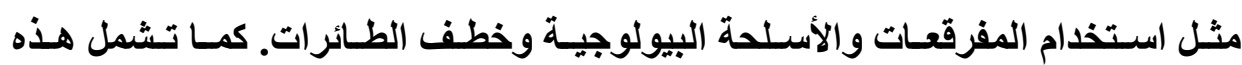
الجداول جرائم أخرى تقليدية مثل السرقة إذا وقعت بباعث إرهابي، فقد يلجأ الإرهابيون

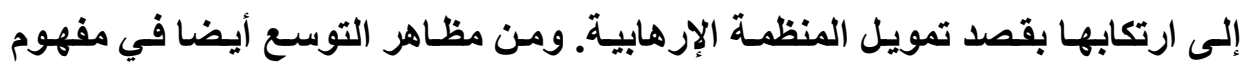

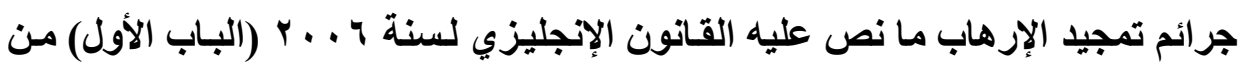

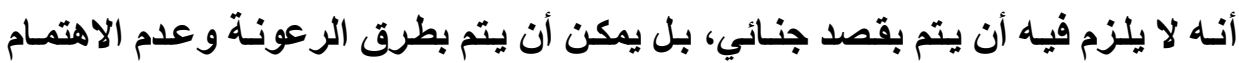
بنشر بيانات أو صور أو أصوت تتضمن هذا التمجيد(').

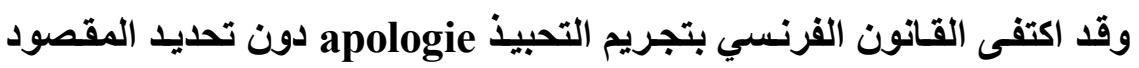
به، تاركـا للمحكمة سلطة استتباط وجود ذلك التأييد أو التحبيذ من سلوك أو أقوال

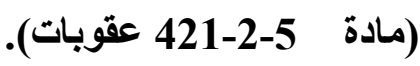




\section{مشكلة تجريم التزويج للتنظيم الإرهابي والحق في التعبير:}

أثيرت مشكلة المساس بـالحق في التعبير عند تجريم الترويج لأفكار تنظيم

إرهابي، حيث يبدو متعارضا مع تلكك الحرية عندما يعبر شخص عن رأيه في استحسان أو تأييد أفكار الجماعـات التي توصف بأنها إرهابية. وقد عُرض الأمـر على المحكمـة الأوربيـة لحقوق الإنسان واعترفت المحكمة بالصعوبات التي تعترض حريـة التعبير بسبب هذا القانون الجديد. ومع ذلك فقد أجازت المحكمة تلك القيود التي ترد على حرية

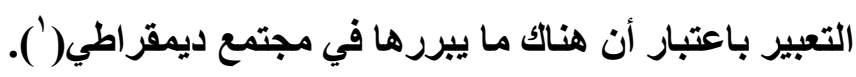

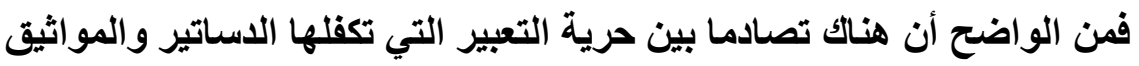
الدولية وبين تجريم تمجيد المنظمـات التي تم وصفها بأنها إرهابية. فكلمـات التأييدا والموافقة على ما قامت بـه منظمـة إرهابية مـن أعمـال تصفها السلطات بأنها إرهابية تشكل نوعا من التعبير ولكنه تعبير أصبحت تعاقب عليه كثير من القوانين بسبب موجة

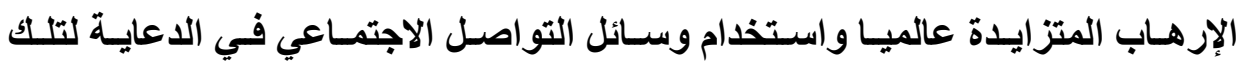
المنظمات والدعوة إلى تجنيا الثباب في صفوفها، الأمر الذي يزيلـ خطورتها ويقوي

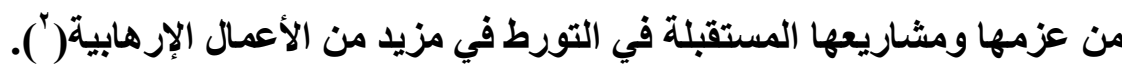

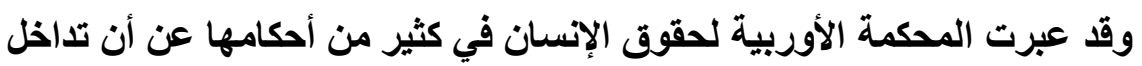

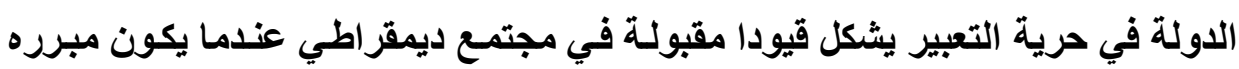

(1) CEDH, 2 oct. 2008, $n^{\circ}$ 36109/03, Leroy c/ France, AJDA 2009. 872, chron. J.-F. Flauss ; RSC 2009. 124, obs. J. Francillon

(2) DARAGH MURRAY,FREEDOM OF EXPRESSION, COUNTER TERRORISM AND THE INTERNET IN LIGHT OF THE UK TERRORIST ACT 2006 AND THE JURISPRUDENCE OF THE EUROPEAN COURT OF HUMAN RIGHTS, 27 Neth. Q. Hum. Rts. 331 2009 (Netherlands Quarterly of Human Rights, Vol. 27/3 (2009), p.330: http://heinonline.org

مجلة البحوث القانونيت والإقتصاديت ب مب 
تحقيق مصلحة اجتماعية مشروعة، مادامـت التدابير التي تشكل تلكك القيود تـدابير ضرورية ومتناسبة. ففي قضية, Handyside vs the United Kingdom, قضت المحكمة الأوربية بأن منع ومصادرة كتاب موجه للصغار وقد تضمن ضمن مـا تضمنه "تعليما جنسيا" لهم يشكل تداخلا ضروريا من قبل السلطات('). في نفس الاتجاه قضت المحكمة الأوربية في قضية Zana vs Turkey بأن نشر بيان يتضمن تمجيدا و إثـادة

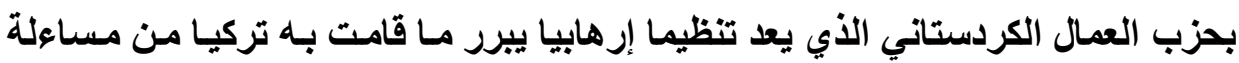

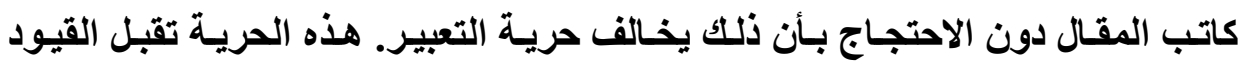
وليست من الحريات المطلقة ومن ضمن تلك القيود ما يتعلق بمكافحة الإرهـاب( (). كمـا قضت بـأن نشر خطابـات تتضمن دعوى إلى إراقة الدم والانتقـام في ظروف العنف الاخلي في تركيا لا تسري عليه أحكام حرية التعبير التي تضمنها الاتفاقية(").

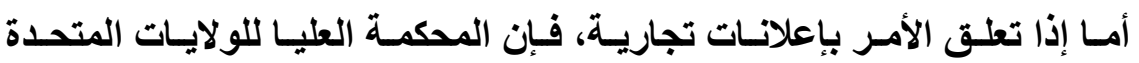

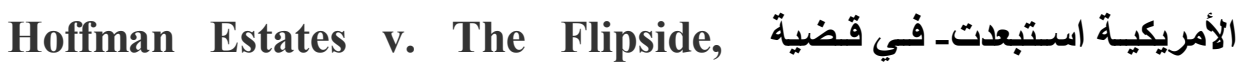
Hoffman Estates الأمر بإعلانات عن أدوات تستخدم في استعمال المخدرات("). كمـا استبعدت المحكمـة شبهة غموض النص عندما يتضمن تجريمـا للإعلان عن أدوات تستخدم في استعمال

(1) European Court of Human Rights, Handysidevs the UK, 7 December 1976, Application No. 5493/72, ECHR 5 (1976), para. 49.

(2) European Court of Human Rights, Zana vs Turkey, 25 November 1997, Application No. 69/1996/688/880, Reports 1997-VII.

(3) European Court of Human Rights, Surek vs Turkey (No. 1), 8 July 1999, Application No. 26682/95, Reports 1999-IV.

(4) Hoffman Estates v. The Flipside, Hoffman Estates 455 U.S. 489 (1982): https://supreme.justia.com/cases/federal/us/455/489/case.html 
المخدرات، ذلك أن استعمال المخدرات ليس من الغموض والاتسـاع بحيث يثكل مخالفة

$$
\text { دستورية لمبدأ شرعية الجرائم والعقوبات. }
$$

وقد أثار القانون الفرنسي الجديد مشكلة قانونية تتعلق بالحق في التعبير، حيث يبدو متعارضا مع تلك الحرية عندما يعبر شخص عن رأيه في استحسان أو تأييد أفكار الجماعات التي توصف بأنها إرهابية. وقد عُرض الأمر على المحكمة الأوربية لحقوق الإنسان واعترفت المحكمة بالصعوبات التي تعترض حريـة التعبير بسبب هذا القـانون الجديد. ومع ذلك فقد أجازت المحكمة تلكك القيود التي ترد على حرية التعبير باعتبار أن هناك ما يبرر ها في مجتمع ديمقراطي('). ثالثا- تجريم تمويل المنظمات الإرهابية وتقديم الدعم لها: أصبحت تثريعات كثيرة تعاقب على تمويل المنظمات الإرهابية ومساعدتها بـأي

$$
\text { شكل سواء أكان ذلك بتقديم أموال أو بالدعم اللوجستي. }
$$

\section{تزايد الإدراك الدولي بأهمية هكافهة تمويل التنظيمات الإرهابية:}

تزايد الاهتمام بخطورة تمويل المنظمـات الإرهابيـة على المستوى الدولي؛ فقد نصت اتفاقية سنة 999 19 بشأن مكافحة تمويل الإرهـاب على جريمـة تمويل الإرهـاب التي تسري على تمويل المنظمات الإرهابية بتعريفها بأنها تثمل "كل من يقدم أو يجمع الإبل بشكل مباشر أو غير مباشر، وبشكل مشروع أو غير مشروع بقصد استعمالها في عمل إرهابي أو مع العلم بأنها سوف تستخدم في عمل إرهابي كليا أو جزئيا مؤثم بمقتضى

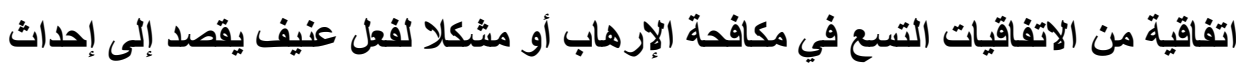
الرعب بين الناس أو إجبار السلطات على القيام بعل معين".

(1) CEDH, 2 oct. 2008, n $^{\circ}$ 36109/03, Leroy c/ France, AJDA 2009. 872, chron. J.-F. Flauss ; RSC 2009. 124, obs. J. Francillon 
وقد لوحظ أن الجماعات الإرهابية تلجـأ إلى وسـائل عديدة من التمويل الخـاص

للحصول على التمويـل بعد انحسار التمويـل العـام بسبب انحسار تورط الدول بشكل

مباشر في ظاهرة الإرهاب بسبب تلخل الأمم المتحدة ضد الدول راعية الإرهاب. من تلك الوسائل تجارة المخدرات الذي بمقتضاها يتم إدخال المال إلى الدولة عن طريق وسـائل غسل الأموال. ومن هنا كان الاهتمام بمحاربـة التظظيمـات الإرهابية عن طريق محاربـة إنـ تجارة المخدرات وعمليات غسل الأموال.

\section{المقصود بالدعم الاقدم للامنظمات الإرهابية:}

أصبحت تشريعات كثيرة تجرم صـورا عديـدة مـن دعم ومساندة التظظيمـات

الإرهابية. وتحصر تلك التشريعات هذا التجريم في تقديم الدعم المـادي. ولا يقصد بالدعم المادي الدعم المالي ولكن كل صورة من صور الدعم والذي لا يشمل التحبيذ أو الاستحسان أو حتى الاعاية للمنظمة الإرهابية. تلك الصور دخلت في حيز التجريم تحت نصوص أخرى.

من التشريعات التي تعاقب على تقديم الدعم المادي للمنظمات الإرهابية التشريع

$$
\text { الأمريكي حيث يجرم القانون الوطني الأمريكي هذه الصورة من صور التجريم. }
$$

18 U.S.C.Cي ذلك ينص الباب الثامن عشر من التقنين الأمريكي بعد تعديله \$2339B(a)(1) على هذا التجريم بقوله(' (1) "تقديم الدعم المـادي للمنظمـة الإرهابية

(1)18 U.S. Code $\S 2339 B$ - Providing material support or resources to designated foreign terrorist organizations (a)PROHIBITED ACTIVITIES. (1)UNLAWFUL CONDUCT. - Whoever knowingly provides material support or resources to a foreign terrorist organization, or attempts or conspires to do so, shall be fined under this title or imprisoned not more than 20 years, or both, and, if the death of any person results, shall be imprisoned for any term of years or for life. To violate this paragraph, =

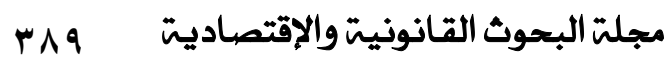


يعني أية أموال محسوسة أو غير محسوسة أو خدمة بما يتضمنه ذلك تقديم عملات أو

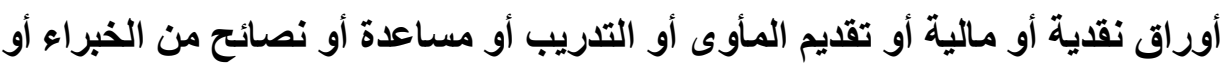
السكن الآمن أو هوية أو أوراق مزورة أو وسائل اتصال أو تسهيلات أو أسلحة أو مواد اد سـامة أو متفجرات أو أشخاص) شخص أو أكثر بمـا فيهم المتهم نفسه (أو النقل باسنثناء المواد الخاصة بالخدمة الطبية أو الدينية" ـ § 93321(b)(A) وقد فسرت

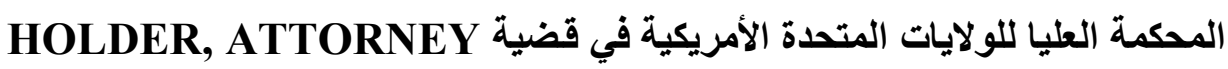
LAW TARIAN وفي قضية GENERAL, ET AL. v. HUMANIPROJECT ET AL أنه كان يدرب مندوبين من منظمة حزب العمـال الكردستاني على اللجوء إلى القـانون

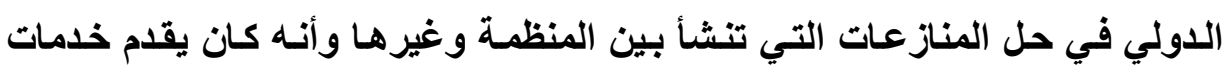
الاستثارات القانونية والمحاماة لهؤلاء المندوبين(') .وقد انتهت المحكمة إلى أن تلك لك الأنشطة تثكل تدريبا كما أنها تثكل تقديما لنصائح الخبراء وهو الأمر المعاقب عليه باعتباره دعما ماديا.

$=$ a person must have knowledge that the organization is a designated terrorist organization (as defined in subsection $(\mathrm{g})(6)$ ), that the organization has engaged or engages in terrorist activity (as defined in section 212(a)(3)(B) of the Immigration and Nationality Act), or that the organization has engaged or engages in terrorism (as defined in section 140(d)(2) of the Foreign Relations Authorization Act, Fiscal Years 1988 and 1989). https://www.law.cornell.edu/uscode/text/18/2339B

(1) HOLDER, ATTORNEY GENERAL, ET AL. v. HUMANI; TARIAN LAW PROJECT ET AL. , 2010 https://www.google.com/?gws_rd=ssl\#q=HOLDER\%2C+ATTORNEY+ GENERAL\%2C+ET+AL.+v.+HUMANI- 
وقد جرّم القانون الوطني تقديم نصائح الخبرة expert advice والمساعدة

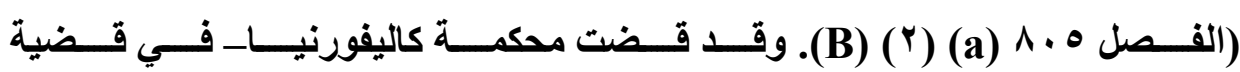
Humanitarian Law Project (HLP) v. John Aschcroft et al. الصياغة عامة وغامضة، حيث لم تحدد المادة السابقة نوع المساعدة وحيث إنها يمكن أن تخالف المادة الأولى التي تكرس الحق في التعبير('). وقد رفضت المحكمة الطعن على النص بعلم الاستورية بمقولة أن صياغته جاءت غامضة بمـا يشكل مخالفة لمبدأ الشرعية باعتبار أن ألفاظه واضحة وتشمل تقديم العون إلى المنظمـة الإرهابية مـادام أن المتهم يعلم أنها منظمـة إرهابية .كمـا رفضت المحكمة التمييز الذي اقترحه المتهم بين تقديم الدعم للقيـام بعملية إرهابية وتقديم الدعم في عمل مشروع، مـادام أن تقديم أي صورة للاعم من شـأنها أن تقوي

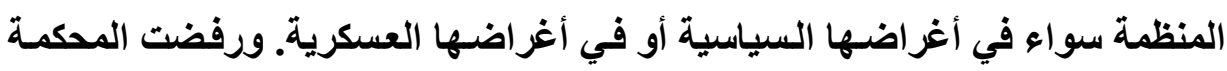
الطعن بعدم دستورية النص المستتد إلى الإخلال بالحق في التعبير باعتبار أن الرسـائل والمحادثات بين المتهم وبين المنظمـة الإرهابيـة ليس من التعبير الحر، بـل هو مؤثث بالقانون ويشكل قيدا مسموحا به في مجتمع ديمقراطي على حرية التعبير .

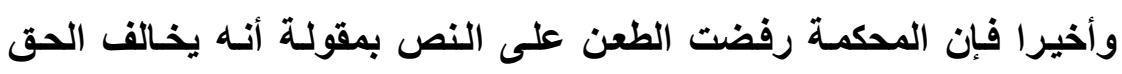
الاستوري في تكوين جمعيات والاتصال بالجمعيات باعتبار أن المحظور فقط هو الاتصال بالجمعيات الإرهابية دون سـائر الجمعيات التي لـ يحرم المتهم من تكوينها. مـن ذلك التشريعات التـي تعاقب على المساندة للتظيمسات الإرهابيـة قـانون 
العقوبات الألماني في الفصل a a r ا الذي يعاقب على أربع صور من هذا التأييد(1).

(1) Section 129a Forming terrorist organizations:

(1) Whosoever forms an organisation whose aims or activities are directed at the commission of

1. murder under specific aggravating circumstances (section 211), murder (section 212) or genocide (section 6 of the Code of International Criminal Law) or a crime against humanity (section 7 of the Code of International Criminal Law) or a war crime (section 8, section 9, section 10, section11 or section 12 of the Code of International Criminal Law); or

2. crimes against personal liberty under section 239 a or section $239 \mathrm{~b}$,

3. (repealed)

or whosoever participates in such a group as a member shall be liable to imprisonment from one to ten years.

(2) The same penalty shall be incurred by any person who forms an organisation whose aims or activities are directed at

1. causing serious physical or mental harm to another person, namely within the ambit of section 226 ,

2. committing offences under section 303b, section 305, section 305a or offences endangering the general public under sections 306 to $306 \mathrm{c}$ or section 307(1) to (3), section 308(1) to (4), section 309(1) to (5), section 313, section 314 or section 315(1), (3) or (4), section 316b(1) or (3) or section 316c (1) to (3) or section 317(1),

3. committing offences against the environment under section $330 \mathrm{a}(1)$ to (3),

4. committing offences under the following provisions of the Weapons of War (Control) Act: section19 (1) to (3), section 20(1) or (2), section 20a(1) to (3), section 19 (2) No 2 or (3) No 2, section 20(1) or (2), or section 20 a(1) to (3), in each case also in conjunction with section 21, or under section $22 \mathrm{a}(1)$ to (3) or

5. committing offences under section 51(1) to (3) of the Weapons Act; or by any person who participates in such a group as a member, if one of the offences stipulated in Nos 1 to 5 is intended to seriously intimidate the population, to unlawfully coerce a public authority or an international organisation through the use of force or the threat of the use of force, or to significantly impair or destroy the $=$ 
الصورة الأولى وتتخذ شكل إنشاء المنظمـة ذاتها الصورة الثانية، عضوية المنظمـة، الصورة الثالثة وتتخذ صورة تقديم العون إلى المنظمـة والصورة الرابعة وهي السعي إلى تجنيا أعضاء للمنظمة('). تطبيقا لذلك انتهت المحكمة الفيدرالية الألمانية في أحكام

= fundamental political, constitutional, economic or social structures of a state or an international organisation, and which, given the nature or consequences of such offences, may seriously damage a state or an international organisation.

(3) If the aims or activities of the group are directed at threatening the commission of one of the offences listed in subsection (1) or (2) above, the penalty shall be imprisonment from six months to five years.

(4) If the offender is one of the ringleaders or hintermen the penalty shall be imprisonment of not less than three years in cases under subsections (1) and (2) above, and imprisonment from one to ten years in cases under subsection (3) above.

(5) Whosoever supports a group as described in subsections (1), (2) or (3) above shall be liable to imprisonment from six months to ten years in cases under subsections (1) and (2), and to imprisonment not exceeding five years or a fine in cases under subsection (3). Whosoever recruits members or supporters for a group as described in subsection (1) or subsection (2) above shall be liable to imprisonment from six months to five years.

(6) In the cases of accomplices whose guilt is of a minor nature and whose contribution is of minor significance, the court may, in cases under subsections (1), (2), (3) and (5) above, mitigate the sentence in its discretion (section 49(2)).

(7) Section 129(6) shall apply mutatis mutandis.

(8) In addition to a sentence of imprisonment of not less than six months, the court may order the loss of the ability to hold public office, to vote and be elected in public elections (section 45(2) and (5)).

(9) In cases under subsections (1), (2) and (4) above the court may make a supervision order (section 68(1)).

(1) Till Gut, German Federal Court of Justice (Bundesgerichtshof-BGH), 3rd Criminal Senate, Promoting a Terrorist Organisation: Support versus Recruitment of Members or Supporters, Decision of 16 May= 
لها إلى أن من يقوم بوضع فيديو لزعماء القاعدة مثل بن لادن وغيرهم وهم ياعون إلى الجهاد وقتل الأعداء كما يرسل الرابط الذي يمكن الآخرين من الاخول إلى الموقع الذي حمّل عليه هذا الفيديو فإنه يرتكب الصورة الرابعة والتي تثمثل في الاعاية وتجنيد. فلا معنى لما قام به المتهم إلاً أن يكون تحبيذا لما يقوم بـه زعمـاء القاعدة وبالتـالي دعوة إلى الانضمام إلى ذلك التنظيم. وقد استبعد القضاء الألمـاني أن يقع فعل المتهم تحت طائلة الصورة الثالثة والتي تتمثل في تقديم الدعم والمساندة، وهو المقرر لهه عقوبـة أشد من عقوبـة التحبيذ. فالدعوة الضمنية إلى التجنيد أي إلى العضوية في المنظمـة

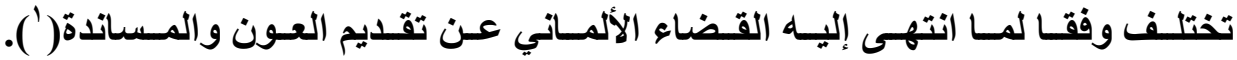
وقد أكد القضاء الألمـاني أن تقديم العون والمساندة لا يكون إلا بوسـائل ماديـة مثل تقديم المـال أو الأسلحة أو المساعدة اللوجستية)(ّ). وبهذا فـإن الدعاية والتحبيذ

$=$ 2007, Case No. AK 6/07 and StB 3/07, 71 J. Crim. L. 491 2006-2007, 71 J. Crim. L. 491 2006-2007, www.heinonline.org

(1) German Federal Court of Justice (Bundesgerichtshof-BGH), 3rd Criminal Senate, Decision of 16 May 2007, Case No. AK 6/07 and StB 3/07, 71 J. Crim. L. 491 2006-2007, 71 J. Crim. L. 491 2006-2007, BGH, 5th Criminal Senate, Decision of 28 October 2004, Case No. StB 5/04, NStZ-RR 2005, 73; www.heinonline.org

(2)see Section 129a Forming terrorist organisations

(1) Whosoever forms an organisation whose aims or activities are directed at the commission of

1. murder under specific aggravating circumstances (section 211), murder (section 212) or genocide (section 6 of the Code of International Criminal Law) or a crime against humanity (section 7 of the Code of International Criminal Law) or a war crime (section 8, section 9, section 10, section11 or section 12 of the Code of International Criminal Law); or = 
$=2$. crimes against personal liberty under section $239 \mathrm{a}$ or section $239 \mathrm{~b}$,

3. (repealed) or whosoever participates in such a group as a member shall be liable to imprisonment from one to ten years.

(2) The same penalty shall be incurred by any person who forms an organisation whose aims or activities are directed at

1. causing serious physical or mental harm to another person, namely within the ambit of section 226 ,

2. committing offences under section $303 \mathrm{~b}$, section 305 , section $305 \mathrm{a}$ or offences endangering the general public under sections 306 to $306 \mathrm{c}$ or section 307(1) to (3), section 308(1) to (4), section 309(1) to (5), section 313, section 314 or section 315(1), (3) or (4), section 316b(1) or (3) or section 316c (1) to (3) or section 317(1),

3. committing offences against the environment under section $330 \mathrm{a}(1)$ to (3),

4. committing offences under the following provisions of the Weapons of War (Control) Act: section19 (1) to (3), section 20(1) or (2), section 20a(1) to (3), section 19 (2) No 2 or (3) No 2, section 20(1) or (2), or section 20 a(1) to (3), in each case also in conjunction with section 21, or under section $22 \mathrm{a}(1)$ to (3) or

5. committing offences under section 51(1) to (3) of the Weapons Act;

or by any person who participates in such a group as a member, if one of the offences stipulated in Nos 1 to 5 is intended to seriously intimidate the population, to unlawfully coerce a public authority or an international organisation through the use of force or the threat of the use of force, or to significantly impair or destroy the fundamental political, constitutional, economic or social structures of a state or an international organisation, and which, given the nature or consequences of such offences, may seriously damage a state or an international organisation. = 
والدعوة إلى العضوية لا تعتبر وفقا للتفسير الذي خلص إليه القضاء الألماني من صور

الاعم والمساندة على الرغم من أن ذلك من شـأنه أن يقوي التنظيم الإرهـابي. ويرجع

$=(3)$ If the aims or activities of the group are directed at threatening the commission of one of the offences listed in subsection (1) or (2) above, the penalty shall be imprisonment from six months to five years.

(4) If the offender is one of the ringleaders or hintermen the penalty shall be imprisonment of not less than three years in cases under subsections (1) and (2) above, and imprisonment from one to ten years in cases under subsection (3) above.

(5) Whosoever supports a group as described in subsections (1), (2) or (3) above shall be liable to imprisonment from six months to ten years in cases under subsections (1) and (2), and to imprisonment not exceeding five years or a fine in cases under subsection (3). Whosoever recruits members or supporters for a group as described in subsection (1) or subsection (2) above shall be liable to imprisonment from six months to five years.

(6) In the cases of accomplices whose guilt is of a minor nature and whose contribution is of minor significance, the court may, in cases under subsections (1), (2), (3) and (5) above, mitigate the sentence in its discretion (section 49(2)).

(7) Section 129(6) shall apply mutatis mutandis.

(8) In addition to a sentence of imprisonment of not less than six months, the court may order the loss of the ability to hold public office, to vote and be elected in public elections (section 45(2) and (5)).

(9) In cases under subsections (1), (2) and (4) above the court may make a supervision order (section 68(1));Bundesgerichtshof, 3rd Criminal Senate, Decision of 1 March 2007, Case No. AK 1/07; 
ذللك إلى اختلاف الصورتين من صور التجريم و المقرر لكل منهمـا عقوبة منفصلة، هي أثند في حالة الاعم و المساندة عن السعي إلى التجنيا. وقد حدد الفصل 1^1 من التقتين الجنائي الأمريكي أن الدعم المسادي يشمل كل

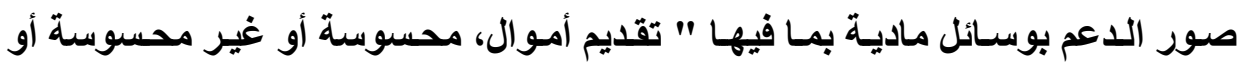
خدمات أو عملات أو أدوات نقدية أو أسهم مالية ....". وبنـاء عليه فبان من يقدم طعامـا أو مـأوى لأعضاء ذلك الته التنظيم يرتكب الفعل

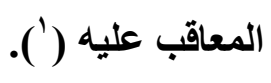

وقد عرفت المسادة الأولى مـن قـانون الكيانـات الإرهابية لسنة ه 1 ـ ب تمويل

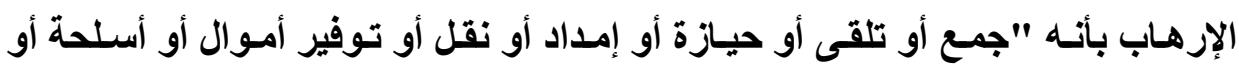

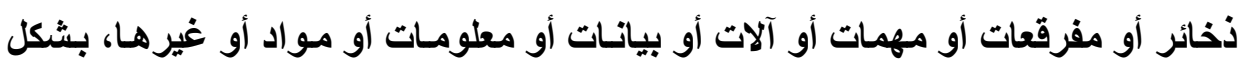

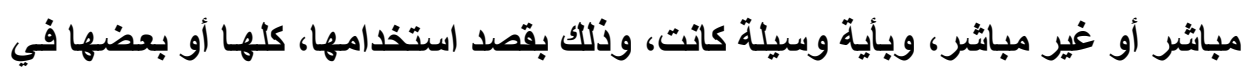
ارتكاب أيسة جريمـة إرهابيـة أو العلم بأنها ستستخدم في ذلكلك، أو بتوفير مـلاذ آمـن

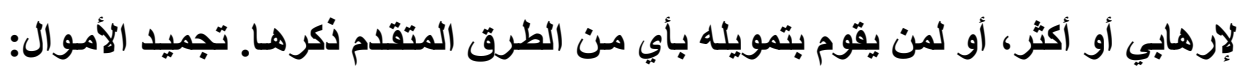

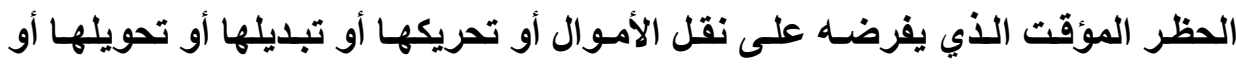
التصرف فيها، وذلك بناء على القرار الصادر وفقا لنص المادة (بّ) من هذا القانون. وعرفت المادة السابقة الأموال بأنها "جميع الأصول والمتلكات أيا كان نوعها،

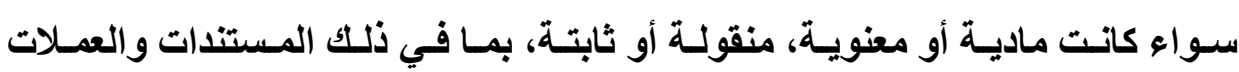

(1) Singh-Kaur v. Ashcroft, 385 F.3d 293, 301 (3d Cir. 2004); 107Jo hnson v. Eisentrager, 339 U.S. 763, 777-78 (1950); see also Kwong Hai Chew v. Colding, 344 U.S. 590,596 n.5 (1953). 
الوطنية أو الأجنبية، والأوراق المالية أو التجاريـة، والصكوك والمحررات المثبتة لكل ما تقلم أيا كان شكلها، وجميع الحقوق المتعلقة بأي منها". وقد يُنسب فعل الدعم إلى جمعيـة إذا سـاعدت منظمـة إرهابية عن طريق الدعم

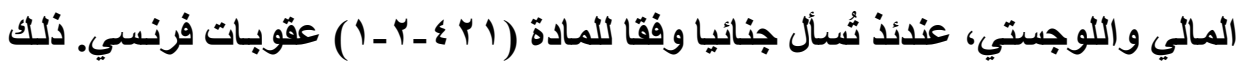

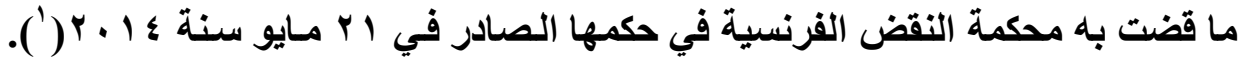
وقد صدر هذا الحكم بصدد نادي ثقافي في باريس خاص بالثقافة الكرديـة ولكن اتضح أن هذا النادي له علاقة قوية بحزب العمال الكردستاني الذي يُعد تنظيمـا إرهابيـا وفقا للقـانون الفرنسي. وقد تمثلت هذه العلاقـة في تلقي هبـات وتقديمها لحزب العمـال الكردستاني والدعاية له وكذلك توفير مكان لاجتماع أعضاء هذا الحزب به أي أنه يقدم دعما لوجستيا أيضا. فقد قضي بأن الأمر يتعلق بجريمة ارتكبها شخص معنوي وهو هذا النادي الذي شُكل في شكل شخص معنوي، كمـا تقع الجريمـة مـن أثـخاص طبيعيين هم مديرو هذا

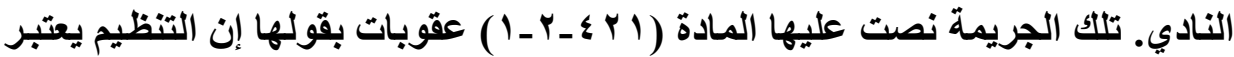
إرهابيا إذا كان الغرض منه ارتكاب جرائم إرهاب روعي فيها تخويف الناس أو إرعابهم عن طريق ارتكاب جرائم ضد الحياة أو ضد السلامة الجسمية أو ضد الأموال أو ارتكاب جرائم تتعلق بحيازة الأسلحة أو المتفجرات أو غسل الأموال أو جرائم البورصة، سواء تعلق الأمر بمشروع فردي أو بمشروع جماعي(؟َ).

(1) Crim. 21 mai 2014 , $n^{\circ}$ 13-83.758: Mélanie Bombled, Terrorisme par association de malfaiteurs en cas de soutien à une organization terroriste, Dalloz actualité 03 juin 2014

(2) Crim. 21 mai 2014, ibid

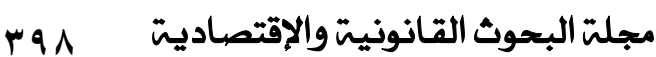




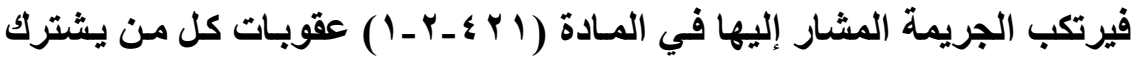

في تجمع يهدف إلى تحقيق هذه الأغراض. ولا يشترط في رأي المحكمة تقديم الدليل على أن النادي الثقافي كان يخطط لارتكاب جريمة من الجرائم المشار إليها في المـادة السابقة مادام أن مشاركته ومساعدته كاتت لتنظيم يرتكب تلكك الجرائم. وقد قضي بتوقيع عقوبة الحل على النـادي كعقوبة مقررة للشخص المعنوي

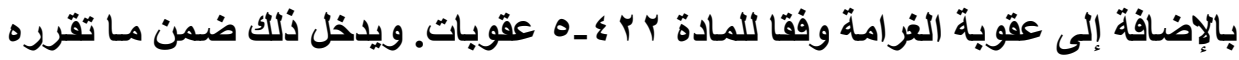

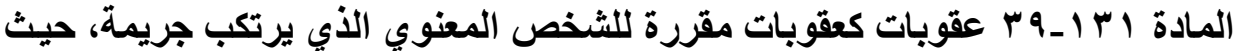
إن القانون الفرنسي يقرر المسئولية الجنائية للثخص المغنوي كقاعدة عامة في المادة

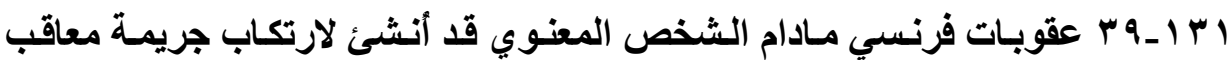

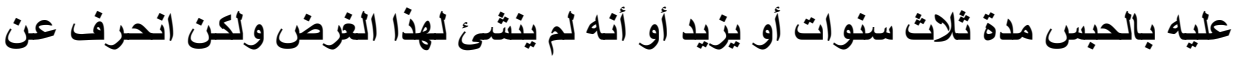
غرضه الأصلي لارتكاب جريمة معاقب عليه بعقوبة مما سبق. الاكتفاء بالقصد الجنائي العام في جريمة دعم المنظماتهات الإرهابية: لا يشترط لوقوع جريمة تقديم الدعم المـادي للمنظمـة الإرهابية توافر قصد من نوع خاص يتمثل في نية دعم أغراض المنظمة، فتقع الجريمة مع توافر القصد الجنائي المتمثل في العلم بأن المنظمة مدرجة ضمن المنظمات الإرهابية وإرادة تقديم هذا اللاعم Humanitarian Law Project v. المسادي، على مسا قضي بـه في قضية فئن سنة V Vukasey,

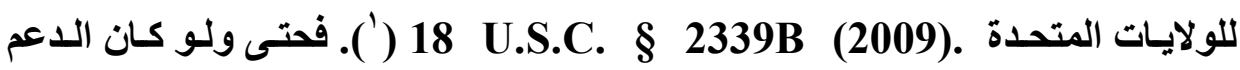

(1) See Humanitarian Law Project v. Mukasey, 509 F.3d 1122, 1130-33 (9th Cir. 2007). 
مقصودا بـه نششاط مشروع مـن نشاطات المنظــة الإرهابيـة، فِإن الجريمـة تقع رغم

كما قضي بوقوع الجريمـة حتى ولو كان قرار تحديد المنظــة بأنها إرهابية

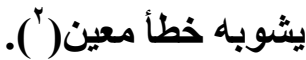

\section{تمويل الإرهاب عن طريق غنل الأهوال:}

قد تتم جريمة غسل الأموال بغرض تحقيق الكسب الامهوال المالي، وهي قد تقع في إطار

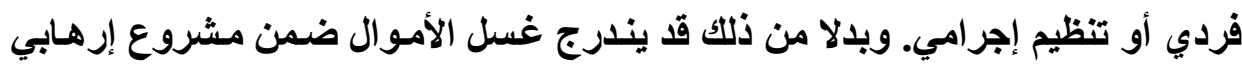

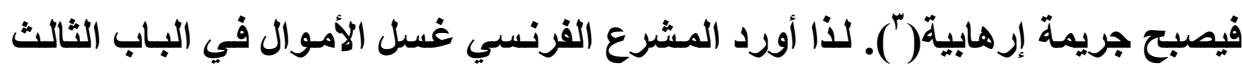

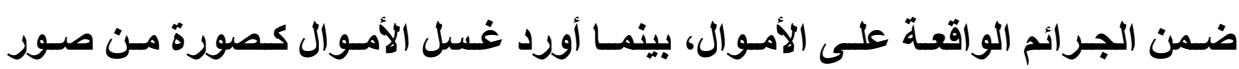
الأنثطة الإجرامية في الباب الرابع ضمن جرائم الإرهاب.

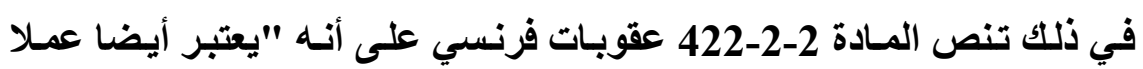

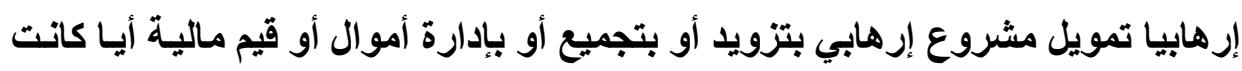

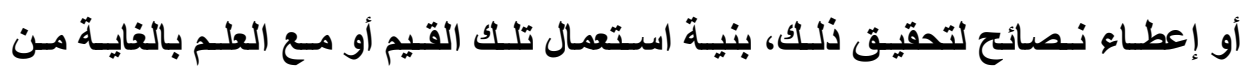
استخدامها بشكل كلي أو بشكل جزئي في ارتكاب أي من الأعمال الإرهابية المشار إليها

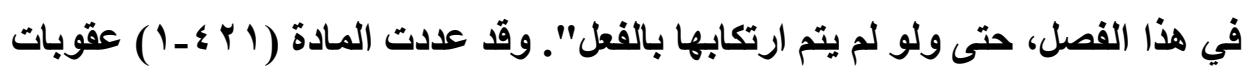

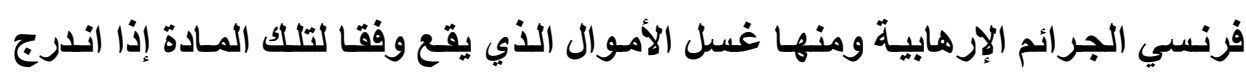

(1) Id

(2) 8 U.S.C. § 1189(a)(8) (2009); see also U.S. v. Afshari, 426 F.3d 1150 (9th Cir. 2005)

(3)Claude J. BERR, Blanchiment de capitaux et financement du térrorisme Répertoire de droit pénal et de procédure pénale, janvier 2010 (dernière mise à jour : juin 2013)

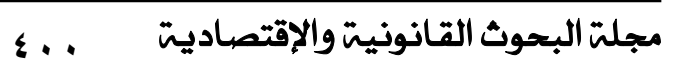


ضسن مشروع فردي أو جمـاعي الغرض منـه إحـاث اضطراب خطير للنظـام العسام بالتخويف أو الرعب.

فقد أصبحت مكافحة غسل الأموال من وسائل مكافحة الإرهاب، ذلك أنه كثيرا مـا يتخذ ذلك الغل لتمويل الإرهاب. لذا صدر قانون مكافحة غسل الأموال في الولايـات المتحدة لسنة ا . . r. وقد وسع القانون الوطني الأمريكي من مجال اختصاص المحسكم الأمريكية لنظر جرائم غنل الأموال متى تمت كلها أو بعض في إقليم الدولة أو تم إخفاء حصيلة الغسل كله أو بعضه في أمريكا أو إذا كان البنك أو الجهة المالية التي لها علاقة

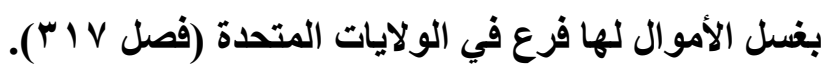
وقد تم التوسع في مجال تطبيق قانون مكافحة غسل الأموال ليشمل الجرائم

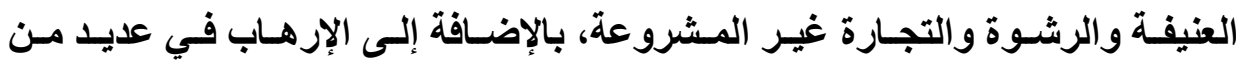

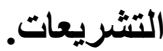
من التشريعات السابقة القانون الاتحادي في الإمارات رقم (־آ) لسنة ؛ . . ب في شأن مكافحة الجرائم الإرهابية التي تعاقب بالإعدام أو السجن المؤيد كل من أنشأ أو الأ أسس أو نظم أو أدار جمعية أو هيئة أو منظمة أو مركزاً أو جماعة أو عصابة أو تولى الإعدام الوالئ زعامة أو قيادة لها بغرض ارتكاب أحد الأعمال الإرهابية المنصوص عليها في هذا القانون... (مادة َ). وتنص المادة (؛) من القانون السابق على أنه "يعاقب بالسجن

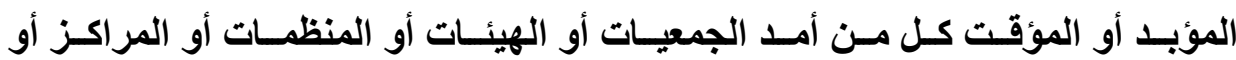

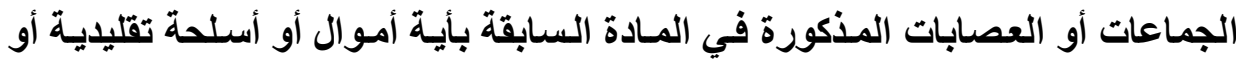
غير تقليدية أو غيرها من المواد التي تعرض حياة النـاس أو أمو الهم للخطر... ممـا يعينها على تحقيق أغراضها مـع علمها بذلكل". كما تعاقب المسادة (r ا ) من القانون

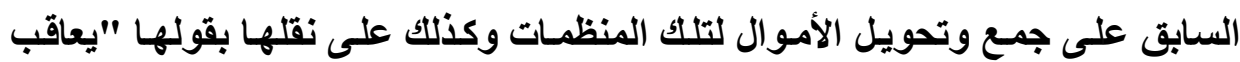


بالسجن المؤبد أو المؤقت كل من اكتسب أو قدم أو جمع أو نقل أو حول أموالا بطريق

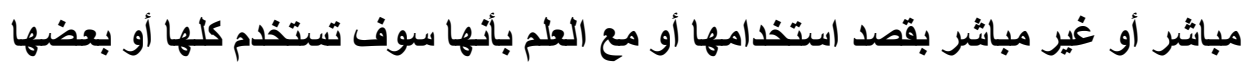
في تمويل أي من الأعمال الإرهابية المنصوص عليها في هذا القانون".

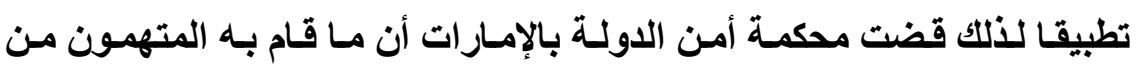
نثاط دعوى وجمع أموال بقصد تقديمها إلى جماعات تسعي إلى تحرير العراق من

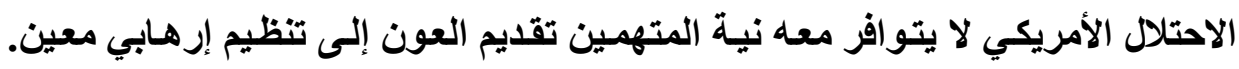

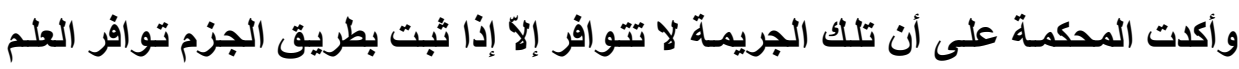

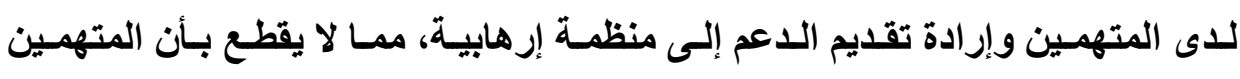

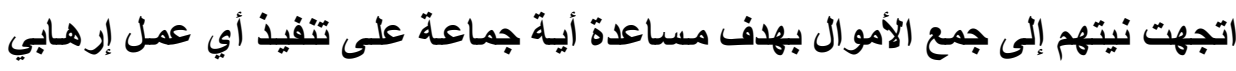

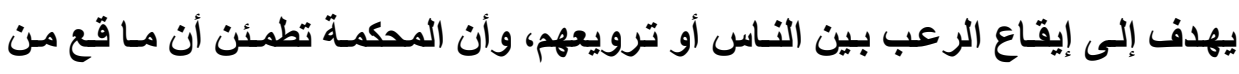

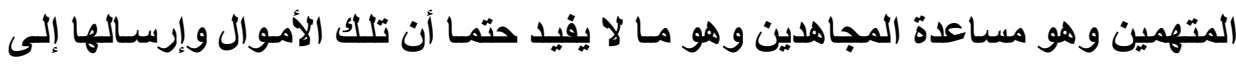
العراق تلبية لأمر حمله اعتقادهم عليه و هو مساعدة المجاهدين و هو ما لا يفيل حتما أن

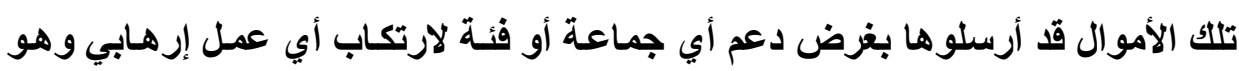

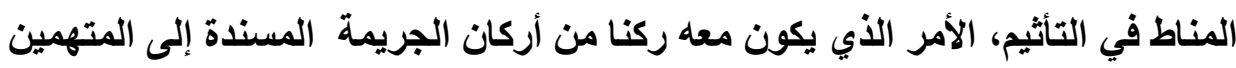

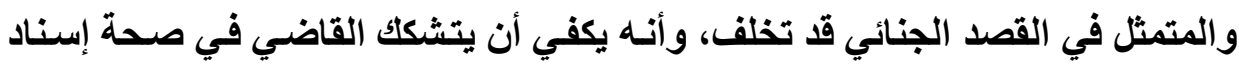

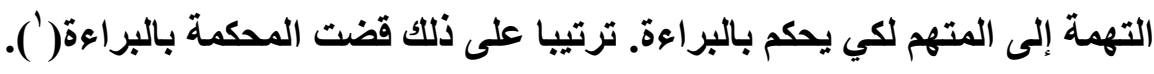

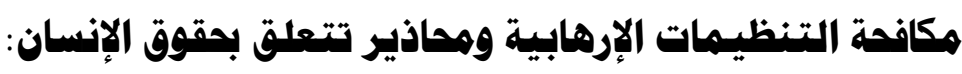

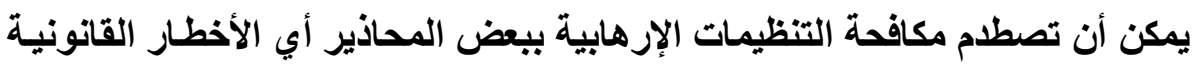
التي تتعلق بحقوق الإنسان. فهنـاك مبدأ الشرعية الذي يستوجب تعريف المنظمـة 
الإرهابية بشكل دقيق يتمشى مع ما للقانون الجنائي من دقة في التحديد تنفي أي جهالة احتر اما للحقوق الفردية وصونـا لها من كل افتئات. وهناك حقوق دستورية أخرى يتعين احترامها عند القيام بهذا التجريم؛ منها شخصية المسئولية حيث يتحمل عضو التنظيم الإرهـابي المسئولية الجنائية عمـا يرتكبه غيره مـن أعضاء التظظيم، ومنها ضرورة احترام الحق في تكوين جمعيات. وهناك الحق في التعبير الذي يصطدم بتجريم التعبير عن أفكار معينة عند وصفها بأنها إرهابية وبالتالي لا تخرج عن مضمون الحق في

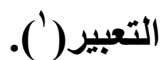

\section{الإطالب الثاني}

اعتماد السياسة الجنائية على قواعد جديدة

في التجريم

تعتمد السياسة الجنائية الحديثة على مجموعة من القواعد تختلف عما هو مقرر وفقا للقواعد العامة التقليدية؛ من هذه القواعد:

\section{أولاً - تجريم أفعال الفطر وعدم اشتراط وقهع البريمة:}

تتجه التشريعات المقارنة إلى النص على وقوع الجرائم المرتبطة بالتظيمـات

الإرهابية. فلا يلزم لوقوع جريمة إنشاء تنظيم إرهابي أو العضوية في تنظيم إرهابي أو تمويل هذا التظظيم أو الترويج له أو غيرها من الجرائم المرتبطة بالتنظيم وقوع جريمـة

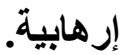

(1) Dianne Otto ,PROTECTING HUMAN RIGHTS AND COUNTERING TERRORISM: AUSTRALIA'S CONTRADICTORY APPROACHES TO IMPLEMENTING ITS INTERNATIONAL LEGAL OBLIGATIONS, 44 Val. U. L. Rev.(VALPARAISO UNIVERSITY LAW REVIEW [Vol.44) 911 2009-2010.

مجلتّ البحوث القانونيت والإقتصاديت ب . ؛ 
من ذلك أن المـادة (7) مـن قانون مكافحة الإرهـاب لسنة ه 1 ـ ب تعاقب على الاتفاق أو المساعدة على ارتكاب الجريمة الإرهابية بذات العقوبة المقررة للجريمة ولو لم تقع بقولها: "كما يعاقب بذات العقوبة المقررة للجريمة التامة كل من اتفق أو سـاعد بأية صورة على ارتكاب الجرائم المشار إليها بالفقرة الأولى من هذه المادة ولو لم تقع الجريمة بناء على ذلك الاتفاق أو تلك المساعدة". ونرى أن النص السابق غير دستوري ذلك أنها يتــافى مـع مبدأ تناسب العقوبـة عندما قرر عقوبة الجريمة التامة لمجرد الاتفاق أو المساعدة على الجريمة. ومن جرائم الخطر التي أخذ بها قانون مكافحة الإرهـاب لسنة ه 1 ـ ب مـا نصت عليه المـادة (r I ) مـن تجريم الانـضمام إلى تنظيم إرهـابي حيث تعاقب على مجرد الانضمام دون ارتكـاب جريمـة معينة. كمـا أن المـادة (س ا ) من القـانون السابق تعاقب على جريمة التمويل دون اشتراط ارتكاب جريمـة معينة بنـاء على ذلتك التمويل. وذات الأمر يُقال عن جريمة التدريب أو التدرب على يد تنظيم إرهابي (مسادة هـ من القانون السابق) وجريمـة التـرويج لفكر المنظمـات الإرهابيـة (مسادة Y^) وجريمـة تجميـع معلومات عن أحد القائمين بتطبيق القانون أو تنفيذه "بغرض استخدامها في تهديده أو في الإعداد لإلحاق الأذى به أو بمصالحه أو مصالح جهة عمله أو التعدي عليه أو على أي من أصوله أو فروعه بأية صورة من صور الإيذاء" (مـادة اس من قانون مكافحة الإرهاب) وجريمة إنشاء موقع إلكتروني أو الاخول بغير حق إلى موقع إلكتروني تـابع لأية جهة حكومية بقصد الحصول على البيانـات الموجودة عليه أو الاطلاع عليها أو تغييرها أو محوها أو إتلافها أو تزويرها(').

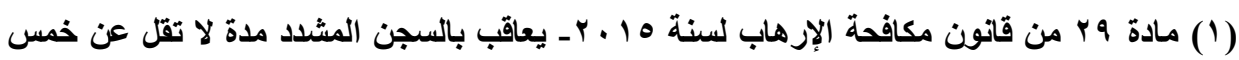

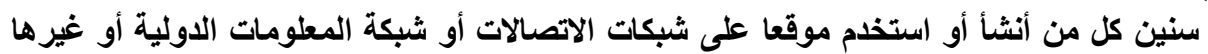

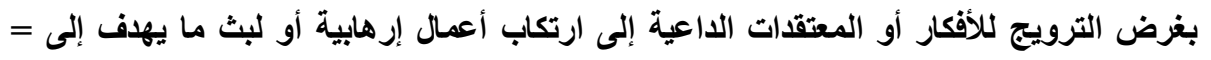




\section{ثانياً- تجريم الأعمال التحضيرية في الجرائم المتعلقة بالتنظيسات الإرهابية:}

\section{الاتجاه المعاصر نهو تجريم الأعمال التحضيرية في هجال التنظيسهات الإرهابية:}

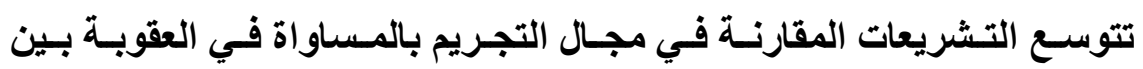

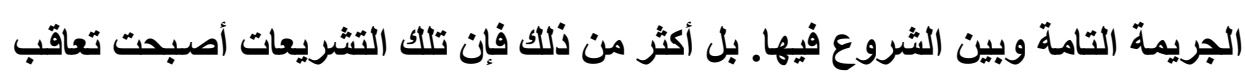
على الأعمال التحضيرية التي هي لا عقاب عليها وفقا للقو اعد العامة.

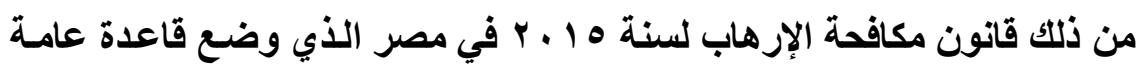

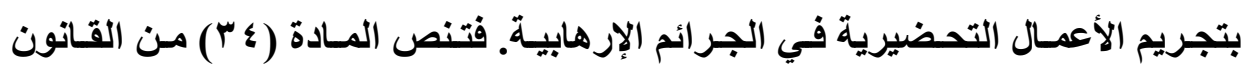

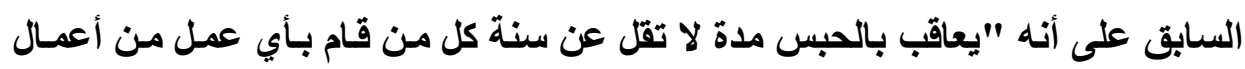
الإعداد أو التحضير لارتكاب جريمة إرهابية حتى ولو لم يتعد عمله هذا الإعداد أو

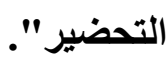

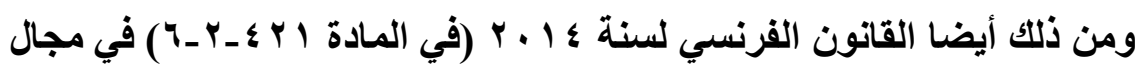

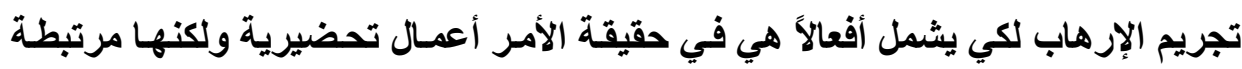
بمشروع إرهابي فردي، من تلك الأعمال: 1- حيازة أو محاولـة الحصول على أو تصنيع أثشياء أو مواد من شـأنها أن تخلق

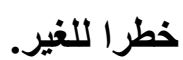

و = تضليل السلطات الأمنية أو التأثير على سير العدالة في شأن أي جريمة إرهابية أو لتبادل الرسائل

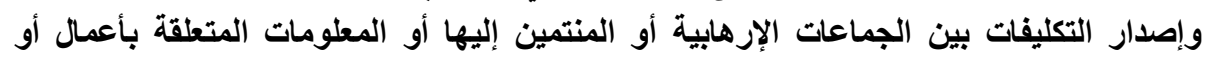

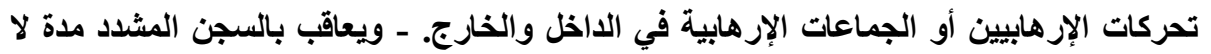

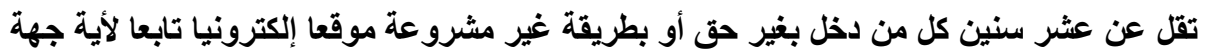

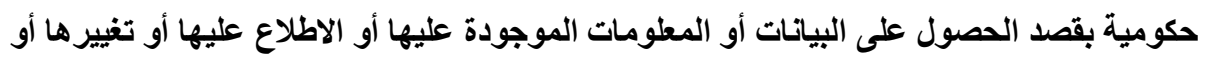

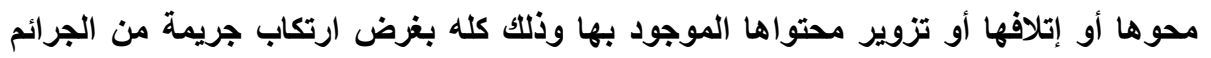
المشار إليها بالفقرة الأولى من هذه المادة أو الإعداد لها". 


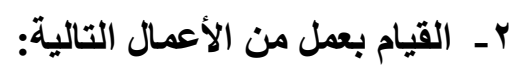

أـ جمع معلومات عن أماكن وعن أثياء أو أشخاص تسمح بالقيام بأعمال في تلك التك

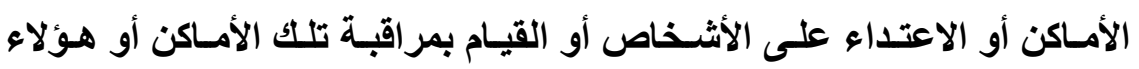

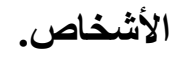

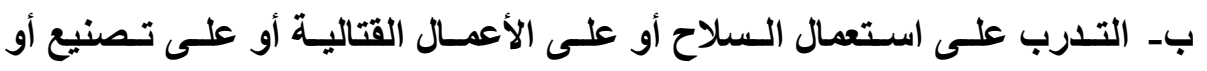

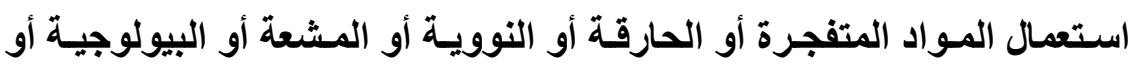
الكيمائية أو على قيادة الطائرات أو قيادة السفن.

جـ استعمال شبكة الانترنت بشكل معتاد أو حيازة مستندات تحرض على الإرهاب أو

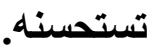

$$
\text { دـ الإقامة خارج البلاد في أماكن تعد مسرحا لعمليات إرهابية. }
$$

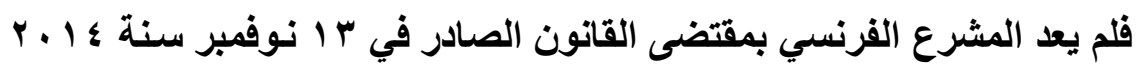

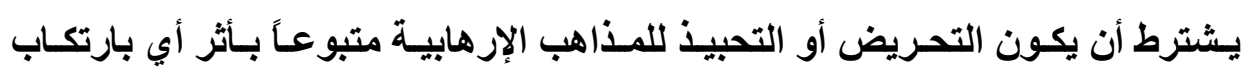

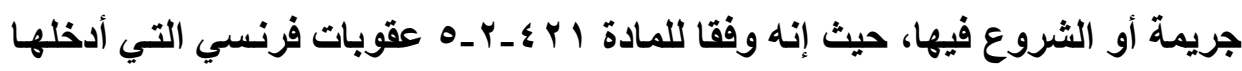

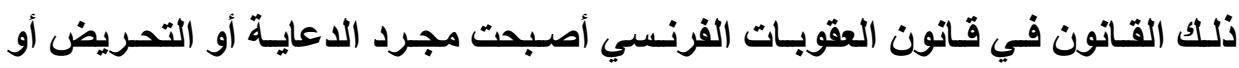

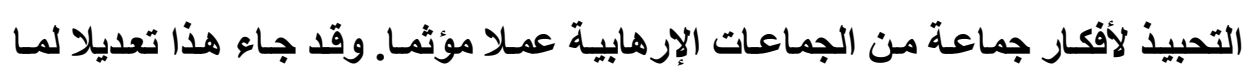

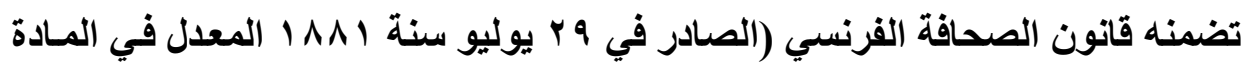

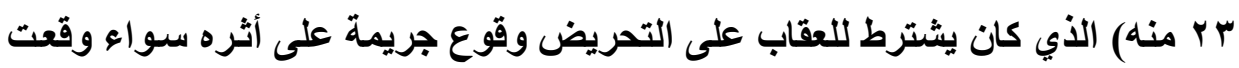




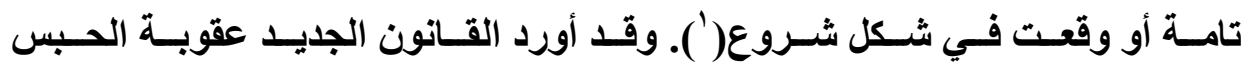

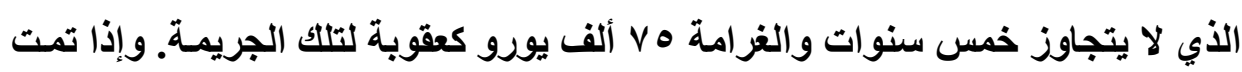

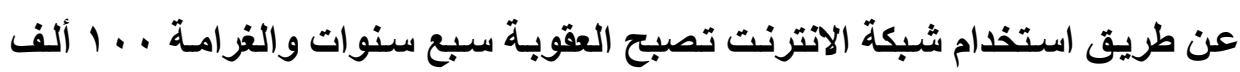

وقد أخضع القانون الفرنسي تلك الجريمة للنظام القانوني لجرائم الإرهاب، غير

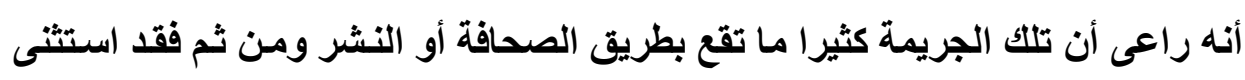

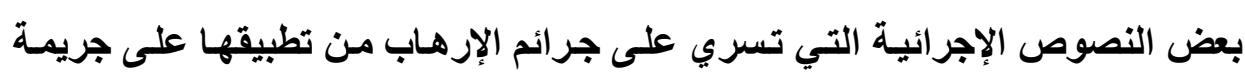

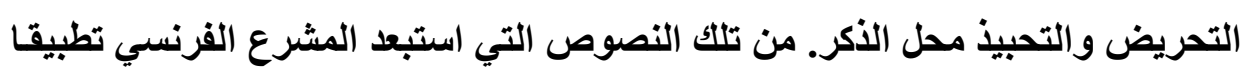

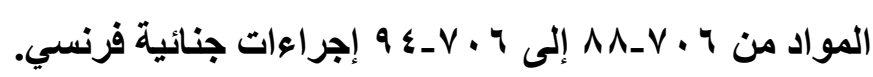

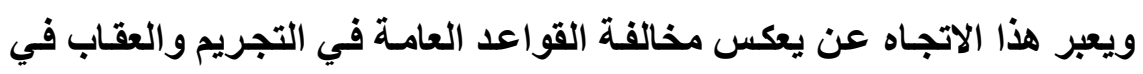

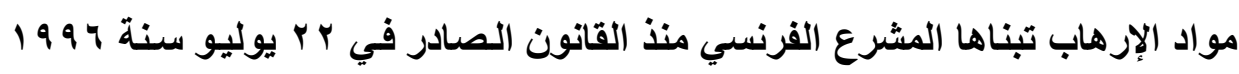

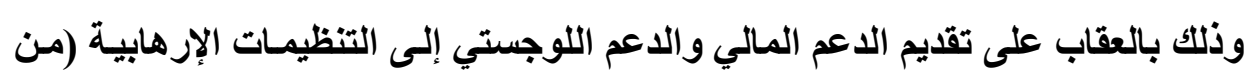

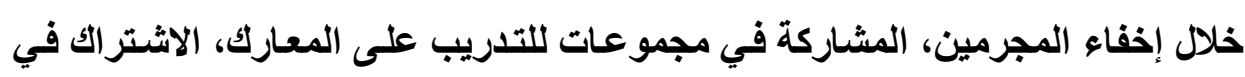

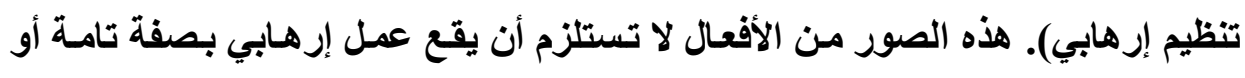

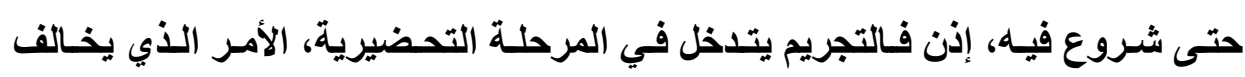
القواعد العامة في تجريم الثروع في الجريمة.

(1) Céline Godeberge, Emmanuel Daoud, La loi du 13 novembre 2014 constitue-t-elle une atteinte à la liberté d'expression, De la nouvelle définition de la provocation aux actes de térrorisme et apologie de ces actes, AJ Pénal 2014 p. 563. 


\section{هبدأ الشرعية وتجريم الأعمال التحضيرية:}

بعد أن بدأت تظهر في التشريعات العديثة جرائم تتعلق بالإرهـاب وهي في الحقيقة تتكون مـن أعمـال تحضيرية ولا ترقى إلى البداء في التنفيذ، فِان إثـكالات قانونية تتعلق باحترام مبأ الثرعية الجنائية أصبحت محلا للمناقشة. من ذلك تجميع بيانات عن تصنيع المتفجرات، تجميع بيانات عن أماكن تواجد محولات الكهرباء، رصد أمسكن عمل ومسساكن رجـال الشرطة، الاستعداد للسفر إلى أمساكن تواجد التنظيمـات الإرهابية، مراسلة أعضاء في تلكك المنظمات سواء بالبريد الاكتروني (الايميل) أو عن طريق الفيسبوك أو غيرها من وسائل التواصل الاجتماعي('). ُشضاف إلى ذلكك تجريم أعمال التجهيز والإعداد ( مادة 221-25 عقوبات فرنسي).

ثالثاً- فرض واجب التعاون هع السلطات:

تتجـه التشريعات إلى إلزام الشخص العـادي بـالتبليغ عن جرائم التنظيمـات الإرهابية لتفادي الخسائر الثديدة في الأرواح والممتلكات والتي يمكن أن تتحقق لو لو تأخر ذلك التبليغ. هذا الواجب لا يقتصر إذن على الموظفين العموميين الذين يلتزمون

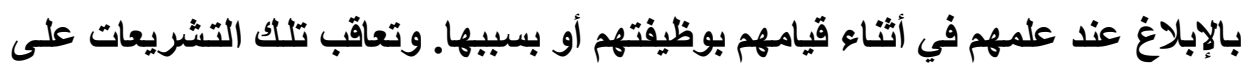
الإخلال بهذا الواجب من جانب الأفراد بعقوبة جنائية.

من ذلك أن قانون مكافحة الإرهاب في مصر لسنة ه 1 ـ ب قد نص في المسادة

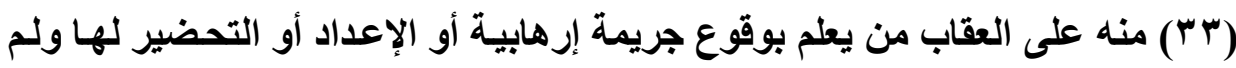

(1) GUILT BY ASSOCIATION The 'anti-terrorism' case of Regina $\mathbf{v}$ Lodhi SARAH SORIAL, : 32 Alternative L.J. 160 2007: http://heinonline.org.

مجلتّ البحوث القانونيت والإقتصاديت 
يقم بالتبليغ عنه بقولها ـ يعاقب بالحبس مدة لا تقل عن ثلاثة أثشهر وبغرامة لا تقل

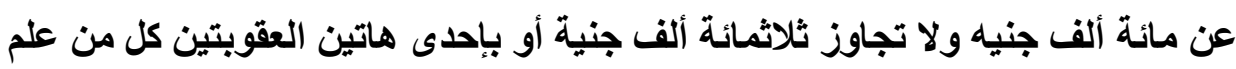
بوقوع جريمة إرهابية أو بالإعداد أو التحضير لها أو تو افرت لايه معلومـات أو بيانـات تتصل بأحد من مرتكبيها وكان بمكنته الإبلاغ ولم يبلغ السلطات المختصة". ولكنها استثت من ذلك زوج وزوجة الجاني وكنلك أصوله وفروعه. ونظراً لأهمية التبليغ في هذا النوع من الجرائم قرر المشرع المصري في قانون مكافحة الإرهاب مكافأة لمن يقوم من الجناة بالتبليغ عن الجريمة الإرهابية في صورة لهرة

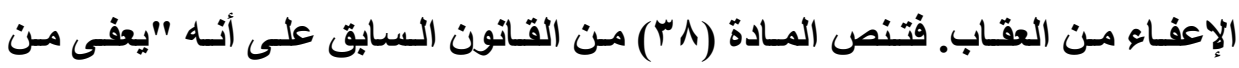
العقوبات المقررة للجرائم المشار إليها في هذا القانون كل من بادر من الجناة بإبلاغ السلطات المختصة قبل البدء في تنفيذ الجريمة ويجوز للمحكمة الإعفاء من العقوبة إذا حصل البلاغ بعد تنفيذ الجريمة وقبل البدء في التحقيق وذلك إذا مكن الجاني السلطات

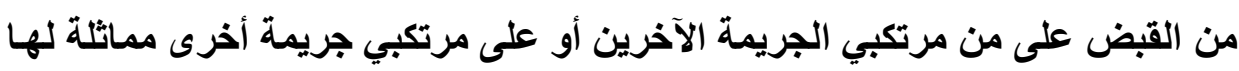
في النوع والخطورة.

رابعاً- المسئولية الجنائية للشخص المعنسوي وهسئولية هـدير التنظيم عن

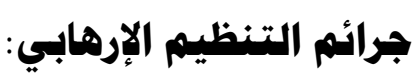

تأخذ التشريعات المختلفة بمبأ المسئولية الجنائية للثخص المعنوي المنوي حتى يقوم بتوقيع جزاءات على تلك التنظيمات. من تلك الجزاءات إدراجها على القائمسة السوداء

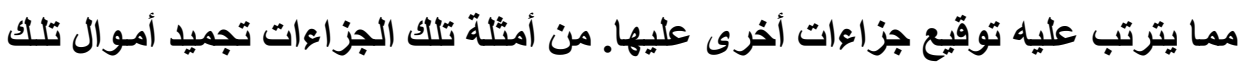

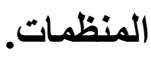


من تلك التشريعات قانون مكافحة الإرهاب في مصر لسنة ه 1 ـ ب الذي يقرر تـابير تخاطب الشخص المعنوي. مـن تلك التـابير مـصادرة الأمـوال وحل الجماعـة الإرهابية وإغلاق مقار ها في الاخل والخارج وإغلاق أماكن تصنيع أو تصميم الأسلحة. فتنص الماد (q ؟) من القانون السابق على أنه " مع عدم الإخلال بحقوق الغير حسنة النية تقضى المحكمة في كل حكم يصدر بالإدانة في جريمـة إرهابية فضلا عن العقوبـة المقررة للجريمة بمصادرة الأموال والأمتعة والأسلحة والأدوات والمستتدات وغيرهـا ممـا استخلم في ارتكـاب الجريمـة أو تحصل عنهـا وبحل الجماعة الإرهابية وإغلاق مقارهـا وأمكنتهـا في الـاخل والخـارج فضلا عن إغلاق أي مكـان تـم فيسه تصنيع أو تصميم الأسلحة بمختلف أنواعها المستخدمة في ارتكاب أيـة جريمـة إرهابيـة وغيرهـا مما يكون قد استعمل أو أعد للاستعمال من قبل الإرهابي أو الجماعة الإرهابية..- كما تقضى المحكمة عند الحكم بالإدانة بمصادرة كل مال متى ثبت أنه كان مخصصا للصرف منه على الأعمال الإرهابية". - مل

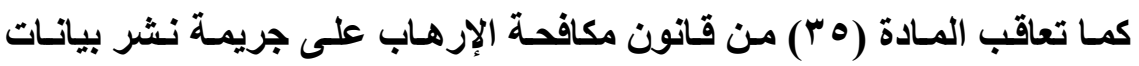
كذابة عن عمليات إرهابية، وتقرر عقوبات للثخص المعنوي بقولها "ـ يعاقب بغرامـة لا تقل عن مائتي ألف جنيه ولا تتجـاوز خمسمائة ألف جنيه كل من تعمد بـأي وسيلة كاتت نشر أو إذاعة أو عرض أو ترويج أخبار أو بيانات غير حقيقية عن أعمال إرهابية وقعت داخل البلاد أو عن العمليات المرتبطة بمكافحتها بمـا يخالف البيانـات الرسمية الصادرة عن وزارة الدفاع وذلك كله دون إخـلال بالعقوبـات التأديبية المقررة - وفي الأحوال التي ترتكب فيها الجريمة بواسطة شخص اعتباري يعاقب المسئول عن الإدارة الفعلية لهذا الثخص بذات العقوبة المقررة في الفقرة الأولى من هذه المـادة مـا دامت 
الجريمة قد ارتكبت لحسابه أو لمصلحته ويكون الثخص الاعتباري مسئولا بالتضامن عما يحكم به من غرامات وتعويضات"

كمـا قررث المـادة (r I ) مـن القـانون السابق مسئولية الشخص المسئول عن

الجماعة الإرهابية عن جريمة تمويل الإرهاب التي وقعت لحساب تلكك الجماعة. فتنص المـادة السابقة على أنـه "وفى الأحوال التي ترتكب فيهـا الجريمـة بواسطة جماعـة إرهابية يعاقب المسئول عن الإدارة الفعلية لهذه الجماعة بالعقوبة المقررة في الفقرة السابقة من هذه المادة ما دامت الجريمة قد ارتكبت لحساب الجماعة أو لمصلحتها". وجدير بالملاحظة أن العقوبات المقررة شديدة واضح؛ فهي السجن المؤبد وتصل إلى الإعدام إذا كـان لجماعة إرهابية أو لعمل إرهـابي، إدراكـا من المشرع لأهميـة تمويلـ التنظيمات الإرهابية والأعمال الإرهابية. أما الثخص المعنوي ذاته أي الجماعة أو التنظيم فإنه يعاقب بغرامة لا تقل عن مائة ألف جنيه ولا تزيـا على ثلاثذة ملايين من الجنيهات بالإضـافة إلى التضامن مـع المسئول عنها. فتنص المادة السابقة على أنه "كما تعاقب الجماعة الإرهابية بغرامـة لا تقل عن مائه ألف جنيه ولا تجاوز ثلاثة ملايين جنيه وتكون مسئوله بالتضامن عن الوفاء بما يحكم به من عقوبات مالية أو تعويضات". وأخذا باتجـاه المشرع المصري في عدم تبنـى المسئولية الجنائية للشخص المعنوي كقاعدة عامـة في جرائم الإرهـاب، نص قـانون مكافحة الإرهـاب علىى عقوبـة تصل إلى الإعدام في حالة القيام بعمل إرهابى. أما الجماعة الإرهابية ذاتها فإنها تعاقب بالغرامة من مائة ألف جنيه ولا تجاوز ثثلاثة ملايين جنيه، بالإضـافة إلى التضامن في الوفاء بالعقوبات المالية والتعويضات. فتتص المادة (9 1) من القانون السابق على أنه 
"كمـا تعاقب الجماعـة الإرهابيـة بغرامـة لا تقل عن مائسه ألـف جنيـه ولا تجـاوز ثلاثـة ملايين جنيه وتكون مسئولة بالتضامن عن الوفاء بمـا يحكم بـه من عقوبـات مالية أو تعويضات".

أما المسئول عن إدارة الجماعة الإرهابية، فإنه يعاقب بالعقوبة المقررة للجريمة مادامت الجريمة قد ارتكبت لحساب تللك الجماعة أو لمصلحتها. فتنص المادة (9 1 ) من القـانون السابق على أنـه "وفي الأحسوال التي ترتكب فيهـا الجريمـة بواسطة جماعـة إرهابية يعاقب المسئول عن الإدارة الفعلية لهذه الجماعة بالعقوبـة المقررة في الفقرة

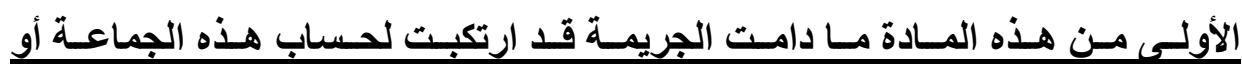
لمصلحتها".

قد يبدو هذا النوع من المسئولة التي تقع على عاتق مدير التنظيم عن الأعمال الإرهابية التي يرتكبها أفراد التظظيم مخالفـا لمبدأ المسئولية الجنائية الثخصية الذي يقـرره الاسـتور المسصري (مسادة ه9) والـذي يـشكل قاعدة مستثرة في المسئولية الجنائية. غير أن الاتجاه السائد في القوانين المقارنـة تتجـه إلى تقرير هذا النوع من المسئولية على أساس من المسئولية الشخصية وهي علم وموافقة رئيس التنظيم على ارتكاب التظيم أعمالاً إرهابية وبالتالي فإن دعائم المسئولية الشخصية متوافرة في حق مدير التظيم عما يرتكبه تنظيمه من أعمـال إرهابية ولو لم يتم الاتفـق عليها تحديدا. فإذا كان هناك اتفاق على أن يقوم التنظيم بأعمال إرهابية مثل تفجير الكباري ومحطات الكهرباء وقامت إحدى الخلايا التابعة للتنظيم بوضع قنبلة في مكان عام تسبيت في قتل عديد من الأثخاص، فإن من قام بزرع القتبلة مسئول وكذلك مدير التظيم على الرغم من الاتفاق المبدئي كـان محلـه تفجير الكبـاري والمنشآت العامـة. وهذا مـا يبرز ذاتيـة 
المسئولية الجنائيسة في مجـال جرائم التظظيم الإرهـابي. ولا يخفى أن شخصية مدير التظيم هي من الخطورة بحيث لا تقل في إجرامها عن إجرام أعضائها، فهو يمثل شخصية المنشئ والمفتي والمدبر والمخطط و الممول والوسيط مع تنظيمات إرهابية أخرى بعضها ذات طابع دولي. وبدون هذا المدير ينفرط عقد التنظيم الذي قد يتثكل من خلايا عنقودية لا يعرف بعضها البعض لا يجمعها سوى هذا المدير. هذا النوع من المسئولية عن النتائج الاحتمالية يتفق مـع مـا هو مقرر في

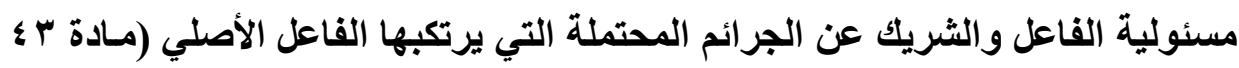

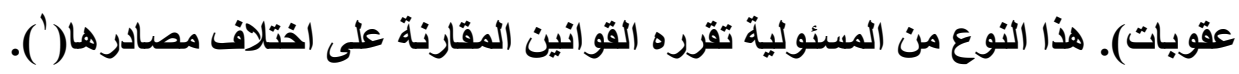

\section{سابعاً- استبعاد التقادم في جرائم الإرهاب:}

في إطار ذاتية المسئولية الجنائية في جرائم الإرهاب، قرر المشرع المصري في قانون مكافحة الإرهـاب حكما يخرج بـه عمـا تقرره القواعد العامة في التقادم. فتقرر

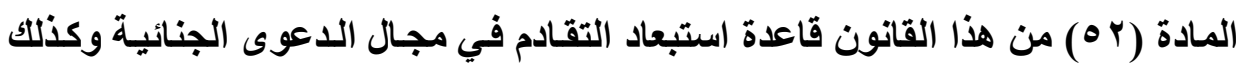

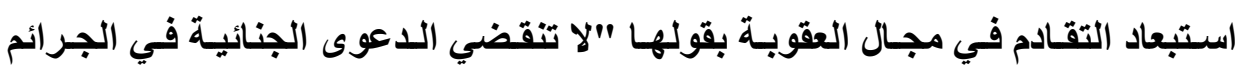
الإرهابية ولا تسقط العقوبة المحكوم بها فيها بمضي المدة".

وتتمشى تلك الأحكام مع ما تقرره قواعد القانون الدولي في خصوص الجرائم الدولية من عدم تقادم الدعوى الجنائية عن تلك الجرائم (†). أمسا عدم تقادم العقوبة،

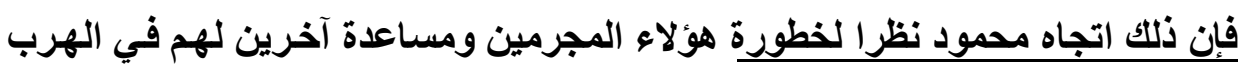
(1) انظر : د. محمود نجيب حسني، المساهمة الجنائية في التشريعات العربية، دار النهضة العربية،

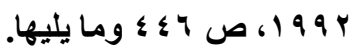

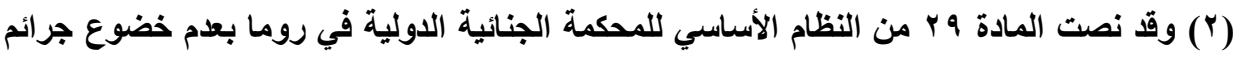
الإبادة الجماعية والجرائم ضد الإنسانية وجرائم الحرب لنظام التقادئ النقام : 
ذلك اتجاه محمود نظر الخطورة هؤلاء المجرمين ومساعدة آخرين لهم في الهرب في خارج البلاد. فمن شـأن عدم تقادم العقوبـة أن يستمر العقاب مستحق التنفيذ في أي وقت. ومن هنا أيضا لا يكون ضروريا تقرير وقف التقادم لمن يهرب إلى الخـارج وذلك للحيلولـة دون اكتمـال التقــادم كمـا هـو الشأن في عقوبـة الجـرائم الأخرى. فِإذا كـان المشرع المصري قد قرر وقف التقادم في حالة الهرب إلى الخارج، فإن ذلك كان بهدف الحيلولـة دون أن يستقيد المجرم مـن تقـادم العقوبـة (مسادة 532 مـن ق.الإجـراعات المصري). أمسا وقد قرر المشرع اسـتبعاد التقـادم أصـلا، فإنـهـ لا محل لتطبيق وقف

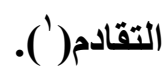




\section{المبحث الثاني \\ الجزاءات والتدابير التي توقع على التنظيسهات الإرهابية \\ وأعضائها}

يترتب على إدراج منظمة معينة على قائمة الإرهاب تو افر شرط مسبق لكثير من

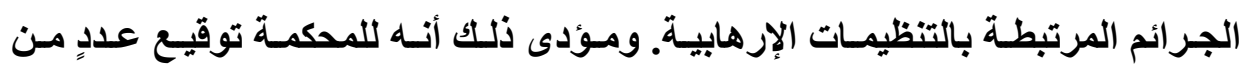
العقوبات والتدابير الاحترازية. بل يضاف إلى ذلك أن هناك من التدابير مـا يترتب دون صدور حكم قضائي بالإدانة في جريمة من الجرائم المتعلقة بالتنظيمات الإرهابية. التدابير المتزتبة على اعتبار التنظيم إرهابيا في التشريع المبري:

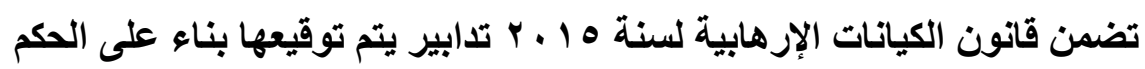

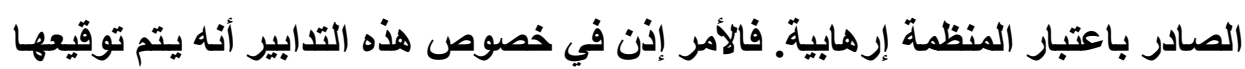
كتدابير تبعية للحكم الصادر بالإدراج. وقد جاء القانون المصري مقتديا في تلك القلسفة بما كان قد استقر في القانون المقارن سواء أكان القانون الأمريكي أم الإنجليزي أم الألمـاني أم الفرنسي من إلخال

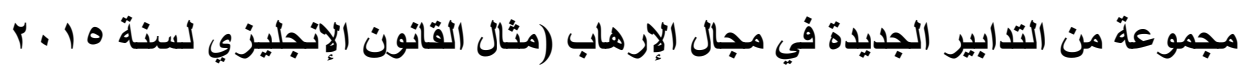
بعنوان Counter Terrorism and Security Act وضع قيود على السفر إلى منى الخارج: الجزء الأول، الفصل الأول، وقانون العقوبات الفرنسي قرر حظر الخروج من لـان

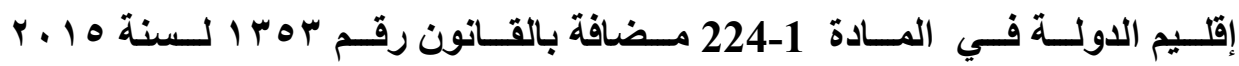

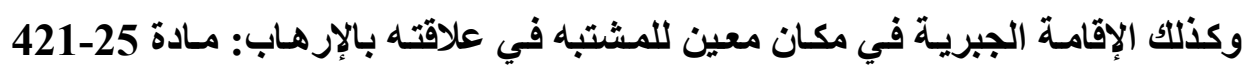

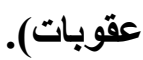




$$
\text { فتنص المادة (V) من قانون الكيانات الإرهابية لسنة ه } 1 \text { ـ ب على أنه: }
$$

تترتب بقوة القانون على نشر قرار الإدراج، وطوال مدتـه، الآثار التاليـة مـالم تقرر الـائرة المنصوص عليها في المـادة ب مـن هذا القـانون خـلاف ذلك، فبالنسبة

$$
\text { للكيانات الإرهابية: - تلفرد }
$$

1 - - حظر الكيان الإرهابي ووقف أنشطته.

r- غلق الأمكنة المخصصة له وحظر اجتماعاته.

r- حظر تمويل أو جمع الأموال أو الأشياء للكيـان سـواء بشكل مباشر أو غير

$$
\text { مباشر. }
$$

ع ـ تجميد الأموال المملوكة للكيان، أو لأعضائه متى كانت مستخدمة في ممارسـة

$$
\text { النشاط الإر هابي. }
$$

هـ حظر لاتضمام للكيـان أو الـاعوة إلى ذلتك أو الترويج لـه أو رفع شـعاراته.

$$
\text { وبالنسبة للإزر هابيين: }
$$

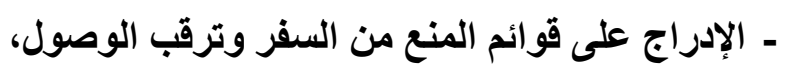$$
\text { - أو منع الأجنبي من دخول البلاد }
$$

- سحب جواز السفر أو إلغاؤه، أو منع إصدار سفر جديد

ـ فقدان شرط حسن السمعة والسيرة اللازم لتوانى الوظائف والمناصب العامـة

$$
\text { أو النيابية }
$$

ـ تجميد أموال الإرهابي متى استخدمت في ممارسة نشاطه الإرهابي. وقد سبق أن تبنى المشرع الأمريكي مجموعة كبيرة من التدابير تفرض على أثر مالري

إدراج المنظمة دون اشتراط صدور حكم قضائي بذلك؛ منها: 


\section{- - تجميد أمو الها في البنوك والجهات المختلفة في البلاد(').}

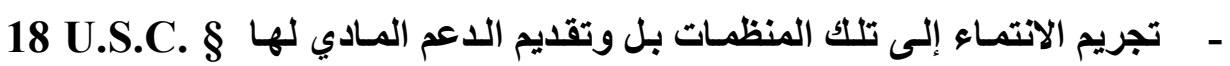

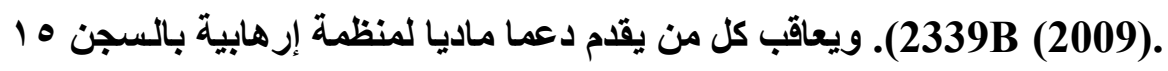

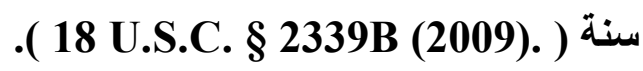

- إبعاد الأجاتب المتهمين بهذه الجرائم إذا لم تثبت إدانتهم("). وإذا ثبتت تلكك الإدانة فإن الإبعاد يكون بحكم قضائي. ويترتب على وصف المنظمة بأنها إرهابية عدة نتائج، منها ما يلي: - - تجميد أمو الها في البنوك والمصارف المالية

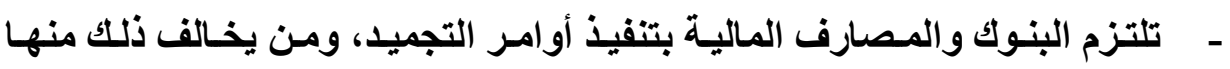

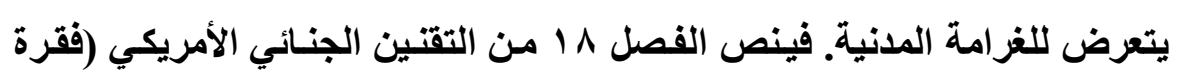

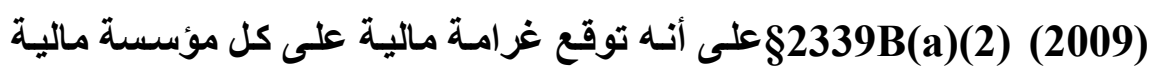

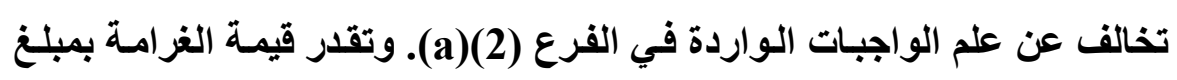

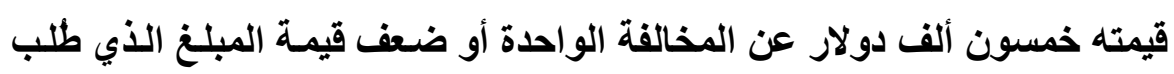
من المؤسسة أن تقوم بتجميده.

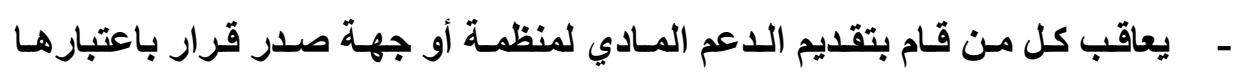

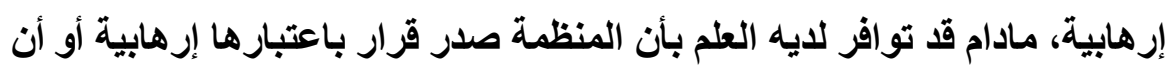

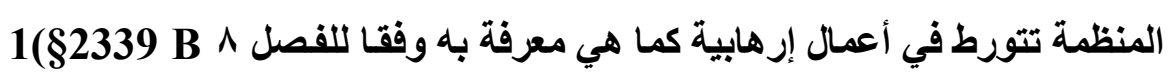
.(1996)

(1) MICAH Wyatt , DESIGNATING TERRORIST ORGANIZATIONS:DUE PROCESS OVERDUE, 39 Golden Gate U. L. Rev. 221 2008-2009: http://heinonline.org (2) 18 U.S.C. § 2339B (2009). 
- رفض دخول الأجنبي وطرده عند تواجده على الأراضي الأمريكية، حيث ينص

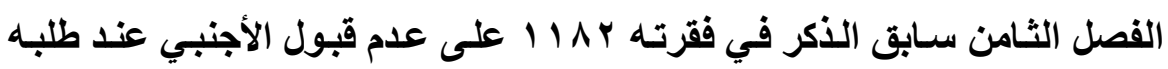

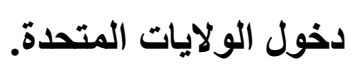
- يجوز حبس الأجنبي قبل إبعاده حتى تتنهي إجراءات الإبعاد. ويجوز أن تستند

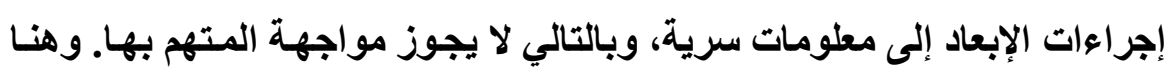
أيضا يبرز ثقل المصلحة القومية عن الحقوق الفردية. غير أن المشرع الأمريكي

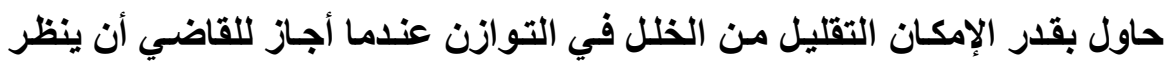

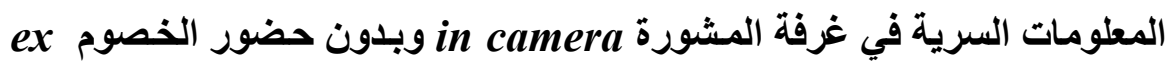

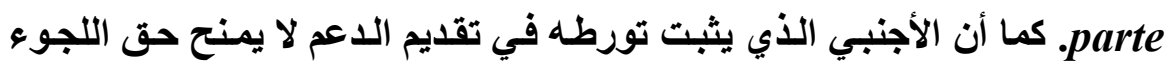

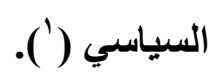

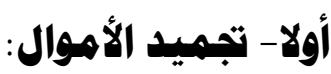

عرّقت المادة الأولى من القرار بقانون في شـأن تنظيم قوائم الكياتـات الإرهابية

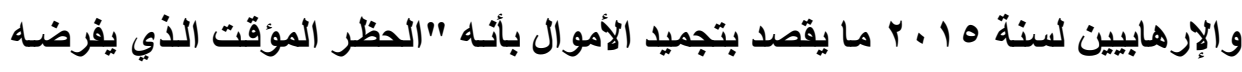

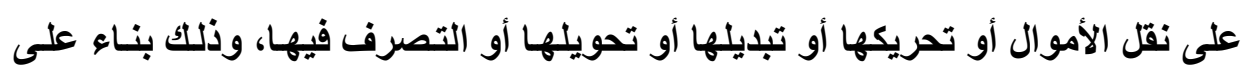
القرار الصادر وفقا لنص المادة (َّ) من هذا القانون". وواضح أن المراد هنـا هو تجميد الأموال وليس مصادرتها أو نزع ملكية تلكت

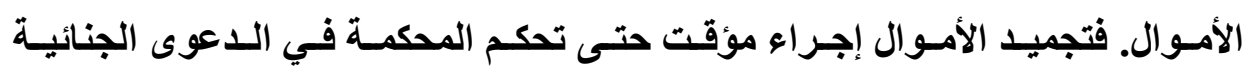
المرفوعة ضد التنظيم الإرهابي والإرهابيين المتهمين أمامها.

(1) 18 U.S.C. $§ 11115558$ (b)(2)(A)(v)(2009).

مجلتّ البحوث القانونيت والإقتصاديت 1 1 
لذا تنص المـادة ^ من قانون الكيانـات الإرهابية على أنهه "في الأحوال التي تقتضي فيها طبيعة الأموال المجمدة تعيين من يديرها، يجب أن يحدد قرار المحكمة من يدير هذه الأموال بعد أخذ رأى النيابة العامة. وعلى من يعين للإدارة أن يتسلم الأموال

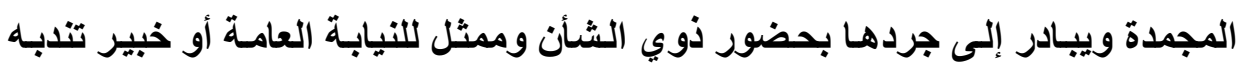
المحكمة. ويلتزم من يعين للإدارة بالمحافظة على الأموال وبحسن إدارتها، وردهـا مـع غلتهـا المقبوضـة طبقاً للأحكام المقررة في القـانون المـدني بشأن الوكالـة في أعمـال الإدارة والوديعة والحراسـة، وذلك على النحو الذي يصدر بتنظيمـه قرار مـن وزيـر

\section{تجميد الأهمال والحق في الالكية:}

على الرغم من أن إجراء تجميد الأموال يمس الحق في الملكية ويتعين احترام الحق في الدفاع في شكل إخطار تلك الجهات قبل القيام بـللك الإجراء وسماع أقوال

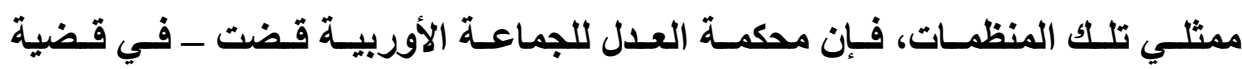
المجاهدين الإيرانيـة ضد فرنسـا - بأنسه يتعين التمييز بين حسالتين؛ الحالـة الأولى هو إصدار قرار بتجميد الأموال وهنـا لا يلزم إخطسار الجهة قبـل تجميد أموالها، لأن هذا الإجراء يستلزم السرعة والمفاجأة، انتظارا للقرار المحكمة النهائي بمصادرة أموالها

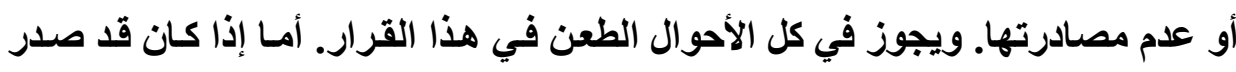
قرار بالتجميد قبل ذلك انتظارً للمحاكمة وانتهت المدة المقررة له، وتقوم السلطات بمد لهد هذا الإجراء، فإنها في تلك الحالة تلتزم بـاحترام مقتضيات الدعوى العادلة من إخطار

$$
\text { الجهة بمبررات التجميد ومد قرار التجميد( '). }
$$

(1) C. Demunck, Rejet du pourvoi de la France contre la radiation de la People's Mojahedin Organization of Iran de la liste des organizations terroristes, CJUE, gdech., 21 déc. 2011, France c. People's Mojahedin Organization of Iran, aff. C-27/09.

مجلت البحوث القانونيت والإقتصاديت 


\section{تجميد الرصيد في القانون الأهريكي:}

يلخل تجميد الأرصدة في البنوك الأمريكية ضمن التدابير الإداريـة التي يجوز للرئيس الأمريكي اتخاذها، الأمر الإداري الصادر من الرئيس الأمريكي الذي يخول

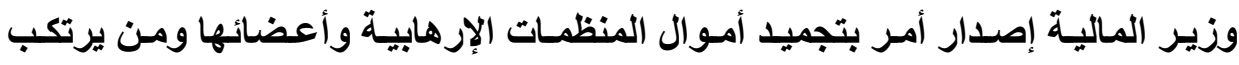
أعمالا إرهابية أو من يساعد من يقوم بذلك. ويحظر على المواطنين الأمريكيين أن يقوموا بعمل صفقات مع من تم تجميد حساباته المالية. كما أن الجهات التي تقوم بتلك الصفقات المخالفة ولو كانت جهات أجنبية يخضعون لنفس التدبير وهو تجميد أموالهم. وتصدر قرارات تجميد الأمسوال بقرارات رئاسية بمقتضى قـانون الطوارئ الاقتصادية الدولية (2001) 0- 50 UAC s 1701 ). وتخضع لهذا التدبير المنظمـات الإرهابية، كما في حالة حماس التي أصدر الرئيس الأمريكي كلينتون أمرا في سنة هو 9 ه باعتبارها منظمة إرهابية، وبالتالي خضعت لقرار التجميد.

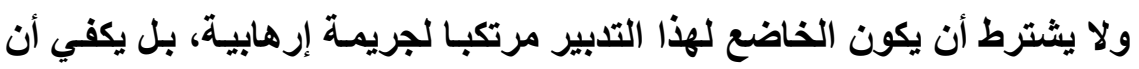
يكون له علاقة بتلك الجريمة associated with this offense أو يكون مشكلا

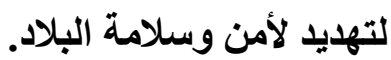

ويلتزم الأفراد و الشركات والمؤسسات المالية بعلدم عقد صفقات مـع الجهات التي تم تجميد أمو الها بخصوص الأموال المجمدة. كما أن المصارف المالية تلتزم بقرار التجميد، وتوقع غرامات مالية مدنية على تلك المصارف التي لا تلتزم بقرارات التجميد. ويقدم الدليل على العلاقة مـع الإرهاب بشكل سري وفي غرفة المشورة عند الطعن على القرار الصادر بالتجميا للأموال. 
ويجوز تقديم تظلم إلى وزير الخارجية بخصوص وضع منظمة معينة على قائمسة الإرهاب الأجنبي. ويقوم الوزير بنظر التظلم بعد مراجعة الأدلة السرية المقدمة ضد تلك

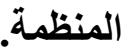
وقد قضت محكمة D.C. Circuit Court 206 بـأن القرارات الرئاسـية الصادرة بتجميد الحسابات هي من أدوات السياسة الجنائية المقبولة('). الترام الدول بتجميد أهوال المنظمات الإرهابية وفقا لاتفاقية سنة 1999 : تنبه المجتمع الدولي إلى ضرورة مقاومة التظظيمات الإرهابية منذ اتفاقية سنة 9 9 9 9 التي تضمنت نصا بتجميد أموال التظيمات الإرهابية والأفراد أيضا. غير أن ذلك النص لم يوضع موضع التفيذ حتى حصل هجوم الحادي عشر من سبتمبر في الولايـات المتحدة، عندما صدر قرار مجلس الأمن رقم I TVY بذلك التجميد. كما تم تجميد أموال دول راعية للإزهاب مثل ليبيا وإيران.

\section{ضمان الدعوى العادلة في حالة ضبط الأهوال:}

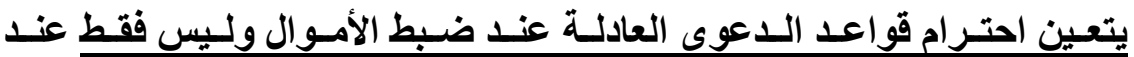

المحاكمـة. تطبيقاً للذلك قضت المحكمـة العليـا للولايـات المتحدة الأمريكيـة بـأن قواعد الاعوى العادلة تخاطب الجهات جميعها التي تتخذ إجراءات ماسـة بالحيـاة أو بالحريـة

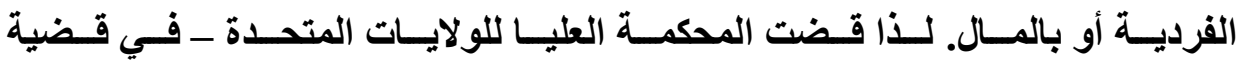
Dusenbery v. United States ضبط الأموال في قضايا المخدرات تمهيدا لمصادرتها من المحكمة، فإن عليها أن تخطر كل من له حقوق على هذا المال وأن تمكنه من تقديم أوجه دفاعه( ).

(1) http://news.findlaw.com/hdocs/docs/terrorism/hlylndfndvash8082op.pdf>.

(2) Dusenbery v. United States 534 U.S. 161 (2002). 


\section{ثانياً- طرد الأجنبي المشتبه بعضويته أو بعلاقته بتنظيم إرهابي:}

\section{حق الدولة في طرد الأجنبي المشتبه في علاقته بتنظيم إرهابي:}

من ينتمي إلى تنظيم إرهابي لا يتمتع بالحمايـة التي تقررهـا اتفاقيـة جنيف

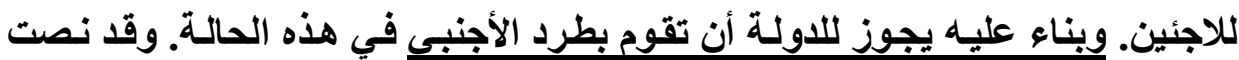

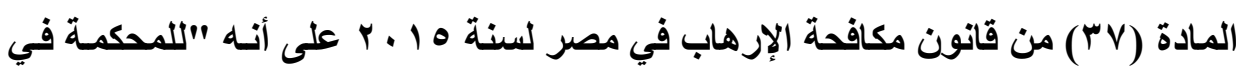
أيـة جريمـة إرهابيـة فضلا عن الحكم بالعقوبـة المقررة أن تقضي بتدبير أو أكثر من فن

$$
\text { التدابير الآتية: (1) إبعاد الأجنبي عن البلاد....". }
$$

وقد انتهت إلى ذلك أيضاً لجنة اللاجئين وأيدها القضاء الإداري الفرنسي في الإدي

أحكام لها('). وبناء عليه يكفي يثبت توافر تلك العضوية. وقد وضع القضاء معيارين لرفض لجوء الأجنب؛ يتمثل المعيار الأول في أن ثبت بمقتضى قرائن قوية أنه ارتكب

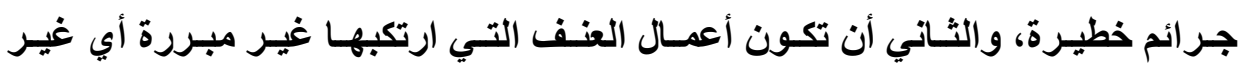
مشروعة بـالنظر إلى غايتها("). وقد اعتبرت لجنـة اللاجئين مؤيدة في ذلكت بأحكام القضاء بأن عضوية تنظيم إرهابي يقوم بأعمال عنف ضد المدنيين يكفي لتوافر هذين المعيارين ومن الواضح أن هذا الإجراء يخص الأجاتب ولا يسري على المواطنين الذين لا يجوز للاولة طردهم. وقد تقرر ذلك في قضية تطقت بثخص أجنبي لله علاقة بتنظيم

(1) Francis Donnat, Un dirigeant terroriste ne peut pas bénéficier de la convention de Genève, JDA 2006 p. 269

(2) Silva Handari Dewage (CE 28 février 2001, req. $\mathrm{n}^{\circ}$ 195356). 
"حزب العمال الكردستاني" PKK الذي صدر قرار من المجلس الأوربي وحكم من المحكمة الأوربية لحقوق الإنسان باعتباره تنظيما إرهابيا(').

فـلا يجوز لمـن تـوافر في حقـه أسباب جديـة لارتكابـه جرائم عنيفـة بالمخالفة

لميثاق الأمم المتحدة أن يستفيل من أحكام اتفاقيـة جنيف التي أعدتها الأمم المتحدة، بهذا قضى مجلس الدولة الفرنسي(؟). غير أنسه يلزم أن يثبت ذلك للدى اللجنة تحت رقابة القضاء. وسواء كاتت تلك الأفعال تامة أو كاتت شروعا في أعمـال عنف(َ) . ولا يشترط لثبوت مشاركة الطـاعن في أعمـال العنف أو الشروع فيـه سبق صدور حكم بالإدانـة مـن القضاء الوطني أو الأجنبي ولكن يكفي أن توجــ أسباب قويـة للاعتقـاد بمساهمته في تلك الأفعال. وعلى أيـة حسال لا يكفي توافر الاشتباه أو مجرد التحريـات الالة على ذلك( ).

وقد استخلصت اللجنـة موئدة بـلتك مـن أحكـام مجلس الدولـة عضوية طالب اللجوء مـن أنـه كـان الرجل الثاني في حزب العمـال الكردستاني وأنـهـ كـان يساهم في القرارات التي يتخذها الحزب وأنه كان يتفاوض باسم هذا الحزب (م).

(1) Cour européenne des droits de l'homme (25 novembre 1997, Mehdi Zana c/ Turquie)

(2) CE 31 juillet 1992, M. Duvalier, Lebon tables p. 985; Combarnous,La convention de Genève 50 ans après : bilan et perspectives, Publication de l'institut international des droits de l'homme, Bruylant, 2001),

(3) Silva Handari Dewage (CE 28 février 2001, req. $n^{\circ}$ 195356)

(4) CE 25 mars 1998, MmeMahboub, Lebon tables p. 961, www.dalloz.fr/documentation/Document?id

(5 ) Francis Donnat, Un dirigeant terroriste, ibid, p. 269 


\section{جواز الحبس الإداري تمهيدا للطرد:}

إذا قررت السلطات طرد الأجنبي فإنه يجوز حبسه حتى تتم ترتيبات طرده من

البلاد. من ذلك أن القانون الكندي يجيز أن يتم حبس الأجنبي المتهم بعلاقات مي تنظيم

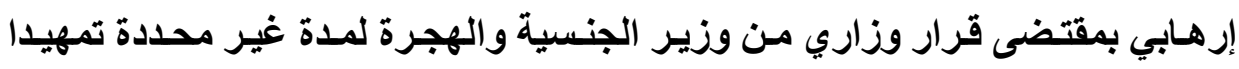

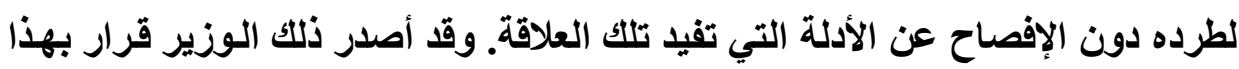
المعنى في حق Adil Charkaoui المغربي الجنسية في مايو سنة ب . . ب و المقيم

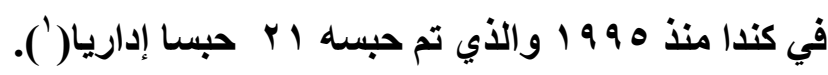

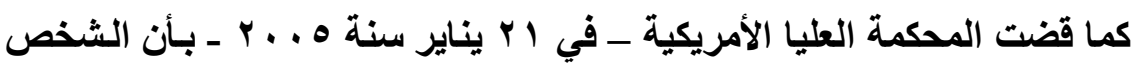
الأجنبي له حق في الحماية من الحبس غير محدد المدة، وأنها يجب ألا يتعدى المدة

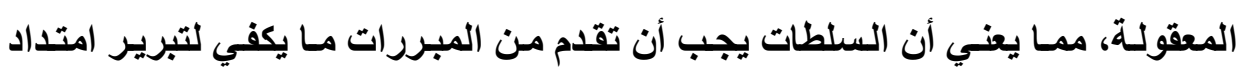

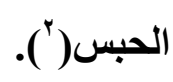

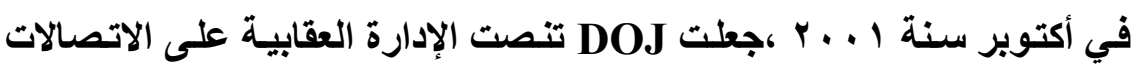

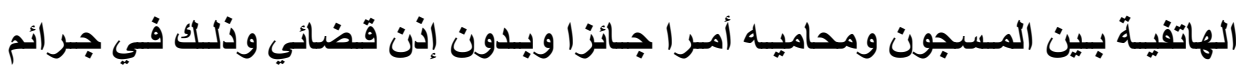

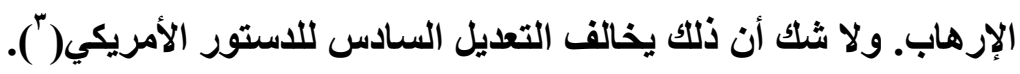

(1) Hélène Dumont, Actualités du droit pénal canadien, RSC 2008 p. 221

(2) JOHN A.E. VERVAELE, THE ANTI-TERRORIST LEGISLATION IN THE US: CRIMINAL LAW FOR THE ENEMIES, 1 Inter-Am. \& Eur. Hum. Rts. J. 52008

(3) JOHN A.E. VERVAELE, 
هل يجوز الاستناد إلى تحريـات سرية تقوم بها إدارة المخـابرات كسند لطرد

الأجنبـي المشتبه بعلاقته بمنظمـات إرهابيـة؟ على هذا التساؤل أجب مجلس الدولـة الفرنسي بقرار صادر في ؛ أكتوبر سنة ع . . ب بجواز ذلك(').

وقد أجاز مجلس الدولة الفرنسي الاستناد إلى تحريات المخابرات وهي معلومات

سرية كسند لطرد الأجنبي المتهم بجرائم خطيرة مثل العلاقة مع تنظيمات إرهابية. ذلك Ministre de l'Intérieur, de la ما قضى بـه مجلس الدولة الفرنسي في قضية سنتة Sécurité intérieure et des Libertés locales c/ M. Bouziane

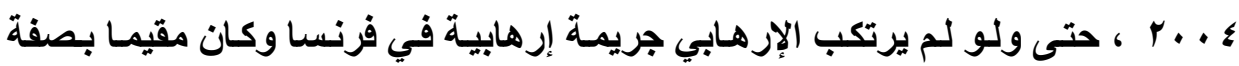
دائمة في البلاد ويرتبط بالبلاد بأواصر عائلية قوية (فهو أب لأطفال فرنسيين)،('). وقد صدر هذا القرار تطبيقا للقانون الفرنسي الذي ينص على طرد الأجنبي إذا كـان يـعو إلى التمييز أو العنف أو الكراهيـة(ب). بهـذا قضى مجلس الدولـة مؤيـا قرار وزيـر الداخلية بطرد أحد أئمة المساجد الذي كان له علاقة بتنظيمات إرهابية أفغانية ويمنية

$$
\text { وشيشانية، ولم يقم عليه دليل سوى تحريات المخابرات العامة()؛. }
$$

(1) Conseil d'Etat, 04-10-2004, Quand les renseignements généraux convainquent le Conseil d'Etat, AJDA 2004 p. 1846

(2) Conseil d'Etat, 4 octobre 2004, Ministre de l'Intérieur, de la Sécurité intérieure et des Libertés locales c/M. Bouziane (req. $\mathrm{n}^{\circ}$ 266948)

(3) la loi du 26 juillet 2004 (loi $n^{\circ}$ 2004-736, JO 28 juillet 2004) modifie l'article 26 de l'ordonnance du 2 novembre 1945

(4) Olivier Lecucq, Les notes des renseignements généraux peuvent fonder une decision d'expulsion, AJDA 2005 p. 98. 
كمـا أجاز مجلس الدولـة الفرنسي طرد الأجنبي المشتبه في علاقته بمنظمسات إرهابية استنادا إلى تحريات المخابرات وهي تحريات سرية، ولا يشترط تقديم دليل على اشتراكه في تلك التنظيمات أو اشتراكه في ارتكاب جرائم إرهابية لكي يسبب قرار طرده

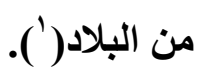

\section{الضمانات القانونية في حالة صدور قرار الطرد:}

أصبح طرد الأجنبى محاطا بضمانات تكفل عدالة الإجراء نظر آ لخطورتهه وأنـه

يؤثر على مستقبل الشخص المطرود الذي قد يكون طالب علم أوعاملا في شركة أو مقيما مع أسرته أو يلاقي اضطهادا في بلده الأصلي. لذا يوفر القانون المقارن ضمانات لتحقيق ذلك. من ذلك أن القانون الفرنسي يتضمن ضماناتٍٍ قانونية لمن صدر ضده قرار بالطرد. من تلك الضمانات الحق في الطعن. للأجنبي أن يطعن في قرار طرده في

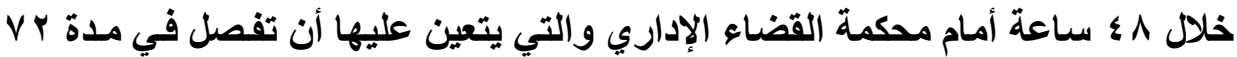
ساعة. ولا يجوز تنفيذ قرار الطرد قبل مرور تلكك المهلة. وعلى أية حال لو استمرت القضية متذاولـة أمسام المحكمة الإداريـة لمدة تزيــ عن ذلك، فإنـه لا يجوز تنفيذ قرار الطرد قبل ذلك. وإذا صدر حكم من المحكمة الإداريـة بصحة قرار الطرد، فِإن المحكوم عليه أن يطعن بالاستئناف، غير أن قرار محكمة القرار الإداري ينفذ أي يتم تنفيذ قرار محكمة أول درجـة وهو قرار الطرد وفقـا لمـا هو مقرر في القواعد العامـة في أحكام

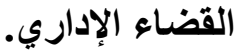

(1) Arrêt rendu par Conseil d'Etat, sect. cont., 04-10-2004, n $^{\circ} 266948$, Expulsion d'un imam soupçonné de liens avec des mouvements terrorists, Recueil Dalloz 2004 p. 2763 
وقد طعن أمام المحكمة الأوربية لحقوق الإنسان بمخالفة ذلك للحق في التقاضي على درجتين، باعتبار أن قرار محكمة القرار الإداري (أول درجة) يتم تنفيذه معجلا دون أن يكون للطعن أثر واقف، مما يعرض الطاعن الذي صدر له قرار بالطرد لخطر لا يمكن تداركه. قضت المحكمة بأن الأجنبي الطاعن يتمتع بالحق في التقاضسي مـادام أن قرار طرده كـان جـائزا الطعن فيسه ومــادام أن هذا الطعن كـان لـه أثنر واقف، أمسا أن استئناف حكم محكمة القضاء الإداري ليس لله أثر واقف، فإنه لا يحرم الطاعن من حقـه في الطعن، وأنه يعد امتثالا لمـا هو مقرر كقاعدة عامـة عند الطعن في أحكام محكمة القضاء الإداري('). وتقضي قواعد العدالـة الإجرائية وفقـا لرأي المحكمـة العليـا الكنديـة بضرورة

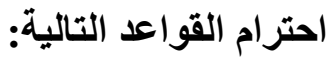

$$
\text { 1- الحق في العرض على قاض أو حاكم قضائي، }
$$

r- القاضي أو الحاكم القضائي يجب أن يكون مستقلا ومحايدا، r- البت في الطعن في قرار الحبس يجب أن يكون مستثلا إلى القانون والواقع، يجب أن تسمح إجراعات الطعن بمعرفة الطاعن بالأدلة المقدمة ضده وأن يكون مـن حقـه الـرد عليها. وقــ أثسارت المحكمة إلى أن النمـوذج الإنجليزي يقوم بـالتوفيق بـين اعتبـارات المحافظة على سـرية المعلومـات واعتبـارات العدالـة

(1) COUR EUROPEENNE DES DROITS DE L'HOMME, Affaire H. R. c/ France (5ème section), arrêt du 22 septembre 2011 


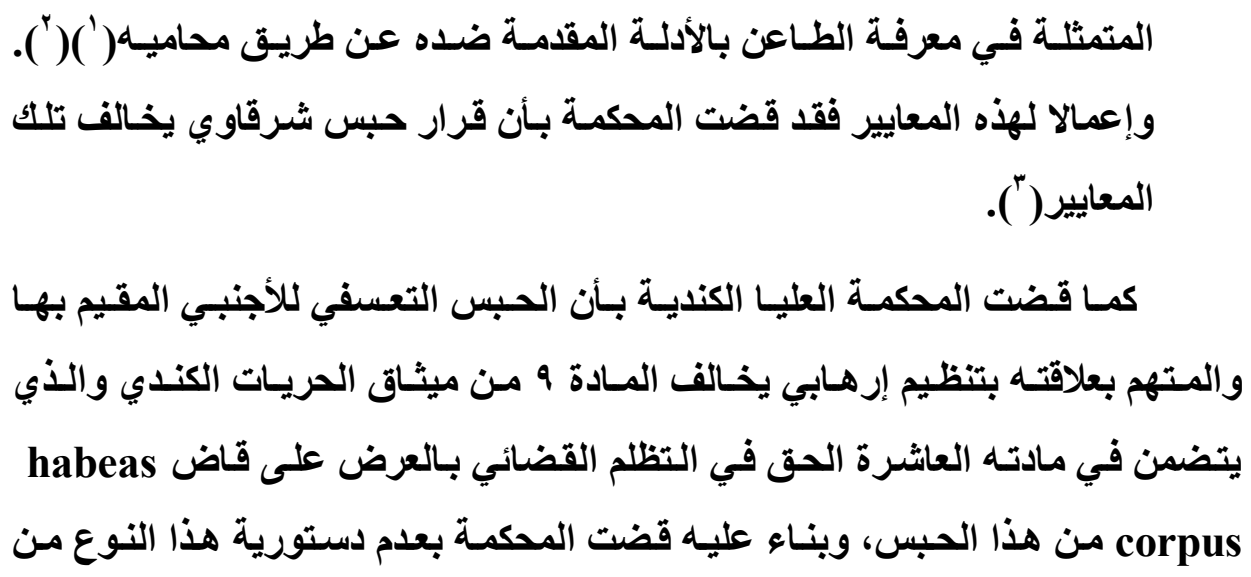

(1) Anti-terrorism, Crime and Security Act (Royaume-Uni), 2001 c. 24, Prevention of Terrorism Act (Royaume-Uni), 2005 c. 2. Pour une discussion de la nouvelle législation antiterrorist anglaise dans une perspective canadienne, V. Rhonda Powell, Human Rights, Derogation and Anti-বTerrorist Detention, 2006, 69 Sask. L. Rev. 79, 93-97.

(2) La Cour suprême note que le Royaume-Uni fait appel à un système de representation spéciales pour protéger les intérêts de la personne détenue tout en préservant la confidentialité des renseignements qui doivent demeurer secrets. $V$. un commentaire de la loi anglaise dans $K$. S. Campbell, Recent Supreme Court of Canada Decision: Charkaoui v. Minister of Citizenship and Immigration, (2007) SCC 9, http://www.shk.ca/docs/CharkaouiMinsterCitizenshipandImmigration.p df, p. 7.

(3) Supreme Court of Canada decision, Charkaoui v. Minister of Citizenship and Immigration (2007 SCC 9,: http://shk.ca/docs/CharkaouiMinisterCitizenshipandImmigration.pdf.p. 7 
ولم تستبعد المحكمة الكندية في حكمها الحبس غير المحدد للإرهابي انتظـارا لإلغاء إقامته وطرده من البلاد، ولكنها تدين عدم وجود وسيلة قانونية لإعادة النظر في ذلك الحبس حالة بحالة) (').

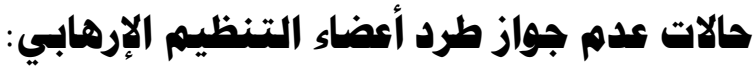
إذا كان من المقرر أنه عند وجود أجنبي متهم بانتمائه إلى تنظيم إرهابي معين، فإن يجوز تسليمه إلى بلده حيث يواجه تلكك التهمة. ومع ذلك فإن هنالك قيوداً قد تحول دون تنفيذ ذلك الطرد. من أهم ذلك أن يكون الشخص المهدد بـالطرد مهدداً في بلده بالتعذيب أو بعقوبة أو معاملة غير إنساتية. تطبيقا لذلك قضت المحكمة الكندية العليا في بr فبرايـة سنة V . . . ب بأن قرار حبس المتهم غير الوطني لعلاقته بتنظيم إرهابي لاعتبار ات الأمن يخالف مبادئ العدالة التي تنص عليها المادة(V) من ميثاق حقوق الإنسان الكندية والتي تنص على أن "لكل إنسان الحق في الحياة والحرية والأمن في شخصه، فلا يمكن المساس بتلك الحقوق إلاّ وفقا للقانون"(")، إذا كان هناك احتمال قوي أن الثخص سوف يتعرض للتعذيب عند طرده وتسليمه إلى بـلاده. وقد سبق أن قضت المحكمة العليـا الكنديـة بـذلك في حكم Suresh

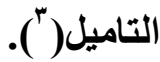

(1) Supreme Court of Canada decision, Charkaoui v. Minister of Citizenship and Immigration, id.

(2) Charkaoui c/ Minister de la Citoyenneté et de l'Immigration et al. (2007) 1 RCS 350.

(3) Suresh c/ Canada (ministre de la Citoyenneté et de l'Immigration), [2002] 1 RCS 3. 
وتحمي الاتفاقية الأوربية لحقوق الإنسان الأجنبي الذي صدر ضده أمر بطرده

من بلـل أجنبي إلى بلـده الأصلـي لـو كـان من المحتمل أن يتعرض هذا الشخص إلى الثى التعذيب أو المعاملة القاسية. وتمتد هذه الحمايـة إلى الأجنبي ولو كـان متهمـا بجريمـة من جرائم الإرهاب كمـا لو كان على علاقة بتظظيم إرهابي. عندئـذ لا يجوز تنفيذ أمر طرده من البلاد. هذا ما اطرد قضاء المحكمة الأوربية لحقوق الإنسان('). وقد أكلد المحكمة الأوربية لحقوق الإنسان هذا القضاء عندما قضت بـأن هنـاك قيدا يتمثل في عدم تعريض المتهم إلى التعذيب أو المعاملة القاسية حيث تحرم المسادة

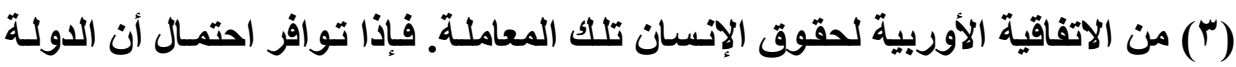
المستقبلة للمتهم بعضوية تنظيم إرهابي تمسارس السلطات فيها التعذيب في مواجهة المتهمين بتلك الجرائم، أو كان القانون يقرر عقوبة غير متناسبة كمـا لو كانت عقوبـة الإعدام أو الحبس المؤبـد أو كـان يخضع لمحسكم عسكرية لا تكفل احترام الحق في دعوى عادلة، فإنه على الدولة التي يتواجد فيها المتهم بعضويته لتنظيم الإرهابي ألا

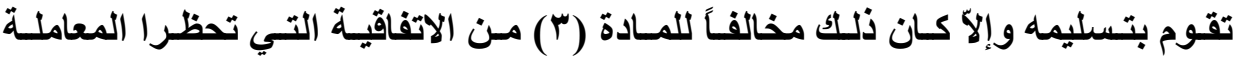
القاسية. هذه المبادئ قررتها المحكمة الأوربية لحقوق الإنسان في العديد من أحكامها

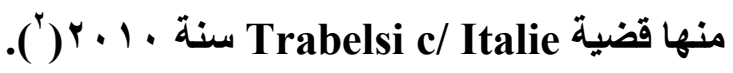

كمـا قضت المحكمة ذاتها في قضية H. R.c/ France,Arrêt du سنة I I ب بأنه وإن كان المدعى متهما في جريمة إرهابية في بلا ما وكان يقيم في فرنسا،

(1) Caroline Fleuriot, CEDH, 30 mai 2013, Rafaa c. France, req. $n^{\circ}$ 25393/10, Expulsion d'un étranger lié à des organisations terroristes et risque de torture, Dalloz actualité 13 juin 2013

(2) COUR EUROPEENNE DES DROITS DE L'HOMME, (2ème section) Arrêt du 13 avril 2010 , Affaire Trabelsi c/ Italie , ${ }^{\circ}$ 50163/08 
فإن تلك الدولة من حقها أن تأمر بطرده من البلاد حتى وإن كان متهمـا بارتكاب جرائم أخرى على الأراضي الفرنسية ليس من بينها جريمة من جرائم الإرهاب. ومع ذلكك فإن المحكمة قيدت حق فرنسا في طرد المدعي بأن لا يعرضه ذلك الطرد إلى بلاده إلى خطر التعرض لمعاملة قاسية أو غير إنسانية كأن يتعرض للتعذيب أو لمحاكمـات غير عادلة من ضمن ذلك أن يتعرض للحكم عليه باعتباره عضوا في منظمـة إرهابية إلى عقوبـة السجن المؤبد. هذا ما قضت به المحكمة عندما أصدرت فرنسا قرارا بطرد المدعي وهو جزائري إلى بلاده الجزائر، وكان محكومـا عليه غيابيا بالسجن المؤبـ لأنسه عضو في تنظيم إرهابي('). هذا سبق أن قضت تللك المحكمة بذلك(بَ). رفض طلب الابموي بسبب الانتمهاء إلى هنظمة إرهابية:

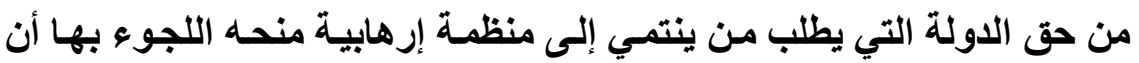
ترفض طلبه. بهذا قضى مجلس الدولة الفرنسي استنادا إلى أن اتفاقية جنيف المبرمـة

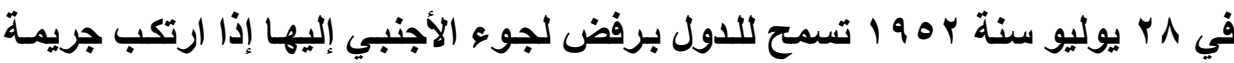
خطيرة في خارج تلك الدولة. فباذا كان طالب اللجوء يتولى مركزا قياديا في "حزب

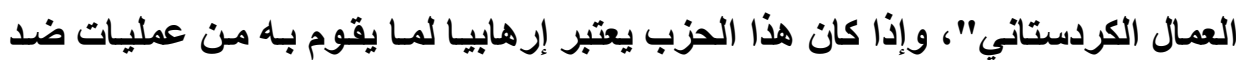
المـنيين سـواء داخل تركيـا أو خارجها، فـإن رفض منــه اللجوع في فرنسـا يكون متوافقا مع القانون، بهذا قضى مجلس الدولة الفرنسي(").

(1) COUR EUROPEENNE DES DROITS DE L'HOMME, (5ème section), Affaire H. R.c/ France, Arrêt du 22 septembre 2011

(2) Cour Européenne des Droits de L'Homme, arrêts Saadi c. Italie ([GC], $n^{\circ} 37201 / 06, \S \S 124-133$, CEDH 2008-...) et Daoudi c. France (n 19576/08, § 64, 3 décembre 2009).

(3) Arrêt rendu par Conseil d'Etat, 10ème et 9ème sous-sections reunites, Recueil Lebon - Recueil des décisions du conseil d'Etat 2005 


\section{ثالثا- حظر هغادرة الشباب لأراضي الدولة:}

من مظاهر ذاتيـة المعاملـة الوقائية للإرهـابيين مـا تقرره كثير من التشريعات المقارنة من الحرمان من سفر الأثخاص المشتبه في ولانهم للتنظيمات الإرهابية عن طريق سحب جواز سفرهم ووضعهم على قائمة المنوعين من السفر.

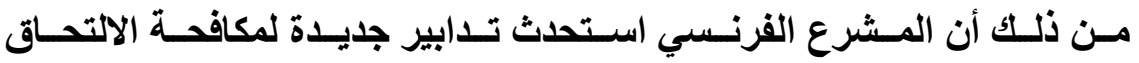

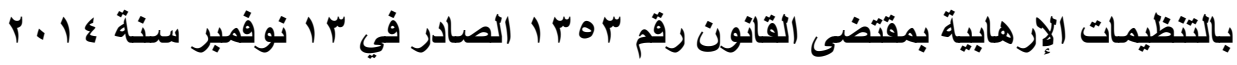
(مادة ())، وذلك للوقاية من خطر التحاق الثباب بالتظيمات الإرهابية كنوع من الوقاية

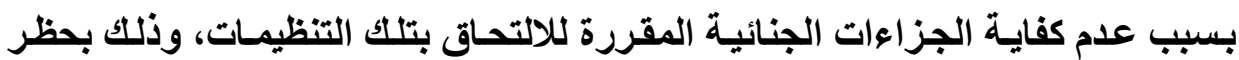
مغادرة الأراضي الفرنسية للوطنيين الذين يُشتبه في أن سفرهم إلى الخارج هو بغرض الالتحاق بالتنظيمات الإرهابية مثل تنظيم "داعش". وبالمثل فإن المشرع أدخل تدبيرا آخر هو حظر دخول الأراضي الفرنسية لبعض من يشتبه في أن لهم علاقة بالتنظيمـات

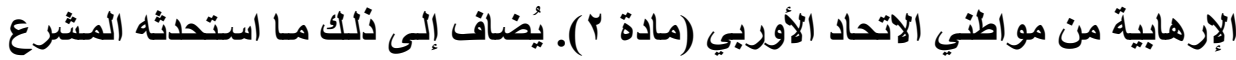

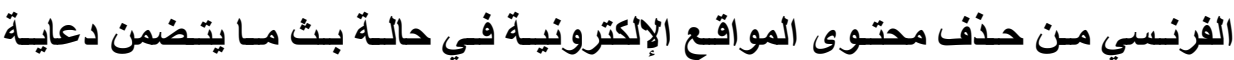

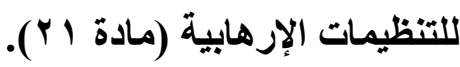
بالإضافة إلى تلك التابير استحدث المشرع الفرنسي في القانون الصادر سنة

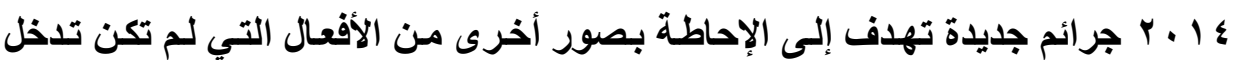
تحت التجريم. من ذلك تجريم التحريض على الإرهاب أو استحسانه وتأييده والقيام بأفعال تحضيرية لارتكاب أفعال إرهابية. 


\section{رابعاً - همارسة الدول لهق الدفاع الشرعي ضد التنظيسات الإرهابية:}

كان للهجمـات التي قامت بها القاعدة ضـد الولايـات المتحدة أثرهـا في إثـارة

النقاش حول مدى قانونية استعمال قوات التحالف الاولي لحق الدفاع الشرعي ضد هذا

التنظيم وضد تنظيم طالبان في أفغانستان.

للإجابة على هذا التساؤل يتعين أولا أن نحدد مـا إذا كانوا إرهابيين أو مقاتلين

في الحرب. في ذلك يمكن تعريف الحرب بأنها مواجهة متوالية وذات جسامة كبيرة بين

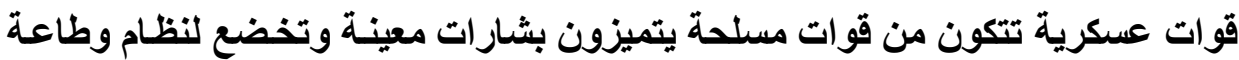
تحت رئاسة قائد يأتمرون بأمره('). ومع ذلك استخدمت قوى التحالف الدولية حقى الدفاع الثرعي في محاربة الإرهابيين والدولة التي تأويهم وتحميهم وهي أفغانستان. ومن المستقر عليه وفقا للقانون الدولي أنه يجوز استخدام الدفاع الثرعي وفقا للمسادة (10) من ميثاق الأمم المتحدة بشرطين؛ الثرط الأول وهو شرط اللزوم والثرط الثاني وهو شرط التتاسب("). ومع ذلك فقد ثارت شكوك حول توافر شرط اللزوم باعتبار أنهـ كان يتعين توافر خطر حال ولم ينته، كما ثارت شكوك حول تناسب مع قامت بـ بـ قوات التحالف مع الخطر القائم.

(1) Justin N. B. Frank and Javaid Rehman, Assessing the Legality of the Attacks by the International Coalition against Terrorism against AlQaeda and the Taliban in Afghanistan: An Inquiry into the Self-Defence Argument under Article 51 of the UN Charter 67 J. Crim. L.( le Journal of Criminal Law) 415 2003: http://heinonline.org.

(2) Justin N. B. Frank and Javaid Rehman, id 
أ.د/ شيماء عبد الغنى محمد عطا الله

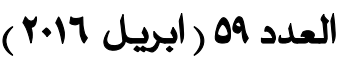

مجلتً البحوث القانونيتّ والإقتصاديت ع ؛ 


\section{المبحث الثالث}

\section{النظام الإجرائي الخاص بمكافحة الإرهاب}

أصبح الإجراءات الجنائية في مكافحة الإرهاب تتميز بأحكام يخرج بها المشرع

عن النظام العام الإجرائي في مكافـة الإجرام بوجهه عـام. فمثثلا أصبح حجز الشرطة

يصل إلى 99 ساعة وأصبحت مدد الحبس الاحتياطي يسمح بها أن تمتـد إلى أبعد عما هو بالنسبة للجرائم التقليدية.

التوسع في اختصاص القضاء الفرنسي بنظر جرائم التنظيسهات الإرهابية:

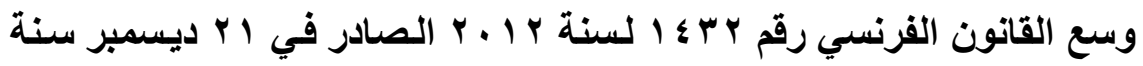

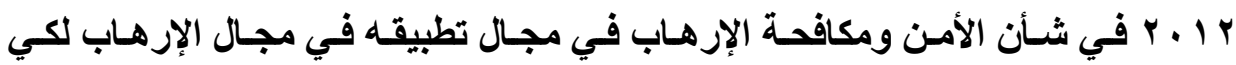
يسري على جرائم الإرهاب التي تحدث في الخارج لو كان الفاعل له الجنسية الفرنسية أو ممن يقيم بصفة معتـادة على الإقليم الفرنسي. وبالتالي تختص المحاكم الفرنسية بنظر تلك الجرائم.

فقد لوحظ أن عددا من الشباب الفرنسي يسافرون إلى بلا أخرى حيث يتدربون مع تنظيمات إرهابية على أعمال قتالية ويقومون بأعمال إرهابية مع تلك التظيمات. لذاب لذابل عمد المشرع الفرنسي إلى التوسع في تطبيق القانون الفرنسي الذي يعاقب على صورة

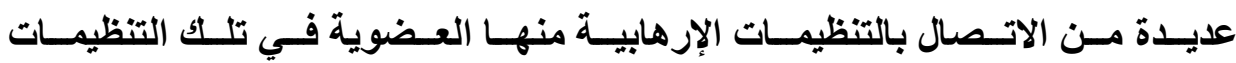

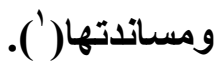

(1) Julie Alix , Fallait-il étendre la compétence des jurisdictions pénales en matière terroriste ?, (à propos de l'article 2 de la loi $n^{\circ}$ 2012-1432 du 21 décembre 2012 relative à la sécurité et à la lutte contre le terrorisme), Recueil Dalloz 2013 p. 518. 
و هنا فإن المشرع الفرنسي لم يصل إلى حد اعتناق مبدأ العالمية كما هي الحسال

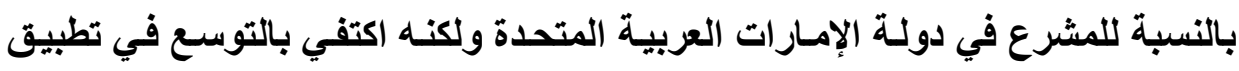
مبدأ الثخصية الإيجابية بعد إجراء تعديلات مهمة عليه من شـأنها أن توسع في مجال تطبيقه. - ت ن من مظاهر التوسع في تطبيق مبأ الثخصية الإيجابية في مجال جرائم الإرهاب

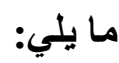
- يسري القانون الفرنسي وتختص المحاكم الفرنسية بمحاكمة المتهم في جرائم إرهابية ولو كان الفاعل مقيما بصفة دائمة - لا يشترط عودة المتهم الفرنسي أو المقيم بصفة معتادة في فرنسا إلى البلاد

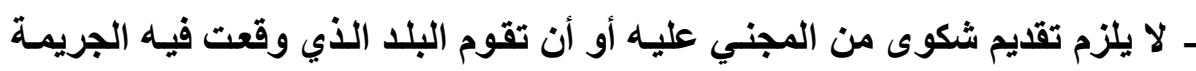

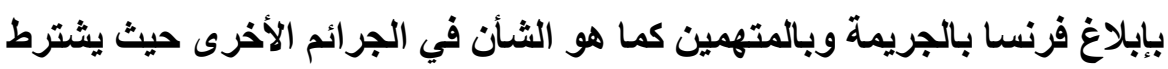
القانون الفرنسي ذلك لتطبق مبدأ الثخصية الإيجابية ـ لا يشترط أن يكون الفعل معاقبا عليه وفقا لقانون البلد الذي وقعت فيه أعمال الإرهاب، ذلك أن سلطات تلك البلا قد تكون متورطة في الإرهاب أو متسامحة فيه. يُضاف إلى ذلك أن المشرع الفرنسي يتوسع أصلا في تطبيق مبلأ الإقليمية لكي

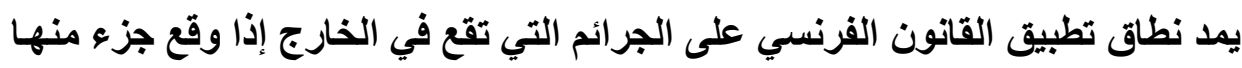
على الإقليم الفرنسي، وليس هذا فحسب ولكن إذا كانت هناك علاقة بين الإقليم الفرنسي

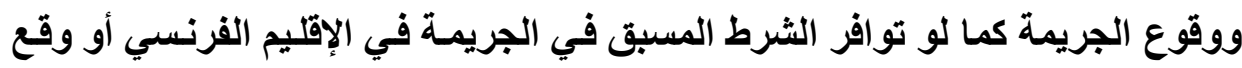

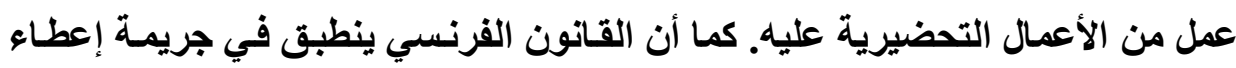


شيكك بـون رصيا لو وقع فعل الإعطـاء في الخـارج وكـان الشيك مسحوبا على بنـك

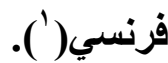

\section{جهاز هماكمة الاقاتلين الأجانب أهمام المهالس العسكرية الأهمريكية:}

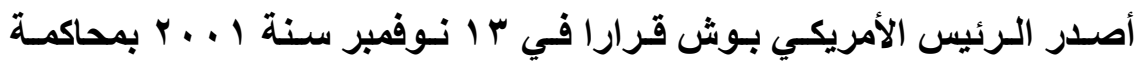

الإرهابيين في حوادث تفجير سفارات الولايـات المتحدة في كينيا وتنزانيا والتي راح ضحيتها . . . شخصا. وقد أصدر الرئيس الأمريكي هذا الأمر باعتباره رئيسا أعلى للقوات المسلحة بمحاكمة المتهمين بمخالفة قوانين الحرب وفقا للمـادة الأولى والثانيـة

$$
\text { من الاستور الأمريكي( (). }
$$

وقد أضفت المحكمة العليـا للولايـات المتحدة الأمريكية الشرعية على قرارات

الرئيس الأمريكي في قضية Johnson v. Eisentrager بخصوص إحالة المتهمين بجرائم إرهابية ضد الولايات المتحدة الأمريكية في خارج البلاد إلى المجالس العسكرية على سند من أن الاستور الأمريكي لا يحمي المقاتلين الأجاتب الذين يـخلون في عداء مع الولايات المتحدة) (ب).

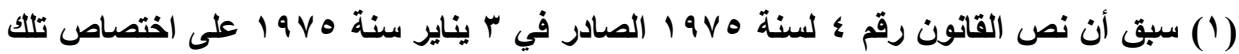

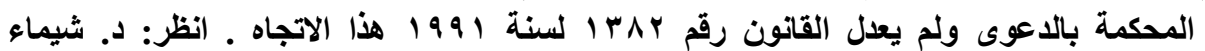

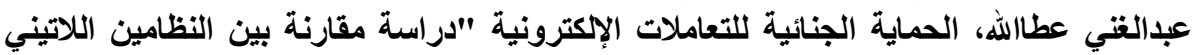

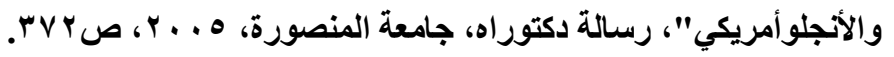

"Sans préjudice de l'application des dispositions des articles 43,52 et 382 du code de la procédure pénale, est compétent pour la recherche, la poursuite, l'instruction et le jugement des infractions prévues par les articles 66 et 69 , le tribunal où le chèque est payable“"

(2) JOHN A.E. VERVAELE, id , p. 40

(3) Johnson v. Eisentrager, 339 US 763 (1950).

مجلة البحوث القانونيتّ والإقتصاديتة 
مؤدى ذلك أن هؤلاء المقاتلين لا يرتكبون جرائم عادية وبالتالي لا يسري عليهم القانون الجنائي سواء من الناحية الموضوعية أو من الناحية الإجرائية. فلا يستفيدون من ضمانات حقوق الإنسان المقررة في الاستور الأمريكي. فلا يشترط مثتلا أن يتم تحديد تهمة معينة وتوجيهها إليهم، كما لا يشترط عرضهه على قاض لتجديد حبسهر. بل يسري عليه قواعد القانون الدولي المتعلقة بالحرب. وقد كاتت هذه المعالجة محلا للنقد، ذلك أن الإرهاب الدولي يختلف عن الحرب، كما أن قواعد القانون الدولي الإنساني ـ ومنها اتفاقيات جنيف ـ تنطبق في حالة الحرب

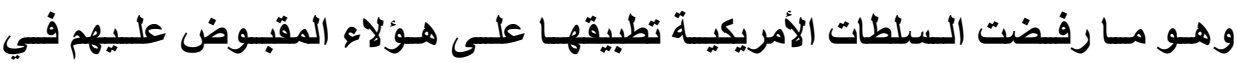
جوانتينـاموا Guantanamo الذين لم تعتبرهم السلطات الأمريكيـة أسرى حرب(' ). unlawful على خـلاف ذلـــ اعتبـرتهم تلــك السلطات مقــاتلين غيـر شـرعيين . combatants

وقد ترتب على فكرة المقاتل غير المشروع أن تم حبسهم مدة غير محددة كما آل الاختصاص بمحاكمتهم إلى مجالس عسكرية. وقد طعن أمسام المحكمة العليـا للولايـات المتحدة الأمريكيـة في حرمساتهم مـن ضـمانة المحاكمـة العادلـة. وقضت المحكمـة بـأن الأوامـر العسكرية التـي يختص رئسيس الدولـة بإصـارها وإن كانـت صـيحة، إلاً أن أسساسيات المحاكمة العادلة هي أن يتمكن المحبوس من الطعن في قرار اعتباره مقـاتلا

(1) G. Roma, "Interesting Times for International Humanitarian Law: challenges from the 'War on Terror"', 27 Fletcher Forum of World Affairs (2003), p. 55; L.M. Ivey, "Comment: Ready, aim, fire? The President's executive order authorizing detention, treatment, and trial of certain non-citizens in the war against terrorism is a powerful weapon, but should it be upheld?", 33 Cumberland Law Review (2002-2003), p. 107. 
غير شرعي وأن يطعن في قرار حبسه، حتى ولو كان ذلك أمام محكمة عسكرية، وذلك مع ضمان الحق في الاستعانة بمحام للقيام بذلك.

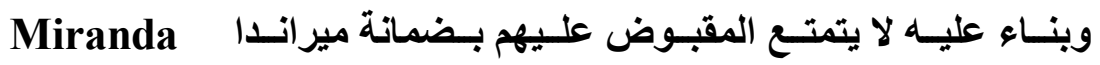
(')warning ولا ضمانة الهابيس كوربس Hapeas Corpus بالعرض على قاض لإصدار أمر الحبس والتظلم أمامـه من أمر الحبس وتجديده من جانب قاض. كمـا لا يتمتعون بـالحق في محاكمـة تجري بمحلفين. ومن الواضـح أن المجـالس العسكرية لا يتوافر فيه ضمانة القاضـي الطبيعي الذي يتمتع بالاستقلال والحيدة. كمـا لا يتمتعون بالمحاكمة العلنية التي تعد من ضمانات المحاكمة العادلة. كما لا يتوافر الحق في الدفاع بكامل جوانبه؛ فلا يطلع المدافع على شهادة شهود الإثبات، كما ليس للمدافع أن يتصل بالصحافة إلاً بعد الحصول على إذن وزارة الدفاع. وقد عرض أمر المقاتلين غير الشرعيين على القضاء الأمريكي. وقد اعترف القضاء الأمريكي بحق الرئيس الأمريكي في إصدار أوامر عسكرية باعتبـار من يتت القبض عليه في حرب مـع البلاد من المقاتلين غير الشرعيين ويتم حبسه مدة غير محددة. ومع ذلك قضت المحكمة العليا في قضية Hamdi بضرورة احترام الحد الأدنى للاعوى العادلة والتي تتمثل في حق المحبوس في الطعن - ولو كـان ذلك أمسام محكمة

(1) "يقصد بضمانة ميراندا Miranda warning ضرورة تنبيه المتهم المقبوض عليه بالتهمة

$$
\text { وبالحق في محام...إلخ بيرن }
$$

"You have the right to remain silent. Anything you say can and will be used against you in a court of law. You have the right to an attorney. If you cannot afford an attorney, one will be provided for you. Do you understand the rights $I$ have just read to you? With these rights in mind, do you wish to speak to me?" http://www.mirandawarning.org 
عسكرية ـ في القرار الذي اعتبره من المقاتلين غير الثرعيين وكذلك الحق في الطعن في قرار حبسه ('). في نفس الوقت قضت محكمة المقاطعة في قضية Padilla بـان

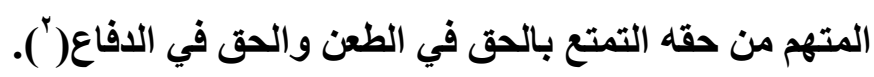
Rasul et alia v. US وقد اتجهت بعض أحكام للقضاء الأمريكي في قضئ فن فئسية إلى أن المقاتل الأجنبي الذي يحجز في منطقة جوانتيناموا لا يتمتع بالضمانات التي

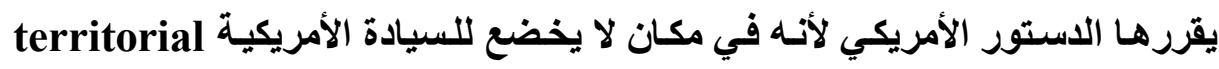

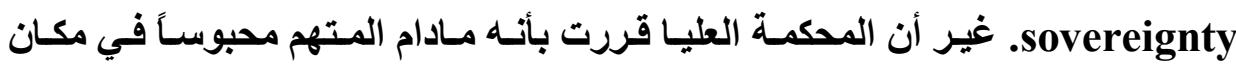

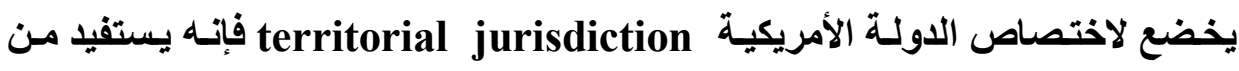
الضمانات الاستورية التي يقررها الاستور الأمريكي(").

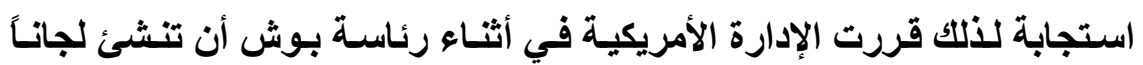

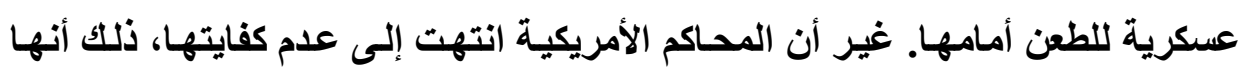

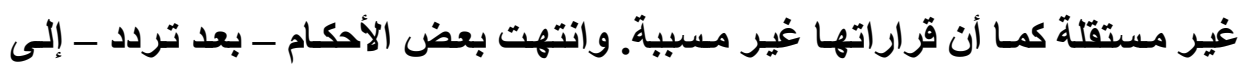
وجوب تطبيق اتفاقية جنيف على المقبوض عليهم باعتبارهم من أسرى الحرب.

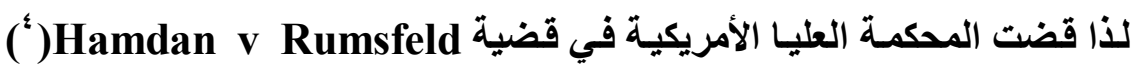
بأن هذه اللجان العسكرية مخالفة للقانون وللمادة (ॅ) من اتفاقية جنيف.

(1) Hamdi v. Rumsfeld, 316 F.3d 450 (4 thCir. 2003);Westlaw, 2004 WI 1431951 (US).

(2) $<$ http://news.findlaw.com/cnn/docs/padilla/padillarums72303padbrfpdf $>$ (3) $<$ http://www.supremecourtus.gov/opinions/03pdf/03-334.pdf $>$.

(4) http://www.hamdanvrumsfeld.com/05-184.pdf, 548 US 557 
ومن ناحية الأدلة المقدمة، يسمح بكل طرق الإثبات دون الاعتراض على طريقة

الحصول على تلك الأدلة، كما تقبل الشهادات السماعية hearsay ـ بنـاء عليه يقبل الدليل المستمد من المراقبة والتنصت دون إذن. وإذا قررت أغلبية المجلس أن المتهم غير مذنب، فإن رئيس المجلس يستطيع رغم ذلك أن يقرر أنه مذنب، الأمر الذي يخالف القواعد العامة في المحاكمات(').

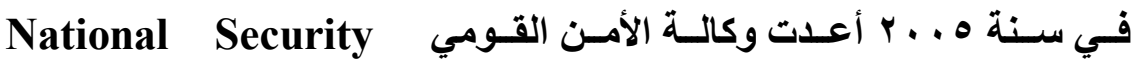
وطبقت برنـامج التجسس بـون شرط الحصول على إذن من محكمة FISA يخالف قانون FISA كما أنه يخالف التعديل الرابع للاستور. يضاف إلى ما سبق ما اتبعته الإدارة الأمريكية سنة ج ، . . من سياسة الاحتجاز غير العـادي Extraordinary rendition حيث يـتم تسليم الإرهـابيين إلى بـلاد بطريقة سرية، هذه البلاد لا تحترم حقوق الإنسان، بل تم اختطاف بعض الإرهابيين في بعض البلاد وتسليمهم إلى تلكك البلاد.

التوسع في هبال التنصت على المادثات الهاتفية والالكتزونية: بعد الهجمات على المباني الفيدرالية في مدينـة أوكلاهومـا الأمريكية والتي راح ضـحيتها 141 شـخص صـدر قـانون يسمح بالتتصت مـن جانب وكالـة الاستخبارات الأجنبية، كما وسع القانون من قدرة المخابرات على الاخول إلى بيانات مزودي خدمات الانترنت بمـا فيها وكالات السفر وبطاقات الائتمـان بمقتضى قانون المكافحة الشاملة للإر هـاب سنة هو 1990 Comprehensive Terrorism Act. كما أضـاف المشرع 
الأمريكي إلـى مجموعـة تشريعات مكافحسة الإرهـاب قـانون مكافحـة الإرهـاب وتفعيل Anititerrorism and Effective Death Penalty Act عقوبة الإعدام لسنة 1997 (AEDPA)

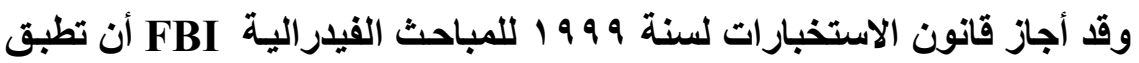
نظام التجسس على اتصالات شخص معين حتى ولو غير وسيلة الاتصال بنظام التبع لمعرفة الأثخاص التي يقوم هذا الثخص بالاتصال بهم دون معرفة محتوى الاتصال نفسه من ضمن التجديدات التي أدخلها القانون الوطني لسنة ا . . ب تخزين معلومـات البصمة الوراثية الخاصة بالأفراد المشتبه في أنهم من الإرهابيين أو بارتكابهم جرائم عنف (الفصل r • (). بل إن القانون الأمريكي يفرض على المؤسسات التعليمية الكثف

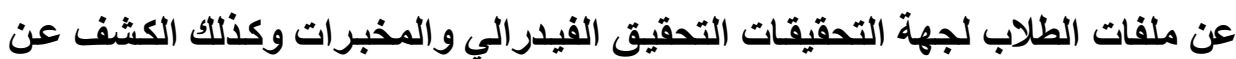
المواد التدريسية التي يدرسها بعض الطلاب (الفصل V.0 و الفصل 1 ـ 0). ونفس الالتزام يقع على عـاتق شـركات التسوق بالنسبة لأسـماء وغنـاوين الزبائن للديها و المتعاملين معها، بل وأسماء المستهلكين التي يمكن أن يحوزو ها (الفصل ه ه ـ ه). ومن ضمن تلك النصوص أيضا وضع نظام لاقتسام المعلومـات التي تحوزهـا الجهات الأمنية وهي المخابرات CIA ومكتب التحقيقات الفيدرالية FBI

\section{الاعتراض والتسجيل وتفتيش الاتصالات الرقمية والالكترونية:}

Katz سبق وأن قضت المحكمة العليا للولايات المتحدة الأمريكية ـ في قضية والية vأنه يلزم في تلك الحالات سبق الحصول على إذن من المحكمة بذلك عند تو افر

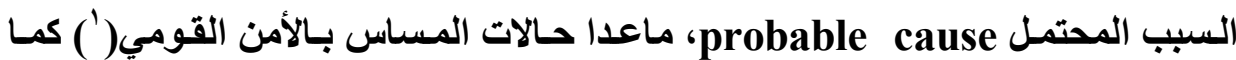
قضت- في قضية Berger v. New York - بأن الإذن بتسجيل الححادثات السلكية 
واللاسلكية يجب أن تكون محددة من حيث الشخص المقصود والوسيلة المتبعة في التسجيل ومدة التسجيل(') (').

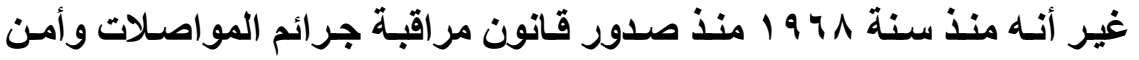
الشارع Omnibus Crime Control and Safe Street 1968 أجـاز المشرع الأمريكي لرئيس الدولة اتخاذ من التدابير المناسبة مـا تستلزمه ضرورة حمايـة الأمن القومي من الهجمات الحالية أو المحتملة أو غيرها من الأفعال العدائية من جهة أجنبية ومنهـا الحصول على المعلومـات الخاصـة بالاسـتخبارات الأجنبيـة. وهذا يعنـي جـواز التنصت والتسجيل لمحادثات سلكية أو لاسلكية أو الكترونية أجنبية أو محلية بدون إذن بغرض حمايـة الأمسن القومي. تطبيقـا لـذلك قضت المحكمـة العليـا للولايـات المتحـدة الأمريكية سـنة Y Y Y ـ في قضية Keith- بـأن اشتراط الإذن للتسجيل يقتصر على الاتصالات المحلية ولا يسري على الاتصالات الخاصة بجهة أجنبية('). وقد عرّف قانون الاستخبارات(FISA) سنة 19 V الاستخبارات الأجنبية التي يمكن جمعها دون إذن وتسجيلها بأنها المعلومـات المتعلقة بأنها "المعلومـات المتعلقة بالقدرات والمخططات أو الأنثطة الخاصة بالحكومات الأجنبية أو لجهات تابعة لها أو لتنظيمـات أجنبيـة أو أثـاص أجانب أو أنشطة إرهـاب دوليـة" ( 50 USC S.) ( $\left.{ }^{r}\right) 401(a)$

(1) Berger v. New York, 388 US 41 (1967).P

(2) US v. US District Court (Keith), 407 US 297 (1972).

(3) "information relating to the capabilities, intentions, or activities of foreign governments or elements thereof,

foreign organizations, or foreign persons, or international terrorist activities" (50 USC s. 401(a)). 
و الأصل في التنصت أو التسجيل للمحادثـات التـي تجري بطريق السلكي أو

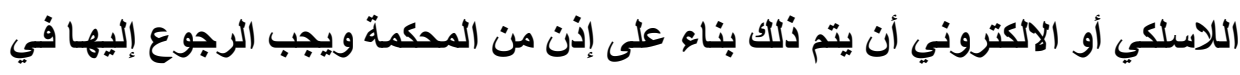

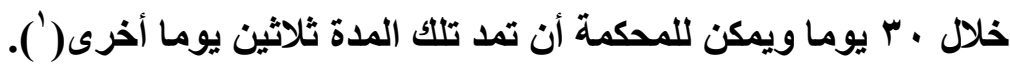
غير أنه يجوز الاستغناء على صدور الإذن من المحكمة في حالـة الاستعجال

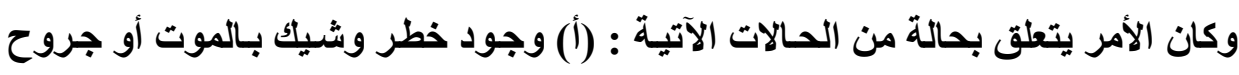

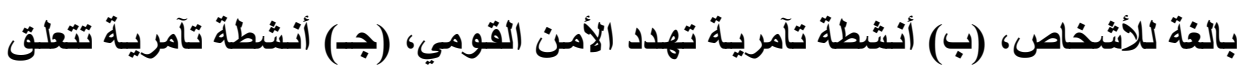

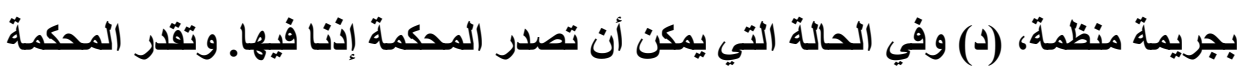
صحة الإجراءات بدون إذن بعد حدوث التنصت أو التسجيل في حدود ^ ^ ساعة.

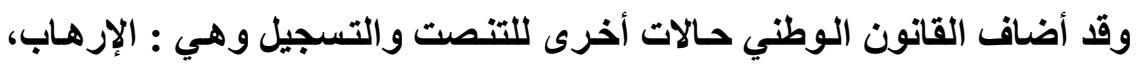
الغش عن طريـق الكمبيوتر و إسـاءة استعمال الكمبيوتر(الفصل I ـ ب مـن القـانون

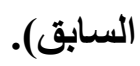
كما ساهم القانون الوطني في التوسع في مفهوم التنصت والتسجيل بحيث يتم

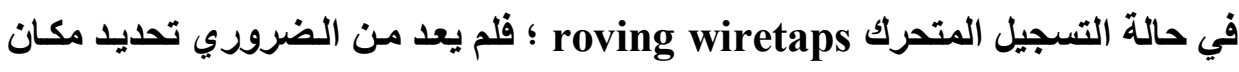

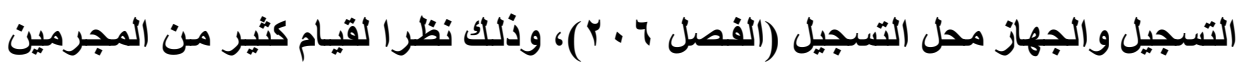

$$
\text { بتغيير هواتفهم لإغراض إجرامية. }
$$

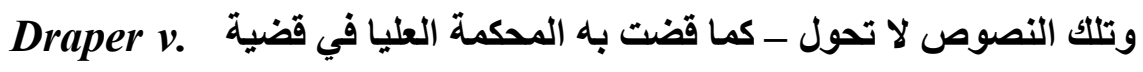
- US استخبارية بخصوص قوى أجنبية وذلك لصالح الأمن القومي وبدون سبق الحصول 
على إذن بذلكك ولكن مـع السبب المحتمل (الدلائل الكافية)( (') ("). وقد كرس القانون الأمريكي تلكا السلطة لكي يعصمها من عدم المشروعية 18 USC)

فمنـ حكم Keith الصادر مسن المحكمـة العليـا لا يلزم صدور إذن للتنصت والتسجيل على الاتصالات مادام أن الجهة المقصودة هي جهة أجنبية(ّ) آمـا إذا كاتت جهة داخلية أو مواطن أمريكي أو مقيم، فِان الإذن يصبح ضروريا. هذا الإذن يصدر

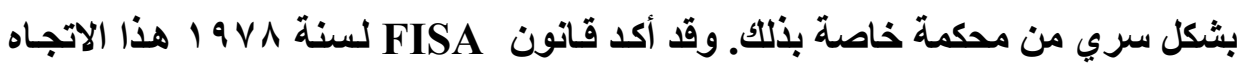

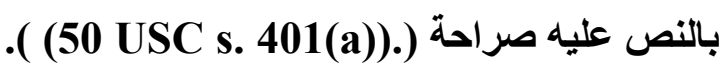

\section{التنصت والتسجيل بإذن المكمة:}

الأصل أن التصت والتسجيل للاتصالات يتم بإذن المحكمة ولكن يشترط لإصدار الإذن توافر السبب المحتمل probable cause وأن يكون ذللك عن جريمة من الجرائم

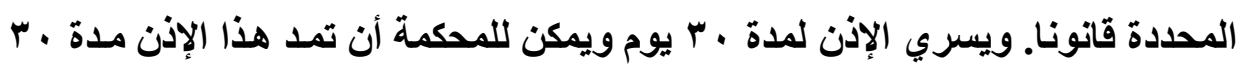

$$
\text { يوما أخرى. }
$$

وفي حالة ما إذا كـان الشخص أو الجهة المطلوب التجسس عليها أو التسجيل

لها جهة أو شخصا أجنبيا، فبان الإذن - وفقا لقانون FISA يكون لمدة م و يومـا، ويمكن أن يمتد إلى سنة، ويجوز في حالة التسجيل من تليفونـات متغيرة roving أن يصدر الإذن لمدة • r ا يوما. ويصدر الإذن من محكمة خاصة بذلك وبشكل سري(").

probable cause (' )

(2) Draper v. US, 358 U.S. 307 (1959).

(3) US v. US District Court (Keith), 407 US 297 (1972).

(4) JOHN A.E. VERVAELE, id, p. 22.

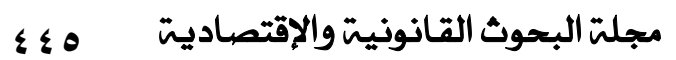




\section{الاستعانة ببراهج التتبع للمحادثات والالكترونية:}

يجوز استخام برامج تسمح بتتبع اتصالات شخص معين ومعرفة من يتحدث

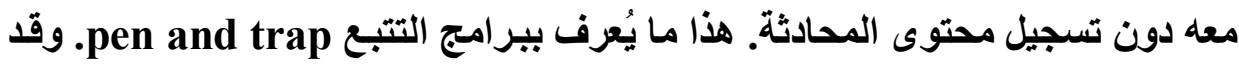

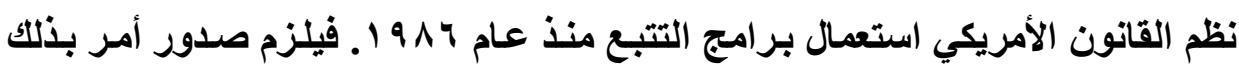
من المحكمة بخصوص جمع الأدلة عن جريمة يتم التحقيق فيها. وقد كاتت المتابعة في

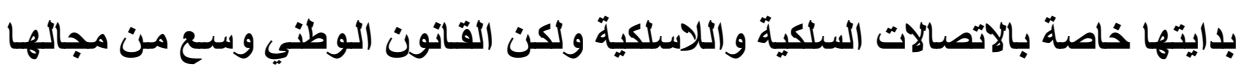
email address بحيث تنطبق على الاتصالات الإكترونية فتتـد إلى عناوين الايميل

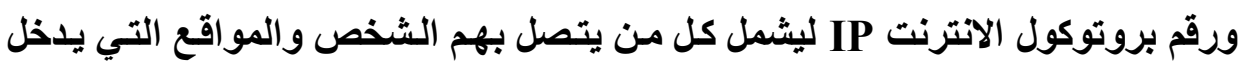

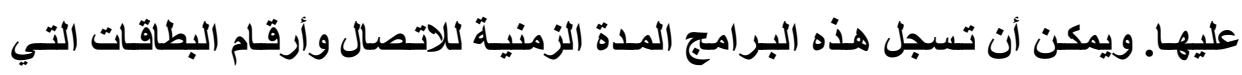
يستخدمها الثخص وأماكن تواجده هو ومن يتصل بهم والخدمات التي يطلبها من غيره

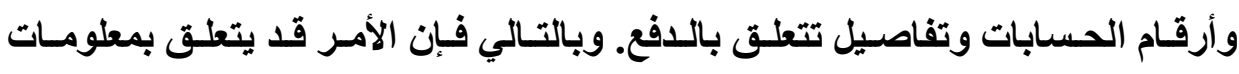

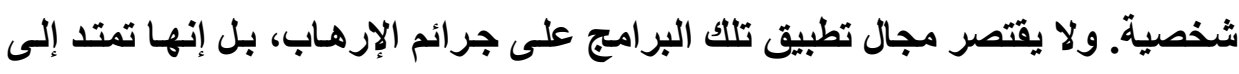

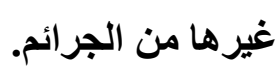
ونظرا لان الاتصالات السلكية واللاسلكية والأكترونيـة لا تقتصر على دائرة

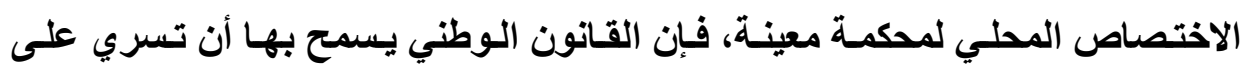

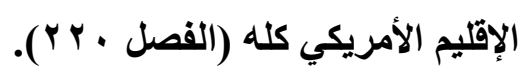

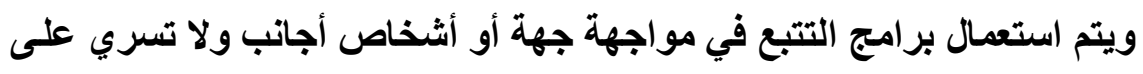
المواطنين الأمريكيين حتى لا يتعرض المواطنون للتجسس عليهم. وقد تبنى القانون

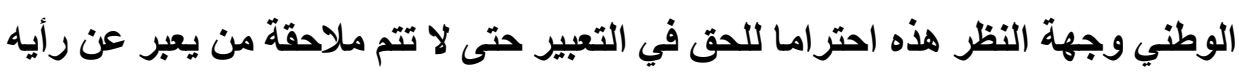

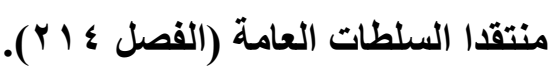




\section{إلزام هزودي الخدهات بتقديم المعلوهات:}

وسع القانون الأمريكي من الحالات التي يلتزم فيها مزودي خذمات الانترنت بالتعاون مع مأموري الضبط القضائي بحيث يقدمون مـا يطلبه الآخرون من معلومـات عن مستخدمي خدمات الإنترنت مثل المعلومات الثخصية المتعلقة بحساباتهم ووسائل دفعهم وأرقـام بطاقـات الاتتمسان التي يدفعون بها أو أرقام حساباتهم في البنوك. كمـا

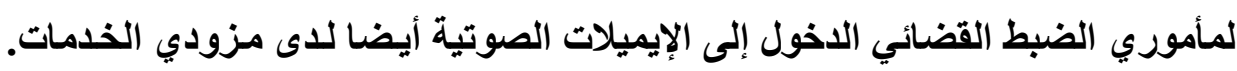
ولا يلزم لذلك سبق الحصول على إذن قضائي بذلك.

وقد جاء هذا التوسع بسبب موجات الإرهاب والرغبة في الكثف عن هويـة الإرهـابيين. لـذا أدخل المشرع الأمريكي تلكت التوسـعات بمقتضى القـانون الـوطني Partriot Act

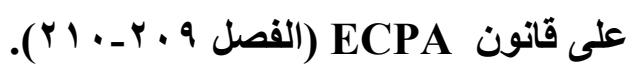

وقد سوي المشرع الأمريكي بين مزودي خدمات الإنترنت ومزودي خدمات

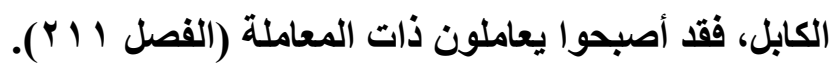

ولم يعد منطلبا للحصول على تلك المعلومسات من مزودي الخدمات تصريح

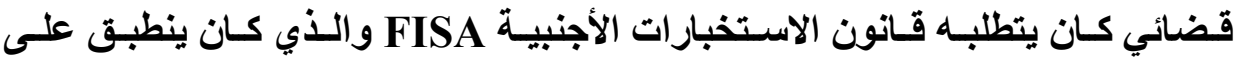
الجهات الأجنبية وعملائها ويسمح بالتجسس على اتصالاتهم وذلك لضبط الجرائم

\section{التوسع في حالات التفتيش:}

تقتضي القواعد العامـة في التفتيش وجوب إذن قضائي بالإضـافة إلى تـوافر knock and بوقوع جريمة مي تطبيق قاعدة بالأسباب المحتملة probable cause 
Patriot announce (') أمـا في جرائم الإرهـاب فقد خفف منهـا القانون الوطني Act وأصبح يحل محلها قاعدة sneak and peek (فصل r T Y). كمسا لم يعد متطلبـا إخطار صـاحب الشأن بالتفتيش notice of search وذلك بسبب تعرض الأشخاص للخطر إذا حدث ذلك أو تهديد الشهود أو التأثير في الأدلة. ويفرق قانون FISA فيما يتعلق بمراقبة الاتصالات بين الجهة الأجنبية وعميل تللك الجهة من المواطنين. ففي الحالة الأولى لا يلزم سبق الحصول على إذن قضائي مع اشتراط السبب المحتمل probable cause ولكن هذا الإذن يلزم الحصول عليه في الحالة الثانية)( ).

\section{ضمانات الدعوى العادلة بالنسبة لعضو المنظمة الإرهابية:}

يجب أن يتمتع الإرهـابي بضمانة اللدعوى العادلة. وإذا ضـم ضبطه في أثنـاء عمليـات عسكرية، فـلا يسوغ وصـفه بأنـه مقاتـل غيـر شـرعي لتجريــه مـن حقهـ في المحاكمة العادلة. وقد كان ذلك هو مصير سجناء جوانتينـاموا الذين لـ يكن لهم الحق

$$
\text { في دعوى عادلة ويذكرونا بالعبيد الذين لم يُعترف لهم بحقوق("). }
$$

وقد كان معتقلو جوانتاناموا غير خاضعين للقضاء الأمريكي بسبب وضعهم في معسكرات خـارج الإقليم الأمريكي، كمسا ترتب على ذلك أنهـم أصبحوا مجردين مـن

يقصد بها قاعدة الطرق على الباب والإعلان عن المقصد. knock and announce (1) https://www.law.cornell.edu/wex/knock-and-announce_rule

(2) JOHN A.E. VERVAELE, id, p. 25

(3) Konrad Lachmayer, Constitutional and Anti-Constitutional Responses to Terrorism: The Difficulty of Removing Exclusions from Constitutional Law, 2 City U. H.K. L. Rev. 52010 , p. 5 : http://heinonline.org 
الحقوق المقررة في القانون الجنائي. يُضاف إلى ذلك أن السلطات الأمريكية لم تعتبرهم أسرى حرب لأنهـ لـم ينخرطوا في حرب نظاميـة ضد الولايـات المتحدة واعتبرتهم

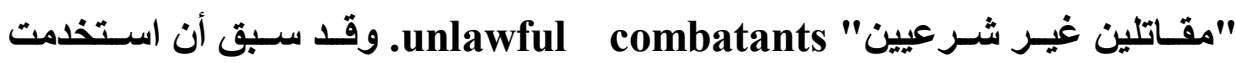
Ex parte المحكـة العليا للولايـات المتحدة هذه الاصطلاح في قضية قديمة وهي (1942) Q في هذه القضية ميزت المحكمة بين المحاربين وبين المدنيين، كما ميزت بين المحساربين الشرعيين والمحساربين غير الشر عيين. الطائفة الأولى تعتبر أسرى حرب عند أسرهم، أما الطائفة الثانية فإنها تخضع للمحاكم العسكرية لمخـالفتهم لقوانين الحرب عندما اشتركوا في الحرب وهم ليسوا طرفا فيها. من الطوائف الأخيرة الجاسـوس الذذي يــخل بشكل سـري في الخطوط الخلفيـة للجيش غير مرتــ للززي العسكري لجمع معلومات وتوصيلها للجيش المعادي، ويمن يتسلل في صفوف الجيش غير مرتد للزي العسكري بغرض التخريب والقتل وإثارة الحروب. هؤلاء لا يعتبرون أسرى حرب، بل هم مقاتلون غير شرعيين في قضاء هذا الحكم('). وقد تطور موقف المحكمة العليـا للولايـات المتحدة حيث اعتبرت ـ في قضية

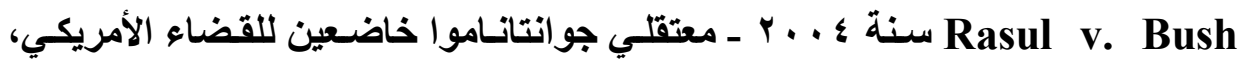
استنادا إلى الأسباب التالية : اــ لـ يكن المعتقلون من رعايـا دولة في حالة حرب مـع الولايات المتحدة حيث كانوا ينتمون إلى دول مختلفة وكـانوا متواجدين في أفغانستان، r ـ المعتقلون أنكروا انضمامهم إلى أية قوات تقاتل الولايات المتحدة، بـ المعتقلون لـ يتمتعوا بالحق في تحديد تهمتهم والحق في سماع أقوالهم، وهي أساسيات العدالة، عـ ـ 
الولايات المتحدة كان لها السيطرة على معسكر جو انتيناموا ولمدة تجاوزت السنتين

$$
\text { وقت اعتقالهم هناك('). }
$$

Hamdi v. وقد أكلت المحكمة العليا ذلك القضاء في حكم آخر لها وهو حكم

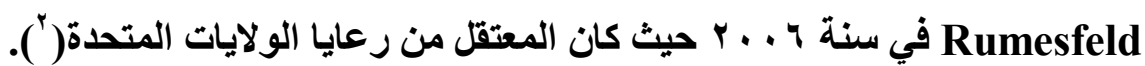

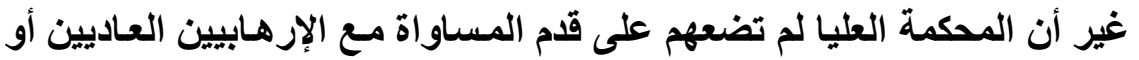
مـع أعضاء المنظمـات الإرهابيـة العاديـة. فعلى الرغم مـن أنها أكلدت حقهم في العلم

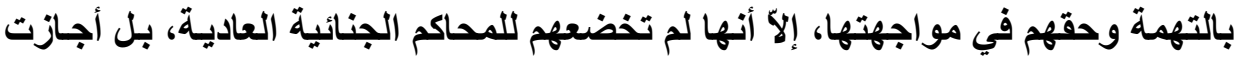
خضوعهم للمحاكم العكرية، كمـا أنها أجـازت استخدام الحبس الاحتياطي غير محدد المدة في مواجهتهم("). وقد أكلت المحكمة العليا في ذلك أن اللجان العسكرية غير دستورية حيث إنها لم تنشأ بقانون كما أنها لا تقام الحد الأدنى للمحاكمة العادلة لمعتقلي جوانتاناموا("). في مواجهة اتجاه المحكمة العليا لجأت الإدارة الأمريكية إلى إجراءات جديدة،

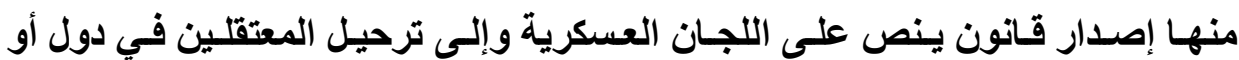
مناطق غير معروفة، والثانية هي وضعهم في حبس سري. ومن جديد وفي ظل هذا السجال بين الإدارة الأمريكية و المحكمة العليا، قضت فئرئ تلك الأخيرة - في قضية Boumedine v. Bush بأن اللجان العسكرية في شكلها

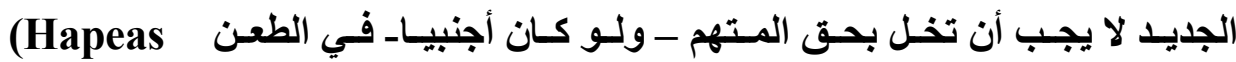

(1) 542 US 466 (2004)

(2) Hamdan v Rumsfeld 548 US 557 (2006)

(3) Hamdan v Rumsfeld, id

(4) Hamdan v Rumsfeld, id

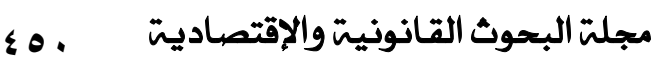


كما أن وضع المعتقلين خارج إقليم الدولة لا يخل بحقوقهم الدستورية في Corpus)

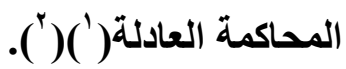

\section{هميار التنـاسب في الإجراءات عند هكافمة التنظيسمات الإرهابية:}

تحرص كثير من التشريعات على معيار التناسب عند مكافحة ظاهرة التنظيمات

الإرهابيـة، بـل إن الدستور الألمـاني ينص صراحة على ضرورة التناسب عند تقييـا

$$
\text { الحقوق والحريات بعد شرط الضرورة) بَّ). }
$$

وفي هذا المجال أصبح متناسبا في تشريعات مختلفة زيـادة سلطة الشرطة في

حجز المتهم بحيث تصل تلك المدة إلى سبعة أيام وفقا مكافحة الإرهاب في استراليا("). غير أنه وفقا للقانون الاستر الي لا يلزم لحجز الشخص أن يكون متهما بتهمة معينة، بل يكفي أن يتوافر شك لدى رجـال الشرطة وأن يكون حجز الشخص مفيدا في بتجميع معلومات في مجال الإرهاب (الفصل رقم 34D من القانون سابق الأكر).

(1) Boumedine v. Bush, 553 US (2008) 723.

(2) GL Neuman, 'The Extraterritorial Constitution after Boumediene $v$ Bush' (2009) 82 Southern California Law Review 259.

(3) Christopher Michaelsen, The Proportionality Principle, Counterterrorism Laws and Human Rights: A German-Australian, Comparison, 2 City U. H.K. L. Rev. 5 2010, p.19 :http://heinonline.org

(4) Australian Security Intelligence Organisation (Terrorism) Act 2003 
وهناك من مظاهر عدم التناسب عند مكافحة الإرهـاب في استراليا أن الشرطة تحصل على إذن بحجز الأشخاص في الظروف السابقة من أشخاص كانوا قضاة ولكنهم خرجوا على المعاش ولا يتمتعون بميزة الاستقلال('). ويشكل ذلك مخالفة لمقتضيات

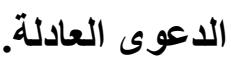

يضاف إلى ذلك أن القانون الاستر الي يسمح للشرطة عند حجزهـا المشتبه فيه في الظروف السابقة أن توجـه إليهه أسئلة بـدون حضور محاميه، كمـا أنـه في مرحلة لاحقة عندما يلتقي المشتبه فيه ومحاميه فبان تلكك المقابلة هي محل مراقبة ( ASIO (Act s 34C(3B). وقـ ازداد الأمـر مخالفـة للـدعوى العادلـة في اسـتر اليا بمقتضى قـانون صـادر ]كافحة الإرهاب في سنة ه . . The Anti-Terrorism Act [No. 2] 2005) حيـث أجـاز أولاـ الحـبس الوقـائي preventative detention وثثانيـا - أوامسر المراقبة control orders. وتشمل أوامر المراقبة عدم التردد على مكان معين أو عدم السفر من استر اليا أو أشخاص معين وعدم القيـام بأعمـال معينة منهـا استعمال شبكة الانترنت. ويمكن أن يشمل ذلك الإلزام بالبقاء في مكان معين في أوقات معينة من النهار أو الإلزام بلبس جهاز صغير في معصمه للمتابعة. ومن يخالف هذه الالتزامـات

$$
\text { يعاقب بعقوبة الحبس() ). }
$$

وقد وضـع القـانون الاستر الي ضمانة تتمثل في أن الشرطة تطلب مـن قـاض السماح لها بفرض أمر المراقبة أو الحبس الوقائي على شخص معين. غير أنه من

(1) C Michaelsen, 'International Human Rights on Trial: The United Kingdom's and Australia's Legal Response to 9/11' (2003) 25 Syd LR 275

(2) Christopher Michaelsen, id, p.40

مجلتّ البحوث القانونيت والإقتصاديت 
الناحيـة الموضسوعية لا يشترط وجود اتهام بجريمـة بـل يكفي أن يسمح فرض تلتك

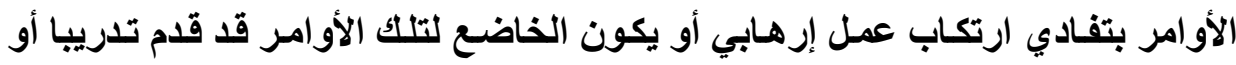
تلقى تدريبا من منظمة موضوعة على قائمة الإرهاب.

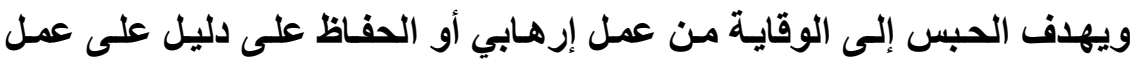

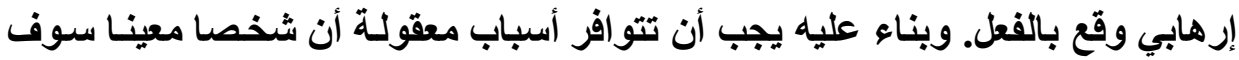

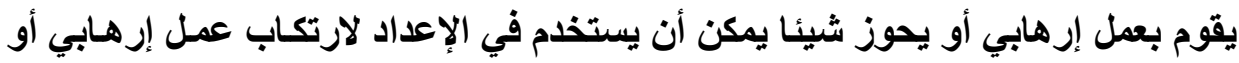

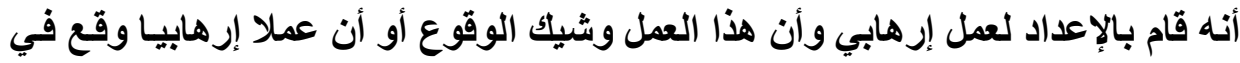
خلال ^Y يوما وأن حبس المشتبه فيه وقائيا يفيد في الحفاظ على الدليل على العـل

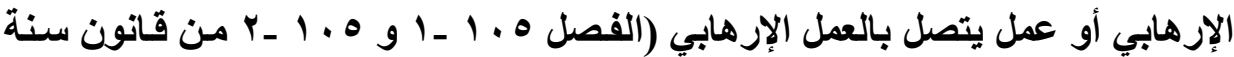

أمسا عن مدة الحبس الوقائي فهي ^ ؛ سـاعة. ويمكن أن تفرض السرية على المحبوس ولا يتصل إلاً بححاميه أو بأقاربه.

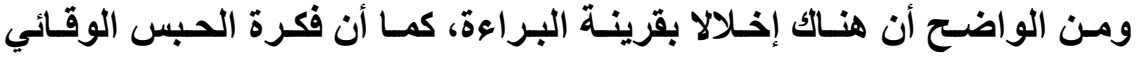
تخالف الحقوق والحريات الفردية. كما أنه لا يشترطوقوع جرئه الفريمة معينة، بل يكفي أن يكون هنـاك احتمـال وقوع عمل إرهابي. ولا يشترط أن يكون العمل الإرهابي جريمـة إرهابية، بل يكفي أن يشكل إعداداً لهذا العمل الإرهابي. استخدام المعلومات المبرهجة في تبميع بيانات عن التنظيسمات الإرهابية: صدرت قوانين في بعض الدول تسمح للشرطة بالاستفادة من البيانات المبرمجة في جهات عامة أخرى مثل المدارس والضر ائب والهجرة والبطاقات المدنية وغيرها

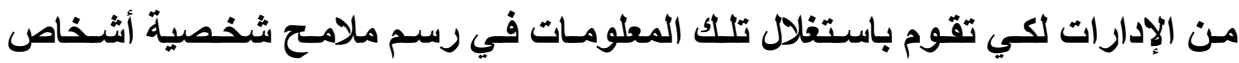
معينة data mining حتى إذا ما تو افرت تلك الملامح أصبحت الثخصية محل اهتمام 
لرجال الأمن لمتابعتهم من ناحية علاقتهم بالتنظيمـات الإرهابية. فمثنلا لو وضعوا من ضمن الملامسح أن يكون الشخص لـه أصول مسلمة، أن يكون ممن سـافر إلى الشرق الأوسط قريبا، أن يكون قد سـافر أكثر من مرة في السنة، أن يكون متديناً، أن يكون ملتحيا .... وهكذا فإذا اجتمعت تللك الملامح في أشخاص معينـة كانوا مرشحين لمتابعة من الشرطة الخاصة بمكافحة الإرهـاب. وقد استخدمت الشرطة الألمانية تلك الوسيلة في مكافحة الجيش الأحمر الإرهابي منذ سنة ب Y Y ('). وقد طبقت الثرطة الألمانية هذا النظام في قضية BVerfG (†) وهو مغربي رفع دعوى أمام المحكمة الفيدرالية الألمانية بسبب استعمال تلكك التقتية وذلك بطلب بيانات مبرمجة ضده والقيام بمراقبته على هذا الأساس تطبيقا للفصل اس من NRW قانون الثرطة. وقد لاحظت المحكمة في هذه القضية أن استعمال البيانـات المبرمجة للدى الهيئـات الأخرى كـان محددا في اسـتعمال لغرض معين وأن تلكـ البيانـات يـتم التخلص منها بعد أداء الغرض منها أو العدول عن تحقيق ذلك الغرض وأن الشرطة تستخدم تلك التقنية بعد الحصول على إذن من القاضي("). في هذه القضية قضت المحكمة بـأن النص الذي يسمح للشرطة بعدل ملامـح للأفراد بناء على المعلومات المبرمجة من الجهات المختلفة هو عمل وإن كـان يخالف حق الأفراد في السيطرة على المعلومات الثخصية الخاصة بهـ، إلا أن غرض مكافحة الإرهاب يبرر ذلك. فالوسيلة ضرورية وهي متناسبة ويجب استعمالها بهذا القدر.

(1) Christopher Michaelsen, id, p.32

(2) BVerfG, 18 July 2005, 2 BvR $2236 / 04$ <www.bverfg.de/entscheidungen/rs20050718_2bvr223604en.html>.

(3) G Kett-Straub, 'Data Screening of Muslim Sleepers Unconstitutional' (2006) 7 German LJ 967. 
غير أن المحكمة في حكمها السابق أكلت على أنه يجب أن يشبت أسباب معقولة للاعتقاد بأن شخصاً معيناً ينتمي إلى تنظيمات إرهابية أو يقوم بالإعداد للقيام بأعمال

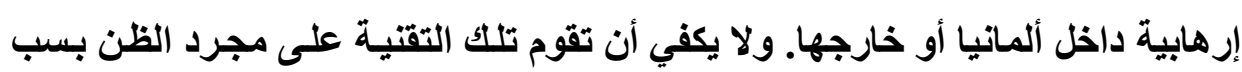
الأصول المسلمة أو غير ذلك مما لا يجد له أصلا من وقائع محددة. كما لا يبرر استعمال تلك التقتية التخوف من موجة الإرهاب منذ الحادي عشر من سبتمبر. نتائج وتوصيات البحث

في نهايـة هذا البحث عن السياسة الجنائية المعاصرة في مواجهة التنظيمات الإرهابية نتتهي إلى نتائج وتوصيات، من أهمها: أولاًا - النتائج:

- القواعد التقليدية في قانون العقوبات تعجز عن مكافحة التنظيمات الإرهابية. لذا فإنه من المتعين اللجوء إلى قو اعد خاصة تواجه الطابع الخاص لتلتك التظظيمات.

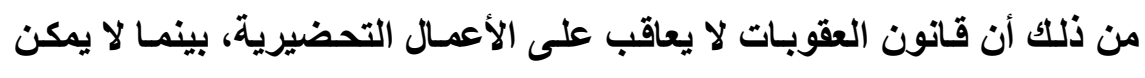

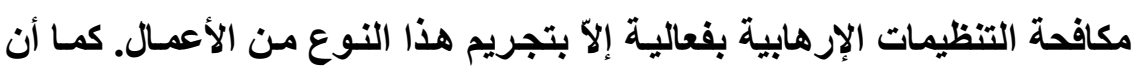

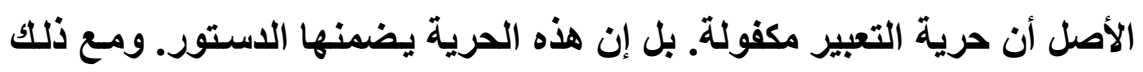

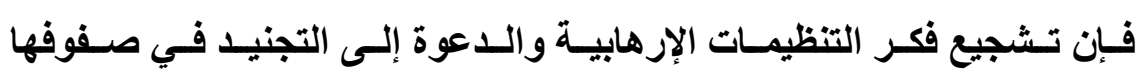
واستحسان مذاهبها أصبح أمرا واجبا مكافحته عن طريق العقاب عليه.

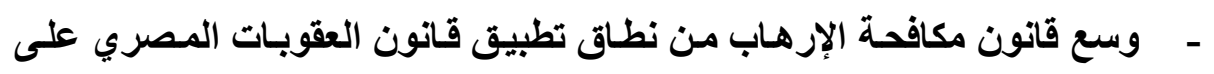

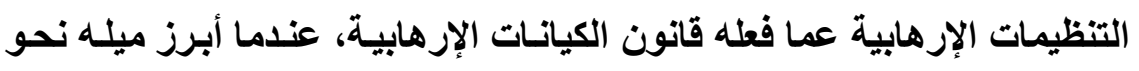

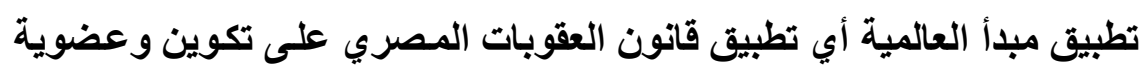

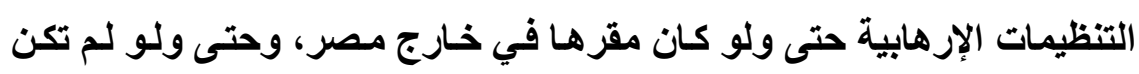


تستهدف مصالح مصرية، وبغض النظر عن جنسية أعضائها أو المسئولين عنها. - يسود اتجـاه في القـانون المقارن نحو تبنـي مبدأ العالميـة في تطبيق قـانون

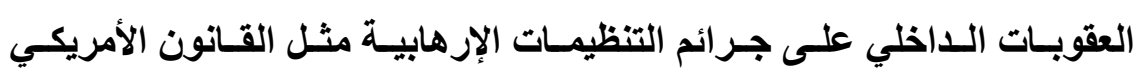
والقانون الإنجليزي وقانون دولة الإمارات ... - يلزم توافر قصد جنائي خاص يتمثل في قصد الترويع لقيام جرائم التنظيمـات الإرهابية، فلا يكفي إذن توافر القصد الجنائي العام.

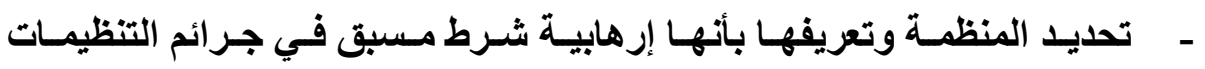

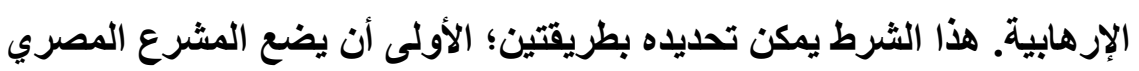

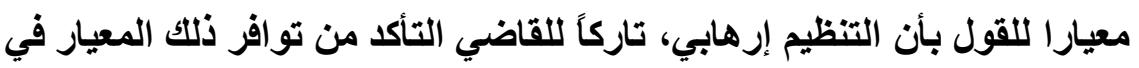

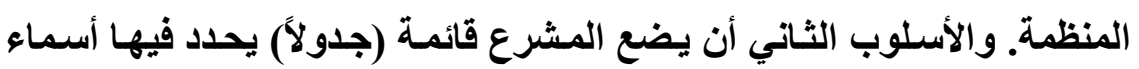

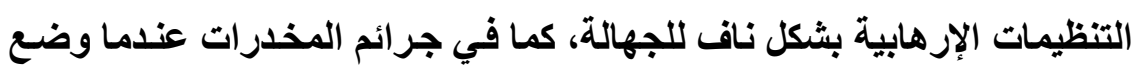
المشرع جدولا بالمواد المخدرة. - يجوز أن يضع المشرع قائمة بالتنظيمـات الإرهابية ميع تفويض وزير الاخلية

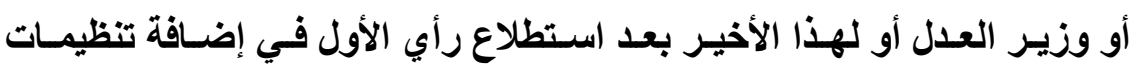

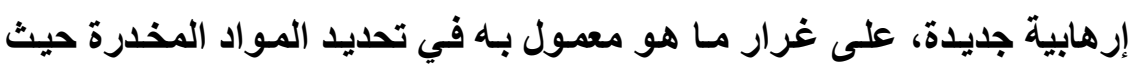
فوض المشرع وزير الصحة في الحذف والإضافة. - تختلف التثريعات المقارنة في آلية تحديد التنظيمات الإرهابية؛ فمنها مـا يعطي

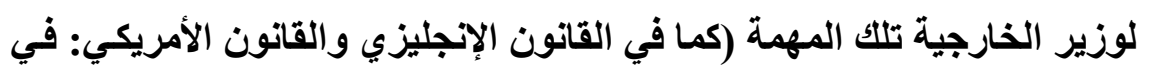
هذا القانون الأخير يصدر وزير الخارجية بعد التشاور مـع وزير المالية هذا لتانيل 
القرار) ومنها مـا يكلف المحسامي العـام بها (كالقـانون الأستر الي) ومنها مـا يستلزم صدور قرار بذلك من مجلس الوزراء (كالقانون في دولة الإمسارات)

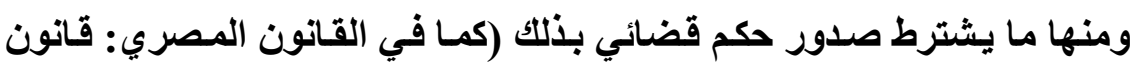

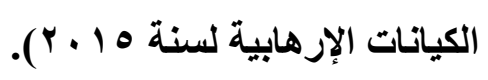
- ت تناول قانون مكافحة الإرهاب في مصر لسنة هـ 1 ـ ب تعريف التنظيم الإرهابي

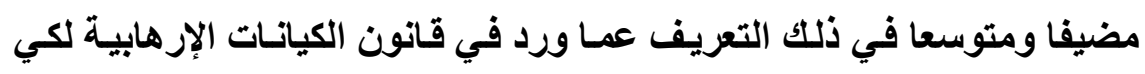

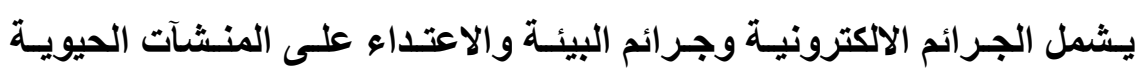

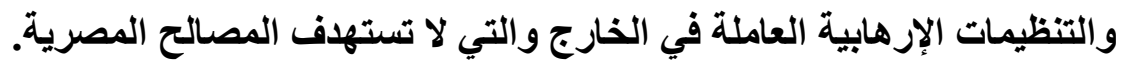
- يتعين أن يستفيد القائمون والأعضاء في منظمة إرهابية وكذلك الكيان الإرهابي ذاته من قو اعد الدعوى العادلة؛ ومنها الحق في المحاكمة أمسام جهة قضائية والحق في العلم والحق في الدفاع والدق في الطعن. - أصبحت التشريعات المقارنة تنص على مجموعة من التدابير مثل حظر الكيان الإرهابي ووقف نشاطه وتجميد الأموال وحظر التعامل مـع التنظيم الإرهابي

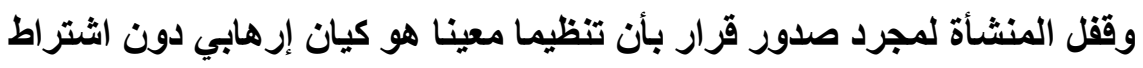
أن يصدر حكم بتلك التدابير. - تلتزم الدول باحترام قرارات الأمم المتحدة التي حلدت مجموعة من التظيمـات

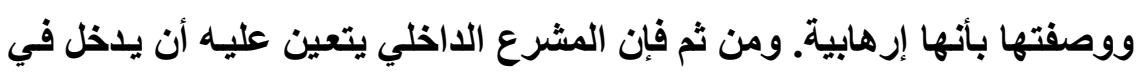

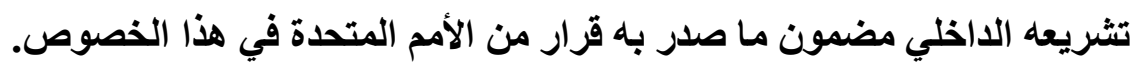

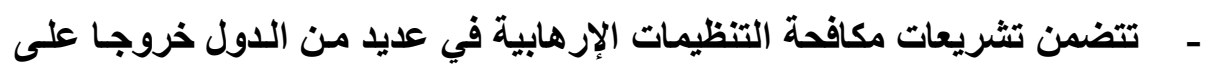

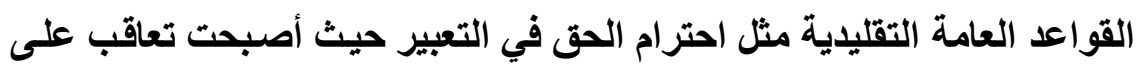


إبـاء الـرأي في تأييـد أفكـار تلك التنظيمـات، وحيث يمكن أن ينطبق وصـف التجريم على ممارسة الحرية النقابية كما في حالة تنظيم مظاهرات للضغط على الحكومة للقيام بعمل معين كالمطالبة بزيادة الأجور أو بتنحي الوزارة أو بغيرهـا من المطالب السياسية، مع الاستعانة بأساليب مثل الاعتصام ومحاصرة منشأة أو جهة معينة لمنع العمل بها. - ت تتضمن تلك التشريعات أيضا خروجـا على القواعد العامـة التقليديـة في قانون العقوبـات عند تبنـي آليـة معينـة لتحديـ التظظيمـات الإرهابيـة تعتمــ على قيـام السلطة التففيذيـة بتحديد التنظيم الإرهابي وعند عدم احترام قواعد الـدعوى

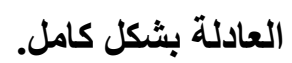
- تضضمن تشريعات مكافحة التظيمات الإرهابية ما يمكن أن تتصادم بـه مـع الحق في تكوين جمعيات وهو من الحقوق الاستورية. - تكرس تشريعات مكافحة التظيمات الإرهابية مسئولية مدير التظيم أو المسئول عنه عن الجرائم التي تقع من أعضاء هذا التنظيم على غرار مسئولية الفاعل والثريك عن الجرائم المحتملة لجريمة الفاعل الأصلي. - إن تقرير المسئولية الجنائية لمدير التظيم أو المسئول عنه عن الجرائم التي تقع من أعضائه يشكل توسعا واضـحا عمـا تقرره القواعد العامـة في مسئولية الفاعل مـع غيره والشريك عن النتيجـة المحتملة للفاعل الأصلي. ذلك أن تلك المسئولية الأخيرة لا تقوم إلا بتحديد الجريمـة الأصلية المتفق عليها. أمـافي حالـة مسئولية مـير التظيم فإنها تقوم عن الجرائم الإرهابيـة التـي يرتكبها 
أعضاء التنظيم حتى ولو لم يتم الاتفـق على نوعية تلتك الجرائم؛ فيكفي أن

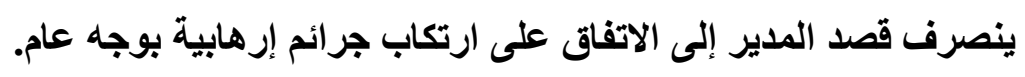
- إن تجريم العضوية في تنظيم إرهابي يلزم لتوافره قيام العضو بنشاط يدل على

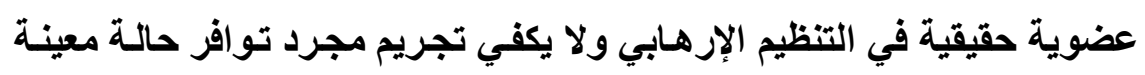
و هي العضوية دون قيام بنشاط حقيقي يتمثل في الركن المادي لتسلك الجريمة.

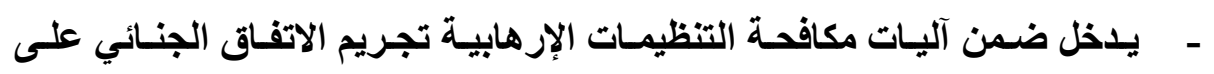

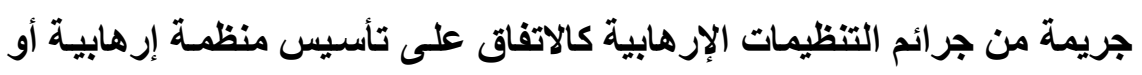

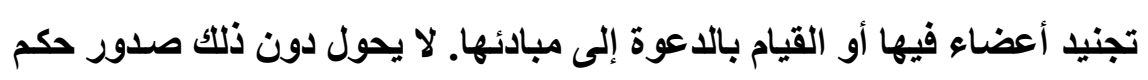

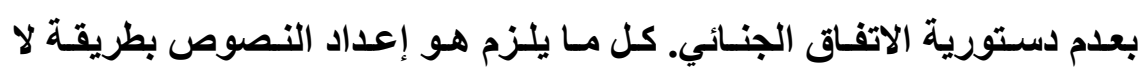
تتصادم فيها مع أحكام الدستور. - تكرس تشريعات مكافحسة التظظيمـات الإرهابيـة في مصر والقـانون المقـارن نصوصا تقرر مسئولية الشخص المعنوي من الناحية الجنائية في شكل حل التظيم وققل المنثأة و الغرامة. - يجوز الحبس الإداري للأجنبي المقرر طرده من البلاد لعلاقته بتنظيمات إرهابية

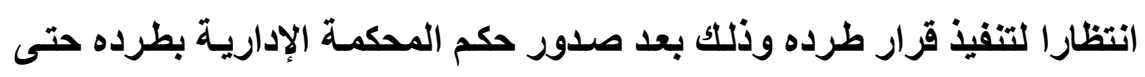

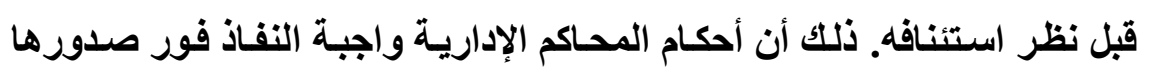
وقبل استنتافها. - يجوز الاستناد إلى تحريـات ذوات طابع سري كأسساس للحكم الصادر بطرد الأجنبي الذي يشتبه في علاقته بتنظيم إرهابي. 
- - أصبح من المقرر أن القواعد الإجرائية لمكافحة الجرائم الإرهابية تخرج عمـا تقرره القواعد العامة للإجراعات الجنائية من ناحية القبض والتفتيش وإطالية مدة الحبس الاحتيـاطي وتخصيص دوائر لجرائم الإرهـاب ومـن المرونـة في تطبيق قواعـد تسجيل المحادثـات الهاتفيـة والإكترونيـة ومسن إلـزام مـزودي الخدمات بالتعاون مع السلطات. بل أصبح واجب التبليغ والتعاون في مجال تلكت الجرائم يعاقب على الإخلال به جنائيا. ثانياًا- التوصيات:

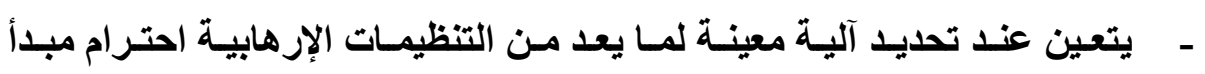

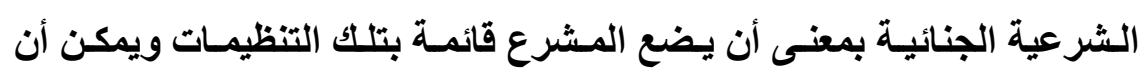
يفوض وزير العدل بالحذف والإضافة لجدول التنظيمات الإرهابية. ويعد ما اتبعه المشرع المصري في هذا الشأن مناسبا حيث وضـع المشرع المعيـار ويحدد القاضي ما إذا كان تنظيم معين إرهابيا أو لا. - يتعين أن يحترم تجريم التتظيمات الإرهابية المبادئ الدستورية الأساسية ومنها الحق في التعبير والحق في تكوين جمعيات والحريات النقابية. - يلزم أن يستعين المشرع بتجريم الاتفاق الجنـائي في مجـال الإرهـاب بوجهـ عام

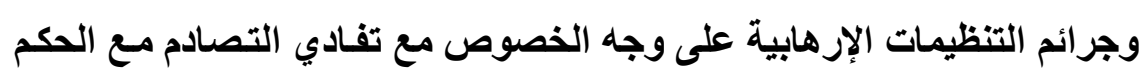

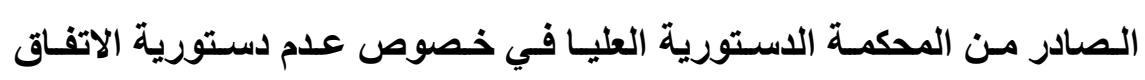

$$
\text { الجنائي بوجه عام. }
$$

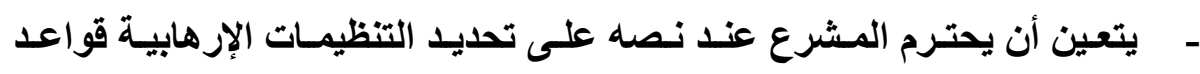

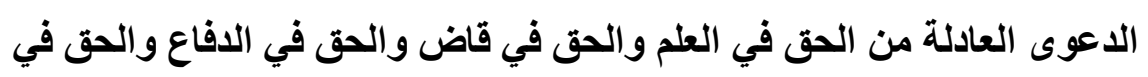

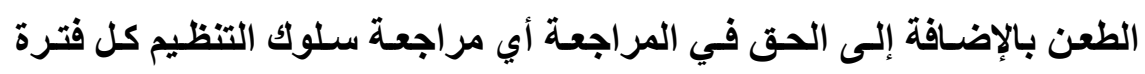


معينة لرفع اسمه من قائمة التظظيمـات الإرهابيـة أو مراجعة الحكم الصادر ضد التنظيم.

- يتعين التحوط عند تقريـر مسئولية مـدير التنظيم عن الجرائم التـي يرتكبهـا التظظيم أي أعضاء التظظيم باشـتراط أن ينصرف قصده الجنـائي إلى ارتكـاب جرائم إرهابية حتى ولو لم يتم تعيين تلك الجرائم على وجه التحديد. - يتعين أن يتمتع الأجنبي الأي صدر قرار بطرده من البلاد لعلاقته بتنظيم إرهابي بضمانة الـدعوى العادلـة، مـع التحفظ الخـاص بعدم الاطلاع على المعلومـات المتعلقة بـالأمن القومي، حيث يمكن التوفيق بين الحق في الدفاع في شكل المواجهة بالاليل مع اعتبارات المحافظة على الأمن القومي وذلك بتعيين محام له حق الاطلاع دون الثخص المقرر طرده، مع اطلاع القاضي نفسه عند الطعن في القرار الصادر بالطرد. - يجب أن تتبنى التشريعات المقارنة ما قررته المحكمة الأوربية لحقوق الإنسان من عدم جواز طرد الأجنبي إلى بلده (ولو كان إرهابيا) إذا كان من شأن ذلك أن يعرضه للتعذيب أو لمعاملة قاسية أو غير إنسانية. - نوصي بتعديل نص المادة (†) من قانون مكافحة الإرهاب في فقرته الثانية التي تنص على أنه "كما يعاقب بذات العقوبة المقررة للجريمة التامة كل من اتفق أو سـاعد بأيـة صورة على ارتكـاب الجرائم المشار إليها بـالفقرة الأولى من هذه المادة ولو لم تقع الجريمة بناء على ذلك الاتفاق أو تلك المساعدة". ذلك أن هذا النص يثوبه ـ في رأي ـ عدم الدستورية لإخلالهـ بمبدأ المسئولية الثخصية التي تقتضي أن يعاقب الثخص عن جريمة ارتكبها. وهنا الجريمة لم تقع، وكل ما فعله هو الاتفاق أو المساعدة. وبدلاً من ذلك كـان يمكن معاقبـة الشخص عن آن 
جريمة مستقلة وهي الاتفاق أو المساعدة على ارتكاب جريمة إرهابية حتى ولو لم تقع، وذلك على غرار الفقرة الأولى في شـأن التحريض.

- نوصي بتعديل نص المادة (V) من قانون مكافحة الإرهاب الذي ينص على أنـه

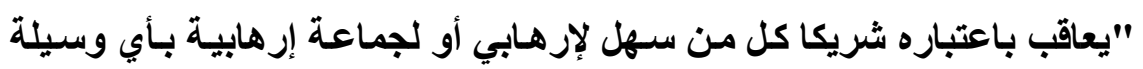

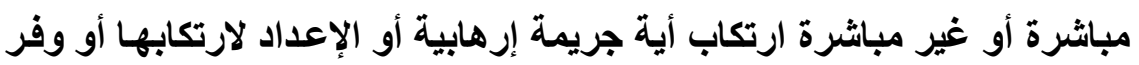

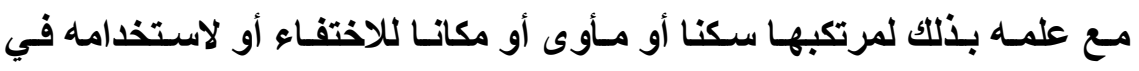
الاجتماعات أو غير ذلك من التسهيلات". وذلك لغموض النص حيث يحمل على ملى ملت الاعتقاد بأن الاشتراك اللاحق في شكل توفير سكن أو مـأوى أو مكانـاً للاختفـاء بعد وقوع الجريمة معاقب عليه بهذا الوصف. هذا النوع من الاشترالك اللاحق يخالف الاستور الذي ينص على مبدأ المسئولية الثخصية أي عن فعل ارتكبه نفس الـشخص ولـيس عـن فعل ارتكبـه شـخص غيـره. كمـا أن تـوفير وقـت لاستخدامه في الاجتماعـات ليس أمرا مفهومـا حيث لا يتضح علاقته بارتكاب

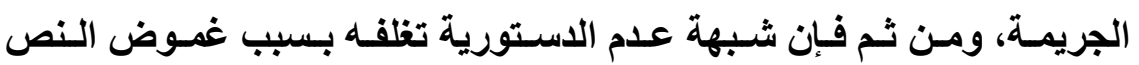
بالإضافة إلى إخلاله بمبدأ شخصية المسئولية.

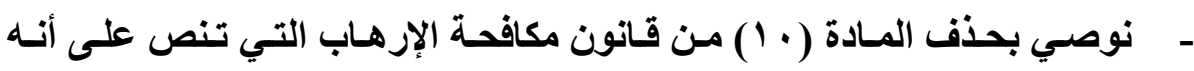
"استثناء من أحكام المادة (IV) من قانون العقوبـات لا يجوز النزول بالعقوبـة

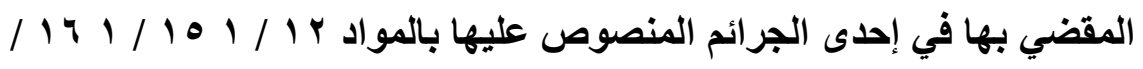

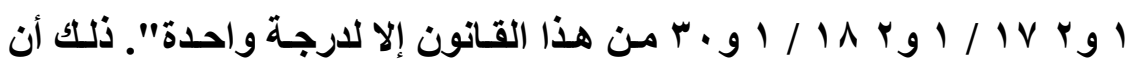
هذا يشكل مخالفـة لمبدأ الفصل بين السلطات حيث يتـخل المشرع في عمل القضاء بحرمسان القاضسي من تقدير ظروف المتهم وظروف القضية. والجدير بالملاحظـة أن تقدير القاضـي للعقوبـة مسن مظــاهر مبـدأ الشرعية في المـواد الجنائية وضمانة من ضمانات التقاضي. 


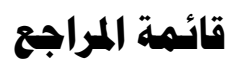

$$
\text { أو أولاً - هراجع باللغة العربية المراجع العاهة }
$$

ـ د. أحمد فتحي سرور، الوسيط في قانون الإجراءات الجنائية، دار النهضة العربية،

$$
.17
$$

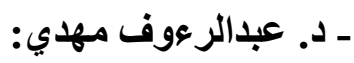

ـ شرح القواعد العامة للإجراءات الجنائية، دار النهضة العربية، 14 ـ بـ.

ـ شرح القواعد العامة لقانون العقوبات، دار النهضة العربية، 11 ـ ب.

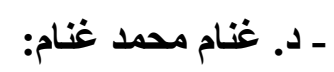

ـ الوجيز في شـرح قـانون الإجراءات الجنائيسة، مطبوعـات جامعة المنصورة،

$$
\text { .r... } 9
$$

ـ الوجيز في شرح قانون العقوبـات ـ القسم العام، مطبوعات جامعة المنصورة،

$$
\text { r... }
$$

ـ د. محمــ عيـــ الغريب، الـوجيز في الإجـراءات الجنائبـة، مطبوعـات جامعـة

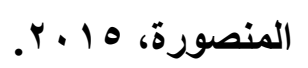




\section{(ب) - الأبحاث والرسائل}

ـ د. ذياب موسى البداينة، التنمية البشرية والإرهاب في الوطن العربي، بحث منشور بجامعة نايف العربية للطلوم الأمنية، الطبعة الأولى، ـ 1 + ؟.

ـ د. شريف بسيوني، الجريمة المنظمة عبر الوطنية ـ ماهيتها ووسائل مكافحتها دوليا

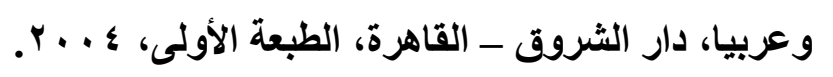

ـ د. شيماء عبدالغني عطالله، الحماية الجنائية للتعاملات الإكترونية ـ دراسـة مقارنـة

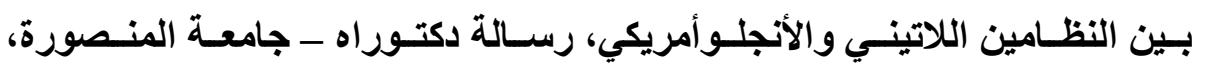

$$
\text { .r. . O }
$$

ـ د. طارق سرور، الاختصاص الجنائي العالمي، دار النهضة العربية، ؟ . . †. ـ د. عبدالتواب معوض الثوريجي، تعريف الجريمة الإرهابية، دار النهضة العربية،

$$
\text { r. } 1 \text {. }
$$

ـ د. فهد نشمي الخرينج الرشيدي، مفهوم المحاكمة العادلة في قضاء المحكمة الأوربية

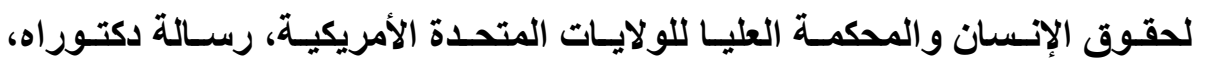

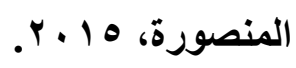

\section{(ب)- أحكام الحاكم الصرية والعربية

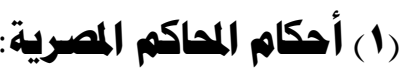

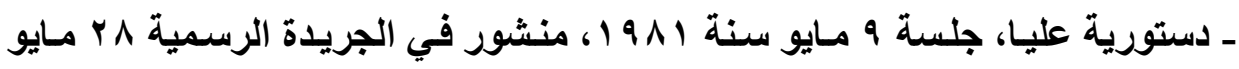

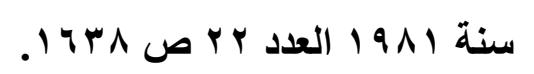

مجلتّ البحوث القانونيت والإقتصاديت ع 
ـ دستورية عليا، جلسة ب يونيه سنة 1 . . ب قضية رقم ؛ 1 ا لسنة اب قضائية.

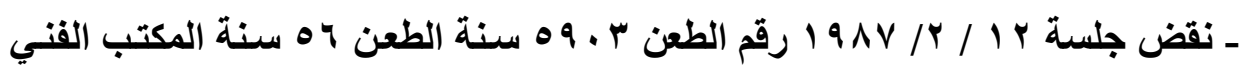
. $\mu$

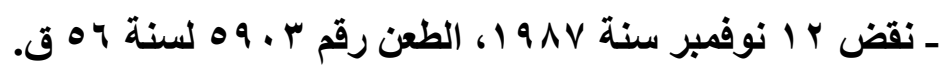

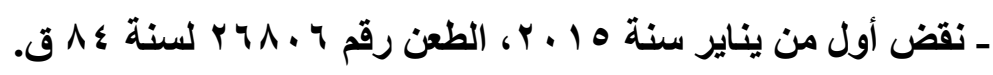

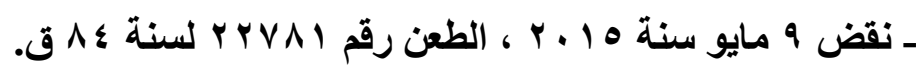

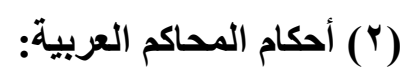

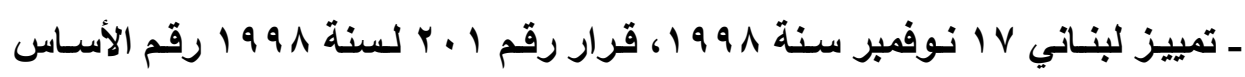

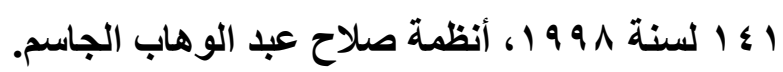

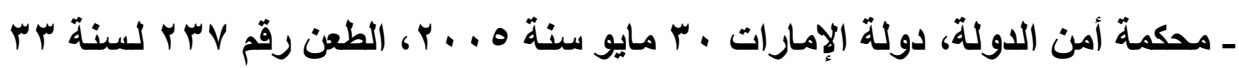

$$
\text { ق (أمن دولة). }
$$

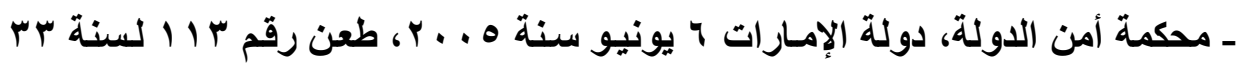

$$
\text { ق (أمن دولة). }
$$

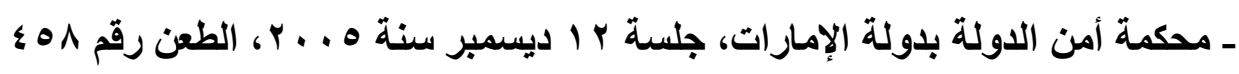
لسنة ع ؛ ق (أمن دولة). 
أ.د / شيماء عبد الغنى محمد عطا الله

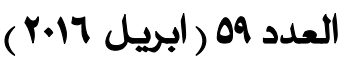

ثانياً - هراجع باللغة الأجنبية:

I- BIBLIOGRAPHIE EN FRANCAIS

\section{I- OUVRAGES GENERAUX, SPECIAUX ET THESES:}

- Carole Girault, Le droit pénal à l'épreuve de l'organisation criminelle, RSC 1998 p. 715.

- Céline Godeberge, Emmanuel Daoud, La loi du 13 novembre 2014 constitue-t-elle une atteinte à la liberté d'expression, De la nouvelle définition de la provocation aux actes de terrorisme et apologie de cesactes, AJ Pénal 2014 .

- C. Demunck, Rejet du pourvoi de la France contre la radiation de la People's Mojahedin Organization of Iran de la liste des organisations terrorists, CJUE, gdech., 21 déc. 2011, France c. People's Mojahedin Organization of Iran, aff. C$27 / 09$.

- Claude J. BERR, Blanchiment de capitaux et financement du terrorisme Répertoire de droit penal et de procedure pénale, janvier 2010 (dernière mise à jour : juin 2013)

- Francis Donnat, Un dirigeant terroriste ne peut pas bénéficier de la convention de Genève, JDA 2006 . 
أ.د/ شيماء عبد الغنى محمد عطا الله

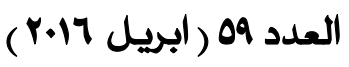

- Hélène Dumont, Actualités du droit pénal canadien, RSC 2008.

- Julie Alix, Réprimer la participation au terrorisme, RSC 2014.

- Julie Alix , Fallait-il étendre la compétence des jurisdictions pénales en matière terroriste ?, (à propos de l'article 2 de la loi $\mathrm{n}^{\circ}$ 2012-1432 du 21 décembre 2012 relative à la sécurité et à la lutte contre le terrorisme), Recueil Dalloz 2013 .

- Julien Cantegreil , La doctrine du « combatant ennemi illégal », RSC 2010.

-Mélanie Bombled, Terrorisme par association de malfaiteursencas de soutien à une organization terroriste, Dalloz actualité 03 juin 2014.

- Olivier Lecucq, Les notes des renseignements généraux peuvent fonder une decision d'expulsion, AJDA 2005 .

\section{2-ARRETS ET JUGEMENTS:}

- Crim. 23 avr. 1981, Bull. crim., n ${ }^{\circ}$ 116, cetteRevue, 1982, p. 609, obs. Vitu.

- Cour d'appel de Paris en date du 4 juillet 1988, n $^{\circ}$ 2507/88. 
- CE 31 juillet 1992, M. Duvalier, Lebon tables p. 985; Combarnous,La convention de Genève 50 ans après : bilan et perspectives, Publication de l'institut international des droits de l'homme, Bruylant, 2001),

- Crim. 30 avr. 1996, Bull. crim. $n^{\circ} 176$.

- Paris, $10^{\mathrm{e}}$ Ch., section B, 25 avr. 1997, n $^{\circ}$ 96/07152.

- Cour européenne des droits de l'homme (25 novembre 1997, Mehdi Zana c/ Turquie).

- CE 25 mars 1998, $M^{m e}$ Mahboub, Lebon tables p. 961.

- Paris, $10^{\mathrm{e}}$ Ch. Section A, 26 janv. 1999, 98/01582.

- Paris, $10^{\mathrm{e}}$ Ch., section A, 26 juin 2000, 00/00190

- Suresh c/ Canada (ministre de la Citoyenneté et de l'Immigration), [2002] 1 RCS 3

- Crim. 3 juin 2004, Bull. crim. n $^{\circ}$ 03-83.334.

- Conseil d'Etat, 04-10-2004, Quand les renseignements généraux convainquent le Conseil d'Etat, AJDA 2004 p. 1846

- Conseil d'Etat, 4 octobre 2004, Ministre de l'Intérieur, de la Sécurité intérieure et des Libertés locales c/ M. Bouziane (req. $n^{\circ}$ 266948) 
أ.د/ شيماء عبد الغنى محمد عطا الله

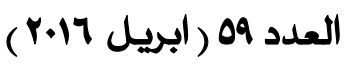

- Arrêt rendu par Conseil d'Etat, sect. cont., 04-10-2004, n $^{\circ}$ 266948 , Expulsion d'un imam soupçonné de liens avec des mouvements terrorists, Recueil Dalloz 2004 p. 2763.

- Charkaoui c/minister de la Citoyenneté et de l'Immigration et al. (2007) 1 RCS 350.

- Paris, $10^{\mathrm{e}}$ Ch. Section A, 19 nov. 2007, 07/01558.

- Cour de Justice de Communité Européanne, 3 sept. 2008, aff. C-402/05 P, Kadi et internationa Al Barakat Founation .

- CEDH, 2 oct. 2008, n 36109/03, Leroy c/ France, AJDA 2009. 872, chron. J.-F. Flauss ; RSC 2009. 124, obs. J. Francillon

- Cour Européenne des Droits de L'Homme, arrest Saadi c. Italie ([GC], $n^{\circ} 37201 / 06, \S \S 124-133$, CEDH 2008-...) et Daoudi c. France (n 19576/08, § 64, 3 décembre 2009).

- CEDH, 2 oct. 2008, n 36109/03, Leroy c/ France, AJDA 2009. 872, chron. J.-F. Flauss ; RSC 2009. 124, obs. J. Francillon

- COUR EUROPEENNE DES DROITS DE L'HOMME, $\left(2^{\text {ème }}\right.$ section)

Arrêt du 13 avril 2010 , Affaire Trabelsi c/ Italie , n 50163/08 
أ.د/ شيماء عبد الغنى محمد عطا الله

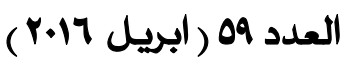

- COUR EUROPEENNE DES DROITS DE L'HOMME, Affaire H. R.c/ France $\left(5^{\text {ème }}\right.$ section),arrêt du 22 septembre 2011.

- CA Paris, Pôle 8, ch. 1, 22 févr. 2012, Juris-data $n^{\circ}$ 2012009372 ; le pourvoi formé contre cet arrêt a été rejeté par Crim., 10 avr. 2013, $\mathrm{n}^{\circ}$ 12-82.088, inédit.

- Crim. 10 avr. 2013, $\mathrm{n}^{\circ}$ 12-82.088.

- Caroline Fleuriot, CEDH, 30 mai 2013, Rafaa c. France, req. $n^{\circ} \mathbf{2 5 3 9 3 / 1 0}$, Expulsion d'un étranger lié à des organisations terroristes et risque de torture, Dalloz actualité 13 juin 2013.

- CJUE, gr. ch., 18 juill. 2013, aff. jtes C-584/10 P, C-593/10 P \& C-595/10 P

- Crim. 21 mai 2014 n$^{\circ}$ 13-83.758, Pierre de Combles de Nayves, Sauf en matière, AJ Pénal 2014 .

- Crim., 3 sept. 2014, n $^{\circ}$ 11-83.598, inédit ; O. Cahn, Procès équitable : la France tend à nouveau les verges à la Cour européenne des droits de l'homme, AJ pénal 2014. 577. 
أ.د / شيماء عبد الغنى محمد عطا الله

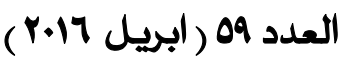

\section{I - REFERENCES IN ENGLISH}

\section{1 - BOOKS :}

- A Bianchi, 'Assessing the Effectiveness of the UN Security Council's Anti-terrorism Measures: The Quest for Legitimacy and Cohesion' (2006) 17 European Journal of International Law 881, 903-10.

- Andrew Lynch, Nicola McGarrityand George Williams*THE PROSCRIPTION OF TERRORIST ORGANISATIONS IN AUSTRALIA, 37 Fed. L. Rev. 1 2009, (Federal Law Review): www.heinonline.org.

- ANGUS JOHNSTON, FREEZING TERRORIST ASSETS AGAIN: WALKING A TIGHTROPE OVER THIN ICE?, 67 Cambridge L.J. 312008 : http://heinonline.org

- Christopher Michaelsen, The Proportionality Principle, Counter-terrorism Laws and Human Rights: A GermanAustralian, Comparison, 2 City U. H.K. L. Rev. 5 2010, p.19 :http://heinonline.org

- C Michaelsen, 'International Human Rights on Trial: The United Kingdom's and Australia's Legal Response to 9/11' (2003) 25 Syd LR 275 
أ.د/ شيماء عبد الغنى محمد عطا الله

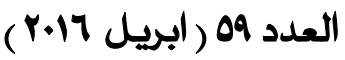

- DARAGH MURRAY, FREEDOM OF EXPRESSION, COUNTERTERRORISM AND THE INTERNET IN LIGHT OF THE UK TERRORIST ACT 2006 AND THE JURISPRUDENCE OF THE EUROPEAN COURT OF HUMAN RIGHTS, 27 Neth. Q. Hum. Rts. 331 2009( Netherlands Quarterly of Human Rights, Vol. 27/3 (2009).

- Dianne Otto ,PROTECTING HUMAN RIGHTS AND COUNTERING TERRORISM: AUSTRALIA'S CONTRADICTORY APPROACHES TO IMPLEMENTING ITS INTERNATIONAL LEGAL OBLIGATIONS, 44 VaI. U. L. Rev.( VALPARAISO UNIVERSITY LAW REVIEW [Vol.44) 911 2009-2010.

- G Kett-Straub, 'Data Screening of Muslim Sleepers Unconstitutional' (2006) 7 German LJ 967.

- GL Neuman, 'The Extraterritorial Constitution after Boumediene v Bush' (2009) 82 Southern California Law Review 259.

- G. Roma, "Interesting Times for International Humanitarian Law: challenges from the 'War on Terror"', 27 Fletcher Forum of World Affairs (2003).

- ILIAS BANTEKAS, SUSAN NASH, \& MARK MACKAREL, INTERNATIONAL CRIMINAL LAw 229 (2001). 
أ.د/ شيماء عبد الغنى محمد عطا الله

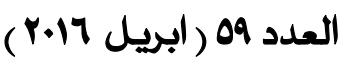

- JOHN A.E. VERVAELE, THE ANTI-TERRORIST LEGISLATION IN THE US: CRIMINAL LAW FOR THE ENEMIES, 1 Inter-Am. \& Eur. Hum. Rts. J. 52008.

- JOO-CHEONG THAM, POSSIBLE CONSTITUTIONAL OBJECTIONS TO THE POWERS TO BAN 'TERRORIST' ORGANISATIONS, 27 U.N.S.W.L.J. (UNSW Law Journal) 4822004.

- Justin N. B. Frank and Javaid Rehman, Assessing the Legality of the Attacks by the International Coalition against Terrorism against Al-Qaeda and the Taliban in Afghanistan: An Inquiry into the Self-Defence Argument under Article 51 of the UN Charter $67 \mathrm{~J}$. Crim. L.( le Journal of Criminal Law) 4152003.

- Konrad Lachmayer, Constitutional and Anti-Constitutional Responses to Terrorism: The Difficulty of Removing Exclusions from Constitutional Law, 2 City U. H.K. L. Rev. 5 2010 , p. 5 : http://heinonline.org

- L.M. Ivey, "Comment: Ready, aim, fire? The President's executive order authorizing detention, treatment, and trial of certain non-citizens in the war against terrorism is a powerful 
أ.د/ شيماء عبد الغنى محمد عطا الله

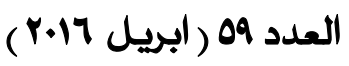

weapon, but should it be upheld?", 33 Cumberland Law Review (2002-2003).

- MICAH Wyatt , DESIGNATING TERRORIST ORGANIZATIONS:DUE PROCESS OVERDUE, 39 Golden Gate U. L. Rev. 221 2008-2009: http://heinonline.org

- ODED LOWENHEIM, Transnational criminal organizations and security The case against inflating the threat, 57 Int'l J(INTERNATIONAL JOURNAL). 513 2001-2002, p.513: http://heinonline.org

- OSCAR Roos, BENJAMIN HAYWARD \& JOHN MORSS, Beyond the Separation of Powers: Judicial Review and the Regulatory, Proscription of Terrorist Organisations, 35 U.W. Austl. L. Rev. 81 2010-2011, http//Heinonline.org

- Till Gut, German Federal Court of Justice (Bundes gerichts hof-BGH), 3rd Criminal Senate, Promoting a Terrorist Organisation: Support versus Recruitment of Members or Supporters, Decision of 16 May 2007, Case No. AK 6/07 and StB 3/07, 71 J. Crim. L. 491 2006-2007, 71 J. Crim. L. 491 2006-2007, www.heinonline.org

\section{2- DECISIONS OF COURTS :}


أ.د/ شيماء عبد الغنى محمد عطا الله

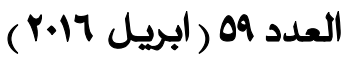

- YickWo v. Hopkins, 118 U.S. 356, 369 (1886).

- Ex parte Quirin 317 US 1 (1942)

- U.S. Supreme Court C. \& S. Air Lines, Inc. v. Waterman S.S. Corp., 333 U.S. 103 (1948) Chicago \& Southern Air Lines, Inc. v. Waterman Steamship Corp. No. 78, 333 U.S. 103

- Johnson v. Eisentrager, 339 US 763 (1950).

- Jo hnson v. Eisentrager, 339 U.S. 763, 777-78 (1950).

- Australian Communist Party v Commonwealth

83 CLR 1, https://en.wikipedia.org/wiki/Australian_Communist_Party_v_C ommonwealth.

- Kwong Hai Chew v.Colding, 344 U.S. 590,596 n.5 (1953).

- Draper v. US, 358 U.S. 307 (1959).

- U.S. Supreme Court, Scales v. United States, 367 U.S. 203 (1961)

- Case 24/62 Germany v. Commission [1963] ECR 63, 69.

- Sardino v. Federal Reserve Bank of N.Y., 361 F.2d 106, 111 (1966).

ع V 
أ.د/ شيماء عبد الغنى محمد عطا الله

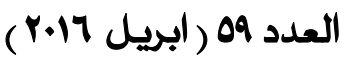

- Katz v. US, 389 US 347 (1967).

- Berger v. New York, 388 US 41 (1967).

- Healy v. James, 408 U.S. 169, 182-83, 92 S.Ct. 2338, 33 L.Ed.2d 266 (1972)

- US v. US District Court (Keith), 407 US 297 (1972).

- Morrissey v. Brewer, 408 U.S. 471 (1972).

- Gagnon v. Scarpelli, 411 U.S. 778 (1973).

- G irard v. Klopfenstein, 930 F.2d 738, 742 (9th Cir. 1991);

Withrow v. Larkin, 421 U.S. 35, 46 (1975).

- Buckley v. Valeo, 424 U.S. 1, 96 S.Ct. 612, 46 L.Ed.2d 659 (1976).

- M athews v. Eldridge, 424 U.S. 319, 334 (1976).

- European Court of Human Rights, Handysidevs the UK, 7 December 1976, Application No. 5493/72,

- Hoffman Estates v. The Flipside, Hoffman Estates 455 U.S. 489 (1982).

- First National City Bank v. Banco Para El Comercio Exterior de Cuba, 462 U.S. 611, 103 S.Ct. 2591, 77 L.Ed.2d 46 (1983)

مجلت البحوث القانونيت والإقتصاديت 
أ.د/ شيماء عبد الغنى محمد عطا الله

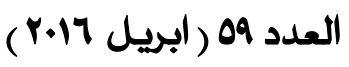

- Osborne v. Ohio, 495 U.S. 103, 119-22, 110 S.Ct. 1691, 109 L.Ed.2d 98 (1990).

- Walker v. City of Berkeley, 951 F.2d 182, 184 (9th Cir. 1991)

- Brown v. State Bd. of Dental Examiners, No. 93A-1-017, 1994 WL 315304 (Del. Super.Ct. May 23, 1994)

- Lange v Australian Broadcasting Corporation (1997) 189 CLR 520.

- European Court of Human Rights, Zana vs Turkey, 25 November 1997, Application No.69/1996/688/880, Reports 1997-VII.

- European Court of Human Rights, Surek vs Turkey (No. 1), 8 July 1999, Application No. 26682/95, Reports 1999-IV.

- United States Court of Appeals, District of Columbia Circuit., PEOPLE'S MOJAHEDIN ORGANIZATION OF IRAN, Petitioner,v. UNITED STATES DEPARTMENT OF STATE and Madeleine K. Albright, Secretary of State, Respondents. Liberation Tigers of Tamil Eelam, Petitioner,v.United States Department of State, Respondent (1999),182 F.3d 17, 337 U.S.App.D.C. 106. 
أ.د/ شيماء عبد الغنى محمد عطا الله

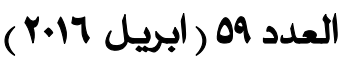

- People's Mojahedin Org. of Iran v. U.S. Dep't of State ("PMO"'), 182 F.3d 17, 18-19 (D.C. Cir. 1999).

- European Court of Human Rights, CASE OF ÖZTÜRK v. TURKEY , 28 September 1999.

- Nixon v. Shrink Missouri Gov't PAC, 528 U.S. 377, 120 S.Ct. 897, 145 L.Ed.2d 886 (2000)

- Dusenbery v. United States 534 U.S. 161 (2002).

- McConnell v. Fed'l Election Comm'n, 540 U.S. 93, 124 S.Ct. 619, 157 L.Ed.2d 491 (2003)

- Cableuropa and Others v Commission [2003] ECR 11-4251, paragraph 225)

- Hamdi v. Rumsfeld, 316 F.3d 450 (4 thCir. 2003);Westlaw, 2004 WI 1431951 (US).

- United States Court of Appeals, District of Columbia Circuit, NATIONAL COUNCIL OF RESISTANCE OF IRAN, Petitioner,v. DEPARTMENT OF STATE and Colin L. Powell, Secretary of State, Respondents (2004), F373 F.3d 152:

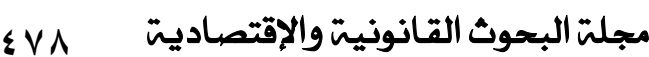


أ.د/ شيماء عبد الغنى محمد عطا الله

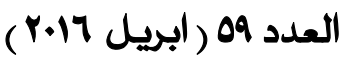

- United States Court of Appeals, District of Columbia Circuit, NATIONAL COUNCIL OF RESISTANCE OF IRAN, Petitioner,v. DEPARTMENT OF STATE and Colin L. Powell, Secretary of State, Respondents, 2004, F373 F.3d 152:

- Singh-Kaur v. Ashcroft, 385 F.3d 293, 301 (3d Cir. 2004).

- Hamdi v. Rumsfeld, 124 S.Ct. 2633 (2004).

- Rumsfeld v. Padilla, 124 S.Ct. 2711 (2004).

- Rasul v. Bush ,542 US 466 (2004).

- Case C-400/99 Italy v. Commission [2005] ECR 1-3657, paragraph 22.

- U.S. v. Afshari, 426 F.3d 1150 (9th Cir. 2005)

- Court of Cassation, Section II Criminal (Corte di Cassazione, Sezione II Penale, Judgment No. 24994 of 25 May 2006, 71 J. Crim. L. 147 2006-2007.

- Eckes, Christina, Case T-228/02, Organisation des Modjahedines du Peupled'Iran v. Council and UK (OMPI), Judgment of the Court of First Instance (Second Chamber) of 
أ.د/ شيماء عبد الغنى محمد عطا الله

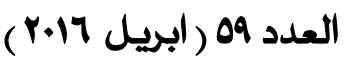

12 December 2006 [case], Common Market Law Review, Vol. 44, Issue 4 (August 2007), pp. 1117-1130

- Regina v. Lodhi SARAH SORIAL, : 32 Alternative L.J. 160 2007.

- Michele Nino, Court of Cassation, Section II Criminal (Corte di Cassazione, Sezione II Penale).

- International Terrorism: Definition, Judgment No. 24994 of 25 May 2006, 71 J. Crim. L. 147 2006-2007.

- Organisation des Modjahedines du peupled'Iran V Council of the European Union, Judgment of the Court of First Instance (Second Chamber), 12 December 2006 II - 4674 , Case T228/02, 2006-1112 A E.C.R. II-4665 2006.

- Hamdan v Rumsfeld 548 US 557 (2006)

- (Cases T- 110, 150 and 405/03, judgment of 26 April 2006) and the European Court of Justice (ECJ) (Case C-266/05 P, judgment of 1 February 2007): BRIAN SLOAN, FREEZING TERRORIST ASSETS AGAIN: WALKING A TIGHTROPE OVER THIN ICE?, 67 Cambridge L.J. 31 2008: http://heinonline.org 
أ.د/ شيماء عبد الغنى محمد عطا الله

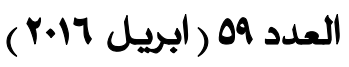

- Decision 26 Juin 2006: 71 J. Crim. L. 147 2006-2007.

- Humanitarian Law Project v. Mukasey, 509 F.3d 1122, 113033 (9th Cir. 2007).

-Charkaoui v. Minister of Citizenship and Immigration, (2007) SCC

http://www.shk.ca/docs/CharkaouiMinsterCitizenshipandIm migration.pdf

- Leghaei v Director-General of Security [2007] HCA Trans 655.

- Charkaoui v. Minister of Citizenship and Immigration, (2007) SCC 9.

- Supreme Court of Canada decision, Charkaoui v. Minister of Citizenship and Immigration, 2007 SCC 9.

- Boumediene v. Bush 553 US (2008)

- Joined Cases C-402/05 P and C-415/05 P Kadi and Al Barakaat International Foundation v Council (ECJ 3September 2008) 283-284.

- 18 U.S.C. § 2339B (2009).

- 18 U.S.C. § 11115558 (b)(2)(A)(v)(2009) 
أ.د / شيماء عبد الغنى محمد عطا الله

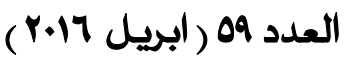

- Kiyemba v. Obama 18 févr. 2009, Circuit docket 08-5424.

- HOLDER, ATTORNEY GENERAL, ET AL. v. HUMANI;

TARIAN LAW PROJECT ET AL. ,561 US. 2010 . June 21, 2010 , No. 08-1498.

- Scales v. United States, 367 U.S. 203

- Dennis v. United States, 341 U. S. 494, 341 U. S. 499-500,

- Yates v. United States, 354 U. S. 298.

- Withrow, 421 U.S.58

- 68 Stat. 775, 50 U.S.C 841

ثالثاً - هواقع الإنترنت

- https://www.ag.gov.au/nationalsecurity/counterterrorismlaw

- www.bverfg.de/entscheidungen/rs20050718_2bvr223604

- http://www.cc.gov.eg/

- www.dalloz.fr/documentation/Document?id

- https://en.wikipedia.org/wiki/communist_Control

- http://www.gesetze-im-internet.de/englisch_stgb/englisch

- http://www.hamdanvrumsfeld.com/05-184.pdf, 548 US 557

مجلت البحوث القانونيت والإقتصاديت 
أ.د/ شيماء عبد الغنى محمد عطا الله

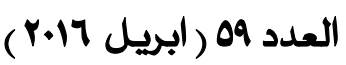

- http://heinonline.org •

- https://www.law.cornell.edu/uscode/text/18/2339B

- http://www.legislation.gov.uk/ukpga/2000/11/contents

-http://news.findlaw.com/hdocs/docs/terrorism/

-http://njlaw.rutgers.edu/collections/resource.org

-http://www.shk.ca/docs/CharkaouiMinsterCitizenship/

- https://supreme.justia.com/cases/federal/us/561/08-1498/

- http://www.supremecourtus.gov/opinions/03pdf/03-334.pdf

- http://uniset.ca/other/cs5/182F3d17.html 